Northwestern University School of Law Northwestern University School of Law Scholarly Commons

Faculty Working Papers

2012

\title{
Religion and the Equal Protection Clause
}

Steven G. Calabresi

Northwestern University School of Law, s-calabresi@law.northwestern.edu

Abe Salander

\section{Repository Citation}

Calabresi, Steven G. and Salander, Abe, "Religion and the Equal Protection Clause" (2012). Faculty Working Papers. Paper 213.

http://scholarlycommons.law.northwestern.edu/facultyworkingpapers/213 


\section{RELIGION AND THE EQUAL PROTECTION CLAUSE}

By Steven G. Calabresi ${ }^{1}$ and Abe Salander ${ }^{2}$

INTRODUCTION............................................................................................................................. 2

I. THE ORIGINAL MEANING OF THE FOURTEENTH AMENDMENT ........................ 13

A. THE TeXT AND STRUCTURE OF THE FOURTEENTH AMENDMENT ………………..............................

B. THE FOURTEENTH AMENDMENT'S BAN ON CASTE AND CLASS LEGISLATION.......................................29

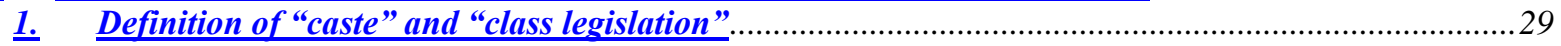

$\underline{2 .} \quad$ Historical evidence of opposition to class legislation …….......................................................................

II. RELIGION AND THE FOURTEENTH AMENDMENT .................................................. 60

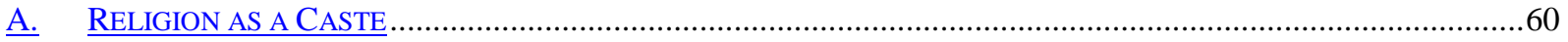

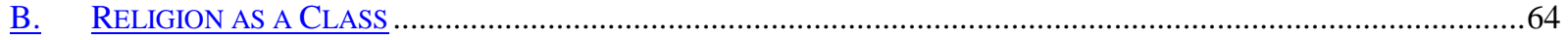

C. THE FOURTEENTH AMENDMENT AUTOMATICALLY PROTECTS GROUPS WITH POLITICAL RIGHTS...................70

D. HISTORY OF RELIGIOUS EQUALITY IN AMERICA ………..........................................................................76

1. Historical persecution of religion and the founders' response .............................................................78

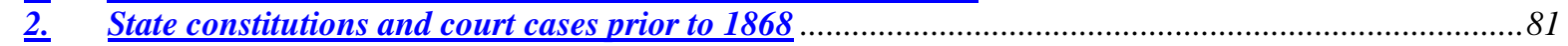

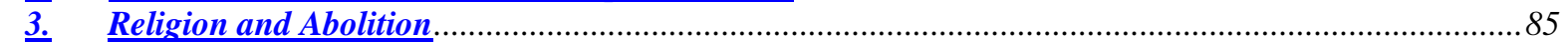

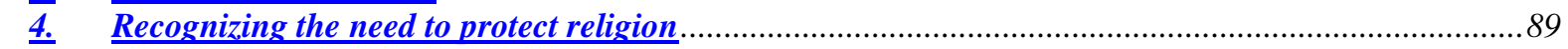

E. FOREIGN CONSTITUTIONS AND LAWS GUARANTEEING EQUALITY ………….............................................95

III. CLASS LEGISLATION AND MODERN CASE LAW ……............................................... 98

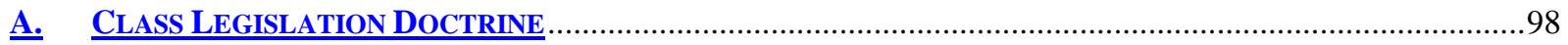

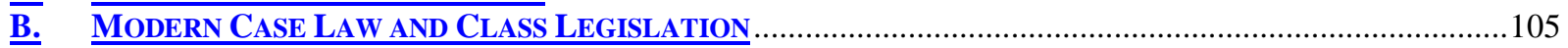

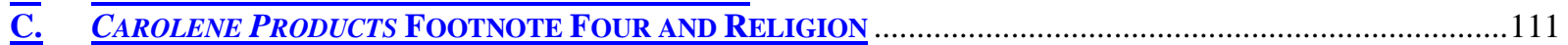

IV. THE FREE EXERCISE AND ESTABLISHMENT CLAUSES AFTER THE FOURTEENTH AMENDMENT ........................................................................................................ 118

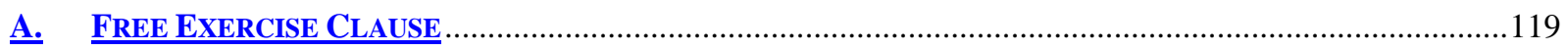

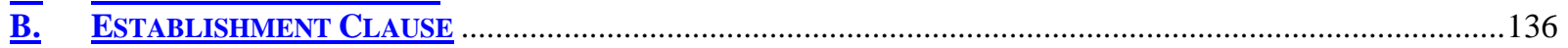

V. THE BLAINE AMENDMENTS ............................................................................................. 146

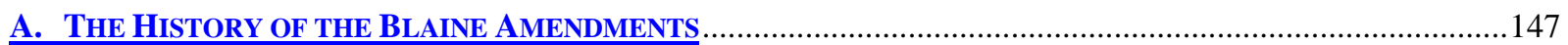

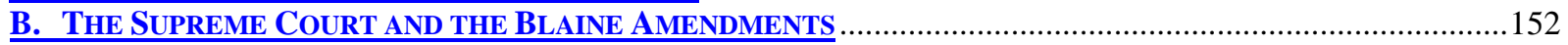

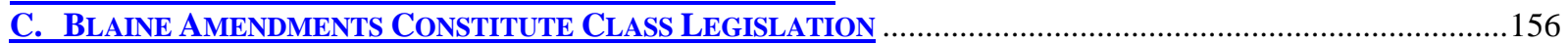

D. THE COUNTERARGUMENT OF THE BLAINE AMENDMENTS

VI. THE PUBLIC SCHOOL SYSTEM .................................................................................... 162

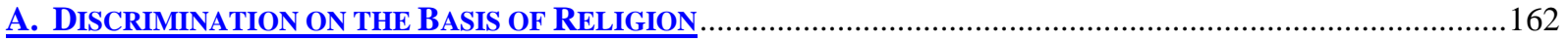

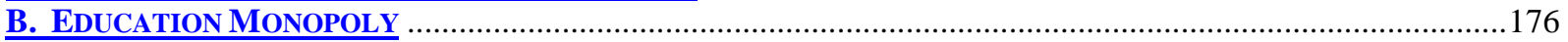

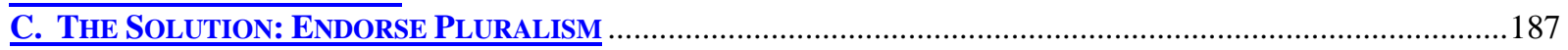

CONCLUSION …….......................................................................................................................... 192

1 Class of 1940 Research Professor of Law, Northwestern University. Copyright 2012 - all rights reserved.

2 JD 2012 Northwestern University School of Law. We dedicate this article to Professors Michael W. McConnell and Akhil Reed Amar from both of whom we have learned so much about religious liberty. We would like to thank Stephen Presser for his helpful suggestions and comments and our research librarian Pegeen Bassett for her enormous help with this project. 
Statement of the Supreme Court in 1895:

"Whenever a distinction is made in the burdens a law imposes or in the benefits it confers on any citizens by reason of their birth, or wealth, or religion, it is class legislation, and leads inevitably to oppression and abuses, and to general unrest and disturbance in society. It was hoped and believed that the great amendments to the Constitution which followed the late civil war had rendered such legislation impossible for all future time."

Pollock v. Farmers' Loan \& Trust Co. ${ }^{3}$

\section{Introduction}

Ask anyone whether the Constitution permits discrimination on the basis of religion, and the response will undoubtedly be no. Yet the modern Supreme Court has not recognized that the anti-discrimination command of the Fourteenth Amendment protects religion in the same way that the Amendment protects against discrimination on the basis of race or gender. In fact, the Supreme Court has permitted the legislature to facially discriminate against religion in funding programs. ${ }^{4}$ To make matters worse, thirty-seven state constitutions and the District of Columbia's Code openly discriminate on the basis of religion in so-called Blaine amendments. ${ }^{5}$

The exclusion of religion from the Fourteenth Amendment's anti-discrimination command is all the more remarkable because the Supreme Court has used the Amendment's antidiscrimination command to protect a wide variety of groups - most of whom are never mentioned elsewhere in the text of the Constitution. The Supreme Court has relied on the Amendment's anti-discrimination command to strike down classifications based on gender, ${ }^{6}$

\footnotetext{
${ }^{3} 157$ U.S. 429, 596, (1895) superseded by constitutional amendment, CONST. AMEND. XVI, as recognized in South Carolina v. Baker, 485 U.S. 505 (1988).

${ }^{4}$ See Locke v. Davey, 540 U.S. 712 (2004) (permitting a state to withhold scholarship money from individuals seeking a religious education, even though it provided scholarships to individuals seeking a secular education).

${ }^{5}$ Kyle Duncan, Comment, Secularism's Laws: State Blaine Amendments and Religious Persecution, 72 Fordham L. Rev. 493 (2003) (counting so-called "Blaine Amendments"); D.C. CODE § 44-715 (2012).

${ }^{6}$ Craig v. Boren , 429 U.S. 190 (1976); Frontiero v. Richardson, 411 U.S. 677 (1973); United States v. Virginia (The VMI Case), 518 U.S. 515 (1996).
} 
illegitimacy, ${ }^{7}$ physical disability, ${ }^{8}$ alienage,${ }^{9}$ citizenship,${ }^{10}$ and sexual orientation. ${ }^{11}$ And in

Skinner v. State of Oklahoma, the Supreme Court used the Fourteenth Amendment's anti-

discrimination command to strike down a statute compelling sterilization for larceny but not embezzlement. ${ }^{12}$ Although the Supreme Court once restricted its equal protection doctrine to "discrete and insular minorities,"13 it has recently extended equal protection rights to whites, limiting affirmative action programs and other efforts to aid racial minorities. ${ }^{14}$ Most recently, the Ninth Circuit used the Fourteenth Amendment's anti-discrimination command to strike down California's Proposition 8, banning same-sex marriages. ${ }^{15}$ Curiously, the Supreme Court has not granted the same anti-discrimination protection to religion despite explicit suggestions in the text of the Constitution itself that religion ought to always be treated as a suspect class.

We think this outcome is clearly wrong. The Supreme Court's current view is that the framers of the Fourteenth Amendment granted equal protection to groups that lacked civil or political rights in 1787 (racial minorities), as well as to groups that lacked civil and political rights in 1787 and 1868 but who would gain those rights in the future (e.g., women, immigrants, gays and lesbians), yet the Fourteenth Amendment denied equal protection to groups that did

${ }^{7}$ Weber v. Aetna Casualty \& Surety Co., 406 U.S. 164 (1972); Gomez v. Perez, 409 U.S. 535 (1973); Trimble v. Gordon, 430 U.S. 762 (1977).

${ }^{8}$ City of Cleburne v. Cleburne Living Center, Inc., 473 U.S. 432 (1985) (holding that denial of zoning permit to home for mentally retarded individuals failed rational basis test under the Equal Protection Clause); but see Id. (Marshall, J., dissenting in part and concurring in the judgment) (arguing that mentally retarded individuals should be considered a suspect class due to history of discrimination and strict scrutiny analysis should apply).

${ }^{9}$ Plyler v. Doe, 457 U.S. 202 (1982) (holding that a school district could not charge children of illegal immigrants tuition to compensate for lost state funding).

${ }^{10}$ In re Griffiths, 413 U.S. 717 (1973) (holding that a state could not condition admission to the bar on citizenship).

${ }^{11}$ Romer v. Evans, 517 U.S. 620 (1996); see also Lawrence v. Texas, 539 U.S. 558 (2003) (O’Connor, J. concurring).

12 Skinner v. State of Oklahoma, ex. rel. Williamson, 316 U.S. 535 (1942). See also Harper v. West Virginia, 383 U.S. 663 (1966) (striking down a poll tax under the equal protection clause).

${ }^{13}$ United States v. Carolene Products Co., 304 U.S. 144, 155 n.4 (1938).

${ }^{14}$ See, e.g., Gratz v. Bollinger, 539 U.S. 244 (2003); Parents Involved in Cmty. Sch. v. Seattle Sch. Dist. No. 1, 551 U.S. 701 (2007); Ricci v. DeStefano, 129 S. Ct. 2658 (2009).

${ }^{15}$ See Perry v. Brown, 591 F.3d 1147 (9 ${ }^{\text {th }}$ Cir. 2010). 
have both civil and political rights in both 1787 and 1868 (religious groups). Such an outcome is quite frankly wrong. A more likely construction of the Fourteenth Amendment is that it did guarantee equal protection for groups that already had civil and political rights prior to 1868 , as well as to other groups newly-recognized for protection starting in 1868. Thus, Michael A. Paulsen has quite rightly argued for an equal protection approach to the Establishment Clause, ${ }^{16}$ and Bernadette Meyler has argued quite rightly for an equal protection approach to the Free Exercise Clause. ${ }^{17}$ Other scholars as well have sought to interpret the two Religion Clauses of the First Amendment with reference to the Equal Protection Clause. ${ }^{18}$ But no one to date has made an argument from the original public meaning of the text of the Fourteenth Amendment that the anti-discrimination command of that Amendment bans all forms of discrimination on the basis of religion, including Blaine Amendments and public school monopolies, and that it would do so even if the Establishment Clause and Free Exercise Clauses had never been adopted!

In this article, we argue that, as a matter of original meaning, the Fourteenth Amendment, standing alone, forbids all discrimination on the basis of religion just as it forbids all discrimination on the basis of race and gender. Our understanding of the Fourteenth Amendment is based on the research of Professor Melissa Saunders ${ }^{19}$ and Professor John Harrison, ${ }^{20}$ who

\footnotetext{
${ }^{16}$ Michael A. Paulsen, Religion, Equality, and the Constitution: An Equal Protection Approach to Establishment Clause Adjudication, 61 Notre Dame L. Rev. 311 (1986).

${ }^{17}$ Bernadette Meyler, The Equal Protection of Free Exercise: Two Approaches and their History, 47 Boston College L. Rev. 274 (2006).

${ }^{18}$ Other scholars have also argued that the religion clauses involve a concept of equality. See, e.g., Philip B. Kurland, Of Church and State and the Supreme Court, 29 U. Chi. L. Rev. 1 (1961) (stating that the religion clauses should be "read together as creating a doctrine more akin to the reading of the equal protection clause than to the due process clause"); Phillip HAMBURGer, SEPARATION OF ChURCH AND STATE (2002); Susan Gellman \& Susan Looper-Friedman, Thou Shalt Use the Equal Protection Clause for Religion Cases (Not Just the Establishment Clause), 10 U. Pa. J. Const. L. 665 (2008); Christopher L. EISGRuber \& LAWrence G. SAGER, Religious FREEDOM AND THE CONSTITUTION 70 (2007) (explaining that "the religion clauses express equality norms that ... are much like the more general norms in the Equal Protection Clause").

${ }^{19}$ Melissa L. Saunders, Equal Protection, Class Legislation, and Colorblindness, 96 Mich. L. Rev. 245 (1997).

${ }^{20}$ John Harrison, Reconstructing the Privileges or Immunities Clause, 101 Yale L. J. 1385 (1992).
} 
have both argued that the Amendment outlawed class legislation, and on the research of Professor Steven Calabresi and Julia Rickert, who have argued that the Amendment also banned systems of caste. ${ }^{21}$ The historical evidence is overwhelming and persuasive. We argue that a ban on class legislation and systems of caste is broad in scope and that it includes a ban on all forms of discrimination on the basis of religion. Religion is a suspect classification such that discrimination on the basis of religion ought always to be subjected to strict scrutiny which is strict in theory and fatal in fact. We reach this conclusion without regard to the original meaning of either the Establishment Clause or of the Free Exercise either in 1791 or in 1868.

The anti-discrimination command of the Fourteenth Amendment would ban discrimination on the basis of religion even if the Fourteenth Amendment did not incorporate the Establishment and Free Exercise Clauses. Discrimination on the basis of religion is a forbidden form of class legislation even when it is sanctioned in State constitutions, and it is always unconstitutional. And just as the constitutional and statutory bans on race discrimination and on sex discrimination ban State laws and workplaces and educational environment that are hostile to African Americans or to women, the ban on religion discrimination, which is specifically mentioned in the Civil Rights Act of 1964, ought to be understood to ban community or work or school environments that are hostile to religion. A learning environment in which student religious groups face official hostility on account of their religious beliefs is quite simply illegal. The Supreme Court's recent 5 to 4 ruling in Christian Legal Society v. Martinez, where a Christian Legal Society chapter was compelled to admit members who engaged in gay sexual relationships, is thus wrongly decided and should be overruled as a violation of the federal Civil

\footnotetext{
${ }^{21}$ Steven G. Calabresi \& Julia T. Rickert, Originalism and Sex Discrimination, 90 Tex. L. Rev. 1 (2011). See also Mark C. Yudof, Equal Protection, Class Legislation, and Sex Discrimination: One Small Cheer for Mr. Herbert Spencer's Social Statics, 88 Mich. L. Rev. 1366 (1990) (arguing that the Equal Protection Clause banned systems of class and caste).
} 
Rights laws and of the Fourteenth Amendment. ${ }^{22}$ Moreover, Supreme Court decisions that seek to scrub the public square clean of all references to religion are themselves unconstitutional attempts to create a public environment that is hostile to religion. ${ }^{23}$ A Supreme Court rule banning public displays on government buildings of, for example, the Ten Commandments creates an environment that is hostile to religion in the same way that a Supreme Court rule banning displays of pictures of Martin Luther King or of Susan B. Anthony would create an environment that is hostile to African Americans or to women.

Our anti-discrimination argument with respect to religion is in line with the Supreme Court's most important and most recent decision protecting religious liberty from government action. In its 2012 decision in Hosanna-Tabor Evangelical Lutheran Church v. EEOC, a unanimous Supreme Court recognized that the Constitution mandates a "ministerial exception" to generally applicable employment laws. ${ }^{24}$ In the Hosanna-Tabor decision, a minister of a church claimed that she had been wrongfully terminated in violation of Title VII of the Civil Rights Act of $1964 .^{25}$ The Supreme Court unanimously held that the plaintiff was a minister, and the Court explicitly rejected the Obama Administration's argument that the government can subject ministers in churches to the employment discrimination requirements of Title VII. ${ }^{26}$ Hosanna-Tabor thus requires the government to consider the impact of its neutral, generally applicable employment discrimination laws on religion. Since those employment discrimination laws make it just as illegal to discriminate on the basis of religion, as it is to discriminate on the basis of race or sex, it is hard to see how a religious employer could ever be stopped from firing

\footnotetext{
${ }^{22} 130$ S. Ct. 2971 (2010).

${ }^{23}$ See, e.g., Lee v. Wesiman, 505 U.S. 577 (1992) (striking down school prayers at graduation ceremonies); McCreary County v. ACLU of Kentucky, 545 U.S. 844 (2005) (outlawing a display of the Ten Commandments).

24132 S. Ct. 694 (2012).

${ }^{25}$ Id. at $699-701$.

${ }^{26} \mathrm{Id}$. at $706-707$.
} 
any employee for religious reasons whether that employee is or is not a minister. Obviously, religious employers can hire exclusively members of their own religions just as it is obvious that Native American tribes can decide whether a person is or is not, for example, a Cherokee, and just as men can be excluded from all women's colleges that have federal tax exempt status. The Hosanna-Tabor decision decisively rejects the claim that forbidding discrimination on the basis of race or sex discrimination under the Constitution is somehow more important under the Constitution and laws than is forbidding discrimination on the basis of religion. All three forms of discrimination are equally proscribed by the Constitution and by our civil rights laws.

Our analysis begins with the premise that the proper way to interpret the Constitution is to evaluate the original public meaning of the Constitution's text. ${ }^{27} \mathrm{We}$ thus follow the methodology of Supreme Court justices Antonin Scalia ${ }^{28}$ and Clarence Thomas throughout this article. In looking for the objective original public meaning of the Fourteenth Amendment's antidiscrimination command, we have looked at dictionaries, speeches, newspaper articles, documents, legislative histories, and historical events to determine the original public meaning of the constitutional text. ${ }^{29}$ We emphatically do not think that the framers' subjective meaning or intent is a controlling analytical factor, just as a party's subjective intent in signing a contract does not determine the meaning of the contract. ${ }^{30}$ Instead, we think that what matters is the objective public meaning of the text as defined during the historical time period in which it was

\footnotetext{
27 See generally ANTONIn SCALIA, A MATTER OF INTERPRETATION: FEDERAL COURTS AND THE LAW (1997). ${ }^{28}$ Id.

${ }^{29}$ See William Michael Treanor, Taxing Text Too Seriously: Modern Textualism, Original Meaning, and the Case of Amar's Bill of Rights, 106 MiCH. L. REV. 487, 497-98 (2007).

30 See Robert H. Bork, The Tempting of AMERICA: The POLITICAL SEDUCTION OF THE LAw 144 (1990) (“The search is not for a subjective intention.... [W] hat counts is what the public understood."); John Harrison, State Sovereign Immunity and Congress's Enforcement Powers, 2006 Sup. Ct. Rev. 353, 388 (2006) (discussing how the framers of the Fourteenth Amendment were concerned that the Amendment could have broader implications than they expected or intended); Steven Calabresi \& Andrea Matthews, Originalism and Loving v. Virgina, Rev.____ (forthcoming 2012) (on file with authors) (arguing that the Fourteenth Amendment banned antimiscegenation laws, even though the framers subjectively intended otherwise).
} 
written and ratified. ${ }^{31}$ It is therefore necessary to examine the historical record to discern how the framers understood the Fourteenth Amendment's meaning in so far as it bans discrimination.

Adhering to the original public meaning of the text is especially important when evaluating a Fourteenth Amendment question. If a court takes the view that the Fourteenth Amendment's guarantee of equal civil rights can change and evolve over time, then no one is safe. Living constitutionalists must concede that not only could groups be added into the Fourteenth Amendment's protection, but also that groups could be removed from the Fourteenth Amendment's protection as well. ${ }^{32}$ This consequence was implicitly endorsed by the Warren Court in Harper v. Virginia State Board of Elections, in which the majority stated, "the Equal Protection Clause is not shackled to the political theory of a particular era . . we have never been confined to historic notions of equality." 33 But perhaps some kinds of shackling are in fact good. If the Supreme Court would always agree to adhere to the original public meaning of the Fourteenth Amendment, civil rights could never in the future be conditioned on the basis of race, and segregation would always be unconstitutional. But if the Supreme Court follows the Warren Court's view in Harper, there are no constitutionally secured protections against segregation. Under originalism, segregation was unconstitutional in 1868, and Plessy v. Ferguson ${ }^{34}$ was

\footnotetext{
${ }^{31}$ See Scalia, supra note 27, at 37-38 (1997).

${ }^{32}$ Eliminating groups protected under the original meaning of the Fourteenth Amendment is precisely what the Supreme Court did in Carolene Products Footnote Four. There, the Court restricted the Amendment's protection to "discrete and insular minorities," 304 U.S. at 153, n.4, even though the Amendment originally protected everyone, even members of the majority; see also McDonald v. City of Chicago, 130 S. Ct. 3020, 3088-3120 (2010) (Stevens, J., dissenting) (arguing that the Second Amendment does not give individuals a substantive right to bear arms, even though the original meaning indicated otherwise).

33 383 U.S. 663, 669 (1966).

${ }^{34}$ Plessy v. Ferguson, 163 U.S. 537 (1896) (endorsing the concept of "separate but equal").
} 
wrong on the day it was decided. ${ }^{35}$ But under Harper, Plessy was correct in 1896, and segregation was permissible until the 1950 s when the Supreme Court said otherwise. ${ }^{36}$

We believe that the Fourteenth Amendment's broad ban on all class legislation and systems of caste prohibits the government from singling out any groups or individuals for unique burdens or privileges or immunities. Class legislation, which benefits or injures a limited class of individuals, can in essence be viewed as the opposite of legislation enacted to promote the general welfare, which benefits all citizens.

We find it hard to believe that the framers of the Fourteenth Amendment created a broad ban on class legislation, yet excluded religious individuals from protection against all forms of class legislation enacted on the basis of religion. The religion clauses of the Constitution and the Bill of Rights served as early, though limited, bans on some forms of class legislation directed against religion. Religion also enjoyed substantial protection in state constitutions in 1868 most of which had Free Exercise and Establishment Clause analogues. ${ }^{37}$

Constitutional protection against discrimination on the basis of religion has deep roots in American history going back to the founding generation. The founders were well aware of the evils of discrimination on the basis of religion which had been widespread both in Europe and in Colonial America, and they sought to guard against it. The three religion clauses in the Constitution of 1787 and in the Bill of Rights served as an initial, though limited, protection against certain specific forms of discrimination on the basis of religion. State constitutions also

\footnotetext{
${ }^{35}$ Calabresi \& Matthews, supra note 30 (setting out the originalist case against Plessy).

${ }^{36}$ Similarly, Harper allows future courts to reinterpret the Fourteenth Amendment's guarantee that no state shall "deprive any person of life, liberty, or property, without due process of law" as including fetuses, not just people. U.S. CONST. amend. XIV (emphasis added). See Abortion Case I, Federal Constitutional Court (Germany), 39 BVerfGE 1 (1975) (“'Everyone' within the meaning of [the Constitution] is 'every living human being,' or, put differently, every human individual possessing life; 'everyone' thus also includes the still unborn human being.") After all, why should it matter that in 1868 a "person" did not include a fetus?

${ }^{37}$ See Steven G. Calabresi \& Sarah E. Agudo, Individual Rights Under State Constitutions When the Fourteenth Amendment Was Ratified in 1868: What Rights are Deeply Rooted in American History and Tradition?, 87 Texas Law Review 1, 31-41 (2009).
} 
protected against certain forms of discrimination on the basis of religion in varying ways. But unfortunately discrimination on the basis of religion was quite prevalent during the Antebellum Period. Slaves in particular were subjected to harsh discrimination on the basis of religion, in addition to the general cruelty of slavery that they experienced. Abolition was partly sought to give slaves religious liberty. And the framers of the Fourteenth Amendment generally recognized that discrimination on the basis of religion was entirely unacceptable. When the Framers of the Fourteenth Amendment condemned the systematic mistreatment of African Americans during Reconstruction, those Framers frequently cited the Indian caste system as a comparable reprehensible social order. The Indian caste system was itself defined by and was in practice a class system based on religious distinctions. A typical Nineteenth Century dictionary definition of caste read, "In Hindostan, a tribe or class of the same profession, as the caste of Bramins; a distinct rank or order of society. ${ }^{38}$ Bramins were the priestly class at the top of India's religious caste system. So, in 1868, the literal dictionary definition of an undesirable system of "caste" was one that made reference to a religious caste system! The unavoidable conclusion is therefore that when the Framers banned systems of caste and of class legislation in general, they surely meant to ban class systems that were maintained by discrimination on the basis of religion.

Banning discrimination on the basis of religion is also consistent with global human rights law which bans discrimination on the basis of religion just as emphatically as it bans discrimination on the basis of race or gender. ${ }^{39}$ At least forty-five countries protect against discrimination on the basis of religion alongside protections against discrimination on the basis

\footnotetext{
${ }^{38}$ See, e.g., Chauncey A. GoOdrich, A Pronouncing ANd Defining Dictionary of The English Language 64, 75 (1856); JosePH E. WORCESTER, A UNIVERSAL AND CRITICAL DiCTIONARY OF THE ENGLISH LANGUAGE 107-08, 128 (1849) ("Caste, n. A distinct, hereditary order or class of people among the Hindoos, the members of which are of the same rank, profession, or occupation; an order or class"); see also Charles Sumner, lecture, The Question of Caste, 6-10 (Wright \& Porter Printers, 1869), available at http://ia600306.us.archive.org/5/items/questionofcaste00sumn/questionofcaste00sumn.pdf (discussing the Indian caste system at length).

${ }^{39}$ See discussion infra Part II.E.
} 
of race and gender. ${ }^{40}$ Some of those countries include such major world powers as Canada, Germany, France, India, and South Africa. The Universal Declaration of Human Rights and the European Convention on Human Rights and Freedoms also outlaws discrimination on the basis of religion. And in the United States, the Civil Rights Act of 1964 protected against discrimination on the basis of religion alongside its protections against discrimination on the basis of race and gender. Simply put, when people come together to ban discrimination and to guarantee equality, they include religion along with race and gender on the list of suspect classes.

We recognize that our reliance on the Fourteenth Amendment's anti-discrimination command in religion-related cases might appear novel, since courts generally rely on the Establishment Clause and the Free Exercise Clause of the First Amendment to decide religionrelated cases. We think the Supreme Court has probably felt obligated to take this path because the First Amendment's text speaks so directly about religion. In contrast, the text of the Fourteenth Amendment does not mention religion explicitly, although it is the Fourteenth Amendment and not the First that makes the Establishment Clause and the Free Exercise Clause applicable at all to the fifty states. Notwithstanding the constitutional text, there is no reason to think that all religion questions must be answered by the First Amendment, and that no religion questions can be answered by the Fourteenth Amendment anti-discrimination command standing alone. Indeed the Fourteenth Amendment's anti-discrimination command does not specifically use the words "race" or "gender" any more than it uses the word "religion." In fact, the Supreme Court as long ago as in 1938 in Carolene Products Footnote Four said that the Fourteenth Amendment protects religion from discrimination, just as much as it protects against race or national origin discrimination! ${ }^{41}$ And the Court made that observation even though it also

\footnotetext{
${ }^{40}$ See Appendix.

${ }^{41}$ Carolene Products Co., 304 U.S. at 155 n.4
} 
recognized that laws abridging First Amendment rights get strict scrutiny. ${ }^{42}$ The clear implication of Footnote Four is that religion gets Fourteenth Amendment protection in addition to and above and beyond any First Amendment protections that religion gets under the Establishment and Free Exercise Clauses. ${ }^{43}$ And that truism has been cemented by subsequent courts' almost ritualistic recitation that "[ $\mathrm{t}]$ he Equal Protection Clause prohibits selective enforcement based upon an unjustifiable standard such as race, religion, or other arbitrary classification."44 The Supreme Court has also never said that the Fourteenth Amendment's antidiscrimination command does not forbid discrimination on the basis of religion. The issue of whether the Fourteenth Amendment bars discrimination on the basis of religion has never truly been argued before the Court because the parties and the Court generally have focused exclusively on the First Amendment religion clauses to date. ${ }^{45}$ So, the Supreme Court could start using the Fourteenth Amendment to adjudicate discrimination on the basis of religion cases without contradicting its existing incorporated First Amendment case law. Even lower courts could start using the Fourteenth Amendment's anti-discrimination guarantee in religion cases without getting into trouble for stare decisis reasons because the Supreme Court has never said that only the incorporated First Amendment can be used in religion cases.

\footnotetext{
${ }^{42} I d$.

${ }^{43}$ See further discussion infra Part III.C.

${ }^{44}$ See United States v. Batchelder, 442 U.S. 114, 125 n.8 (1979) (citing Oyler v. Boles, 368 U.S. 448,456 (1962)) (emphasis added); see also United States v. Armstrong, 517 U.S. 456, 464, 116 S. Ct. 1480, 1486, 134 L. Ed. 2 d 687 (1996); Abcarian v. McDonald, 617 F.3d 931, 938 (7th Cir. 2010) (citing Engquist v. Oregon Dep't of Agriculture, 553 U.S. 591, 596 (2008); Plyler, 457 U.S. at 216-17) (stating that "[t] he Equal Protection Clause of the Fourteenth Amendment most typically reaches state action that treats a person poorly because of the person's race or other suspect classification, such as sex, national origin, religion, political affiliation, among others, or because the person has exercised a 'fundamental right,' or because the person is a member of a group that is the target of irrational government discrimination").

${ }^{45}$ Parties often mention the Equal Protection Clause as an afterthought, but they never treat equal protection as the principal argument. See, e.g., Brieffor Respondent, Locke v. Davey, 540 U.S. 712, at *44-45.
} 
In Part I of this paper, we discuss the original public meaning of the Fourteenth Amendment and its anti-discrimination command. In Part II, we explain how the Fourteenth Amendment applies to ban discrimination on the basis of religion. In Part III, we discuss how the original meaning of the Fourteenth Amendment compares to modern case law. In Part IV, we describe the connection between the Free Exercise and Establishment Clauses and the Fourteenth Amendment. In Part V, we explain why Blaine Amendments violate the Amendment and respond to a critical counterargument against my thesis. In Part VI, we apply the Fourteenth Amendment to the public school system. We think that public schools in their current form discriminate on the basis of religion. We then close with some concluding thoughts.

\section{The Original Meaning of the Fourteenth Amendment}

For nearly 150 years, the Supreme Court has mangled the words and basic structure of the Fourteenth Amendment. The Court's misreading of the Fourteenth Amendment began in 1873 in the Slaughter-House Cases, a case in which the Court, somewhat ironically, butchered the language of the Fourteenth Amendment. The Court's opinion in the Slaughter-House Cases rendered the Privileges or Immunities Clause - the most important clause in the Fourteenth Amendment - essentially meaningless. ${ }^{46}$ In subsequent years, the Court continued to ignore the Privileges or Immunities Clause, and eight justices adhered to that stance as recently as 2010, in McDonald v. City of Chicago, ${ }^{47}$ although Justice Clarence Thomas did call for reconsidering the Slaughter-House Cases. Since 1873, the Supreme Court has relied solely on the Equal Protection Clause of the Fourteenth Amendment as the textual source of the Fourteenth Amendment's antidiscrimination command. ${ }^{48}$ And in cases involving claims of individual fundamental rights, the

\footnotetext{
${ }^{46}$ Slaughter-House Cases, 83 U.S. 36 (1873).

${ }^{47} 130$ S. Ct. 3020 (2010).

${ }^{48}$ See e.g., Brown, 347 U.S. 483.
} 
Supreme Court has also ignored the Privileges or Immunities Clause and has instead analyzed those cases under its substantive due process doctrine. ${ }^{49}$

This approach has been largely unsettling to observers, since it leaves unanswered some fairly obvious questions. First, what happened to the Privileges or Immunities Clause? Second, how does a constitutional guarantee of due process of law translate into a substantive due process doctrine under which certain rights are absolutely protected? And third, how does a clause that guarantees the equal protection of existing laws also guarantee equality in the making of new laws? Ironically, the Supreme Court has reached mostly the right results in its case law while proceeding in every case under the wrong clauses of the Fourteenth Amendment. Because the current approach is so unsatisfying as an original matter, we begin with an originalist account of the whole text of the Fourteenth Amendment.

\section{A. The Text and Structure of the Fourteenth Amendment}

To understand the original meaning of Section One of the Fourteenth Amendment, one must begin with the original meaning of the Privileges or Immunities Clause. ${ }^{50}$ That Clause,

\footnotetext{
${ }^{49}$ See, e.g., Planned Parenthood of Southeastern Pennsylvania v. Casey, 505 U.S. 833 (1992).

${ }^{50}$ Modern scholarship on the original meaning of the Privileges or Immunities Clause began with John Harrison's article Reconstructing the Privileges or Immunities Clause, 101 Yale L. J. 1385 (1992), in which Harrison argued that the Clause was on an anti-discrimination guarantee and not a font of substantive due process individual rights. Phillip Hamburger reaches the same conclusion in Privileges or Immunities, 105 Nw. U. L. Rev. 61 (2011). See also David Currie, The Constitution in the Supreme Court: The First Hundred Years 342-51 (1985). Akhil Reed Amar and Randy Barnett read the Clause as protecting both against discrimination and as conferring un-enumerated individual rights. AKHIL REED AMAR, AMERICA'S UnWRITTEN CONSTITUTION: THE PRECEDENTS AND PRINCIPLES WE LIVE BY 157 (forthcoming 2012); RANDY BARNETT, RESTORING THE LOST CONSTITUTION: THE PRESUMPTION OF LIBERTY 62-65 (2004). Kurt Lash argues in a series of three law review articles which he is turning into a book that the Privileges or Immunities Clause protects both against discrimination and that it also protects enumerated but not un-enumerated individual rights. Kurt Lash, The Constitutional Referendum of 1866: Andrew Johnson and the Original Meaning of the Privileges or Immunities Clause, forthcoming law review article on file with the authors (2012); Kurt Lash, The Origins of the Privileges or Immunities Clause, Part I: "Privileges and Immunities" as an Antebellum Term of Art, 98 Geo. L. J. 1241 (2010); Kurt Lash, The Origins of the Privileges or Immunities Clause, Part II: John Bingham and the Second Draft of the Fourteenth Amendment, 99 Geo. L. J. 329 (2011). Robert Natelson argues in The Original Meaning of the Privileges and Immunities Clause, 43 Georgia L. Rev. 1117 (2009) for the John Harrison and Phillip Hamburger interpretation of the Privileges and Immunities Clause of Article IV, Section 2. Our own view of the Privileges or Immunities Clause of the Fourteenth Amendment is that it protects: 1) against laws that discriminate on the basis of class or caste and that are not just laws enacted for the good of the whole people; and that 2) it protects both enumerated individual rights and un-enumerated individual rights that are
} 
which the Framers of the Fourteenth Amendment thought was the most important Clause in the Amendment, says that "No State shall make or enforce any law which shall abridge the privileges or immunities of citizens of the United States." ${ }^{\text {51 }}$ The Privileges or Immunities Clause thus restricts the kind of laws a state can "make" or "enforce." The Privileges or Immunities Clause is the only clause in the Fourteenth Amendment which directly addresses the question of what laws a state legislature can constitutionally “make.” Noah Webster's 1828 Dictionary defines the verb "to make" as "to form," "to fashion," "to mold," or "to create." 52 The Privileges or Immunities Clause thus applies to the formation of laws. Laws can, of course, be made by the legislature as statutes, by the executive branch as regulations, or by the judiciary as judge-made common law. The Clause therefore forbids lawmakers from "making" any laws that "abridge," i.e. that "shorten" or "lessen" those rights which are the privileges or immunities of citizens of the United States. This reading of the Privileges or Immunities Clause has been advanced most vigorously in the modern era by Professor John Harrison ${ }^{53}$ and by Professor David Currie. ${ }^{54}$ In addition to banning the making of discriminatory laws, the Privileges or Immunities Clause also bans the enforcement of discriminatory state laws. Noah Webster's 1828 Dictionary defines the verb "to enforce" as "to strengthen," "to instigate," "to animate," "to give force to," or "to put in execution."

deeply rooted in history and tradition subject always to the caveat that the states can override such rights if they pass a just law that is enacted for the general good of the whole people. Our reading grows out of the foundational case of Corfield v. Coryell, 6 Fed. Cas. 546 no. 3230 C.C.E.D. Pa. (1823).

${ }^{51}$ U.S. CONST. amend XIV, § 1.

${ }^{52}$ NOAH WEBSTER's AMERICAN DICTIONARY (1828), available at http://www.1828-dictionary.com/ [hereinafter “WEBSTER'S 1828”].

${ }^{53}$ Harrison, supra note 20.

${ }^{54}$ Currie, supra note 50.

${ }^{55}$ Webster's 1828, supra note 52.

Enforce:

1. To give strength to; to strengthen; to invigorate. 
executive and judicial branches from executing any laws that "abridge" citizens' privileges or immunities. This no-enforcement language effectively prevents state executive branches from being able to claim that they had no choice but to execute a state legislature's unconstitutional laws. Taken together, the Privileges or Immunities Clause stops state governments from making or implementing any laws that unconstitutionally "abridge" citizens' privileges or immunities. ${ }^{56}$

The meaning attached to the Privileges or Immunities Clause was of course squarely before the Supreme Court in the Slaughter-House Cases. Since the first sentence of the Fourteenth Amendment makes everyone born or naturalized in the United States a citizen both of the United States and of the state wherein they reside, the privileges or immunities of citizens of the United States necessarily include both 1 ) their privileges or immunities of national citizenship and 2) their privileges or immunities of state citizenship. But the Slaughter-House majority denied this understanding. It seems quite obvious that the majority's reading ignored the Fourteenth Amendment's plain language. It was also general knowledge in 1866 to 1868 that a primary goal of the Fourteenth Amendment was to outlaw the Black Codes which abridged the state common law rights of contract, torts, and property of African Americans. To accomplish that objective, the Fourteenth Amendment simply has to be read as protecting the privileges or

2. To make or gain by force; to force; as, to enforce a passage.

3. To put in act by violence; to drive.

Stones enforced from the old Assyrian slings.

4. To instigate; to urge on; to animate.

5. To urge with energy; to give force to; to impress on the mind; as, to enforce remarks or arguments.

6. To compel; to constrain; to force.

7. To put in execution; to cause to take effect; as, to enforce the laws.

Id.

8. To press with a charge.

${ }^{56}$ See Harrison, supra note 20, at 1420-24, 1447-51. 
immunities of state citizenship as well as the privileges or immunities of national citizenship. But the Slaughter-House majority literally rendered the Fourteenth Amendment unintelligible. For that reason, the Supreme Court had to read back into the Equal Protection and Due Process Clauses all the content that it had wrongly drained from the Privileges or Immunities Clause.

But the original meaning of the Equal Protection Clause grants all persons the equal "protection" of the laws. In contrast to the Privileges or Immunities Clause, the Equal Protection Clause says nothing about equality in the making or implementing of equal laws. The noun in the Equal Protection Clause is "protection" and "equal" appears only as an adjective. The Clause is thus quite literally all about the "protection" of the laws. Therefore the text of the Equal Protection Clause declares that "no state shall ... deny to any person within its jurisdiction the equal protection of the laws." If the Clause had been meant to ban the making or formation of discriminatory laws, it should have read, "no state shall deny to any person equal laws" or just "no state shall deny to any person equality." The word "protection" - which again is the noun in the Equal Protection Clause -- would have been unnecessary if the Clause was about equality in the making of laws. Instead, the word "protection" adds meaning to the Equal Protection Clause because it makes it clear that the Clause is fundamentally about providing equality in the protection of those state constitutions and state statutes and state common law rules that were already made and that were in the statute books or that were in the recorded state case law. ${ }^{57}$

Noah Webster's 1828 Dictionary defines the word "protection" as meaning "defense; shelter from evil; preservation from loss, injury or annoyance." ${ }^{58}$ This definition shows that the Equal Protection Clause required the states to defend and shelter all people equally under their respective laws. No state could enforce its laws against murder to "protect" some people, such as

\footnotetext{
${ }^{57}$ This explanation contradicts the Supreme Court's declaration in Yick Wo v. Hopkins that "the equal protection of the laws" means "the protection of equal laws." See 118 U.S. 356, 369 (1886).

${ }^{58}$ WEBSTER's 1828, supra note 52.
} 
white southerners, but not others, such as Blacks or northerners residing in the South. Unlike the Privileges or Immunities Clause, the Equal Protection Clause is thus centrally concerned with the application or operation of laws that are already on the books or that are reported common law rights and that do not discriminate on their face. The guarantee of the "equal protection of the laws" means that a state must enforce its facially neutral laws and common law rules equally with regards to all persons. A state cannot, for instance, use its police power to protect whites but not blacks or enforce its contract law for the benefit of whites but not blacks. The Equal Protection Clause applies to both executive and judicial enforcement of otherwise valid laws.

As a historical matter, the Framers of the Fourteenth Amendment sought to ensure that southern states would protect blacks from violence and from being denied the equal "protection" of those facially neutral laws that were already on the books. ${ }^{59}$ Philosophically, the Equal Protection Clause recognized the Lockean principle that individuals sacrifice the individual freedoms with which they are born and retain in the state of nature in exchange for the equal protection of the laws. ${ }^{60}$

It is well-established that the American people understood that by enacting the Fourteenth Amendment they were writing into federal constitutional law the Civil Rights Act of 1866 which had abolished the Black Codes. The Black Codes were a series of racially discriminatory laws

\footnotetext{
${ }^{59}$ See Harrison, supra note 20, at 1437 (discussing how the Equal Protection Clause enabled Congress to pass the Ku Klux Act of 1871).

${ }^{60}$ See BlaCKSTONE's COMMENTARIES, Editor's App. 47-48 (S. Tucker ed. 1803) [hereinafter "BlaCKSTONE'S COMMENTARIES"] ("that the whole should protect all of it's [sic] parts, and that every part should pay obedience to the will of the whole; or, in other words, that the community should guard the rights of each individual member, and that (in return for this protection) each individual should submit to the laws of the community; without which submission of all it was impossible that protection could be certainly extended to any.")
} 
adopted by southern states in 1865 and 1866 to reduce freedmen to second class social status. ${ }^{61}$

The Civil Rights Act of 1866 read as follows:

[A]ll persons born in the United States and not subject to any foreign power, excluding Indians not taxed, are hereby declared to be citizens of the United States; and such citizens, of every race and color, without regard to any previous condition of slavery or involuntary servitude, except as a punishment for crime whereof the party shall have been duly convicted, shall have the same right, in every State and Territory in the United States, to make and enforce contracts, to sue, be parties, and give evidence, to inherit, purchase, lease, sell, hold, and convey real and personal property, and to full and equal benefit of all laws and proceedings for the security of person and property, as is enjoyed by white citizens, and shall be subject to like punishment, pains, and penalties, and to none other, any law, statute, ordinance, regulation, or custom, to the contrary notwithstanding. ${ }^{62}$

The Civil Rights Act of 1866 thus guaranteed two forms of legal equality. First, it barred states from "making" or "enforcing" any law that failed to give citizens "of every race and color" the "same" common law rights as were "enjoyed by white citizens." And second, it prevented the states from unequally enforcing otherwise valid laws that were facially non-discriminatory so as to protect some classes of citizens and not others. This provision addressed such obvious problems as how blacks could possibly buy and own property if they could not rely on the police for "protection" when violent whites came to throw them off their land.

The Fourteenth Amendment was proposed and ratified to, at a minimum, constitutionalize the Civil Rights Act of 1866. President Andrew Johnson had vetoed the Act

\footnotetext{
${ }^{61}$ See Harrison, supra note 20, at 1402-1405. Senator Lyman Trumbull maintained that abolition under the Thirteenth Amendment permitted Congress to pass laws protecting blacks from badges of slavery, such as the Black Codes, and to protect blacks' legal rights. He accordingly said, Since the abolition of slavery, the Legislatures which have assembled in the insurrectionary States have passed laws relating to the freedmen, and in nearly all the States they have discriminated against them. They deny them certain rights, subject them to severe penalties, and still impose upon them the very restrictions which were imposed upon them in consequence of the existence of slavery, and before it was abolished. The purpose of the bill under consideration is to destroy all these discriminations, and to carry into effect the constitutional amendment. CONG. GLOBE, 39TH CONG., 1ST SESS. 474 (1866).

${ }^{62}$ Act of Apr. 9, 1866, ch. 31, § 1, 14 Stat. 27.
} 
because he felt that it exceeded Congress's power to enforce the Thirteenth Amendment's ban on slavery. Congress responded by overriding his veto and ultimately ratifying the Fourteenth Amendment. The substantive rights or privileges or immunities protected by the Act are all obviously state common law rights, such as the right to make contracts, own property, inherit, and testify. It was these common law rights of state citizenship that the Privileges or Immunities Clause and the Equal Protection Clause were meant to safeguard. All originalist scholars, including Raoul Berger, agree that at a minimum the Fourteenth Amendment constitutionalized the list of rights in the Civil Rights Act of $1866 .{ }^{63}$ The Slaughter-House Cases eviscerated that purpose and was therefore clearly wrong.

The two primary forms of legal equality guaranteed in the Civil Rights Act were thus infused into the Fourteenth Amendment. As Professor Harrison has argued, the guarantee of equal enforcement of facially non-discriminatory laws was encapsulated in the Equal Protection Clause, while the guarantee of equality in the "making" of laws was enshrined in the Privileges or Immunities Clause.$^{64}$ Modern readers may wonder how the Privilege or Immunities Clause might be understood as ban on discriminatory law-making.

The answer is that the Clause forbids the making of laws that give one class of citizens an "abridged" or shortened or lessened set of rights as compared with another class of citizens. The verb "abridge" is used in precisely this anti-discriminatory way in the Fifteenth Amendment

\footnotetext{
${ }^{63}$ See, e.g., RAOUl BERGER, SELECTEd Writings ON THE CONSTITUtion 185 (1987) ( "[T] evidence, confirmed in these pages, is that the framers [of the Fourteenth Amendment] repeatedly stated that the amendment and the Civil Rights Act of 1866 were 'identical'...."); see also ANDREW KULL, THE COLOR-BLIND CONSTITUTION 75 (1992) ("It was the demonstrable consensus of the Thirty-ninth Congress that section 1 of the Fourteenth Amendment 'constitutionalized' the Civil Rights Act of 1866.”); MichAEL J. PERRY, We THE PEOPLE: THE FourteENTH AMENDMENT AND THE SUPREME COURT 72 (1999) ("Recall that, whatever else it did, the second sentence of section one constitutionalized the 1866 Civil Rights Act."); 2 RALPH A. ROSSUM \& G. ALAN TARR, American Constitutional LaW: THe Bill of Rights AND SubSEQUent AMENDMENTS 53 (8th ed. 2010) ("The Fourteenth Amendment was obviously designed to constitutionalize the Civil Rights Act of 1866.”).

${ }^{64}$ See Harrison, supra note 20, at 1414-33.
} 
which says that "The right of citizens of the United States to vote shall not be denied or abridged by the United States or by any State on account of race, color, or previous condition of servitude." Of course, the verb "abridge" can also apply to individual abridgements of rights as when an individual's right to the freedom of speech or of the press is "abridged" in violation of the First Amendment. Rights can be shortened or lessened by one person at a time or by one class of people at a time. The original plain public meaning of the verb "abridge" in the Privileges or Immunities Clause thus obviously forbids both discriminatory "abridgements" and "abridgements" that occur as denials of individual rights that are deeply rooted in history and tradition. Because the Slaughter-House Cases strangled the Privileges or Immunities Clause in its crib, discriminatory abridgements of rights are today analyzed under the Equal Protection Clause, while abridgements of individual rights are analyzed using substantive due process. In the Nineteenth Century, the words "privileges" and "immunities" were synonymous with the phrase "positive law rights," and these terms were often used side by side. ${ }^{65}$ The word "privilege" in particular comes from the Latin words "privi" which means private and "legis" which means law. ${ }^{66} \mathrm{~A}$ "privilege" is therefore not a right enjoyed under natural law but is instead only a right that is enjoyed under positive law. Noah Webster's 1865 Dictionary defined the word "privilege" as being "a right or immunity not enjoyed by others or by all," and Webster's cited the words "immunity," "franchise," "right," and "liberty" as being synonyms. ${ }^{67}$ Webster's defined the word "immunity" as meaning "[f]reedom from an obligation" or a "particular

\footnotetext{
${ }^{65}$ See generally McDonald, Ill., 130 S. Ct. at 3063-3078 (Thomas, J., Concurring) (discussing the meaning of "privileges" and "immunities").

${ }^{66}$ ROBERT K. BARNHART (ed.), THE BARNHART DiCTIONARY OF ETYMOLOGY 841 (1988).

${ }^{67}$ NoAh Webster, AN AMERICAN Dictionary Of THE English LANGUAGE 1039 (C. Goodrich \& N. Porter rev. 1865) [hereinafter "WeBSTER's 1865"]; See also 2 C. RiCHARDSON, A NeW DiCTIONARY OF THE ENGLISH LANGUAGE 1512 (1839) (defining "privilege" as "an appropriate or peculiar law or rule or right; a peculiar immunity, liberty, or franchise").
} 
privilege." ${ }^{68}$ The word "immunity" has the same positive law connotation as does the word "privilege". 69 And Webster's defined the word "right" as meaning a "[p]rivilege or immunity granted by authority.",70 Similarly, William Blackstone described the "rights and liberties" of Englishmen as being "private immunities" and "civil privileges.", v. Brown said that "'privileges and immunities' relate to the rights of persons, place or property; a privilege is a peculiar right, a private law, conceded to particular persons or places.",72

The substance of these rights or "privileges or immunities" encompassed all of the common law rights of contract, property, torts, and inheritance guaranteed in the Civil Rights Act of 1866. The Act thus guaranteed that all citizens of every race and color should enjoy the same state law rights as to property, contract, family law, and tort. As all commentators on the original meaning of the Fourteenth Amendment have argued, the drafters and ratifiers of the Amendment understood the words "privileges or immunities" to mean much the same thing as was meant by those exact same words in the Privileges and Immunities Clause of Article IV. This Clause was understood in 1868 as having the expansive meaning that Supreme Court Justice Bushrod Washington had given the Article IV Privileges and Immunities Clause while riding circuit in $1823 .^{73}$ In Corfield v. Coryell, Justice Washington defined the Privileges and Immunities Clause of Article IV in quite expansive terms. He said that:

The inquiry is, what are the privileges and immunities of citizens in the several states? We feel no hesitation in confining these expressions to those privileges and immunities which are, in their nature, fundamental; which belong, of right, to the citizens of all free governments; and which have, at all times, been enjoyed by the citizens of the several states which compose this Union, from the time of their becoming free, independent, and sovereign. What these fundamental

\footnotetext{
${ }^{68}$ WEBSTER's 1865, supra note 67, 166; see also Richardson, supra note 62, at 1056 (defining “immunity" as "[f]reedom or exemption, (from duties, liberty, privilege").

${ }^{69}$ BARNHART, supra note 66, at 510.

${ }^{70}$ WEBSTER's 1865 , supra note 67 , at 1140.

${ }^{71}$ BLACKSTONE's COMMENTARIES, supra note 60, at 129.

${ }^{72}$ Magill v. Brown, 16 F. Cas. 408, 428 (No. 8,952) (CC ED Pa. 1833).

${ }^{73}$ See Harrison, supra note 20, at 1410.
} 
principles are, it would perhaps be more tedious than difficult to enumerate. They may, however, be all comprehended under the following general heads: Protection by the government; the enjoyment of life and liberty, with the right to acquire and possess property of every kind, and to pursue and obtain happiness and safety; subject nevertheless to such restraints as the government may justly prescribe for the general good of the whole. The right of a citizen of one state to pass through, or to reside in any other state, for purposes of trade, agriculture, professional pursuits, or otherwise; to claim the benefit of the writ of habeas corpus; to institute and maintain actions of any kind in the courts of the state; to take, hold and dispose of property, either real or personal; and an exemption from higher taxes or impositions than are paid by the other citizens of the state; may be mentioned as some of the particular privileges and immunities of citizens, which are clearly embraced by the general description of privileges deemed to be fundamental: to which may be added, the elective franchise, as regulated and established by the laws or constitution of the state in which it is to be exercised. These, and many others which might be mentioned, are, strictly speaking, privileges and immunities ... ${ }^{74}$

This sprawling list of constitutionally protected privileges and immunities encompasses a huge number of federal, state, and common law rights so long as they are deeply rooted in American history and tradition as the first bold faced passage above indicates. New-fangled rights, like the so-called right to privacy, are simply not privileges or immunities because the right to privacy is not deeply rooted in American history and tradition.

Justice Washington also sets up a second rights limiting principle in the second boldfaced passage in the excerpt quoted above. Justice Washington says that all privileges or immunities are "subject nevertheless to such restraints as the government may justly prescribe for the general good of the whole." 75 And this is where the Privileges or Immunities Clause's ban on class legislation comes into play. The government can only pass a law that diminishes traditional common law privileges or immunities if the law serves the "general good of the whole [people]" but not if it is mere class legislation. ${ }^{76}$ Professor Harrison thus argues that the Privileges or Immunities Clause of the Fourteenth Amendment protects Corfield's expansive list

${ }_{75}^{74}$ F. Cas. 546, 551-52 (C.C.E.D. Pa. 1823) (No. 3230).

$75 \frac{6 F .}{I d}$ at 552.

${ }^{76}$ See Id. 
of rights but subject to the caveat that states can legislate to abridge rights when doing so protects the general good of the whole people. ${ }^{77}$ Professor Harrison therefore reads the word "abridge" in the Privileges or Immunities Clause as forbidding only class-based legislation. ${ }^{78}$

The Clause allows states to make laws that further the good of the whole people, but states may not discriminate against classes of people either on the basis of race or some other criterion that does not benefit the public generally. In other words, Professor Harrison reads the Privileges or Immunities Clause as if it said, "No state shall make or enforce any law which abridges the rights of citizens of the United States in a way that improperly discriminates or that does not promote the general good of the whole people." Professor Harrison goes to great lengths to show that the framers viewed the Privileges or Immunities Clause of the Fourteenth Amendment as being solely an anti-discrimination provision. ${ }^{79}$ Harrison thus claims erroneously that incorporation of the Bill of Rights was a mistake at least as a matter of law. He overlooks that a state can quite literally abridge rights one citizen at a time as well as by one class of citizens at a time.

The Privileges or Immunities Clause describes the general rights of citizens as being privileges or immunities, instead of rights, because the Framers of the Fourteenth meant by that Clause to protect only the rights of citizens and not the rights of non-citizens or of all people. ${ }^{80}$ The Due Process and Equal Protection Clauses of the Fourteenth Amendment, in contrast, apply to all persons and not merely to citizens. The rights detailed in Corfield were thus special rights possessed only by citizens and not necessarily rights that were available to all inhabitants of the

\footnotetext{
${ }^{77}$ See Harrison, supra note 20, at 1452.

${ }^{78}$ See Id. at 1422.

${ }^{79}$ See Id. at 1410-1433. For instance, Representative Samuel Shellabarger said that the Privileges or Immunities Clause "[r] equires that the laws on their face shall not 'abridge' the privileges or immunities of citizens. It secures equality toward all citizens on the face of the law. It provides that those rights shall not be 'abridged;' in other words, that one man shall not have more rights upon the face of the laws than another man. By that provision equality of legislation, so far as it affects the rights of citizenship, is secured." CONG. GLOBE, 42D CONG., 1ST SESS. 71 app. (1871).

${ }^{80}$ See Harrison, supra note 20, at 1442-1447 (discussing differences in rights available to citizens and aliens).
} 
United States. The framers of the Fourteenth Amendment left open the possibility that future legislatures might not want to give aliens all of the rights of citizens. Republican Representative Horatio Burchard of Illinois said, "The privileges and immunities of a citizen of the United States are those particular advantages or exemptions secured or granted to them, but not extended to all persons, and from which aliens may lawfully be debarred."

The Privileges or Immunities Clause does not bar the states from altering the rights of its citizens that are deeply rooted in history and tradition so long as the alteration is made in a just, general law enacted for the good of the whole people. What is clearly banned, however, is legislation that favors one class or caste of people over another. Put another way, the Privileges or Immunities Clause bars discrimination by forbidding the states from giving greater privileges or immunities to one class of citizens as compared to another class of citizens.

What was the original public meaning of class legislation or of improper discrimination in 1868? Raoul Berger and former Chief Justice William Rehnquist claimed in the 1970's that the Fourteenth Amendment only banned discrimination based on race and national origin and nothing more. ${ }^{82}$ Justice Felix Frankfurter, and a majority of the New Deal Supreme Court held specifically that sex discrimination was not a suspect classification under the Fourteenth Amendment in Goesaert v. Cleary a decision that was in tension with language in Adkins v. Children's Hospital ${ }^{83}$ and that was correctly overruled in Craig v. Boren ${ }^{84}$ Supporters of this New Deal rational basis test argument claim that the Framers of the Fourteenth Amendment simply sought to end discrimination against the freed slaves and nothing more. The Slaughter-

\footnotetext{
${ }^{81}$ CONG. GLOBE, 42D CONG., 1St SESS. 313-14 app. (1871).

${ }^{82}$ See RAOUL BERGER, GOVERNMENT BY JUDICIARY: THE TRANSFORMATION OF THE FOURTEENTH AMENDMENT 191 (1977); see also Trimble, 430 U.S. at 777 (Rehnquist, J., dissenting) (arguing that "[e]xcept in the area of the law in which the Framers obviously meant [Section One] to apply-- classifications based on race or on national origin, the first cousin of race," the Court's decisions may be described as "an endless tinkering with legislative judgments, a series of conclusions unsupported by any central guiding principle").

${ }^{83} 261$ U.S. 525 (1923).

${ }^{84} 335$ U.S. 464 (1948) overruled by 429 U.S. 190 (1976).
} 
House majority seemed to take a similar view saying: "We doubt very much whether any action of a State not directed by way of discrimination against the negroes as a class, or on account of their race, will ever be held to come within the purview of this provision." 85

But this narrow conception of the Fourteenth Amendment as barring only race discrimination and not other forms of discrimination is at war with both the text and the original public meaning of the Amendment. Section One of the Fourteenth Amendment is written broadly, guaranteeing "any person" equal protection of the laws and barring the states from making any law that abridges the privileges or immunities of "citizens of the United States." 86 The text of Section One gives absolutely no indication that the Amendment applies to only race discrimination and not to other forms of discrimination more generally. Section One of the Fourteenth Amendment thus stands in stark contrast with Section Two of the Fourteenth Amendment, which protects only the right of "males" to vote. ${ }^{87}$ The text of Section One of the Fourteenth Amendment also differs from the text of Section One of the Fifteenth Amendment which only forbids abridging the right to vote "on account of race, color, or previous condition of servitude. ${ }^{, 88}$ And Section One of the Fourteenth Amendment contrasts with the No Religious Test Clause which bars Congress from conditioning the right to hold public office on the basis of religion but leaves open the possibility that eligibility to hold public office could be restricted on some other basis. ${ }^{89}$ Simply put, when the Framers of both the original Constitution and of the Reconstruction Amendments wanted a constitutional provision to apply to only race, color, or previous condition of servitude, they made their intent explicit in the text. Thus, when the

\footnotetext{
${ }^{85}$ Slaughter-House Cases, 83 U.S. at 81.

${ }^{86}$ U.S. CONST. amend. XIV.

${ }^{87}$ See U.S. CONST. amend. XIV $\S 2$ (ensuring that states shall not abridge the right to vote of "male inhabitants").

${ }^{88}$ U.S. CONST. amend. XV, $\S 1$ ("The right of citizens of the United States to vote shall not be denied or abridged by the United States or by any State on account of race, color, or previous condition of servitude.)

${ }^{89}$ U.S. CONST. art. VI, § 3 ("no religious Test shall ever be required as a Qualification to any Office or public Trust under the United States").
} 
Framers of the Nineteenth Amendment wanted to give women the right to vote, they wrote an Amendment that explicitly said "The right of citizens of the United States to vote shall not be denied or abridged by the United States or by any State on account of sex." ${ }^{, 90}$ If the framers of the Fourteenth Amendment wanted to merely end class-based legislation that was racially discriminatory, they would have said so explicitly. The fact that they chose broader language shows that they meant to ban all forms of class legislation and not merely the Black Codes.

The language of the Fourteenth Amendment tracks other constitutional provisions which have a broad application despite the narrow historical contexts in which those provisions were ratified. For example, the Thirteenth Amendment's sweeping, unqualified language bans the enslavement of any individual, ${ }^{91}$ even though the Thirteenth Amendment was, as a historical matter, a direct response to the slavery of African Americans. Surely no one would claim that some new form of non-race based slavery is permissible under the Thirteenth Amendment. Obviously such a new system of slavery would be blatantly unconstitutional.

Similarly, no one would claim that the Fourteenth Amendment's Due Process Clause, which bars the states from depriving "any person of life, liberty, or property, without due process of law," 92 only guarantees racial groups due process rights because in 1868 the framers were primarily concerned with protecting the due process rights of African Americans. The language "any person" should have the same meaning in the Equal Protection Clause as it does in the Due Process Clause. Because both the Equal Protection and Due Process Clauses apply to "any person," it is quite incoherent to claim that that the Equal Protection Clause pertains only to race,

\footnotetext{
${ }^{90}$ U.S. CONST. amend XIX (emphasis added).

${ }^{91}$ U.S. CONST. amend. XIII, $\S 1$ ("Neither slavery nor involuntary servitude, except as a punishment for crime whereof the party shall have been duly convicted, shall exist within the United States, or any place subject to their jurisdiction.); See also U.S. CONST. amend. V ("nor shall any person be subject for the same offense to be twice put in jeopardy of life or limb") (emphasis added).

92 See U.S. CONST. amend. XIV.
} 
national origin, or some other subset of society. To make this claim, one would have to explain how the term "any person" can have two different meanings within the same sentence. It is instead much more plausible to conclude that the unqualified language of the Fourteenth Amendment applies broadly to protect all classes of citizens from abridgements of their privileges or immunities and all classes of persons from denials of due process or of the equal protection of the laws. As we will now explain, Section One of the Fourteenth Amendment did in fact protect all citizens from class legislation and from the legal imposition of systems of caste.

Before making this argument, we should note that some scholars like Professor Melissa Saunders, with whom we agree with regards to the Fourteenth Amendment's ban on class legislation, disagree with Professor Harrison's and Professor Currie's view of the Privileges or Immunities and Equal Protection Clauses that we have just articulated. Saunders is bothered by a handful of remarks made by a few legislators during Reconstruction indicating that they thought that the Equal Protection Clause in fact guaranteed equality in law making as well as in law execution. ${ }^{93}$ For instance, Representative James Garfield said that the Equal Protection Clause prohibited the states from "mak[ing] or enforc[ing] laws which are not on their face and in their provisions of equal application to all the citizens of the State . . like the air of heaven, covering all and resting upon all with equal weight."94 The problem with Professor Saunders' argument is that the isolated snippets of legislative history upon which she relies are not plausibly related to the original objective public meaning of the text of the Fourteenth Amendment, as we have already discussed. Professor Saunder's snippets reflect nothing more than the subjective understanding of a few lawmakers who misread the Amendment's text. Legislative history may sometimes be helpful in explaining the objective public meaning of legal texts, but legislative

\footnotetext{
${ }^{93}$ See Saunders, supra note 19, at 288-293.

${ }^{94}$ Cong. Globe, 42D Cong., 1St SeSS. H. APP. 153 (1871).
} 
history is manifestly not helpful when it openly defies the text's objective dictionary meaning. It simply does not matter that Congressman Garfield did not understand that the noun in the Equal Protection Clause is "protection" and not "equal," while it is the Privileges or Immunities Clause that is about the "making" of laws. Rebutting Professor Harrison's textual analysis requires much more than just a few snippets of legislative history in conflict with the constitutional text.

Nevertheless, it is not necessary that one agree with Professor Harrison, as we do, to accept the notion that Section One of the Fourteenth Amendment as a whole banned all class legislation. Whether the Fourteenth Amendment guarantees equality via two clauses or one is not critical. For that reason, both Professor Harrison and Professor Saunders recognize that the Amendment bans all class legislation even if they disagree as to how it does. ${ }^{95}$

\section{B. The Fourteenth Amendment's Ban on Caste and Class Legislation}

The terms "caste" and "class" had related and at times overlapping meanings and both referred to social hierarchies which privileged some individuals and groups while disadvantaging and degrading others. Yet Nineteenth Century contemporaries generally assigned distinct meanings to each term. We discuss both terms below.

\section{Definition of "caste" and "class legislation"}

The word "class" was used in the context of "class legislation" which was any form of legislation that singled out groups or individuals for special privileges or burdens apart from those born by the rest of the members of society. During the Antebellum Period, class laws were often called "special" or "partial" laws ${ }^{96}$ because they did not apply to the people as a whole and because they often granted monopolies or other special privileges to a favored group or imposed

\footnotetext{
${ }^{95}$ See Harrison, supra note 20; Saunders, supra note 19.

${ }^{96}$ Professor Saunders reports, "In the mid-nineteenth century, lawyers and judges began to use the term "class legislation" as a synonym for partial or special laws. See, e.g., Monroe v. Collins, 17 Ohio St. 666, 673 (1867) (argument of counsel); Lehman v. McBride, 15 Ohio St. 573, 606-07 (1863) (using class legislation to describe legislation in which "operation is limited to ... certain classes of persons")." Saunders, supra note 19, at 252 n. 29.
} 
unique burdens on a particular disfavored group. ${ }^{97}$ Generally, special laws created unique privileges for a particular class, and partial laws created unique disadvantages for a particular class, although the value of distinguishing between special and partial laws is debatable. ${ }^{98}$

The word "class" had a generic definition in the Nineteenth Century. It was generally defined as a "rank; order of persons or things; scientific division or arrangement." 99 The designation therefore of a particular group of people as a protected class did not depend on whether that group was a minority, nor did it depend on whether that group had been previously subjected to persecution, or nor did the class need to be distinguished by hereditary or immutable features. As Thomas Cooley put it in his treatise, "every one has a right to demand that he be governed by general rules." ${ }^{100}$ Cooley repeated John Locke's famous tenet that legislators "“are to govern by promulgated, established laws, not to be varied in particular cases, but to have one rule for rich and poor, for the favorite at court and the countryman at plough.",101

\footnotetext{
${ }^{97}$ Saunders cites several examples. See, e.g., Reed, 2 Greene at 28 (defining a special law as one "confined to a particular class of individuals"); Lewis, 3 Me. at 336 (defining a special law as one "granting a privilege and indulgence to one man, by way of exemption from the operation and effect of [a] general law, leaving all other persons under its operation"); Jones' Heirs, 18 Tenn. (10 Yer.) at 78 (defining a partial or special law as one that is "restricted in its operation" to certain persons); Wally's Heirs, 10 Tenn. (2 Yer.) at 556 (defining a partial law as one that is "limited in its operation ... to a very few individuals"); Vanzant v. Waddel, 10 Tenn. (2 Yer.) 260, 269 (1829) (Peck, J.) (describing a partial law as one "which is partial in its operation, intended to affect particular individuals alone, or to deprive them of the benefit of the general laws"); Id. (Catron, J., concurring) (describing a partial law as one that "tend[s] directly or indirectly to deprive a corporation or an individual of rights ... to the equal benefits of the general and public laws of the land"). See Saunders, supra note 19, at 252 n.29.

${ }^{98}$ See Correspondence between the House of Representatives of the State of Maine and the Supreme Judicial Court of Maine, 58 Me. 590, 593 (1871) (opinion of Appleton, C.J., Walton, \& Danforth, JJ.) (observing that "a discrimination in favor of one ... is a discrimination adverse to all other [s]"); Note, Developments in the Law Equal Protection, 82 Harv. L. Rev. 1065, 1086 n.47 (1969) ("[W]hen a benefit is extended to one group but refused to another, the excluded group may be seen as suffering a relative burden"); Saunders, supra note 19, at 269 n.102.

${ }^{99}$ Goodrich, supra note 38, at 75; Worcester, supra note 38, at 128 ("A rank or order of persons or things; a division; a set of pupils or students of the same form, rank, or degree; a general or primary division"); WEBSTER'S 1828, supra note 52 ("An order or rank of persons; a number of persons in society, supposed to have some resemblance or equality, in rank, education, property, talents, and the like; as in the phrase, all classes of men in society").

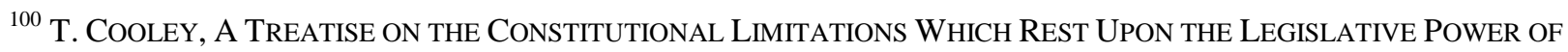
THE STATES OF THE AMERICAN UNION 459 (3d ed. 1874) [hereinafter "CONSTITUTIONAL LIMITATIONS"]. ${ }^{101} I d$.
} 
In contrast, the word "caste" generally referred to rigid and immutable social divisions based on hereditary traits with which a person was born. A definition of the word "Caste" did not appear in American dictionaries until the mid-Nineteenth Century. ${ }^{102}$ When dictionaries began defining the word and when people began using it in common parlance, the Indian caste system was almost always used as the word's defining benchmark. This makes sense because the Portuguese first used the word "caste" to describe the Indian system of social hierarchy. ${ }^{103}$ A typical definition of caste was "In Hindostan, a tribe or class of the same profession, as the caste of Bramins; a distinct rank or order of society."104 Senator Charles Sumner explained that a "[caste] system had two distinct elements: first, separation, with rank and privilege, or, their opposite, with degradation and disability[;] secondly, descent from father to son[;] so that it was perpetual separation from generation to generation." 105 Sumner observed that in the Indian caste system one person "claimed hereditary rank and privilege" and another is "doomed to hereditary degradation and disability." ${ }^{106}$ In India, people were born into a particular caste and were unable to change their caste. In describing the caste system of Europe, Sumner said,

people were distributed into classes and the son succeeded to the condition of his father whether of privilege or disability the son of a noble being a noble with great privileges the son of a mechanic being a mechanic with great disabilities and this inherited condition was applicable even to the special labor of the father nor

\footnotetext{
${ }^{102}$ Neither Samuel Johnson's 1786 Dictionary nor Noah Webster's 1828 Dictionary contained a definition for the word "caste." Charles Sumner said that "the word is too modern, however, for our classic English literature" and noted how dictionaries excluded the word. Sumner, supra note 38, at 7.

${ }^{103}$ NOAH WEBSTER, AN AMERICAN DictionARY OF THE ENGLISH LANGUAGE 152 (1857) [hereinafter “WeBSTER'S 1857"] ("In Hindostan, a name (from casta, race) first given by the Portuguese to the several classes into which society is divided, having fixed occupations, which have come down from the earliest ages. There are four great and many smaller castes. 2. A distinct order in society.")

${ }^{104}$ See, e.g., Goodrich, supra note 38, at 64, 75; Worcester, at supra note 38, at 107-08, 128 ("Caste, n. A distinct, hereditary order or class of people among the Hindoos, the members of which are of the same rank, profession, or occupation; an order or class"); Sumner, supra note 38, at 6-10 (discussing the Indian caste system at length).

${ }^{105}$ Sumner, supra note 38 , at 7 .

${ }^{106} I d$. at 10 (referencing the Indian caste system).
} 
was there any business beyond its tyrannical control. According to Macaulay the tinkers formed an hereditary caste. ${ }^{107}$

Accordingly, Nineteenth century dictionaries defining "caste" referred to it as a "hereditary order,"108 "fixed occupations," and a "distinct order in society"109 - all of which express the principles of immutability and heredity which were the key features of caste.

Notably, the Nineteenth Century definition of caste was not limited to only racial or even physical features. Instead a "caste" could mean "a tribe or class of the same profession,"110 people with "fixed occupations," "111 people with "the same rank, profession, or occupation," or simply "an order or class." 112 These definitions clearly encompassed classifications based on status or conduct which had nothing to do with racial or physical features. And the Nineteenth Century definition of caste also included classifications based on religion. ${ }^{113}$

A caste was therefore considered one kind of a class, and laws supporting a caste system were simply one form of class legislation. Accordingly, one of the definitions of "caste" was that it constituted a "class." ${ }^{114}$ As Senator H. Wilson put it in arguing for black suffrage, class legislation was the means by which a system of caste could be structured and maintained. ${ }^{115}$

One important qualification was that class legislation was permissible during the Antebellum period if it served an important public purpose, benefiting society as a whole. ${ }^{116}$ As

\footnotetext{
${ }^{107} I d$. at 7. Sumner also referenced caste systems in Persia, Egypt, Peru, Assyria, and Attica.

${ }^{108}$ Worcester, supra note 38, at 107-08, 128.

${ }^{109}$ WEBSTER's 1857, supra note 103, at 152 (emphasis added).

${ }^{110}$ Goodrich, supra note 38, at 64, 75 .

${ }^{111}$ WEBSTER's 1857, supra note 103, at 152.

${ }^{112}$ Worcester, supra note 38, at 107-08, 128.

${ }^{113}$ See infra Part II.A.

${ }^{114}$ Worcester, supra note 38, at 107-08, 128.

115 See 40TH CONGRESS 3RD SESSION CONG. GlOBE 153 (1869) (appendix) (statement by Senator H. Wilson ("to maintain by class legislation the abhorrent doctrine of caste").

${ }^{116}$ Justice Bushrod Washington said in Corfield that citizens' privileges and immunities were "subject nevertheless to such restraints as the government may justly prescribe for the general good of the whole." 6 F. Cas. at 552.

Melissa Saunder cites several example cases for this public purpose principle. See Saunders, supra note 19, at 261

n.68 (citing Blackington, 41 Mass. (24 Pick.) at 358-59 (rejecting a partial law challenge to a law forbidding the sale of intoxicating liquors without a license on the ground that the law's "real object" was "to promote the public good,"
} 
Justice Field explained, "[s]pecial burdens are often necessary for general benefits," such as "supplying water, preventing fires, lighting district, cleaning streets, opening parks, and many other objects." ${ }^{\text {117 }}$ Justice Field added that the Fourteenth Amendment prohibits "[c]lass legislation, discriminating against some and favoring others," but not "legislation which, in carrying out a public purpose, is limited in its application" to certain individuals or groups. ${ }^{118}$ Thus, the Fourteenth Amendment permits laws that discriminate if they "are designed, not to impose unequal or unnecessary restrictions upon any one, but to promote, with as little individual inconvenience as possible, the general good." ${ }^{, 19}$ Class legislation therefore differs from laws regulating conduct which are generally applicable to all persons. For instance, criminal laws prohibiting stealing or civil laws delineating a standard of care in tort actions regulate the conduct of all persons. Thus the legislature could safely pass a law prohibiting embezzlement, but it could not pass such a law if it only applied only to the employees of a specific bank. ${ }^{120} \mathrm{We}$ will elaborate on class legislation doctrine more in Part III.

\section{Historical evidence of opposition to class legislation}

rather than to confer a special advantage on the licenseholders); Hewitt, 33 Mass. (16 Pick.) at 356 (rejecting a partial law challenge to a law conferring a special benefit on licensed medical practitioners on the ground that the law's "leading and sole purpose" was "to guard the public," rather than "to promote the[ ] private interests" of the licenseholders); Blackington, 41 Mass. (24 Pick.) at 358-59 (holding that laws which have the "effect" of conferring special benefits upon certain persons are not invalid, so long as that effect is "collateral and incidental" to a "purpose ... to promote the public good," rather than "one of the objects and purposes of the law"); Hewitt, 33 Mass. (16 Pick.) at 355-56 (stating that laws which have the "effect" of conferring special benefits on certain persons are not invalid, so long as that effect is "incidental, and not one of the purposes" of the law.))

${ }^{117}$ Barbier v. Connolly, 113 U.S. 27, 31 (1885).

${ }^{118} I d$. at 32.

${ }^{119}$ Id. at 31-32.

${ }^{120}$ See Budd v. State, 22 Tenn. (3 Hum.) 483 (1842) (special criminal law applicable only to employees of a certain bank); see also Ward v. Barnard, 1 Aik. 121 (Vt. 1825) (a creditor challenged a law granting a debtor a special right to release from debtor's jail without paying back his debt); Reed v. Wright, 2 Greene 15, $27-28$ (Iowa 1849) (a halfbreed Indian challenged a law singling out halfbreed Indians for special disadvantage as land owners and attempting to recover property); Lewis $v$. Webb, 3 Me. 326 (1825) (adversely affected party challenging a law granting certain person a special right to appeal financial obligations between adverse parties); Jones' Heirs v. Perry, 18 Tenn. (10 Yer.) 59 (1836) (heirs of an estate challenged a law granting guardian of certain minors a special right to sell their property); Officer v. Young, 13 Tenn. (5 Yer.) 320 (1833) (law granting a certain person a special right to prosecute an appeal in the name of a deceased person); Saunders, supra note 19, at 252, n.28. 
Opposition to class legislation had deep roots in the common law and was a fundamental principle of the Founders of this country. ${ }^{121}$ Aversion to such laws was grounded in the Lockean philosophy that government existed for the purpose of protecting private citizens' natural rights. ${ }^{122}$ And there was widespread belief that laws should have equal application to all members of society and should not be used as a means of favoring or disfavoring specific groups or individuals. As Locke put it, there should be "one Rule for Rich and Poor, for the Favourite at Court, and the Country Man at Plough."123

\section{a. Evidence from the common law and the founding}

Even before the Founding in 1789, some states banned class legislation in their state declarations of rights or bills of rights. ${ }^{124}$ For instance, Virginia's Declaration of Rights of 1776 prohibited the granting of "exclusive or separate Emoluments or Privileges from the Community, but in Consideration of public Services." 25 James Madison articulated the pervasive belief of the Founders that government should be "neutral between different parts of the Society," that "equality ... ought to be the basis of every law," and that laws should not place "peculiar burdens" on some individuals or "peculiar exemptions" on others. ${ }^{126}$

\footnotetext{
${ }^{121}$ See Saunders, supra note 19, at 255-256; see also Yudof, supra note 21, at 1374-1377

${ }^{122}$ See JOHN LOCKE, Two TREATIES OF GOVERNMENT §§ 123-24 (describing how "[t] Mens uniting into Commonwealths, and putting themselves under Government, is the Preservation of their Property ... their Lives, Liberties, and Estates") [hereinafter "Two TREATIES"]; BLACKSTONE's COMMENTARIES, supra note 60 , ("The principal aim of society is to protect individuals in the enjoyment of those absolute rights, which were vested in them by the immutable laws of nature; but which could not be preserved in peace without ... mutual assistance.").

${ }^{123}$ TwO TREATIES, supra note $122, \S 142$.

${ }^{124}$ See Philip A. Hamburger, Equality and Diversity: The Eighteenth-Century Debate about Equal Protection and Equal Civil Rights, 8 Sup. Ct. Rev.295, 346 (1992).

${ }^{125}$ VA. DECLARATION OF RIGHTS OF 1776, § 4; Hamburger, supra note 124, at 346 n.124.

${ }^{126}$ Saunders, supra note 19, at 256. Saunders also references the position of Jeffersonian Republicans that government should provide "equal rights for all, special privileges for none," as well as the position of the Maine Whigs in the 1830s who advocated "[e]qual rights, equal laws, and equal privileges for all classes of the community." (citations omitted)
} 
Later generations recognized that one of the Founders' primary goals was to abolish class

legislation and to form a government dedicated to providing for all of its citizens. As

Representative Stephen L. Mayham said in 1870:

... when this Constitution was adopted there was no sentiment that was more universal in this nation than that of condemnation of all monopolies and privileged classes. It was to rid themselves of enormous and oppressive monopolies in the way of taxation and stamp duties that the colonists had severed their connection with Great Britain; and it was in the interest of equality and freedom of commerce, as well as freedom of person, that this Government was founded. It would be a slander upon the intelligence and patriotism of our fathers to say that this provision of the Constitution, which is the only one under which this doctrine of protection is claimed, intended it to foster monopolies and create invidious distinctions of caste based upon business or wealth. ${ }^{127}$

Senator James W. Nye similarly said in 1866:

Our forefathers were made to chafe under monarchical insult and imposition. They learned to know by experience that common protection would never be awarded by privileged class. They entered into the contest in defense of their natural and inalienable rights, and made the cause of popular justice in the strength and ennobling feature of the conflict. ${ }^{128}$

And Representative Owen Lovejoy said in 1860:

The object of government, according to the theory of the revered sages who organized this Republic, is a very simple one, namely, to protect the people in the peaceful enjoyment of their natural rights. In other words, it is a mutual pledge, each to all and all to each, to secure this result; designating the modes in which this end shall be achieved. Consequently, pensions, bounties, peculiar privileges, class legislation, and monopolies, sought from Government, is for one portion of the people to become beggars or vampires of the rest. For classes thus to beleaguer Government is as disgraceful to communities as it is to individuals ... ${ }^{129}$

In his constitutional treatises, Thomas Cooley wrote extensively that the Constitution of

1787 contained a broad ban on class legislation that applied to both the federal government and

\footnotetext{
${ }^{127}$ Cong. Globe, 41St Cong., 2ND SESSiON ApP. 180 (1870) (Speech by Representative Stephen L. Mayham) (discussing the merits of a tariff).

${ }^{128}$ Cong. Globe, 39Th Cong., 1ST Sess. 1071 (1866) (Statement of Sen. James W. Nye). Nye also condemned the conduct of southern states: "In the recent attempt at revolution the intended perpetuity of human bondage, added to the intended monopoly of wealth and political power, were the mainspringings of the rebellion." Id.

${ }^{129}$ Cong. GlOBE, 36TH CONG., SpeCiAL SESS. 174-175 (1860) (Speech by Representative Owen Lovejoy).
} 
the states. ${ }^{130}$ For one, Cooley saw “implied restrictions" on Congress' taxing power in Article I Section $8,{ }^{131}$ which states, "The Congress shall have Power To lay and collect Taxes, Duties, Imposts and Excises, to pay the Debts and provide for the common Defence and general Welfare of the United States; but all Duties, Imposts and Excises shall be uniform throughout the United States." 132 As he said, "a tax can have no other basis than the raising of a revenue for public purposes, and whatever governmental exaction has not this basis is tyrannical and unlawful.... Where, however, a tax is avowedly laid for a private purpose it is illegal and void." ${ }^{, 133}$ But Cooley also said that these "implied restrictions" applied to all the Article I, Section 8 powers, and not just to the taxing power: ${ }^{134}$ "Every legislative body is to make laws for the public good, and not for the benefit of individuals; and it is to make them aided by the light of those general principles which lie at the foundation of representative institutions. ${ }^{135}$ Cooley also said that the Just Compensation Clause of the Fifth Amendment embodied this public purpose doctrine. Inherent in the "underlying principle of the law of eminent domain," is the government's power "to control and regulate those rights of a public nature which pertain to its citizens in common, and to appropriate and control individual property for the public benefit, as the public safety, necessity, convenience, or welfare may demand." ${ }^{, 136}$ Tying together congressional power to tax and take property, Cooley explained that " $[t]$ axation takes property from the citizen for the public use, but it does so under general rules of apportionment and uniformity, so that each citizen is supposed to contribute only his fair share to the expenses of government, and to be

\footnotetext{
${ }^{130}$ See ThOMAS COOLEY, GENERAL PRINCIPLES OF CONSTITUTIONAL LAW (1880) [hereinafter "GENERAL PRINCIPLES"].

${ }^{131} I d$. at 58-60, 98.

${ }^{132}$ U.S. CONST. art. I, § 8, cl. 1 (emphasis added).

${ }^{133}$ GENERAL PRINCIPLES, supra note 130, at 57-58.

${ }^{134}$ Cooley's assertion is bolstered by some of the language in Article I Section 8, which allows Congress "[t]o establish an uniform Rule of Naturalization, and uniform Laws on the subject of Bankruptcies throughout the United States.” U.S. CONST. art I, § 8, cl. 4 (emphasis added).

${ }_{135}^{13}$ See Id. at $97-98$.

${ }^{136} I d$. at 332.
} 
compensated for doing so in the benefits which the government brings him." ${ }^{, 137}$ In contrast, eminent domain takes a specific piece of property from an individual and utilizes just compensation as a means of "equalization." 138 In his section on contract and property rights, Cooley also said that the Contracts Clause banned class legislation passed by the states, describing how the Clause only allows regulation of contracts for a public purpose. ${ }^{139}$ Cooley also described how the Constitution banned monopolies: "exclusive privileges are to some extent invidious and very justly obnoxious, and it is not reasonable to suppose that the State would grant them, except when some important public purpose or some necessary public convenience cannot be accomplished or provided without making the grant exclusive." ${ }^{140}$ A state could only grant an exclusive privilege that served a public purpose, such as for building a bridge. ${ }^{141}$

Several other constitutional provisions further support Cooley's view that the 1787 Constitution banned class legislation. For instance, the Preamble declares that the purpose of the Constitution is to "provide for the common defence" and "promote the general Welfare."142 And the Full Faith and Credit Clause only allows Congress to pass "general laws." ${ }^{143}$ Bans on bills of attainder and ex post facto laws in Article I Sections 9 and 10 perhaps were also designed to protect against class legislation. As discussed below, the religion clauses also banned class legislation at least with respect to religion. ${ }^{144}$ The Establishment Clause prevented the government from granting a special monopoly to one religion; and the Free Exercise and No

\footnotetext{
${ }^{137}$ Id. at 333 .

${ }^{138}$ Id. at 334.

${ }^{139}$ See Id. at 310-311.

${ }^{140} \mathrm{Id}$. at 306 . Cooley does not specify which constitutional provision bars the states from granting monopolies, but he seemed to find the prohibition in the Contracts Clause.

${ }^{141} \mathrm{Id}$. at 235-236, 306.

142 U.S. CONST. pmbl. (emphasis added).

${ }^{143}$ U.S. CONST. art. IV, $§ 1$ ("Full Faith and Credit shall be given in each State to the public Acts, Records, and judicial Proceedings of every other State. And the Congress may by general Laws prescribe the Manner in which such Acts, Records and Proceedings shall be proved, and the Effect thereof.")

${ }^{144}$ See infra Part II.B.
} 
Religious Test Clauses barred the government from subjecting those who were religious to unique burdens. So Cooley's position that the Constitution banned class legislation starting in 1787 is well grounded in constitutional text.

\section{b. Evidence from state constitutions around the time of the Founding}

Around the time of the Founding, several states had incorporated various bans on caste and class legislation into their state constitutions. ${ }^{145}$ These provisions show that opposition to caste and class legislation has been strong since the Founding. These state constitutional provisions banning class legislation lend support to Cooley's view that the federal Constitution may also have originally banned all federal class legislation. Alternatively, these clauses could indicate that the states thought that they had to include these protections in their state constitutions because the federal Constitution did not ban class legislation in contradiction to Cooley. Either way, these provisions demonstrate the deep-rooted opposition to class legislation in American history in the 1770's and 1780's.

In 1787, three states, Massachusetts, North Carolina, and Virginia, explicitly banned feudalism, which is a quintessential form of class and caste in their state constitutions. ${ }^{146}$ These states comprised twenty-three percent of the total number of states and forty-three percent of the national population in $1787 .{ }^{147}$ The provisions banning feudalism specifically evoked the language of class legislation and systems of caste, and these provisions declared hereditary privileges impermissible and they foreshadowed the Fourteenth Amendment's ban on caste and class legislation. For instance, Massachusetts's constitution said that:

\footnotetext{
${ }^{145}$ See generally, Steven G. Calabresi, Sarah E. Agudo, \& Kathryn L. Dore, State Bills of Rights in 1787 and 1791 : What Individual Rights Are Really Deeply Rooted in American History and Tradition?, 96-103 (forthcoming, 2012) (on file with authors).

${ }^{146}$ See Id. at 100.

${ }^{147}$ Id.
} 
"No man, nor corporation, or association of men, have any other title to obtain advantages, or particular and exclusive privileges, district from those of the community, than what arises from the consideration of services rendered to the public; and this title being in nature neither hereditary, nor transmissible to children, or descendants, or relations by blood, the idea of a man born a magistrate, law-giver, or judge, is absurd and unnatural."

By 1790, eight states, including Georgia, Maryland, Massachusetts, North

Carolina, New Hampshire, Pennsylvania, South Carolina, and Virginia, had provisions in their state constitutions banning the granting of titles of nobility. ${ }^{149}$ These states comprised forty-six percent of the number of states and fifty-seven percent of the total population. ${ }^{150}$ Once again, these provisions used the language of caste and class legislation in targeting hereditary rights as being especially repugnant. For instance, Maryland's constitution read, "That no title of nobility, or hereditary honours, ought to be granted in this State." ${ }^{151}$ And New Hampshire's constitution similarly declared, "No office or place whatsoever in government, shall be hereditary - the abilities and integrity requisite in all, not being transmissible to posterity or relations." $" 152$

By 1791, three states, Massachusetts, Pennsylvania, and Vermont, had broad equality guarantees in their state constitutions. ${ }^{153}$ These states constituted twenty-one percent of the states and comprised twenty-four percent of the population. ${ }^{154}$ These equality provisions guaranteed that laws could only be enacted if they would benefit the

\footnotetext{
${ }^{148}$ See, e.g., MASS. CONST. of 1780, Part 1, art. 6; see also NC DECL. OF RIGHTS OF 1776, § 22 ("That no hereditary emoluments, privileges or honors ought to be granted or conferred in this State"); VA DECL. OF RIGHTS OF 1776, $\$ 4$ ("That no man, or set of men, are entitled to exclusive or separate emoluments or privileges from the community, but in consideration of public services; which, not being descendible, neither ought the offices of magistrate, legislator, or judge to be hereditary").

${ }^{149}$ See Calabresi, Agudo, \& Dore, supra note 145, at 101-102.

${ }^{150} I d$.

151 See, e.g., MD DECL. OF RIGHTS, § 40.

${ }^{152}$ NH CONST. of 1784.

${ }^{153}$ See Calabresi, Agudo, \& Dore, supra note 145, at 96-97; Delaware also had an equality guarantee which was concerned with class legislation directed against Christians. See DE DECL. OF RIGHTS, § 3 ("That all persons professing the Christian religion ought forever to enjoy equal rights and privileges in this state, unless, under colour of religion, any man disturb the peace, the happiness or safety of society.")

${ }^{154}$ See Id., at 96-97.
} 
population as a whole and if they did not single out specific groups for special burdens or privileges. For instance Vermont's constitution stated that: “...it is our indispensable duty to establish such original principles of government as will best promote the general happiness of the people of this State, and their posterity, and provide for future improvements, without partiality for, or prejudice against, any particular class, sect, or denomination of men whatever." 155 Invoking the language of class legislation, these provisions further show the deeply rooted opposition to class legislation in this country.

\section{c. Evidence from the Antebellum Period}

During the Antebellum Period, widespread opposition to class legislation was also found in state-level bans on special and partial laws. ${ }^{156}$ As the Maine Supreme Court said, "it can never be within the bounds of legitimate legislation to enact a special law ... granting a privilege and indulgence to one man" that is not granted to "all other persons." ${ }^{157}$ Instead, laws should be "prescribed for the benefit and regulation of the whole community" because all individuals have "an equal right" to their "protection." ${ }^{, 158}$ Chancellor Kent similarly wrote in 1816 that laws should "have a general and equal application" and should be "impartial in the imposition[s] which [they] create."159 States pragmatically recognized that permitting explicit favoritism or discrimination would undermine the democratic process and encourage corruption in government. ${ }^{160}$ Such an un-democratic system would favor the powerful and politically-

\footnotetext{
155 See, e.g, VT. CONST. of 1786, Pmbl; PA. CONST. 1776, DECLARATION OF RIGHTS $\S 8$ ("That every member of society hath a right to be protected in the enjoyment of life, liberty and property, and therefore is bound to contribute his proposition towards the expence of that protection, and yield his personal service when necessary, or an equivalent thereto.")

${ }_{156}$ See generally Saunders, supra note 19, at 251-268.

${ }^{157}$ Lewis v. Webb, 3 Me. 326, 336 (1825).

${ }^{158}$ Id. at 335.

${ }^{159}$ WILliam Kent, MemoIRS AND LetTERS OF JAMES KENT, LL.D 163 (1898) (quoting from an opinion Kent wrote in 1816 in his capacity as a member of the Governor's Council of Revision); Saunders, supra note 19, at 259.

${ }^{160}$ See, e.g., Ward v. Barnard, 1 Aik. 121, 123 (Vt. 1825) (argument of counsel) ("If the legislature have power to select any individual, as the object of particular legislation, and exempt him from obligations to which all others are
} 
connected and disadvantage unpopular minorities. ${ }^{161}$ As the Supreme Court of Massachusetts said, "[i]t is manifestly contrary to the first principles of civil liberty and natural justice ... [that] any one citizen should enjoy privileges and advantages which are denied to all others under like circumstances." 162 Courts also questioned whether it was constitutional to bar individuals from holding public office based on their political views. ${ }^{163}$ Instead, most agreed that the best way to protect minorities and society as a whole was through generally applicable laws that did not confer special privileges or burdens on certain groups. The Pennsylvania Supreme Court explained that when "general laws are enacted, which bear ... on the whole community, if they are unjust and against the spirit of the constitution, the whole community will be interested to procure their repeal."164 This obviously would not be the case where special or partial laws burdened only a few. Political groups, such as the Maine Whigs, also argued for "[e]qual rights, equal laws, and equal privileges for all classes of the community.",165

Andrew Jackson and his followers spoke out especially strongly in opposition to class legislation politically at the national level in the 1830s. As Jackson put it, government should

subject, it may be the instrument of the grossest favoritism; or, in times of political excitement, of the most cruel persecution"); Durkee v. City of Janesville, 28 Wis. 464, 470 (1871) (discussing how class legislation would "open[ ] the door to the greatest corruption, partiality, and favoritism").

${ }^{161}$ See e.g., Wally's Heirs v. Kennedy, 10 Tenn. 554, 557 (1831) (arguing that allowing the majority to exempt itself from generally applicable laws would permit it to become "a many-headed tyrant, with capacity and power to oppress the minority at pleasure" by enacting "odious laws binding [only] on the latter"); Vanzant $v$. Waddel, 10 Tenn. 260, 270-271 (1829) (Catron, J., concurring) (arguing that allowing the legislature to "mak[e] laws whereby are swept away the life, liberty and property of one or a few citizens, by which neither the representatives nor their other constituents are willing to be bound, is too odious to be tolerated in any government where freedom has a name"); see also William Leggett, Editorial, Monopolies, N.Y. EvenING Post, Nov. 29, 1834 ("[A]ll acts of partial legislation are undemocratic, ... and, in their final operation, [will] build up a powerful aristocracy, and overthrow the whole frame of democratic government.").

${ }^{162}$ Holder v. James, 11 Mass. 396 (1814).

${ }^{163}$ See Mayor of Baltimore v. State ex rel. Bd. of Police, 15 Md. 376, 484 (1860); Constitutional Limitations, supra note 100, at 390-391 (3d ed. 1874).

${ }^{164}$ Ervine's Appeal, 16 Pa. 256, 268 (1851); see also Bank of the State v. Cooper, 10 Tenn. (2 Yer.) 599, 606 (1831) (Green, J.) ("[T]he minority are safe, [if] the majority, who make the law, are operated on by it equally with others.")

${ }^{165}$ What the Whigs Want, BANGOR DAILY WHIG AND COURIER, Sept. 3, 1839, at 16. 
"confine itself to equal protection, and, as Heaven does its rains, shower its favors alike on the high and the low, the rich and the poor." ${ }^{166}$ Although "[d]istinctions in society will always exist under every just government," for "[e]quality of talents, of education, or of wealth can not be produced by human institutions," government should not pass laws that "add . . . artificial distinctions" to the "natural . . . advantages" that some individuals have over others. ${ }^{167}$ Perhaps most famously, Jackson vetoed the re-charter of the Second National Bank of the United States, which he viewed as being a quintessential special law. ${ }^{168}$ Jackson thought the bank was a monopoly because of its significant role in the economy and because no other banks were permitted to operate under a federal government charter of incorporation. Jackson argued that the Constitution only permitted Congress to grant monopolies in very limited situations, such as for patents and copyrights. And he believed that without an explicit textual provision like the Patents and Copyrights Clause, Congress lacked the power to grant monopolies even for patents and copyrights. In his message vetoing the renewal of the Bank's charter, Jackson wrote that:

Every act of Congress, therefore, which attempts by grants of monopolies or sale of exclusive privileges for a limited time, or a time without limit, to restrict or extinguish its own discretion in the choice of means to execute its delegated powers is equivalent to a legislative amendment of the Constitution, and [is] palpably unconstitutional. ${ }^{169}$

Jackson thought government created monopolies, such as the Bank of the United States, were violations of Locke's principles of equality:

Many of our rich men have not been content with equal protection and equal benefits, but [they] have besought us to make them richer by act of Congress. By attempting to gratify their desires we have in the results of our legislation arrayed

\footnotetext{
${ }^{166}$ A COMPILATION OF THE MESSAGES AND PAPERS OF THE PRESIDENTS: 1789-1897, at 1153 (James D. Richardson ed., 1896) [hereinafter “MESSAGES AND PAPERS OF THE PRESIDENTS”].

${ }^{167} I d$.

168 J. R. POLE, The Pursuit OF EQUALITY IN AMERICAN HiSTORY 145 (1978) (quoting Jackson)). Jackson also said at the time that government should not add "artificial distinctions" by seeking "to grant titles, gratuities, and exclusive privileges, to make the rich richer and the potent more powerful;" Yudof, supra note 21, at 1376.

${ }^{169}$ President Jackson's Veto Message Regarding the Bank of the United States (July 10, 1832), available at http://avalon.law.yale.edu/19th_century/ajveto01.asp.
} 
. . . interest against interest, and man against man, in a fearful commotion which threatens to shake the foundations of our Union. ... . If we can not at once, in justice to interests vested under improvident legislation, make our Government what it ought to be, we can at least take a stand against all new grants of monopolies and exclusive privileges, against any prostitution of our Government to the advancement of the few at the expense of the many ... ${ }^{170}$

Jackson therefore encouraged people to "take a stand against all new grants of monopolies and special privileges, against the prostitution of our Government to the advancement of the few at the expense of the many." ${ }^{171}$ It is notable that Jacksonian equal protection was confined to economic or social class legislation, such as state-granted monopolies, and did not encompass class legislation that discriminated on the basis of race. ${ }^{172}$

Many Nineteenth Century state constitutions explicitly prohibited class legislation. By 1868 , thirteen out of thirty seven states had provisions in their state constitutions that effectively barred special or partial laws. ${ }^{173}$ A typical provision read, "No law shall be passed granting to any citizen or class of citizens privileges or immunities which, upon the same terms, shall not equally belong to all citizens." ${ }^{174}$ In states where state constitutions lacked such explicit language, courts used other broadly worded provisions to strike down special and partial laws. ${ }^{175}$ Thomas Cooley documented numerous state court decisions invalidating special and partial laws based on their respective state constitutions. ${ }^{176}$ Cooley said that the widely-held, fundamental precept of state constitutional law was that "[t]hose who make the laws 'are to govern by promulgated, established laws, not to be varied in particular cases, but to have one rule for rich

\footnotetext{
${ }^{170} I d$.

${ }^{171} I d$.

172 See Yudof, supra note 21, at 1379-1380.

${ }^{173}$ See Calabresi \& Agudo, supra note 37, at 97.

${ }^{174}$ OR. CONST. of 1857 , art. I, $\$ 21$.

${ }^{175}$ See Saunders, supra note 19, at 258 (citing state court cases using provisions such as "no man, or set of men, are entitled to exclusive or separate emoluments or privileges from the community, but in consideration of public services," separation-of-powers provisions, and "law of the land" or "due process" clauses.

${ }^{176} I d$. at $259-260$.
} 
and poor."177 Cooled explained, "Equality of rights, privileges, and capacities unquestionably should be the aim of the law,' because '[s]pecial privileges are always obnoxious, and discriminations against persons or classes are still more so."178

There is also significant evidence that opposition to class legislation played a crucial role in the political fight against slavery. Although slavery certainly should have been recognized as violating bans on special or partial laws, many state courts rejected challenges to slavery, ${ }^{179}$ and many politicians as well were unsympathetic to the disfavored status of African-Americans. ${ }^{180}$ Instead, many abolitionists successfully argued that slave holders represented a powerful special interest group that had seized control of the government, potentially undermining the republic's stability. ${ }^{181}$ These abolitionists specifically avoided arguing that slavery was immoral or that whites should empathize with the plight of the slaves. ${ }^{182}$ The argument was based on political power, and it appealed to a wide variety of political groups who worried about the economic, social, and political consequences of special and partial laws and who recognized that government should simply not be in the business of picking favorites. ${ }^{183}$ This approach to

\footnotetext{
${ }^{177}$ CONSTitutional Limitations, supra note 100, at 392; see also Id. ("[E]very one has a right to demand that he be governed by general rules, and a special statute which ... singles his case out as one to be regulated by a different law from that which is applied in all similar cases, would not be legitimate legislation.").

${ }^{178}$ Id. at 393; see also People v. Township Bd. of Salem, 20 Mich. 452, 486 (1870) (Cooley, J.) ("discrimination by the State between different classes ... and the favoring of one at the expense of the rest ... is not legitimate legislation, and is an invasion of that equality of right and privilege which is a maxim in State government."). ${ }^{179}$ See, e.g., Jackson v. Bulloch, 12 Conn. 38, 42-43 (1837) (holding that the "no exclusive privileges" provision in the Connecticut Constitution did not outlaw slavery); Roberts v. City of Boston, 59 Mass. (5 Cush.) 198, 209-10 (1849) (refusing to strike down racial segregation in the public schools based on the equality provision of the Massachusetts Constitution); State v. Manuel, 20 N.C. (Dev. \& Bat.) 144, 163-64 (1838) (holding that the "law of the land" and "no exclusive privileges" clauses of the North Carolina Constitution did not protect Blacks from special criminal penalties); Saunders, supra note 19, at 264 n.80.

${ }^{180}$ See Saunders, supra note 19, at 264-265 (citing Jacksonian Democrats' opposition to blacks' equality).

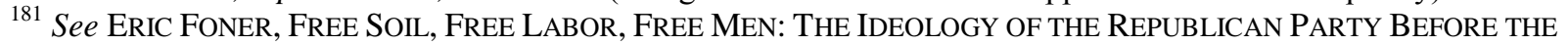
CIVIL WAR 73-74, 87-102 (1970).

${ }^{182} I d$. at 99.

${ }^{183}$ Id. at $163-169$.
} 
abolition became a unifying force for the Republican Party and attracted defectors from other

political affiliations, such as Jacksonians, who objected to class legislation. ${ }^{184}$

Debates over slavery often invoked the language of class legislation and caste. For

instance, Representative Norton Townshend said in 1852:

I protest against all these interpolations into the Democratic creed, and against any such interpretation of Democracy as makes it the ally of slavery and oppression. Democracy and slavery are directly antagonistic. Democracy is opposed to caste, slavery creates it; Democracy is opposed to special privileges; slavery is but the privilege specially enjoyed by one class-to use another as brute beasts and take their labor without wages; Democracy is for elevating the laboring masses to the dignity of perfect manhood; slavery grinds the laborer into the very dust ... slavery is but the extreme of class legislation . . . slavery is nothing more than the privilege some have of living out of others ... ${ }^{185}$

Representative John F. Farnsworth also said, "As a moral being, as a man, I hate slavery in the

States of this Union as I hate serfdom in Russia--which, by the way, is about to be abolished in that Empire, while we are quarrelling over the extension of slavery in this-just as I hate caste in India- just as I hate oppression everywhere. ${ }^{186}$ President Andrew Johnson later described slavery as a "monopoly." 187 Even supporters of slavery recognized that slavery constituted a caste system. Senator Lewis Cass said:

\footnotetext{
${ }^{184} \mathrm{Id}$. at $163-169$.

${ }^{185}$ Cong. Globe, 32ND CONG., 1ST SESS., APP. 713 (1852) (statement of Norton S. Townshend).

${ }^{186}$ Cong. Globe, 36Th Cong., SpeCial SeSs. 120 (1861) (Statement of Representative John F. Farnsworth); see also Cong. Globe, 34TH Cong., 3RD SESS., App. 230 (1857) (statement of Lemuel D. Evans) (“ . . servitude of caste, which is collective slavery ..." ); CONG. GLOBE, 33RD CONG., 1ST SESS., APP. 769 (1854) (Statement of Representative Seward) (contrasting the lack of slavery in Europe with the existence of slavery in the United States and stating, " . . . the slavery of caste, like African slavery. Such slavery tends to demoralize equally the subjected race and the superior one.")

${ }^{187}$ Cong. Globe, 39Th Cong., 1St SESS., 3 (1866) (Message of President Andrew Johnson) ("Slavery was essentially a monopoly of labor, and as such locked the States where it prevailed against the incoming of free industry. Where labor was the property of the capitalist, the white man was excluded from employment, or had but the second best chance of finding it; and the foreign emigrant turned away from the region where his condition would be so precarious. With the destruction of the monopoly, free labor will hasten from all parts of the civilized world to assist in development various and immeasurable resources which have hitherto lain dormant ... The removal of the monopoly of slave labor is a pledge that those regions will be peopled by a numerous and enterprising population, which will vie with any in the Union.")
} 
"Between three and four millions of people, differing in race and color from the pre-dominant caste, are held in bondage. I have seen a good deal of slavery, and I believe its evils are much magnified, and that the slaves generally in our southern States are treated with as much kindness and consideration as are compatible with their relative condition of bond and free."

After slavery was abolished, many recognized that the mistreatment of blacks was not merely a problem of racial animus but was part of a much larger problem of class legislation.

Senator Sumner summarized the widespread mood in 1866 in discussing the mistreatment of blacks in the South:

"The pretension thus organized is hateful on another ground. It is nothing less than a Caste, which is at once irreligious and un-republican. A Caste cannot exist except in defiance of the first principles of Christianity and the first principles of a Republic. It is Heathenism in religion and tyranny in government. The Brahmins and the Sudras in India, from generation to generation, have been separated, as the two races are now separated in these States. If a Sudra presumed to sit on a Brahmin's carpet he was punished with banishment. But our recent rebels undertake to play the part of Bramhins, and exclude citizens, with better title than themselves, from essential rights, simply on the ground of Caste, which, according to its Portuguese origin, caste, is only another term for race. But this pretension is in yet other respects hostile to good government. It is essentially a Monopoly in a country which sets its face against all monopolies as unequal and immoral. If any monopoly deserves unhesitating judgment it must be that which absorbs the rights of others and engrosses political power. How vain it is to condemn the petty monopolies' of commerce and then' allow this vast, allembracing monopoly of Human Rights. Clearly, most clearly, and beyond all question, such a government cannot he considered a republican in form." Call it an Oligarchy, call it an Aristocracy, call it a Caste, call it a Monopoly; but do not call it a Republic." 189

Senator Sumner clearly equated the caste-style mistreatment of African-Americans to the burdens of government-granted monopoly power to favored groups or businesses. Granting a government monopoly license, or enacting any other type of economic class legislation, was therefore no different from the Indian caste system or the mistreatment of African-Americans in this country. Sumner's rhetoric was likely intended to persuade dissenters that African

\footnotetext{
${ }^{188}$ Cong. Globe, 31st Cong., 1St SeSs. 399 (1850) (Statement of Senator Lewis Cass).

${ }^{189}$ CONG. Globe, 39TH CONG., 1ST SESS. 683-684 (1866) (Statement by Senator Charles Sumner).
} 
Americans deserved the same equal right to be free of class legislation that white Americans enjoyed. So Sumner compared the mistreatment of African Americans to the mistreatment of oppressed groups in other legal systems that everyone understood as unjust - namely, the Indian caste system and government grants of monopoly. Although comparing a government-granted monopoly to a caste system might sound odd to modern ears, in the Nineteenth Century government grants of monopoly were widely viewed as being antithetical to democracy and as being a throwback to Bad King George. For this reason, Sumner could credibly say:

The Rebellion began in two assumptions, both proceeding from South Carolina: first, the sovereignty of the States, with the pretended right of secession; and secondly, the superiority of the white race, with the pretended right of Caste, Oligarchy, and Monopoly, on account of color. ${ }^{190}$

Similarly, President Andrew Johnson decried the Black Codes because " there is no room for favored classes or monopolies,' for 'the principle of our Government is that of equal laws,' which 'accord equal justice to all men, special privileges to none.",191

In the years leading up to 1868 , there was widespread support for abolishing class legislation, not simply constitutionalizing the ban on racial discrimination from the Civil Rights Act of 1866. An editorial in the Chicago Tribune in January 1866 explained that the Black Codes were a repugnant, aristocratic form of class legislation contrary to American values:

We have seen, through bitter experience, the evils of class legislation as practi[c]ed by the States, in the form of slave and black codes. We cannot but perceive the evils of the system in England, and all monarchical governments, where the laws are allowed to recognize distinctions between persons and classes ... And if the several States can practi[c]e class legislation, as between whites and blacks ... they can also create class distinctions in the future between native and adopted citizens, between rich and poor, or between any other divisions of society. The most effectual way to reach the root of this matter, is to amend the Constitution so as to forbid class legislation entirely by prohibiting the enactment of laws creating or recognizing any political distinctions because of class, race or

\footnotetext{
${ }^{190}$ Id. at 684.

1912 MESSAGES AND PAPERS OF THE PRESIDENTS, supra note 158, at 361-62 (emphasis added); Saunders, supra note 19 , at 272 .
} 
color between the inhabitants of any State or Territory, and providing that all classes shall possess the same civil rights and immunities, and be liable to the same penalties, and giving Congress the power to carry the clause into effect. . . [W]e believe that we might as well level the evil of caste at one blow, as to fight it by driblets and sections, through another long course of years. ${ }^{192}$

The editorial's rhetoric clearly goes well beyond a call merely for the ending racial discrimination. Similarly, in February 1866 the North American Gazette described how Congress was discussing a constitutional amendment that would "secure for the citizens of any one State the same rights as are enjoyed by the citizens of other States, thus terminating the discriminations made against sections and classes and races." 193 The view was, as James Wilson, Chair of the House Judiciary Committee and sponsor of the Civil Rights Act of 1866, put it, that in democratic government there is "no class legislation, no class privileges," and no laws that can be directed "against [one class] for the purpose of advantaging the interests of [another]."194 Senator Sumner explained how banning class legislation effectively enforced the Thirteenth Amendment's abolition of slavery:

You have, sir, decreed that colored persons shall enjoy the same civil rights as white persons; in other words, that, with regard to civil rights, there shall be no Oligarchy, Aristocracy, Caste, or Monopoly,' but that all shall be equal before the law without distinction of color. And this great decree you have made as "appropriate legislation" under the Constitutional Amendment "to enforce" the abolition of slavery." 195

So strong was opposition to class legislation in the mid-Nineteenth Century, that some attempted to read a ban on class legislation into the meaning of the Civil Rights Act of 1866, even though the text of the Act did not support such an understanding. ${ }^{196}$

\footnotetext{
${ }^{192}$ Editorial, Class Legislation, CHI. TRIB., Jan. 12, 1866, at 2.

${ }^{193}$ Constitutional Amendments, PhILA. N. AM. \& U.S. GAZETTE, Feb.15, 1866, at 1.

${ }^{194}$ Cong. Globe, 39Th CONG., 1St SeSS. 2766 (1866).

195 Cong. Globe, 39Th Cong., 1ST SESS. 684 (1866) (Statement of Charles Sumner).

${ }^{196}$ See Cong. Globe, 39Th CONG., 1St SeSs. 1760 (1866) (statement of Sen. Trumbull that the Act "declares that in civil rights there shall be an equality among all classes of citizens"). Calabresi and Rickert explain how the Act does not support this assertion. See Calabresi \& Rickert, supra note 21, at 29.
} 


\section{d. Evidence from the history of the ratification of the Fourteenth Amendment}

The legislative history shows that the framers of the Fourteenth Amendment specifically intended to abolish all forms class legislation, which certainly included slavery and discrimination on the basis of race. ${ }^{197}$ The Thirty-ninth Congress that drafted the Fourteenth Amendment was comprised largely of Republicans and of Jacksonian Democrats who fervently opposed all forms of class legislation. ${ }^{198}$ These Republicans and Jacksonian Democrats supported abolition and the guarantee of civil rights for African Americans, not necessarily out of a sense of morality or empathy for African Americans - though some framers of the Fourteenth Amendment certainly felt that way - but out of a hatred for class legislation in all its hideous forms. ${ }^{199}$ And the Reconstruction Congresses sought to constitutionalize in the federal Constitution as it applied to the states the Antebellum doctrine banning special or partial laws, which state courts had failed to use to protect African Americans.

The legislative history reveals considerable opposition to the Black Codes, not because they discriminated on the basis of race, ${ }^{200}$ but because they singled out a certain class of individuals for unique disadvantage. Senator Lyman Trumbull, the cosponsor of the Civil Rights Act of 1866, criticized the Black Codes for "depriv[ing] [some] citizen[s] of civil rights which are secured to other citizens" and violating Blackstone's maxim that "'the restraints introduced by the law should be equal to all.",201 Senator William Pitt Fessenden described the Black Codes

\footnotetext{
${ }^{197}$ Saunders, supra note 19, 269-270.

${ }^{198} \mathrm{Id}$.

${ }^{199} \mathrm{Id}$.

${ }^{200}$ See Judith A. BAER, EQUALity Under The CONSTITUTION: REClAIMING THE FourteEnTH AMENDMENT $92-93$ (1983) (pointing out that "for most speakers, what made the [Black Codes] so odious was not that [they] based classification on race as opposed to some other characteristic").

${ }^{201}$ CONG. GLOBE, 39TH CONG., 1ST SESS. 474 (1866).
} 
as being unacceptable "class legislation."202 Senator Henderson objected to the "unequal burdens" placed on freedmen. ${ }^{203}$ Many others objected that the Black Codes effectively reduced freemen to second class citizens. ${ }^{204}$ And President Andrew Johnson opposed the Black Codes because "there is no room for favored classes or monopolies," for "the principle of our Government is that of equal laws," which "accord 'equal and exact justice to all men,' special privileges to none.",205

The framers of the Fourteenth Amendment carefully drafted a final version of the Amendment that made no specific mention of race precisely so as to ensure that the Fourteenth Amendment would be understood as banning all systems of class and caste, and not just discrimination on the basis of race. The Thirty-ninth Congress explicitly considered and rejected a draft of the Amendment that merely banned racial discrimination, and not systems of caste or class. That rejected version of the Fourteenth Amendment read,

Section 1. No discrimination shall be made by any state, nor by the United States, as to the civil rights of persons because of race, color, or previous condition of servitude.

${ }^{202}$ Cong. Globe, 39th Cong., 1st SeSs. 704 (1866); see also Cong. Globe, 39th Cong., 1st Sess. H. app. 156 (1866) (statement of Rep. Delano (R-Ohio)) (referring to "unequal" and "discriminating" laws); CONG. GLOBE, 39TH CONG., 1ST SESS. 2961 (1866) (statement of Sen. Poland (R-Vt.)) (referring to "partial legislation"); The Proposed Amendment to the Constitution, N.Y. COM. ADVERTISER, Jan. 23, 1866, at 2 (referring to "class legislation").

${ }^{203}$ Cong. Globe, 39Th Cong., 1St SESS. 3034 (1866) (statement of Sen. Henderson (R-Mo.)) (arguing that Black Codes subject the freedmen to "unequal burdens").

${ }^{204}$ See Saunders, supra note 19, at 271 n.112 (citing Cong. GLOBE, 39TH CONG., 1ST SESS. 1621-22 (1866) (statement of Rep. Myers (R-Penn.)) (suggesting that Black Codes "impose by indirection a servitude which the Constitution now forbids"); CONG. GLOBE, 39TH CONG., 1ST SESS. 1151 (1866) (statement of Rep. Thayer (RPenn.)) (arguing that Black Codes are being used to "reduce this class of people to the condition of bondmen"); Cong. Globe, 39Th Cong., 1ST SESS. 1124 (1866) (statement of Rep. Cook (R-Ill.)) (arguing that the Black Codes "practically reduc[e] these men to the condition of slavery"); CONG. GloBE, 39TH CONG., 1ST SESS. 603 (1866) (statement of Sen. Wilson (R-Mass.)) (arguing that Black Codes "make slaves of men whom we have made free"); Cong. Globe, 39TH Cong., 1ST SESS. 504 (1866) (statement of Sen. Howard (R-Mich.)) (stating that Black Codes reduce the freedmen "to a condition infinitely worse than that of actual slavery"); CONG. GLOBE, 39TH CONG., 1ST SESS. 340 (1866) (statement of Sen. Wilson) (stating that Black Codes "practically make the freedman a peon or a serf”); Cong. GlOBE, 39Th CONG., 1ST SESS. 39 (1865) (statement of Sen. Wilson (R-Mass.)) (arguing that Black Codes "practically make slaves of men we have declared to be free")).

2056 MESSAGES AND PAPERS OF THE PRESIDENTS, at 361-62 (Dec. 4, 1865). 
Section 2. From and after the fourth day of July, in the year one thousand eight hundred and seventy-six, no discrimination shall be made by any state, nor by the United States, as to the enjoyment by classes of persons of the right of suffrage, because of race, color, or previous condition of servitude.

Sec. 3. Until the fourth day of July, one thousand eight hundred and seventy-six, no class of persons, as to the right of any of whom to suffrage discrimination shall be made by any state, because of race, color, or previous condition of servitude, shall be included in the basis of representation. ${ }^{206}$

Notably, this version used the language of class legislation ("classes of persons" in Section Two and "class of persons" in Section Three), but the scope of the ban on class legislation was limited to a ban on discrimination on the basis of race, color, and previous condition of servitude. The new and final version rejected this narrow ban and instead forbade all caste and class legislation.

And members of the Thirty-ninth and Fortieth Congresses understood that the objective public meaning of the final version of the Fourteenth Amendment was that the Amendment broadly banned all forms of caste and class legislation, and not just laws that discriminate on the basis of race. Senator Jacob Howard said that the Amendment "abolishes all class legislation in the States and does away with the injustice of subjecting one caste of persons to a code not applicable to another." ${ }^{207}$ Representative Thomas Eliot said the Amendment would "prohibit State legislation discriminating against classes of citizens." ${ }^{208}$ Representative Hotchkiss described the Amendment as having been constructed to ban "discriminat[ion] between its citizens and [all laws that] give one class of citizens greater rights than it confers upon another. ${ }^{209}$ Senator Timothy Howe said that the Fourteenth Amendment would give the federal

\footnotetext{
${ }^{206}$ See Calabresi \& Rickert, supra note 21, at 32 (citing BENJ. B. KENDRICK, THE JOURNAL OF THE JoINT COMMITTEE OF FIFTEEN ON RECONSTRUCTION 83-84 (1914) for the text of the proposed amendment and referencing statements made by Senator Sumner that the proposed amendment's scope was too narrow).

${ }^{207}$ Cong. Globe, 39Th Cong., 1St SeSS. 2511 (1866).

${ }^{208}$ CONG. GLOBE, 39Th CONG., 1st SESS. 2511 (1866).

${ }^{209}$ Cong. Globe, 39Th CONG., 1St SeSS. 1095 (1866).
} 
government "the power to protect classes against class legislation." ${ }^{, 10}$ Republicans generally

understood the Amendment as striking down feudalistic systems and aristocracy:

"But," say some, "this section is designed to coerce the South into according Suffrage to her Blacks." Not so, we reply; but only to notify her ruling caste that we will no longer bribe them to keep their blacks in serfdom. An aristocracy rarely surrenders its privileges, no matter how oppressive, from abstract devotion to justice and right. It must have cogent, palpable reasons for so doing. ${ }^{211}$

Senator Sumner also described the Amendment in broad, powerful terms:

Rights, that Slavery, with all its brood of wrong, was upheld; and it is now in the name of State rights, that Caste, fruitful also in wrong, is upheld. The old champions reappear, under other names, and from other States, each crying out, that, under the national Constitution, notwithstanding even its supplementary amendments. A State may, if it pleases, deny political rights on account of race or color and thus establish that vilest institution, a Caste and an Oligarchy of the skin. .. On these simple texts, conferring plain and intelligible powers, the champions insist that "color" may be made a "qualification;" and that, under the guise of "regulations," citizens, whose only offense is skin not colored like our own, may be shut out from political rights; and that in this was a monopoly of rights, being at once a Caste and an Oligarchy of the skin, is placed under the safeguard of the National Constitution. ${ }^{212}$

And Representative Thaddeus Stevens of Pennsylvania made it clear that the Amendment banned even non-racial class legislation: "the same laws must and shall apply to every mortal, American, Irishman, African, German or Turk" ${ }^{213}$ because "the same law which punishes one man shall punish any other for the same offense ... the law which gives a verdict to one man shall render the same verdict to another, whether he is Dutch, Irish, or Negro." 214

\footnotetext{
${ }^{210}$ Cong. GlOBE, 40TH CONG., 2D SESS. 883 (1868).

${ }^{211}$ Nat'l Republican Union Comm., Address to the American People, BANGOR DaILy WhIG \& CourIER, Sept. 22, 1866, at 1.

${ }^{212}$ Cong. Globe, 40Th Cong., 3RD SeSs. 902 (1869) (Statement of Senator Charles Sumner). Senator Sumner often invoked the language of class legislation when discussing racial equality. For instance, he used the phrase, "oligarchy of the skin," nine times on the Senate floor from 1865 to 1872. Search using HeinOnline, May 18, 2012.

${ }^{213}$ Thaddeus Stevens, The Pending Canvass!, Speech Delivered at Bedford, Pa. (Sept. 4, 1866), in THADDEuS SteVEns PAPERS 11 (Beverly Wilson Palmer ed., 1993).

${ }^{214} I d$.
} 
Popular newspapers also recognized that the Fourteenth Amendment broadly banned all class legislation and systems of caste. ${ }^{215}$ The San Francisco Daily Evening Bulletin said that the amendment served as an "opportunity ... for the masses to break down the domination of caste and aristocracy." 216 The Boston Daily Advertiser described the Amendment's purpose as "compel[ling] the States to ... throw the same shield over the black man as over the white, over the humble as over the powerful." 217 The Boston Daily Advertiser also said, "The National Union Committee put the case very well when they stated the object of the amendment of the Constitution to be, 'to notify the ruling caste of' the South that we will no longer bribe them to keep "their blacks in serfdom", 218 And the Cincinnati Commercial said that the Amendment constitutionalized "the great Democratic principle of equality before the law" and invalidated all "legislation hostile to any class." ${ }^{219}$ The Commercial added:

With this section engrafted upon the Constitution it will be impossible for any Legislature to enact special codes for one class of its citizens, as several of the reconstructed States have done, subjecting them to penalties from which citizens of another class are excepted if convicted of the same grade of offense, or confer privileges upon one class that it denies to another. ${ }^{220}$

These sources indicate that the public meaning of the Amendment was a broad ban on all class legislation and systems of caste. As Calabresi and Rickert say:

"[b]y connecting the old-world problems of aristocracy and feudalism with race discrimination and caste in America, these commentators provide more evidence that the American public conceived of the word caste at a higher level of generality than the word race. The Framers and ratifiers of the Fourteenth Amendment would have understood it to ban European feudalism or the Indian caste system, as well as the special-interest monopolies that so outraged Jacksonian Americans.",221

\footnotetext{
${ }^{215}$ See Calabresi \& Ricket at 35-36 (citing the San Francisco Daily Evening Bulletin describing the amendment as an "opportunity ... for the masses to break down the domination of caste and aristocracy.")

${ }^{216}$ Southern Experiment, S.F. DAILY EVENING Bull., Nov. 9, 1866, at 1.

${ }^{217}$ Editorial, Reconstruction, Bos. DAILY ADVERTISER, May 24, 1866, at 1.

${ }^{218}$ Boston Daily AdVERTISER, (Boston, MA) Saturday, September 22, 1866; Issue 71; col A.

219 The Constitutional Amendment, CINCINNATI COM., June 21, 1866, at 4.

${ }^{220}$ The Constitutional Amendment, CINCINNATI COM., June 21, 1866, at 4.

${ }^{221}$ Calabresi \& Rickert, supra note 21, at 36.
} 
Significantly, the Thirty-ninth Congress did not believe that laws prohibiting interracial marriage would violate the Fourteenth Amendment, even though such laws seem to clearly discriminate on the basis of race. The majority view was that antimiscegenation laws would remain valid because they did not "discriminate against" a particular race or class but applied equally to everyone. $^{222}$ The reasoning relied on a technicality, allowing antimiscegenation laws to escape the ban on class. Since under these laws whites could only marry whites and AfricanAmericans could only marry African-Americans, it was argued that antimiscegenation laws applied to the two races equally. In retrospect, this argument overlooks that antimiscegenation laws were in fact forms of class legislation singling out interracial couples for a special burden without a legitimate public purpose and in reality served as nothing more than a smokescreen for degrading African Americans and people who choose to marry African Americans. ${ }^{223}$ But the legislative history on this topic makes it clear that the principal issue was whether the laws constituted class legislation, not whether they discriminated on the basis of race.

Following ratification of the Fourteenth Amendment, members of the Congress that had produced the Amendment clearly understood that the objective public meaning of the Amendment was that it banned all forms of class legislation and all caste systems. Although some statements in the legislative history contradict Professor Harrison's understanding that the Privileges or Immunities Clause guaranteed equality in law making, and the Equal Protection Clause guaranteed that the government apply the laws equally, at the very least all the legislative

\footnotetext{
${ }^{222}$ See Saunders, supra note 19, at 275 n.126 (citing CONG. GLOBE, 39TH CONG., 1ST SESS. 505 (1866) (statements of Sen. Fessenden (R-Me.) and Sen. Trumbull (R-Ill.))).

${ }^{223}$ See Calabresi \& Matthews, supra note 30 (arguing that antimiscegenation laws violate the Fourteenth Amendment's ban on class legislation because they alter citizens' privileges and immunities based on race).
} 
history supports the notion that the Amendment as a whole banned class legislation. ${ }^{224}$ James $^{2}$ Garfield stated that the Section One of the Fourteenth Amendment barred states from "making or enforcing laws which are not on their face and in their provisions of equal application to all the citizens of the State . . like the air of heaven, covering all and resting upon all with equal weight." 225 And Senator Oliver Morton declared that the Equal Protection Clause means "that no person shall be deprived by a State of the equal benefit of the laws." ${ }^{226}$ Morton added that the Clause "was intended to strike at all class legislation, to provide that the laws must be general in their effects ... it was intended to promote equality in the States, and to take from the States the power to make class legislation and to create inequality among their people."227 Morton explained that "the word "protection," as used in the clause, "means not simply the protection of the person from violence, the protection of his property from destruction, but . . . the equal benefit of the law." 228 Senator Thayer of Nebraska declared, "For the first time in our history [the Fourteenth Amendment] struck down that prop of despotism, the doctrine of caste." ${ }^{229}$ Senator George Edmunds of Vermont also commented that the Constitution "protected a right of her citizens against class prejudice, against caste prejudice, against sectarian prejudice."230

\section{d. Evidence from after ratification of the Fourteenth Amendment}

In the years following ratification of the Fourteenth Amendment, the Supreme Court also understood that the Fourteenth Amendment had constitutionalized the Antebellum doctrine against special or partial laws. In the Slaughter-House Cases, the court dealt with a classic piece

\footnotetext{
${ }^{224}$ Of course these statements do not firmly rebut Harrison because they can be explained as the subjective misunderstanding of some Republicans during Reconstruction. See Supra p27-28 (discussing)

${ }^{225}$ CONG. GlobE, 42D Cong., 1ST SeSS. H. APP. 153 (1871); But See Saunders, supra note 19, at 290-292 (noting scholarly debate as to whether the statements of Senator Garfield and Senator Morton actually did refer to the Equal Protection Clause).

${ }^{226}$ CONG. GloBE, 42D ConG., 2D SESS. 847 (1872).

${ }^{227}$ CONG. Globe, 42D CONG., 2D SESS. 847 (1872).

${ }^{228}$ CONG. Globe, 42D ConG., 2D SESS. 847 (1872).

${ }^{229}$ CONG. GlOBE 41ST CONG., 2D SeSS., APP., 322 (1870).

230 CONG. REC. 1870 (1875).
} 
of antebellum class legislation: a monopoly. Justice Bradley's dissent dutifully identified the state-granted slaughter house monopoly as class legislation and declared it unconstitutional under the Fourteenth Amendment's equality guarantee. ${ }^{231}$ Justice Bradley wrote that "a law which prohibits a large class of citizens from adopting a lawful employment deprives those citizens of the equal protection of the laws.. ${ }^{232}$ In a follow-up case eleven years later, Justice Bradley wrote that it is a "denial of the equal protection of the laws to grant to one man, or set of men, the privilege of following an ordinary calling in a large community, and to deny it to all others. ${ }^{, 233}$ But the Slaugther-House majority was unable to accept that the framers of the Fourteenth Amendment intended to infringe on state rights so heavily. ${ }^{234}$ The only way for the majority to justify the state-granted monopoly was to declare that the clause barring governmentmandated class legislation (the Privileges or Immunities Clause) did not apply to the states. The Court's reading of the Fourteenth Amendment has been resoundingly condemned as indefensible, and we agree that the Court's reading is incorrect. ${ }^{235}$ The fact that the Privileges or Immunities Clause was excised from the Fourteenth Amendment in a case involving

${ }^{231}$ Slaughter-House Cases, 83 U.S. at 122 (Bradley, J., dissenting). ${ }^{232} I d$.

${ }^{233}$ Butchers' Union Slaughter-House and Live-Stock Landing Co. v. Crescent City Live-Stock Landing and Slaughter-House Co., 111 U.S. at 766 (Bradley, J., concurring).

${ }^{234}$ See Slaughter-house Cases 83 U.S. at 77-78 ("Was it the purpose of the fourteenth amendment, by the simple declaration that no State should make or enforce any law which shall abridge the privileges and immunities of citizens of the United States, to transfer the security and protection of all the civil rights which we have mentioned, from the States to the Federal government? And where it is declared that Congress Shall have the power to enforce that article, was it intended to bring within the power of Congress the entire domain of civil rights heretofore belonging exclusively to the States? All this and more must follow if the proposition of the plaintiffs in error be sound.... [T] he effect is to fetter and degrade the State governments by subjecting them to the control of Congress in the exercise of powers heretofore universally conceded to them of the most ordinary and fundamental character....We are convinced that no such results were intended by the Congress which proposed these amendments, nor by the legislatures of the States which ratified them.")

${ }^{235}$ See, e.g., Saenz v. Roe, 526 U. S. 489 n.1, 527 (1999) (Thomas, J., dissenting) (scholars of the Fourteenth Amendment agree "that the Clause does not mean what the Court said it meant in 1873"); Akhil Amar, Substance and Method in the Year 2000, 28 Pepperdine L. Rev. 601, 631, n. 178 (2001) ("Virtually no serious modern scholar-left, right, and center - thinks that this [interpretation] is a plausible reading of the Amendment"); Brief for Constitutional Law Professors as Amici Curiae, McDonald v. City of Chicago, 130 S. Ct. 3020, at *33 (2010) (arguing that the scholarly consensus is that the majority opinion is "egregiously wrong"). 
quintessential class legislation supports Professor Harrison's thesis that the Privileges or Immunities Clause was the section of the Fourteenth Amendment dealing with law-making and was designed to outlaw class legislation, such as monopolies.

Despite the holding in the Slaughter-House Cases, future cases indicated that the Supreme Court still understood that the Fourteenth Amendment banned class legislation. For instance, in Gulf, C. \& S.F. Ry. Co. v. Ellis, the Supreme Court struck down under the Fourteenth Amendment a state law that awarded attorneys' fees to plaintiffs injured by trains because the law subjected railroad companies to a peculiar burden not placed on other corporations or individuals. ${ }^{236}$ The Court explained that allowing states to subject "certain individuals or corporations to hostile and discriminating legislation is to make the protecting clauses of the fourteenth amendment a mere rope of sand, in no manner restraining state action." ${ }^{237}$ The Court took it for granted that the Fourteenth Amendment banned all forms of class legislation and actually cited antebellum state cases to explain its Fourteenth Amendment jurisprudence. ${ }^{238}$ The Court never contemplated that the Amendment only applied to racial classifications, and the dissenting and concurring justices did not dispute the majority's contention that the Amendment banned all class legislation. On that point, the court was unanimous.

Other Supreme Court opinions similarly understood that the Fourteenth Amendment banned all class legislation. In an oft-cited opinion, Justice Field explained that under the Fourteenth Amendment, government could "not to impose unequal or unnecessary restrictions upon any one, but to promote, with as little individual inconvenience as possible, the general

\footnotetext{
${ }^{236} 165$ U.S. 150, 165-66 (1897).

${ }^{237} \mathrm{Id}$. at 154.

${ }^{238}$ See, e.g., Gulf, Colo. \& Santa Fe Ry. v. Ellis, 165 U.S. 150, 156 (1897) (quoting Dibrell v. Morris' Heirs (Tenn.) $15 \mathrm{~S}$. W. 87, 95, Baxter, ("whether a statute be public or private general or special, in form, if it attempts to create distinctions and classifications between the citizens of this state, the basis of such classification must be natural, and not arbitrary.") and quoting Vanzant v. Waddel, 10 Tenn. (2 Yer.) 230, 270 (1829) ("Every partial or private law ... is unconstitutional and void")); see also Cotting v. Kansas City Stock Yards, 183 U.S. 79, 105 (1901) (same).
} 
good." 239 The laws must "operate alike upon all persons and property under the same circumstances and conditions" because "[c]lass legislation, discriminating against some and favoring others, is prohibited" by the Fourteenth Amendment. ${ }^{240}$ In Pollock v. Farmers' Loan \& Trust Co., the Supreme Court said that "the great amendments to the Constitution which followed the late civil war had rendered [class] legislation impossible for all future time." ${ }^{241}$ In Minneapolis \& St. Louis Ry. v. Beckwith, the majority opinion explicitly said that the Fourteenth Amendment "prohibit[s] discriminating and partial legislation by any State in favor of particular persons as against others in like condition." 242 And even in Pace v Alabama, which upheld antimiscegenation rules, the majority similarly stated that the Fourteenth Amendment "prevent[ed] hostile and discriminating State legislation against any person or class of persons." ${ }^{243}$ Even though the court at times initially indicated that the Fourteenth Amendment would not protect African Americans, ${ }^{244}$ the court soon changed course. ${ }^{245}$

In the Civil Rights Cases, the Supreme Court was unanimous in saying that the Fourteenth Amendment banned class legislation. Justice Bradley, writing for the majority, described "class legislation" as "obnoxious to the prohibitions of the Fourteenth Amendment."246 Justice Bradley explained that an example of class legislation would be a law "denying to any person, or class of persons, the right to pursue any peaceful avocations allowed to others." ${ }^{247}$ In dissent, Justin Harlan wrote, "If the constitutional amendments be enforced, according to the

${ }^{239}$ Barbier, 113 U.S. at 32.

240 Id.; Yick Wo v. Hopkins, 118 U.S. 356, 68 (1886) (citing Barbier v. Connolly as the correct explanation of the Fourteenth Amendment) Hayes v. Missouri, 120 U.S. 68, 72 (1887) (same); McPherson v. Blacker, 146 U.S. 1, 39 (1892) (same); Cotting v. Kansas City Stock Yards, 183 U.S. 79, 105 (1901).

${ }^{241} 157$ U.S. at 596-597.

242129 U.S. $26,28-29$ (1889).

243 106 U.S. 583, 584 (1882).

244 See Slaughter-House Cases, 83 U.S. at 81 ("We doubt very much whether any action of a State not directed by way of discrimination against the negroes as a class ... on account of their race, will ever be held to come within [its] purview.")

${ }^{245}$ See Holden v. Hardy, 169 U.S. 366, 382 (1898).

${ }^{246} 109$ U.S. 3, 23 (1883).

247 Id. at 23-24. 
intent with which, as I conceive, they were adopted, there cannot be, in this republic, any class of human beings in practical subjection to another class, with power in the latter to dole out to the former just such privileges as they may choose to grant."248

Riding circuit in 1882, Justice Field's opinions also discussed the Fourteenth Amendment's ban on class legislation. He wrote that the Fourteenth Amendment "stands in the constitution as a perpetual shield against all unequal and partial legislation by the states," 249 and “"that the law which operates upon one man shall operate equally upon all.,",250

The weight of the historical evidence thus suggests that the Fourteenth Amendment banned all forms of class legislation and all systems of caste. The Amendment's framers recognized the problems associated with not having such a ban, as evidenced primarily by the treatment of African-Americans up to that time. Consequently, they adopted a ban on all class legislation that had existed at the state-level since before the Founding. Under Cooley's view, the Amendment mirrored the Bill of Rights, simply articulating principles already embodied in the Constitution. As Cooley wrote,

It was not within the power of the States before the adoption of the fourteenth amendment, to deprive citizens of the equal protection of the laws; but there were servile classes not thus shielded, and when these were made freemen, there were some who disputed their claim to citizenship, and some State laws were in force which established discriminations against them. To settle doubts and preclude such laws, the fourteenth amendment was adopted; and the same securities which one citizen may demand, all others are entitled to." 251

Either way, there can be no doubt that all class legislation violated the Constitution after 1868.

\footnotetext{
${ }^{248}$ Id. at 62 (Harlan, J., dissenting).

249 County of San Mateo v. Southern Pac. R.R., 13 F. 722,741 (C.C.D. Cal. 1882) (Field, J.).

${ }^{250} \mathrm{Id}$. at 739 .

${ }^{251}$ CONSTITUTIONAL Limitations, supra note 100, at 466. Cooley also wrote in his treatise in a section entitled "unequal and partial legislation" that the Equal Protection Clause guaranteed that "the same securities which one citizen may demand, all others are entitled to." See Id. at 397. Dean Yudof also notes that Representative John Bingham from Ohio also made the same point in 1859. See Yudof, supra note 21, at 1373 n.43.
} 


\section{Religion and The Fourteenth Amendment}

\section{Religion as a Caste}

The nineteenth century definition of caste surely included discrimination on the basis of religion. As already discussed, the definition of caste was not limited to discrimination on the basis or race, national origin, or physical appearance. ${ }^{252}$ The key features of a caste system were heredity and immutability which could accompany many kinds of systems of caste ranging from European feudalism to the Indian caste system which was the paradigmatic caste system for the Framers and ratifiers of the Fourteenth Amendment in 1868. India's caste system in turn was based explicitly on religious distinctions and was not openly based on racial distinctions. Nineteenth century dictionaries cited examples of a caste as including a "class of people among the Hindoos" 253 and "the caste of [the] Bramins." ${ }^{254}$ Hinduism played an important role in structuring and enforcing the Indian caste system, although the system was not entirely grounded in Hinduism. The Brahmins were the priestly class at the pinnacle of the hierarchy and served an important religious function, providing spiritual guidance and leading religious services.

And other non-racial and religious hierarchies, such as European feudalism, the treatment of Jews in Europe prior to the French Revolution, as well as the many social distinctions that were made in Persia, Egypt, Peru, Assyria, and Attica were all recognized as being caste systems in the mid-Nineteenth Century. ${ }^{255}$ In 1872 , Senator Charles Sumner, one of the leaders of Reconstruction, remarked that:

Religion and reason condemn Caste as impious and unchristian, making republican institutions and equal laws impossible; but here is Caste not unlike that which separates the Sudra from the Brahmin. Pray, sir, who constitutes the white man a Brahmin? Whence his lordly title? Down to a recent period in Europe the

\footnotetext{
252 See supra Part II.A.

${ }^{253}$ Worcester, supra note 38, at 107-08, 128.

${ }^{254}$ Goodrich, supra note 38, at 64, 75.

${ }^{255}$ See, e.g., Sumner, supra note 38 , at 7.
} 
Jews were driven to herd by themselves separate from Christians; but this discarded barbarism is revived among us in the ban of color. There are millions of fellow citizens guilty of no offense except the dusky livery of the sun appointed by the heavenly Father, whom you treat as others have treated the Jews, as the Brahmin treats the Sudra. But pray, sir, do not pretend that this is the great Equality promised by our fathers." 256

Senator Sumner's explicit references to the mistreatment of Brahmins and Jews show that he understood that systems of caste can be based on religious distinctions. Representative Charles

Van Wyck made the same point saying that: "The meanness of caste in this country on account

of color is no more wicked than the caste of nation, religion, or blood in Great Britain." 257

The Supreme Court of New Hampshire, in a case involving the controversial theologian

Francis Abbot, discussed how classifications based on religion lead to caste:

A division of society into two ranks, a theological aristocracy on one side, a lower caste on the other,--the former wielding all the instruments of the law and all the power of the government to degrade men of the faith of Jefferson, Franklin, Ethan Allen, or Governor Plumer; commanding what doctrines shall not be preached; suppressing the freedom of the pulpit; abolishing the rights of property given to independent religious uses; and confiscating such property for the use of a state religion,--all this is as repugnant to the plain and vital principles of the constitution, as to the sense and spirit of the people who made the constitution. The governmental work of that generation has been sufficiently extolled for eighty-five years past as a triumphant vindication of human rights, affording a sure protection against ecclesiastical oppression in particular, and perpetuating throughout the state such refuge as wheelwright found for a season at Exeter in exile for conscience' sake. That work must be undone, and a degenerate age must be ready to welcome the return of the worse despotisms, before a system of religious caste can be introduced. When an infidel does not stand as well in law before the tribunals of justice as a Christian, in any sense of the word, our free institutions are a failure. To sneer at free-thinkers of free thought is to make a thoughtless use of free speech, and to scoff at a privilege which we are bound to protect. The Constitution does not assume to create religious rights or to distribute them. It reverently recognizes and maintains them as original and universal, as rights which human government can neither grant nor withhold, which are not of human tenure, and which no man can give up. A single unresisted infringement, established as a precedent, subjugates the weak, and leaves them at the mercy of the strong. Every man and every parish is liable to hold unpopular theological opinions. And when the right to hold and inculcate such opinions is not sacred,

${ }^{256}$ CONG. Globe, 42D ConG., 2D SESS. 382-83 (1872); Calabresi \& Rickert, supra note 21, at 43.

${ }^{257}$ CONG. Globe, 40TH CONG., 2ND SeSS. APP. 469 (1868). 
and the violation of it is not sacrilege; when the constitutional defences of that right are dismantled, and it is left with no better security than the generosity and tolerance of an ecclesiastical court, or the caprice of a ruling class; when freemen are reduced to the consolation of remembering that the writ for burning heretics is obsolete, and of hoping that civilization will not suffer it to be revived,--the theory of our government is exploded and its original authority at an end. ${ }^{258}$

On a superficial level, it could be argued that there is no discrimination on the basis of religion today such that it could be said that we have a religious system of "caste." People can freely change religions - or choose not to practice any religion - without direct coercion by the government or private individuals. A person born into one religion is not stuck there for life. Even so, there are clearly some religions and religious sub-groups which have some caste like aspects to them.

For example, Judaism likely qualifies as a caste, although it is not a caste that faces a lot of open discrimination in the United States at the moment. According to Jewish law, a Jewish person is defined as someone who either was born to a Jewish mother or converted to Judaism. ${ }^{259}$ Once a person is considered Jewish according to Jewish law, he or she cannot become a nonJew. ${ }^{260}$ So, even if a Jew renounces his or her belief in Judaism or converts to another religion, he or she is still considered Jewish. Even such a person's children and grandchildren would be considered Jewish, as long as the matrimonial descent is maintained. Being Jewish is thus hereditary and immutable and has inherent elements of caste. Prejudice and discrimination against Jews as an inferior caste is far less common today in the United States than it was prior to the 1960's, but it persists in some places even today.

${ }^{258}$ Hale v. Everett, 53 N.H. 9, 275-276 (1868) (emphasis added).

259 See SHULChAN ARUCH EVEN HAEZER 8:5; BABYLONIAN TALMUd, KIDDUSHIN 66b, 68b.

${ }^{260}$ See RAMA, YOREH DE’AH 268:12; TALMUD BECHOROS 30B. 
The definition of a Jew is also well known in the non-Jewish world and has historically been used as a basis for persecuting Jews and treating them as an inferior caste. ${ }^{261}$ For instance, the Nazis did not define a person as Jewish based on his or her religious beliefs, but based on the person's inherited status as a Jew. ${ }^{262}$ Whether an individual defined himself or herself as a Jew or was a member of the Jewish community was irrelevant to the Nazi definition. ${ }^{263}$ Consequently, "[m]any Germans who had not practiced Judaism for years found themselves caught in the grip of the Nazi terror. Even people with Jewish grandparents who had converted to Christianity were defined as Jews."264 The Nazis clearly viewed a person's Jewish status as hereditary and immutable. Such entrenched persecution mirrors the immutability of the Indian caste system. It is also reminiscent of the disgraceful state laws in this country that defined individuals as "African-American" based on the "proportion of colored blood" in the individual's genealogy. ${ }^{265}$

Another religion where children effectively inherit their parents' religious status and beliefs is Islam. Children born to Islamic parents will usually be raised as Moslems and will be Moslems when they reach adulthood. Conversion from Islam to another religion is considered apostasy and is punishable by death, according to many Islamic scholars and regimes. ${ }^{266}$ Status as a Moslem is thus in essence inheritable and almost immutable just as is status as a Jew. Moslems inevitably are a kind of caste as are Jews.

\footnotetext{
${ }^{261}$ In 1872, Senator Sumner explicitly referenced Jews as an oppressed caste. See supra p.54.

262 The United States Holocaust Museum, http://www.ushmm.org/outreach/en/article.php?ModuleId=10007695 (last visited on December 20, 2011).

${ }^{263} \mathrm{Id}$.

${ }^{264} \mathrm{Id}$.

265 Plessy, 163 U.S. at 552 ("there is a difference of opinion in the different states; some holding that any visible admixture of black blood stamps the person as belonging to the colored race (State v. Chavers, 5 Jones [N. C.] 1); others, that it depends upon the preponderance of blood (Gray v. State, 4 Ohio, 354; Monroe v. Collins, 17 Ohio St. 665); and still others, that the predominance of white blood must only be in the proportion of three-fourths (People v. Dean, 14 Mich. 406; Jones v. Com., 80 Va. 544)").

${ }^{266}$ See Tuan N. Samahon, The Religion Clauses and Political Asylum: Religious Persecution Claims and the Religious Membership-Conversion Imposter Problem, 88 Geo. L.J. 2211 (2000).
} 
Children born to other religious parents may have caste-like attributes as well. Take, for instance, a child born into an Amish home. The child is born into a religious way of life without any choice in the matter. The child attends Amish schools and is taught Amish values and directed in Amish religious practices. Because of parental and social influences, the child likely has no opportunity or even ability to abandon the Amish religion until he or she is an adult. The child's religious status as an Amish practitioner is thus to some degree hereditary and immutable. Even a child born into a less rigid religious home will likely not change religions by virtue of the dominating influence of his or her parents.

Religious groups that fall within the definition of caste, such as Jews and Moslems, should certainly be protected from discrimination by the Fourteenth Amendment's no-caste principle. For this reason, we will argue below that a government program offering unequal educational opportunities for religious children relative to secular children violates the Fourteenth Amendment. ${ }^{267}$ Whether all religious individuals should receive the Fourteenth Amendment's protection from discrimination on the basis of caste simply because some religious individuals constitute a caste, is a more difficult question. But answering it is unnecessary because the Amendment's ban on all class legislation clearly protects all religious individuals including mainline Protestants, Catholics, members of the Eastern Orthodox Church, Mormons, and practitioners of Hinduism, Buddhism, and all other faiths.

\section{Religion as a Class}

As already discussed, a system of forbidden class legislation is one that singles out particular groups or individuals for special privileges or burdens quite apart from those borne by the rest of the members of society. Class legislation is by definition legislation which does not apply broadly to the general populace and which granted monopolies or other special privileges

\footnotetext{
${ }^{267}$ See discussion infra Part VI.A.
} 
to a favored group or imposed unique burdens on a particular disfavored group. The original understanding of the Fourteenth Amendment held that government could only make distinctions among classes of people if doing so was rational and necessary to serve a public purpose. Thus, in its 1897 ruling in Gulf, C. \& S.F. Ry. Co. v. Ellis, the U.S. Supreme Court reviewed the constitutionality of a law that awarded attorneys' fees to plaintiffs suing railroad companies but not to plaintiffs suing other corporations or individuals. ${ }^{268}$ The Supreme Court found that giving this benefit to plaintiffs suing railways but not to plaintiffs suing other corporations served no public purpose. So the Court struck down the law as unconstitutional class legislation. Under the principles enunciated in the Ellis case, classifications based on religion also serve no public purpose. They therefore violate the Fourteenth Amendment's ban on class legislation.

In fact, the Constitution's religion clauses served as among the first bans on some forms of class legislation discriminating against religion starting in 1787 and $1791 .^{269}$ The Free Exercise Clause and the No Religious Test Clause both essentially barred Congress from passing special or partial laws that place unique burdens on religion. And the Establishment Clause prevents Congress from passing a special or partial law that grants one religion a unique privilege or immunity that effectively disfavors all other religions. The Establishment Clause essentially blocks Congress from granting a monopoly on religion to one specific religion. As Professor McConnell has said:

the Establishment Clause of the First Amendment was designed to 'avoid undue concentrations of power' - specifically, to prevent the federal government (and, after the Fourteenth Amendment, all governments) from assuming the power to control the religious life of the American people ... Just as we want no governmental control of news media, telecommunications, or the arts, the First

\footnotetext{
${ }^{268} 165$ U.S. at 165-66.

${ }^{269}$ See Hamburger, supra note 124, at 336-340 Hamburger describes how states and the framers accepted that the legislature could not discriminate on the basis of religion and that individuals were entitled to the same privileges and rights as everyone else without regard to their religion. Hamburger quotes Madison that "in matters of religion no man's right is abridged by the institution of civil society, and that religion is wholly exempt from its cognizance."
} 
Amendment stands for the premise that religious decisions should be made by individuals, families, and voluntary associations, and not by the state.",270

The Religion Clauses of the original Constitution and of the federal Bill of Rights were thus consistent with the Lockean principle of allowing only general rules applicable to all religions only on similar terms. To be sure, the three Religion Clauses did not by themselves provide as sweeping protection against discrimination on the basis of religion as is mandate by the antidiscrimination command of the Fourteenth Amendment. ${ }^{271}$ But they were a good first start.

The Fourteenth Amendment dramatically expanded the limited ban on class legislation initially outlined in the 1787 and 1791 federal constitutional Religion Clauses. The Fourteenth Amendment broadly banned all class legislation across the board, whether based on religion or on any other improper classifications that gave some classes of citizens greater rights than were enjoyed by other classes of citizens. With regards to religion, the Amendment banned all forms of discrimination on the basis of religion, not just the few narrow forms specified in the Religion Clauses. There is no evidence in the legislative history that the Framers of the Fourteenth Amendment sought to carve religion out of the broad ban on class legislation that they meant to enact. And it is therefore unlikely that the ban on religious class legislation after 1868 should have simply regurgitated the minimal ban on class legislation set forth in the original Religion Clauses. The Framers knew how to narrow the scope of constitutional language when they wanted to do so, ${ }^{272}$ and there is not even a hint from the legislative history that the framers thought that religion should receive less protection than other groups. In contrast, the Framers

\footnotetext{
${ }^{270}$ Michael W. McConnell, Governments, Families, and Power: A Defense of Educational Choice, 31 Conn. L. Rev. 847, 848 (1999).

${ }^{271}$ See infra Part IV. (discussing the limited protection of the religion clauses).

${ }^{272}$ For instance, the Privileges or Immunities Clause only applies to "citizens of the United States," Section Two of the Fourteenth Amendment only guarantees males the right to vote; and the Fifteenth Amendment only outlaws abridging the right to vote based on "race, color, or previous condition of servitude."
} 
debated quite vigorously whether women should be protected from class legislation and what kind of protection from class legislation African Americans should receive. ${ }^{273}$

And if class legislation protects against discrimination on the basis of race, it surely bans discrimination on the basis of religion because multiple protections for religion in the text of the Constitution predate the Fourteenth Amendment indicating that from 1791 on religion was already a suspect class. The Free Exercise and Establishment Clauses protect religious liberty. And the No Religious Test Clause guarantees that individuals will not be barred from holding public office based on their religion. In contrast, in 1787 and in 1791 there were no such clauses indicating that race was a suspect class. Indeed African Americans were subjected to extraordinary oppression and were barred from holding public office and even from the rights of citizenship prior to ratification of the Fourteenth Amendment. It is extremely improbable that the Framers of the Fourteenth Amendment would have created a new, far-reaching protection from class legislation that applied only to racial classes which had been totally unprotected from discrimination prior to 1868 , yet deny protection to religious classes of people that actually had been recognized prior to 1868 as having suspect class status! The more rational approach would have been for the Framers of the Fourteenth Amendment to grant the new protection from class legislation to those groups which had been recognized as being suspect classes prior to 1868 and then decide which other groups like racial minorities or women should or should not also receive that same level of protection.

And in fact the Framers of the Fourteenth Amendment followed this logic precisely when considering whether women should receive protection from class legislation under the Fourteenth Amendment. The Framers chose to ban class legislation that discriminated on the

\footnotetext{
${ }^{273}$ See Calabresi \& Rickert, supra note 21, at 69 (citing backlash from feminists over the inclusion of the word "male in the Fourteenth Amendment).
} 
basis of race but not class legislation that discriminated on the basis of gender, even though women should have been protected under the Fourteenth Amendment's ban on caste systems and on class-based laws. ${ }^{274}$ The Framers refused to begin considering gender a suspect class by following a two-step process. First, they carefully considered and extensively debated whether women should be included in the Fourteenth Amendment's protection against hostile class legislation. ${ }^{275}$ This step was necessary because prior to 1868 women had few constitutional rights and had been subjected to extensive discrimination. The framers of the Fourteenth Amendment needed therefore to consider whether to include women in the Amendment's broad language or to create a carve-out excluding them from the Amendment's protection. They chose the latter route. Next, they explicitly excluded women from the protection of the text of the Fourteenth Amendment in Section Two which protects the voting rights of only "male citizens". ${ }^{276}$ Professor Calabresi and Ms. Rickert note that feminists did not object to the broad, unqualified language of Section One banning systems of class legislation, which they understood as including protection for women. ${ }^{277}$ It was only the discriminatory language of Section Two which used the word "male" that they objected to. ${ }^{278}$ In contrast to the extensive discussion about excluding women from the Amendment's protection against class legislation, there was absolutely no discussion of excluding religion from the Amendment's protection, and there was obviously no textual exclusion either. The Fourteenth Amendment's ban on class-based laws that discriminate against religion matches the ban the Amendment would have imposed against class-based laws that discriminate on the basis of sex had the word "male" not been deliberately inserted into Section

\footnotetext{
${ }^{274}$ See Calabresi \& Rickert, Supra note 21, at 66-70.

${ }^{275}$ See Id.

${ }^{276}$ See U.S. CONST. amend. XIV § 2 (ensuring that states shall not abridge the right to vote of "male inhabitants").

${ }^{277}$ Calabresi \& Rickert, supra note 21, at 49.

${ }^{278} I d$.
} 
Two. It is thus difficult to see how the Amendment's Framers could possibly have meant to exclude religion from the Amendment's ban on systems of class and caste.

And if the Fourteenth Amendment protects women from hostile class legislation, it surely protects religion from hostile class legislation as well. Professor Calabresi and Ms. Rickert have argued that the Fourteenth Amendment did not begin protecting women until 1919 when the Nineteenth Amendment was ratified. ${ }^{279}$ They point out that the Framers of the Fourteenth Amendment clearly excluded women from the anti-discrimination command of the Fourteenth Amendment by using the words "male inhabitants" in Section 2. But Calabresi and Rickert argue that when the Nineteenth Amendment granted women political rights including the right to vote, women automatically gained civil rights protection from hostile class legislation under the Fourteenth Amendment as well. Their reasoning is that granting a group of people political rights without granting that group civil rights is incoherent. They claim that the Fourteenth Amendment has an amoeba-like quality, automatically sucking up new groups with caste or class features to receive equal civil rights as those groups obtain equal political rights in future generations. It is hard to imagine that the Fourteenth Amendment would be able to automatically grant equal rights to groups, such as women, that never before enjoyed equality, even in 1868, yet exclude religious groups whose status as a suspect class dated all the way back to 1787 .

Finally, it should be highlighted that by 1868 , all state constitutions protected religion, usually in multiple ways, even though state constitutions at that time contained little protection against racial discrimination. Twenty-seven out of the thirty-seven states (73\%) had clauses in their state constitutions in 1868 when the Fourteenth Amendment was ratified that banned the establishment of religion. ${ }^{280}$ All thirty seven state constitutions in 1868 had Free Exercise Clause

\footnotetext{
${ }^{279}$ See Id. at 70-85; supra, at 70-72 (discussing further).
}

${ }^{280}$ Calabresi \& Agudo, supra note 37, 31-32. 
analogues. ${ }^{281}$ Twenty-four states $(65 \%)$ in 1868 had clauses prohibiting religious qualifications for holding public office. ${ }^{282}$ In contrast, only five states (14\%) in 1868 had clauses barring some form of discrimination on the basis of race. ${ }^{283}$ It is hard to imagine that these same states, with resounding protections of religion as a suspect class prior to 1868 and only minimal protection of race as a suspect class, would come together and ratify a Fourteenth Amendment that banned only class legislation on the basis of race but not class legislation on the basis of religion.

\section{The Fourteenth Amendment Automatically Protects Groups with Political Rights}

In America, a logical and fundamental theory of rights is that groups that have political rights, such as the right to vote and run for public office, are also guaranteed equal civil rights. ${ }^{284}$ This truism exists because political rights - the right to be counted in society and the ability to participate in the shaping of society - are uniquely valued in society. ${ }^{285}$ Some people, such as children or convicted felons, have civil rights but lack political rights. Other people, such as resident aliens, have some civil rights but not others and have no political rights. But groups of people that have political rights certainly have civil rights as well. ${ }^{286}$ To say otherwise would

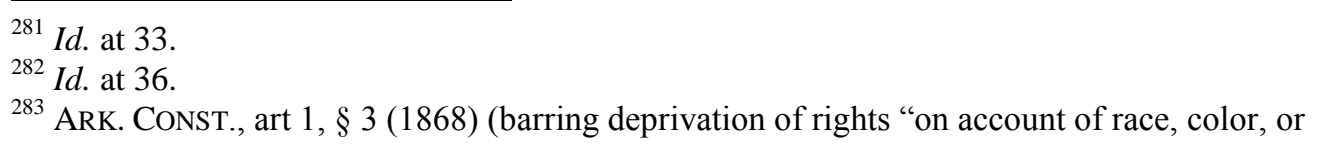

previous condition"); FLA. ConST., Art 17, § 28 (1868) ("There shall be no civil or political distinction in this State on account of race, color, or previous condition of servitude, and the legislature shall have no power to prohibit by law any class of persons, on account of race, color, or previous condition of servitude, to vote or hold any office, beyond the conditions prescribed by this constitution"); LA. ConsT., Title 1, Art 13 (1868) (guaranteeing "equal rights and privileges ... without distinction or discrimination on account of race or color"); S.C. CONST., art 1, § 39 (1868) (Distinction, on account of race or color, in any case whatever, shall be prohibited"); TEX. CONST., Art 1, Sec 21 (1868) ("nor shall any citizen ever be deprived of any right, privilege, or immunity, nor be exempted from any burden or duty, on account of race, color, or previous condition.")

${ }^{284}$ See Calabresi \& Rickert, supra note 21, at 69-76.

${ }^{285}$ See Calabresi, at 152; see also Calabresi \& Rickert, supra note 21, at 67-70.

${ }^{286}$ The view that political rights can be granted or held back might seem strange to the modern observer because political rights are sometimes viewed as fundamental rights. See Harper, 383 U.S. 663 (stating that "the right to vote is too precious, too fundamental to be so burdened or conditioned"). In Harper, the court dubiously held that a poll tax violated the Equal Protection Clause. $I d$. at 670. The majority explicitly rejected any need to adhere to the 
mean that the legislature could, for example, strip a group of people of the right to contract or the right to work outside the home, but that it could not eliminate that group's right to vote or hold public office. Such a construction is implausible. The history of women's rights is instructive.

In 1868, women did not have constitutionally protected political and civil rights. Although women should have qualified as a caste because of their immutable and hereditary physical features, women were not guaranteed equal civil rights or protected by the Fourteenth amendment from class based legislation because Section Two of the Fourteenth Amendment restricted voting rights protection to men only. ${ }^{287}$ It therefore became implausible to construe the anti-discrimination command of Section One of the Fourteenth Amendment as including women when Section Two of the Amendment explicitly excluded them from its protections. ${ }^{288}$ And indeed feminists were outraged when they learned that the word "male" would be included in Section Two because they understood the dire implications. ${ }^{289}$

But in 1919 when the Nineteenth Amendment granted women the right to vote, the Fourteenth Amendment's equality guarantee automatically expanded to protect women from class based laws. ${ }^{290}$ The reason for this is that granting a group of people the right to vote while simultaneously denying that group of people equal civil rights is simply irrational. ${ }^{291}$ The reason the Fifteenth Amendment was ratified to give African American men the right to vote just two

original meaning of the Constitution and instead relied on its perception of the evolving meaning of the Equal Protection Clause. Id. at 669 (stating that "the Equal Protection Clause is not shackled to the political theory of a particular era ... we have never been confined to historic notions of equality"). In so doing, the majority failed to cite any original sources for the fundamental right to vote. And it failed to explain why it was necessary to ratify the Fifteenth, Nineteenth, Twenty-Third, and Twenty-Fourth Amendments if the evolving meaning of the Equal Protection Clause otherwise engulfed the purpose of those provisions. Rather, Justice Black's dissent was likely more in line with the Constitution's original meaning. See Id. at 672-675 (Black, J., dissenting) (explaining that the Equal Protection Clause merely mandates rational basis review of voting restrictions, not strict scrutiny).

${ }^{287}$ See U.S. CONST. amend. XIV, §2 (amended 1920).

${ }^{288}$ See Calabresi \& Rickert, supra note 21, at 66-67.

${ }^{289} I d$., at 67.

${ }^{290}$ See Id. at 67-70.

${ }^{291}$ Id. at 67-68 
years after ratification of the Fourteenth Amendment is precisely because the Fourteenth Amendment only granted African-Americans equal civil rights, not equal political rights. ${ }^{292}$ And it is clear from the legislative history that the Framers understood that the Fourteenth Amendment was insufficient to guarantee African Americans the right to vote. ${ }^{293}$ It took the Reconstruction Framers only two years to realize that the Fourteenth Amendment's guarantee of equal civil rights for African Americans needed to be supplemented by the Fifteenth Amendment's guarantee of equal political rights to the same group. Thus, when fifty-two years after the enactment of the Fourteenth Amendment women got the right to vote, women suddenly had the same political rights as did white and African-American men. From 1920 on, it became implausible to argue that women had a constitutional right to vote for president, senator, and governor, but they could not be trusted to make a contract or own property without their husband's consent.

It should be underscored that granting political rights under the Fifteenth and Nineteenth Amendments does not render the Fourteenth Amendment superfluous. First, the Fourteenth Amendment banned all systems of caste and of class-based laws, thus creating a new level of civil rights protection previously not guaranteed by the Constitution. This broad-based civil rights protection extends to many groups beyond just classes defined by race, gender, and religion. For instance, Antebellum bans on class legislation mainly involved groups who were politically connected (or politically disfavored) or economic distinctions that were deemed unjustified or lacking in having a sufficient public purpose. ${ }^{294}$ And other groups, such as children, immigrants, or the disabled would also likely qualify for some protection from class based laws. Second, without the Fourteenth Amendment, legislatures could pass class legislation

\footnotetext{
${ }^{292}$ See Id. at 74-75 (discussing history of this issue).

${ }^{293} \mathrm{Id}$.

${ }^{294}$ See Saunders, supra note 19, at 251-264.
} 
or establish caste systems, such as European feudalism or the Indian caste system, even though they could not take away the right to vote based on gender or race. Prior to 1868 , the Constitution protected a variety of other civil rights, such as those enumerated in the Bill of Rights, but it did not outlaw systems of caste or class-base legislation explicitly as the Fourteenth Amendment did. Thus the Fourteenth Amendment ensures that critical civil rights not otherwise articulated in the Constitution or its Amendments get protected.

The political rights of religious individuals are explicitly protected in the Constitution. The No Religious Test Clause guarantees that individuals will not be barred from holding office based on their religion. ${ }^{295}$ The Clause makes no distinction as to whether the test discriminates against a particular religion or against all religions generally. The Clause thus rejects the argument commonly used by proponents of religious discrimination that discrimination on the basis of religion furthers an antiestablishment purpose. ${ }^{296}$ And in fact, religious individuals were the only group of people - the only suspect class in modern language -- to receive explicit protection of their political rights in the original Constitution of 1787.

The No Religious Test Clause not only bans laws imposing a religious test for holding office, but we think that it also implies that legislatures cannot restrict the ability to vote based on religion. It would be irrational to read the Constitution as prohibiting legislatures from barring individuals from holding public office based on their religion but as allowing legislatures to restrict voting rights based on religion. How could the Constitution possibly be read to trust someone to hold public office, including the office of President, but not trust that person with the right to vote? Under the Twenty-Sixth Amendment we allow citizens to vote starting from the

\footnotetext{
${ }^{295}$ U.S. CONST. art. VI, $\S 3$ ("no religious Test shall ever be required as a Qualification to any Office or public Trust under the United States").

${ }^{296}$ See Davey, 540 U.S. at 722 (explaining that refusing to fund private religious organizations while funding parallel private secular organizations served an important antiestablishment interest).
} 
age of eighteen, ${ }^{297}$ but we do not allow them to hold the greater trust of becoming a member of Congress until the age of twenty-five, ${ }^{298}$ a Senator until the age of thirty, ${ }^{299}$ or the President until the age of thirty-five. ${ }^{300}$ Suppose a law were passed that prevented people of all religions from voting, instead of just preventing members of a particular religion from voting? Such a law would still be invalid under the implication of the No Religious Test Clause because the Clause makes no distinction as to whether the discrimination it forbids targets a specific religious group or all religious individuals generally. So it seems that once the original Constitution in 1787 guaranteed religious individuals the right to hold federal public office, it also guaranteed them other political rights like the right to vote in federal elections. Since the Constitution specifies in Article I, Section 2 that voting eligibility must be the same for voting in U.S. House of Representatives elections as it is in voting for members of the most numerous branch of the state legislature, the states as well as the federal government are constitutionally barred from denying any citizen the right to vote on the basis of religion.

Because religious individuals thus have fully protected political rights against the federal and state governments - the right to hold public office, the right to vote, and the right to serve on juries - they automatically, like women since 1920, have fully protected equal civil rights that protect them from federal and state class-based legislation. Neither Congress nor the state legislatures can restrict the political rights of a single religion or of all religions as a whole. And Congress and the state legislatures therefore also cannot restrict the civil rights of a single religion or of all religions as a whole. To say otherwise would lead to the illogical result that religious individuals had a constitutionally protected right to vote and be elected president,

\footnotetext{
${ }^{297}$ See U.S. CONST. amend. XXVI.

${ }^{298}$ See U.S. CONST. art. I $\S 2$.

${ }^{299}$ See U.S. CONST. art. I $\$ 3$.

${ }^{300}$ See U.S. CONST. art. II $\S 1$.
} 
senator, or governor, but not to make contracts, buy property, or share a lunch counter with secular individuals. It would thus be utterly irrational to conclude that the anti-discrimination command of the Fourteenth Amendment does not ban discrimination on the basis of religion.

One possible counterargument is that because the individual political and civil rights of religious citizens are already protected by the very specific language of the Free Exercise and Establishment Clauses, one ought not to read the Fourteenth Amendment's general ban on discriminatory class-based legislation as superseding the very specific and on point language of the Religion Clauses. This argument is perhaps best illustrated by the Supreme Court's opinions affirming political rights for religious individuals under the Free Exercise Clause. ${ }^{301}$ In Torasco v. Watkins, for example, the Supreme Court held that a Maryland law requiring that a notary commissioner declare his or her belief in God violated the First Amendment (it was unclear whether the court was using the Free Exercise Clause or the Establishment Clause). ${ }^{302}$ The Supreme Court explained that the No Religious Test Clause was necessary prior to the adoption of the Bill of Rights for such claims of political rights, but that the First Amendment "broke new constitutional ground in the protection it sought to afford to freedom of religion." ${ }^{303}$ Indeed the Supreme Court does not appear to have ever used the No Religious Test Clause as the basis for a decision it has rendered. ${ }^{304}$ And under current Supreme Court case law, laws that restrict the right to vote or that restrict many but not all civil rights based on religion likely violate both the Establishment Clause ${ }^{305}$ and the Free Exercise Clause. ${ }^{306}$

\footnotetext{
${ }^{301}$ See, e.g., McDaniel, 435 U.S. 618 (striking down a Tennessee statute barring "ministers of the gospel, or priest[s] of any denomination whatever" from participating in the state's constitutional convention).

302367 U.S. at 492.

${ }^{303} \mathrm{Id}$.

${ }^{304}$ A search for "no religious test" in all Supreme Court cases turned up sixteen results, none of which used the clause to render a decision

${ }^{305}$ See infra Part IV.B. (explaining the Establishment Clause tests in Lemon v. Kurtzman, 403 U.S. 602, 612-13 (1971) and Agostini v. Felton, 521 U.S. 203, 234 (1997)), as well as the Free Exercise Clause; see also Colorado Christian Univ. v. Weaver, 534 F.3d 1245, 1257-1259 (10th Cir. 2008) (holding that a law banning funding to only
} 
But the Supreme Court's case law on the Free Exercise, Establishment, and No Religious Test Clauses is largely inconsistent with the original meaning of these clauses, and there is state conduct, such as the adoption of Blaine amendments, that under current case law does not violate the Religion Clauses but which should be read as violating the Fourteenth Amendment's antidiscrimination principle. The Free Exercise and Establishment Clauses combat only certain specific types of governmental actions that hurt religious citizens but that do not implicate political rights. ${ }^{307}$ These two clauses create protections uniquely required for religion. In contrast, the No Religious Test Clause guarantees religious individuals' political rights. The Torasco court's declaration that the No Religious Test Clause is superfluous following ratification of the First Amendment is indefensible as an original matter or under any plausible theory of textual interpretation.

To see why the Fourteenth Amendment's anti-discrimination command adds and should add concrete protections for religion above and beyond those afforded by the Religion Clauses, it is necessary to briefly canvass the protection of religion from hostile class legislation since 1787.

\section{History of Religious Equality in America}

The protection of religious liberty from hostile class legislation has a very long history in this country predating the ratification of the Fourteenth Amendment by centuries. ${ }^{308}$ Several of the original thirteen North American colonies were purposely established to be safe havens for

\footnotetext{
"pervasively sectarian" schools violated the original meaning of the Establishment Clause because the Establishment Clause demanded "equal treatment of all religious faiths without discrimination or preference"); see also Douglas Laycock, "Nonpreferential" Aid to Religion: A False Claim About Original Intent, 27 Wm \& Mary L.Rev. 875, 922-23 (1986) (explaining that the Establishment Clause prohibited both discrimination against specific religious groups and discrimination against all religious groups in general).

${ }^{306}$ See infra Part IV.A. (discussing Sherbert v. Verner, 374 U.S. 398 (1963) and Thomas v. Review Board of the Indiana Employment Security Division, 450 U.S. 707 (1981)). Such a law also might violate the due process clause because of enforceability problems, such as determining who was sufficiently religious to have his or her right to vote restricted.

${ }^{307}$ See infra Part IV.

${ }^{308}$ See generally Hamburger, supra note 124, at 295-367 (discussing history of religion and equal protection in the Eighteenth century).
} 
religious minorities and some of those colonies through their laws ensured religious toleration, albeit imperfect in our modern eyes. ${ }^{309}$ And it is generally recognized that the core purpose of the Free Exercise and Establishment Clauses of the First Amendment was the protection of religion from certain kinds of hostile class legislation and the furtherance of religious liberty. ${ }^{310}$ The equal protection of religion can be seen in state constitutions, in pre-1868 court cases, in the political history of the Fourteenth Amendment, and in the legislative history of the Fourteenth Amendment. This diverse and widespread historical evidence shows an overwhelming sensitivity to the need to protect religion from hostile class legislation. As Thomas Cooley wrote, "the general voice has been, that persons of every religious persuasion should be made equal before the law, and that questions of religious belief and religious worship should be questions between each individual man and his Maker." ${ }^{311}$ It is therefore inconceivable that the framers of the Fourteenth Amendment meant to incorporate a ban on class-based laws that discriminated on the basis of race but not against class-based laws that discriminated on the basis of religion. Religion had by 1868 been a suspect class since colonial times. Surely, if racial classifications are to

\footnotetext{
${ }^{309}$ See Michael W. McConnell, The Origins and Historical Understanding of Free Exercise of Religion, 103 Harv. L. Rev. 1409, 1424-1430 (1990) (noting the religious toleration in Maryland, Rhode Island, Pennsylvania, Delaware, and Carolina and discussing the development of religious protection in the colonies).

${ }^{310}$ See, e.g., Kurland, supra note 18, at 17-18 (arguing that the religion clauses must be "read together as creating a doctrine more akin to the reading of the equal protection clause than to the due process clause, i.e., they must be read to mean that religion may not be used as a basis for classification for purposes of governmental action ...."); Schempp, 374 U.S. at 305 (Goldberg, J., concurring) (the "single end" of the religion clauses is "to promote and assure the fullest possible scope of religious liberty and tolerance for all and to nurture the conditions which secure the best hope of attainment of that end"); Jesse H. Choper, The Religion Clauses of the First Amendment: Reconciling the Conflict, 41 U. Pitt. L. Rev. 673, 678 (1980) (arguing that the "central aim of the Religion Clauses [is] protection of religious liberty"); Michael W. McConnell, Accommodation of Religion, 1985 Sup. Ct. Rev. 1 ("religious liberty is the central value and animating purpose of the Religion Clauses"); Steven H. Shiffrin, The Pluralistic Foundations of the Religion Clauses, 90 Cornell L. Rev. 9 (2004); Lawrence G. Sager, The Free Exercise of Culture: Some Doubts and Distinctions, in Engaging Cultural Differences: The Multicultural Challenge in Liberal Democracies 165, 165-75 (Richard A. Schweder et al. eds., 2002); Christopher L. Eisgruber \& Lawrence G. Sager, The Vulnerability of Conscience: The Constitutional Basis for Protecting Religious Conduct, 61 U. Chi. L. Rev. 1245, 1282-83 (1994); Meyler, supra note 17.

311 CONSTITUTIONAL LiMitATIONS, supra note 100, at 960.
} 
receive strict scrutiny under the Fourteenth Amendment and to be upheld only in the face of a compelling public purpose, the same must be true of laws that classify on the basis of religion.

\section{Historical persecution of religion and the founders' response}

The Framers of the Constitution and Bill of rights were well aware of the ugly history of religious persecution in England when they wrote those documents. ${ }^{312}$ For instance, church elections were famously manipulated by the King. King Henry II thus allowed the church to hold "free" elections but ordered it to elect his clerk; ${ }^{313}$ and King Henry VIII assumed full personal control of the church and claimed the power to appoint church officials. ${ }^{314}$ Prior to the rise of King Charles I, the Church of England dominated the landscape in Elizabethan and Stuart England, and the supporters of the Church of England thoroughly suppressed religious dissenters such as Protestants and Roman Catholics. ${ }^{315}$ By the 1630's, high Church Anglicans allied with Charles I and his Catholic Queen causing Protestant dissenters to flee England for the safety of living in the Massachusetts Bay and Connecticut colonies. This exodus for the new world continued in the 1640's during the waging of the English Civil War between Oliver Cromwell and the dissenting Protestants and Charles I and his high church Anglicans. Following the English Civil War, Protestants executed King Charles I and his Archbishop of Canterbury and similarly persecuted dissenters from Puritanism. Cromwell and his allies confiscated property, denied free religious exercise, and imprisoned non-Protestants. ${ }^{316}$ Following the return of the monarchy in 1660, the persecution of Protestant dissenters resumed and the persecution of

\footnotetext{
${ }^{312}$ See generally McConnell, supra note 309, at 1421-1474; see also Hosanna-Tabor, 132 S. Ct. at 702-704 (recounting the history of religious persecution in England and how it impacted the framers when they wrote the First Amendment); Murdock v Pennsylvania, 319 U.S. 105, 115-17 (1943) (commenting that the First Amendment was designed to protect religious individuals from persecution by banning such practices as "taxes on knowledge"). ${ }^{313}$ See W. WARREN, HENRY II 312 (1973).

${ }^{314}$ See G. Elton, THE TUdOR CONSTITUTION: DOCUMENTS AND COMMENTARY 331-332 (1960).

${ }^{315}$ See McConnell, supra note 309, at 1421.

${ }^{316}$ See Id.
} 
Catholics continued ${ }^{317}$ The Test Act of 1672 denied public and military office to non-Anglicans and required that everyone follow the religious practices of the Church of England. ${ }^{318}$

Eager to escape the religious persecution of England, many dissenters fled to America, but unfortunately they brought some bad English habits with them. The Puritans in the Massachusetts Bay colony, for example, persecuted dissenters, even executing some Quakers. ${ }^{319}$ In Virginia, Puritans and Catholics were expelled because the Church of England was the established church there, and Baptists were horsewhipped. ${ }^{320}$ The Massachusetts Constitution of 1780 eventually guaranteed equal treatment of religions but only for Christians, ${ }^{321}$ and Massachusetts proved to be unfriendly to Presbyterians, Baptists, and Quakers. ${ }^{322}$ Many other states also had religious test oaths requiring public officials to declare their adherence to a particular religion. ${ }^{323}$ By 1787, eleven states prohibited non-Christians from holding public office, and four prohibited non-Protestants from holding office. ${ }^{324}$

Jews also suffered tremendous persecution in England historically, ${ }^{325}$ as they did throughout Europe. ${ }^{326}$ In the Twelfth and Thirteenth Centuries, Jews were subjected to mob violence in England perpetrated by both the royal crown and private individuals. ${ }^{327}$ Blood libels

${ }^{317}$ See Id. at 1421-1422.

${ }^{318}$ See Id.

${ }^{319}$ Id. at 1423 .

${ }^{320}$ Id.

${ }^{321}$ MASS. CONST., Part 1, art. 3 (1780) (“And every denomination of Christians, demeaning themselves peaceably, and as good subjects of the commonwealth, shall be equally under the protection of the law: and no subordination of any one sect or denomination to another shall ever be established by law").

${ }^{322}$ McConnell, supra note 309, at 1423.

${ }^{323}$ See J. Suzanne Bell Chambers, Applying the Break: Religion and the Peremptory Challenge, 70 Ind L J 569,597

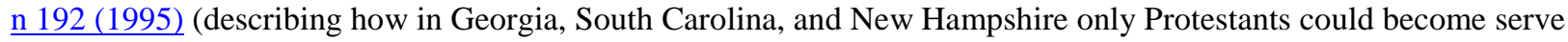
in the legislature but how other states, such as Vermont and Pennsylvania had less severe restrictions).

${ }^{324}$ McConnell, supra note 309, at 1474.

${ }^{325}$ See generally Jewish Virtual Library, The Virtual Jewish History Tour - England, available at www.jewishvirtuallibrary.org/jsource/vjw/England.html\#Contacts (last visited April 3, 2012) [hereinafter "Jewish Virtual Library].

${ }^{326}$ See Jewish Virtual Library, The Virtual Jewish History Tour, http://www.jewishvirtuallibrary.org/jsource/vjw/ (describing anti-Semitism in many other European countries)

${ }^{327} \mathrm{Id}$. 
persisted, and there were many incidents of mobs murdering Jews and stealing Jewish property. ${ }^{328}$ During this time, Jews were singled out for many special legal disadvantages, including higher taxes, prohibitions on owning land, bans on inheritance from parent to child, and substantial restrictions on trade and occupation. ${ }^{329}$ Finally, in 1290, King Edward I formally expelled all the Jews from England a full 202 years before the Spanish Inquisition expelled the Jews from Spain. It was not until the 1650's, under Oliver Cromwell, that the Jews were again allowed back into the England, and Jews in England continued to have limited legal rights and religious freedom from the 1650 's until the mid-Nineteenth Century. ${ }^{330}$

It was against this backdrop of bloody religious warfare and intolerance that the Framers of the U.S. Constitution and Bill of Rights sought to guarantee religious liberty. By enacting the Establishment Clause, in the very first clause in the Bill of Rights, the Framers ensured that there would never be a national church. As James Madison said, the Establishment Clause responded to the concern that "one sect might obtain a pre-eminence, or two combine together, and establish a religion to which they would compel others to conform." ${ }^{331}$ By enacting the Free Exercise Clause in the Bill of Rights, the Framers barred the government from discriminatorily targeting religious worship. And regarding the No Religious Test Clause, Oliver Ellsworth of Connecticut, later Chief Justice of the United States, wrote:

[T] he sole purpose and effect of [the ban on religious tests for office] is to exclude persecution, and to secure to you the important right of religious liberty .... In our country every man has a right to worship God in that way which is most agreeable to his own conscience. If he be a good and peaceable citizen, he is liable to no penalties or incapacities on account of his religious sentiments; or in other words, he is not subject to persecution. ${ }^{332}$

\footnotetext{
${ }^{328} I d$.

${ }^{329} \mathrm{Id}$.

${ }^{330} \mathrm{Id}$.

${ }^{331}$ See 1 ANNALS OF CONG. 730-731 (1789) (remarks of J. Madison).

${ }^{332}$ See Ellsworth, A Landholder VII, in 14 THE DOCUMENTARY HISTORY OF THE RATIFICATION OF THE Constitution 448, 449 (J. Kaminski \& G. Saladino eds. 1983) (originally published in the Connecticut Courant, Dec. 17, 1787); McConnell, supra note 309, at 1474.
} 
The Religion Clauses thus worked in concert to guarantee religious liberty and guard against the religious persecution which had pervaded England and the colonies. ${ }^{333}$ For this reason, Thomas Jefferson described both the Establishment Clause and the Free Exercise Clause as "building a wall of separation between Church \& State." 334

Prior to the adoption of the Bill of Rights, several states proposed amendments to the original Constitution of 1787 which give us a sense of the passion the Framers had for protecting religious freedom. For instance, New York proposed, "That the people have an equal, natural, and unalienable right freely and peaceably to exercise their religion, according to the dictates of conscience .... .335 New Hampshire proposed, “Congress shall make no laws touching religion, or to infringe the rights of conscience." ${ }^{336}$ And James Madison proposed, "The civil rights of none shall be abridged on account of religious belief or worship, nor shall any national religion be established, nor shall the full and equal rights of conscience be in any manner, or on any pretext, infringed." ${ }^{337}$ These proposed amendments demonstrate how extraordinarily significant religious liberty was to the founders. Though the final version of the Free Exercise Clause that was ultimately ratified did not guarantee the level of equality mandated by the Fourteenth Amendment, the notion that religious individuals should not be equal before the law would have been considered odious to the Framers of the original Constitution.

\section{State constitutions and court cases prior to 1868}

\footnotetext{
${ }^{333}$ See Hosanna-Tabor, 132 S. Ct. at 703.

33416 JEFFERSON'S WORKS 281 (Monticello ed.1903).

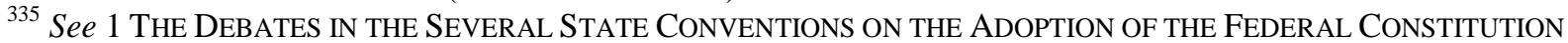
327 (J. Elliot 2d ed. 1836) (July 26, 1788) (emphasis added); See McConnell, supra note 309, at 1480-1481 (noting that Virginia, North Carolina, and Rhode Island made similar proposals);

336 See 1 ELLIOT'S DEBATES 326 (June 21, 1788) (emphasis added).

337 See 1 AnNALS OF Cong. 451 (J. Gales ed. 1834) (Aug. 15, 1789), 796 (Aug. 20, 1789) (proposal of James Madison, June 8, 1789) (emphasis added).
} 
Many early state constitutions guaranteed equality of religion in ways that mirrored the bans we discussed earlier on special and partial laws. ${ }^{338}$ For instance, Vermont's 1786 territorial constitution, which was one of the first constitutions to contain a broad equality guarantee in American history, ${ }^{339}$ stated,

...it is our indispensable duty to establish such original principles of government as will best promote the general happiness of the people of this State, and their posterity, and provide for future improvements, without partiality for, or prejudice against, any particular class, sect, or denomination of men whatever. ${ }^{340}$

The language "sect, or denomination" referred to religion and reflected the view that religion was a suspect classification and discrimination on the basis of religion was the quintessential form of improper discrimination with which the Framers were concerned at that time. Some state constitutions guaranteed that an individual's civil rights would not be burdened or privileged on account of his religion. A typical provision read, "The civil rights, privileges, or capacities of any citizen, shall in no way be diminished, or enlarged, on account of his religious principles." 341

\footnotetext{
${ }^{338}$ Meyler, supra note 17, at 293-311.

${ }^{339}$ See Calabresi, Agudo, \& Dore, supra note 145, at 96 (listing Massachusetts and Pennsylvania as the other two states to initially contain equality guarantees).

${ }^{340}$ VT. CONST. of 1786, Preamble. Delaware's constitution also had a provision that involved banning religious discrimination, but it did so somewhat awkwardly and even discriminatorily in retrospect. See DE Decl. of Rights, Section 3 ("That all persons professing the Christian religion ought forever to enjoy equal rights and privileges in this state, unless, under colour of religion, any man disturb the peace, the happiness or safety of society.")

${ }^{341}$ ALA. CONST. of 1819, DECL. OF RIGHTS, § 6; see also N.J. CONST. of 1776, art. XIX ("[N]o Protestant inhabitant of this Colony shall be denied the enjoyment of any civil right, merely on account of his religious principles, [and all members of Protestant sects] shall fully and freely enjoy every privilege and immunity, enjoyed by others their fellow-subjects."); PA. CONST. of 1776, pmbl. ("Government ought to be instituted ... for the security and protection of the community as such, and to enable the individuals who compose it to enjoy their natural rights ... without partiality for, or prejudice against any particular class, sect, or denomination of men."); PA. CONST. of 1776, DECL. OF RIGHTS, art. II ("Nor can any man, who acknowledges the being of a God, be justly deprived or abridged of any civil right as a citizen, on account of his religious sentiments or peculiar mode of religious worship.") (emphasis added); S.C. CONST. of 1778, art. XXXVIII ("[A]11 denominations of Christian Protestants in this State, demeaning themselves peaceably and faithfully, shall enjoy equal religious and civil privileges.") (emphasis added); VT. CONST. of 1786, ch. I, art. III ("[N]or can any man be justly deprived or abridged of any civil right as a citizen on account of his religious sentiments or peculiar mode of religious worship."); VA. CONST. of 1830, art. III, § 11 ("No man shall be ... enforced, restrained, molested or burdened, in his body or goods, or otherwise suffer on account of his religious opinions or belief; but all men shall be free to profess, and by argument to maintain, their opinions in matters of religion, and the same shall in no wise affect, diminish, or enlarge their civil capacities.")
} 
Some state constitutions even created a positive legislative duty to protect religion and possibly foster free exercise. For instance, the Texas Constitution said, "It shall be the duty of the legislature to pass such laws as may be necessary to protect every religious denomination in the peaceable enjoyment of their own mode of public worship." ${ }^{342}$ Some guaranteed an individual's right to exercise his religion without the influence of governmental burdens or privileges. For instance, the Maryland Constitution provided,

"That, as it is the duty of every man to worship God in such manner as he thinks most acceptable to him; all persons, professing the Christian religion, are equally entitled to protection in their religious liberty; wherefore no person ought by any law to be molested in his person or estate on account of his religious persuasion or profession, or for his religious practice." 343

These provisions provided religious practitioners with significantly enhanced protection from class legislation than did the Free Exercise Clause and Establishment Clause of the federal Constitution. And they reflect a commitment to religious equality.

A few states even explicitly endorsed religious equality. The Massachusetts Constitution, though establishing Christianity as the state religion, explicitly endorsed equality for the different branches of Christianity: "every denomination of Christians, demeaning themselves peaceably, and as good subjects of the commonwealth, shall be equally under the protection of the law: and no subordination of any one sect or denomination to another shall ever be established by law." ${ }^{344}$ Similarly, Maryland's clause read, "all persons are equally entitled to protection in their religious

\footnotetext{
${ }^{342}$ TeX. CONST. of 1868, art. I, § 4. See Calabresi \& Agudo, supra note 37, at 40 (noting that Nebraska and Ohio had similar provisions)

${ }^{343}$ MD. CONST. OF 1776, DECL. of RIGHTS, art. XXXIII (emphasis added); see also ALA. CONST. of 1819, Decl. of Rights, $\S 7$ ("' $\mathrm{N}] \mathrm{o}$ preference shall ever be given by law to any religious sect, society, denomination, or mode of worship ...."); CAL. CONST. of 1849, art. I, \&4 ("The free exercise and enjoyment of religious profession and worship, without discrimination or preference, shall forever be allowed in this State ....").

${ }^{344}$ MASS., part 1, art. 3 (1780) (emphasis added).
} 
liberty; wherefore, no person ought, by any law to be molested in his person or estate, on account of his religious persuasion or profession, or for his religious practice."345

By 1868 when the Fourteenth Amendment was ratified, many states had outright bans against class legislation imbedded in their religion clauses. Professor Calabresi and Sarah Agudo have pointed out that twenty-seven out of the thirty-seven states $(73 \%)$ had clauses in their state constitutions that banned the establishment of religion. ${ }^{346}$ But most of these clauses did much more than merely prevent the legislature from passing a law "respecting an establishment of religion," as the federal Constitution mandates. ${ }^{347}$ Instead they actually banned religious class legislation. A typical clause read, "No preference shall be given by law to any Christian sect or mode of worship." ${ }^{348}$ Giving a preference to a religious group is a special law, comparable to the giving of an economic preference to a class of merchants. A related but distinct formulation of state establishment clauses read, "No person shall by law be compelled to join or support, nor be classed with, or associated to, any congregation, church, or religious association." ${ }^{349}$ Compelling individuals to join or support a certain religion effectively grants a monopoly to that religion because it eliminates the ability of "consumers of religion" to select their preferred religion. The supply of religion is restricted to a single religion, demand for religion is affixed by the government, and the competitive market for religion is terminated. In sum, twenty-two states $(59 \%)$ in 1868 , a majority, had this stronger language in their establishment clauses when the Fourteenth Amendment was ratified. These clauses clearly indicate that a majority of the states

\footnotetext{
${ }^{345}$ See, e.g., MD., DECL. OF RIGHTS art. 36 (1867) (emphasis added); see also ME CONST. of 1819, art. 1, § 3 (“and all persons demeaning themselves peaceably as good members of the State shall be equall under the protection of the laws, and no subordination nor preference of any one sect or denomination to another shall ever be established by law, nor shall any religious test be required as a qualification for any office or trust, under this State ... ")

${ }^{346}$ Calabresi \& Agudo, supra note 37, at 31-32.

${ }^{347}$ U.S. CONST. amend. I.

${ }^{348}$ CONN. CONST. of 1819 , art. $1, \S 4$.

${ }^{349} I d$., art. $7, \S 1$.
} 
in 1868 recognized the problem of religious class legislation and sought to eradicate it more fully than would be accomplished simply by approving a replica of the federal establishment clause.

Some early court cases also emphasized the equal protection of religion in their opinions. ${ }^{350}$ In the 1799 case of Runkel $v$. Winemiller, Judge Chase granted a writ of mandamus to a minister in a dispute with his congregation, relying on the principle that "the pastors, teachers and ministers, of every denomination of [C]hristians, are equally entitled to the protection of the law, and to the enjoyment of their religious and temporal rights." ${ }^{351}$ In this context, equal protection meant that contractual obligations and rights applied equally to all members and leaders of a church without any special privilege or burden. ${ }^{352}$ In the 1876 decision in Ferriter v. Tyler, the Vermont Supreme Court declared that the Vermont Constitution was

... designed ... to secure to every subject equal civil rights, irrespective of his religious faith; so that his being a Catholic or a Protestant- - his being a Calvinist or an Arminian - his being an orthodox evangelical or a free-thinker- his being a Baptist or a Universalist - an Episcopalian or a Quaker, should not make him the object of discriminating legislation or judicial judgment to his disadvantage, as compared with those of different faith and practice, - so that no law should be aimed or executed against him because he professed and practiced one form of religious belief or disbelief rather than another, within the limits of personal immunity consistent with good order and the peace of society under the government. ${ }^{353}$

\section{Religion and Abolition}

\footnotetext{
${ }^{350}$ In Town of Pawlet v. Clark, 13 U.S. 292 (1815), a case involving a dispute over glebe rights, the defendant's attorney stated in the course of his argument that "by the first principles of our government it is contemplated that all religious sects and denominations of Christians, whose religious tenets are consistent with allegiance to the constitution and government of this state, should receive equal protection and patronage from the civil power."

3514 H. \& McH. 429, 450 (1799).

352 Id. at $450-451$.

${ }^{353} 48 \mathrm{Vt}$. 444, 465 (1876) (holding that a school did not have to grant a religious exemption and could expel a child for missing school to attend church on a religious holiday).
} 
Religion played an important role in the abolition of slavery. ${ }^{354}$ The first American and British abolitionists were deeply religious individuals who recognized the moral depravity of slavery. ${ }^{355}$ Quakers, Methodists, and Presbyterians were some of the early abolitionists. ${ }^{356}$

Religious abolitionists viewed slavery as "irreconcilable with the manifested will of our Great Creator, and with the imperative declaration of our blessed Savior 'all things whatsoever ye would that men should do to you, do ye even so to them; for this is the law and the prophets.",357 As Joseph Story put it, slavery was illegal because it was "repugnant to the great principles of Christian duty, the dictates of natural religion, the obligations of good faith and morality, and the eternal maxims of social justice." ${ }^{358}$ Religious abolitionists believed that it was their religious duty to end slavery, and they embarked on a large-scale political campaign in New England and in Congress itself where groups of clergymen and other religious individuals sought to end

\footnotetext{
${ }^{354}$ See generally Kurt T. Lash, The Second Adoption of the Free Exercise Clause: Religious Exemptions Under the Fourteenth Amendment, 88 Nw. U. L. Rev. 1106, 1131-1137 (1994); See also CHARLES RAPPEYE, SONS OF PRovidence: The Brown Bothers, the Slave Trade, AND the AMERICAN ReVolution (2006).

${ }^{355}$ See THOMAS SOWELL, BLACK REDNECKS AND White LIBERALS 116 (2005). (“[T]he principal impetus for the abolition of slavery came first from very conservative religious activists - people who would today be called 'the religious right."')

${ }^{356}$ See Bradley S. Tupi, Religious Freedom and the First Amendment, 45 Duq. L. Rev. 195, 246 (2007) (citing W. O. Blake, THE History of SLAVERY AND the SlaVe Trade 169-72 (1858)).

${ }^{357}$ Address to the Citizens of the State of Ohio, Concerning What Are Called The Black Laws (Issued in Behalf of the Society of Friends of Indiana Yearly Meeting, 1848) reprinted in SLAVERY, RACE, AND THE AMERICAN LEGAL SySTEM, 1700-1872, SER. No. 7, 2 STATUTES ON SLAVERY: THE PAMPHLET LitERATURE 101, 101 (Paul Finkelman ed., 1988)).

${ }^{358}$ United States v. La Jeune Eugenie, 26 F. Cas. 832, 846 (C.C.D. Mass. 1822) (No. 15,551). Benjamin Rush also said, "Slavery is repugnant to the principles of Christianity. It is rebellion against the authority of a common Father. It is a practical denial of the [effect] of the death of a common Savior. It is [encroaching on the authority] of the great Sovereign of the universe who has solemnly claimed an exclusive property in the souls of men." See Tupi, supra note 356, at 246-247 (citing MinUTES OF THE PROCEEDINGS OF A CONVENTION OF DELEGATES FROM THE ABOLITION SOCIETIES 24 (1794)).
} 
slavery under the law. ${ }^{359}$ Other abolitionists took a more radical view: "By what rule is [assisting runaway slaves] justifiable? By the commands of the bible, and the whole spirit of the gospel."360

White slave owners often restricted African American slaves' religious practices to prevent religiously-inspired rebellions. Southern slave owners and governments became concerned that religion was leading to abolition and to slave rebellion. Notably, Charles Finney, a preacher in New York, led a popular religious revival in 1824-1825 based on a liberal theology that emphasized social work. ${ }^{361}$ Many of Finney's followers significantly furthered the abolitionist cause and became prominent abolitionists in the mid-Nineteenth century. ${ }^{362}$ Nat Turner and Denmark Vesey were also preachers who led significant rebellions against white slave owners. ${ }^{363}$ Nat Turner's bloody rebellion led to the death of seventy whites and caused many whites to fear that religion was a potential threat to their system of slavery. ${ }^{364}$ Denmark Vesey invoked the Bible to inspire rebellion. As one slave testified, "At this meeting Vesey said ... that we ought to rise up and fight against the whites for our liberties .... [H]e read to us from the Bible, how the Children of Israel were delivered out of Egypt from bondage." 365

As a result, southerners established harsh laws restricting slaves' ability to exercise their religion, including draconian regulations on black religious assemblies. ${ }^{366}$ For instance, in the District of Columbia, "all meetings for religious worship, beyond the hour of ten o'clock at night,

\footnotetext{
${ }^{359}$ See Lash, supra note 354, at 1132-1133 (describing their abolition campaigns).

${ }^{360}$ Id. at 1132 n.119 (citing REV. W. BEARDSLEY, NARRATIVE AND FACTS, RESPECTING AlANSON WORK, JAS. E. Burr AND GEO. ThOMPSON, PRISONERS IN THE MisSOURI PENITENTIARY, FOR THE ALlEGED CRIME OF NEGRO STEALING (1842)).

${ }^{361}$ See Lash, supra note 354, at 1131 n.114.

${ }^{362} \mathrm{Id}$.

${ }^{363}$ See Jane Rutherford, Equality As the Primary Constitutional Value: The Case for Applying Employment Discrimination Laws to Religion, 81 Cornell L. Rev. 1049, 1051 (1996).

${ }^{364}$ Lash, supra note 354, at 1133.

365 See Rutherford, supra note 363 , at 1052 n.9.

${ }^{366}$ See Lash, supra note 354, at 1134-1135, n.133 (detailing some of the oppressive laws in different states).
} 
of free negroes, mulattoes or slaves, shall be and they are hereby declared to be unlawful." 367

And in South Carolina, it was illegal for "assemblies of slaves, free negroes, mulattoes and mestizoes" to meet "in a confined or secret place."368 Law enforcement personnel could administer "corporal punishment, not exceeding twenty lashes, upon such slaves, free negroes, \&c., as they may judge necessary for deterring them from the like unlawful assemblage in the future. ${ }^{, 369}$ Many laws prohibited slaves from preaching or religious practice unless in the presence of whites. ${ }^{370}$ Under this tight regulation, religious gatherings invariably espoused proslavery ideology and encouraged slaves to obey their masters. ${ }^{371}$ There were also laws prohibiting blacks from reading the Bible, ${ }^{372}$ becoming ministers, ${ }^{373}$ preaching, ${ }^{374}$ and leaving their plantations on "Sundays, fast days, and holy days.",375

This religious oppression repulsed many observers and drove many to support abolition. ${ }^{376}$ As Charles Sumner wrote,

"Is it not strange that the Church, or any body of men, upon whom the faintest ray of Christianity has fallen, should endeavor to exclude the African, 'guilty of a skin not coloured as their own,' from the freest participation in the privileges of

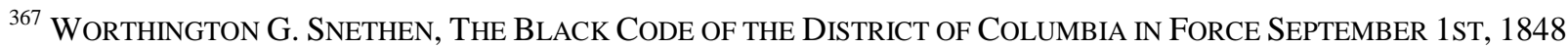
(A. \& F. Antislavery Society, 1848), reprinted in 2 STATUTES ON SLAVERY: THE PAMPHLET LITERATURE 179,224 (reprinting and quoting Ordinances of the Corporation of Washington (Oct. 29, 1836)).

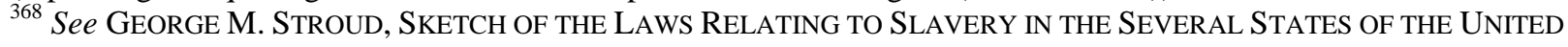
StATES OF AMERICA (1827), reprinted in 1 StATUTES ON SLAVERY: THE PAMPHLET LiterATURE 157, 245 (Paul Finkelman ed., 1988) (citing 2 Brevard's Digest).

${ }^{369} I d$.

${ }^{370}$ See, e.g., Act of 1805, ch. XII, 1805 VA. ACTS (barring slaves from going to religious ceremonies except those conducted by whites); Act of December 1831, ch. 94, 1845 MD. LAWs (prohibiting all religious meetings for blacks unless conducted by whites); Act of 1847, s 2, 1847 Mo. LAWs at 104 (preventing blacks from preaching unless a police officer was present to "prevent all seditious speeches").

${ }^{371}$ See Lash, supra note 354 , at 1134-1135.

${ }^{372} I d$. at 1136.

${ }^{373}$ See, e.g., Act of 1832 , ch. IV, 1832 N.C. SESS. LAWS 7.

${ }^{374}$ See, e.g., Act of 1847, s 2, 1847 Mo. LAWs 103, 104 ("no meeting or assemblage of negroes ... for the purpose of religious worship, or preaching, shall be held or permitted when the services are performed or conducted by negroes $\ldots$ unless some sheriff, constable, marshall, police officer, or justice of the peace, shall be present").

${ }^{375}$ Rutherford, Supra note 363, at 1051.

${ }^{376}$ See Lash, supra note 354, at 1136-1137.
} 
worshipping the common God?-It would seem as if prejudice, irrational, as it is uncharitable, could no further go."377

Former slave and prominent abolitionist Henry Highland Garnet declared in a speech, "Nearly three millions of your fellow citizens, are prohibited by law ... from reading the Book of Life.»378 Charles Gardner also observed, "access to that heavenly chart, which is laid down by Jehovah as the only safe rule of faith and practice, the liberty of reading and understanding how he may serve G-d acceptably." ${ }^{379}$ He further said, "See then, the wickedness of those laws which go contrary to the law of God, and say to the slave, 'You shall not read these Scriptures, nor understand them, nor teach them to your children, nor obey them.' Is it not morally right, and politically safe, to abolish such a system?"380

\section{Recognizing the need to protect religion}

The legislative history of the Fourteenth Amendment shows that the Framers of that Amendment recognized the oppression of slaves' religious practices and existing discrimination on the basis of religion and sought to rectify it. ${ }^{381}$ James Wilson, Chair of the House Judiciary Committee and sponsor of the Civil Rights Act of 1866, noted slavery's “incessant, unrelenting, aggressive warfare upon ... the purity of religion." ${ }^{382}$ Lyman Trumbull, the cosponsor of the Civil Rights Act of 1866, also highlighted the religious oppression of blacks, specifically noting laws preventing them from "exercising the function of a minister" and making it "a highly penal offense for any person ... to teach slaves." ${ }^{383}$ Congressman James Ashley said that "slavery has

\footnotetext{
${ }^{377}$ Letter from Charles Sumner to John Jay (May 25, 1843), in 1 THE SELECTED LETTERS OF CHARLES SUMNER 129, 129-30 (Beverly W. Palmer ed., 1990).

${ }^{378}$ Speech by Henry Highland Garnet, delivered before the National Convention of Colored Citizens, Buffalo, New York (Aug. 16, 1843), in 3 The Black AbOlitionist PAPERs 403, 406 (C. Peter Ripley ed., 1991).

${ }^{379}$ Speech by Charles W. Gardner, delivered at the Broadway Tabernacle, New York, New York (May 9, 1837), in 3 THE BLACK ABOLITIONIST PAPERS, supra note 369, at 206.

${ }^{380}$ Id. at 211.

${ }^{381}$ See generally Lash, supra note 354, at 1146-1149.

382 CONG. GlOBE, 38TH CONG., 1ST SESS. 1199 (1864); Lash, supra note 354, at 1146.

${ }^{383}$ CONG. GlOBE, 39TH CONG., 1ST SESS. 474 (1865); Lash, supra note 354, at 1146.
} 
silenced every free pulpit within its control." 384 And Senator Henry Wilson said, "religion . . . never has been and never will be allowed free exercise in any community where slavery dwarfs the consciences of men." ${ }^{385}$ Wilson also remarked, "[ $[\mathrm{t}]$ he bitter cruel relentless persecutions of the Methodists in the South, almost as void of pity as those which were visited upon the Huguenots in France, tell how utterly slavery disregards the right to free exercise of religion." ${ }^{386}$ Senator George Edmunds of Vermont later commented that the Constitution bans discrimination based on classifications that are "sectarian," 387 which was a code word for Catholic in the Nineteenth Century and reflected bigotry towards non-Protestant denominations. ${ }^{388}$

In 1866, President Andrew Johnson recognized the history of religious persecution and pointed out how the American Constitution protects religious liberty: "The ancient republics absorbed the individual in the State, prescribed his religion, and controlled his activity. The American system rests on the assertion of the equal right of every man to life, liberty, and the pursuit of happiness; to freedom of conscience, to the culture and exercise of all his faculties."389 Representative Banks similarly condemned the way in which establishments of religion had historically been used as a means of oppression:

... in a State which has an established religion, any citizen might be compelled to conform to its doctrines, and to leave his descendants to the same mental and moral servitude, deprived of the freedom of belief, and without that freedom of worship to which, according to the laws of nature and of God, every man is entitled. Society is necessary to the existence of man, and government

\footnotetext{
${ }^{384}$ CONG. GlOBE, 38Th CONG., 1ST SESS. (1864); Lash, supra note 354, at 1146.

385 Cong. Globe, 38Th CONG., 1st SESS. (1864); Lash, supra note 354, at 1146.

${ }^{386}$ CONG. GLOBE, 38Th CONG., 1ST SESS. 1202 (1864); Lash, supra note 354, at 1147.

3873 CONG. REC. 1870 (1875) (stating that the Fourteenth Amendment "protected a right of her citizens against class prejudice, against caste prejudice, against sectarian prejudice.”); Calabresi \& Rickert, supra note 21, at 41 n.188.

${ }^{388}$ Helms, 530 U.S. at 828-29; see also Douglas Laycock, Comment, Theology Scholarships, the Pledge of Allegiance, and Religious Liberty: Avoiding the Extremes but Missing the Liberty, 118 Harv. L. Rev. 155, 188-89 (2004); Steven K. Green, The Blaine Amendment Reconsidered, 36 Am. J. Legal Hist. 38 (1992) [hereinafter "Blaine Amendment Reconsidered"].

${ }^{389}$ CONG. GlOBE 1, 39Th CONG., 1St SESS. (1866) (Statement of the President).
} 
indispensable to his civilization, prosperity, and power. But the perpetual subjection of every person born within its jurisdiction, without consent and in disregard of protest or removal, is not necessary in any form of political society. It does not rest upon any theory of justice, and the whole course of civilization disproves its justice or wisdom. ${ }^{390}$

Banks went on to praise American democracy for furthering religious liberty.

The Framers of the Fourteenth Amendment also recognized the free exercise of religion as one of the Privileges or Immunities protected by that Amendment and as being a fundamental right. ${ }^{391}$ In 1871, John Bingham, the author of the Privileges or Immunities Clause, stated that the free exercise of religion was within the "scope and meaning" of Section One of the Fourteenth Amendment. ${ }^{392}$ Henry L. Dawes similarly remarked that the Privileges or Immunities Clause had "secured the free exercise of ... religious belief." ${ }^{, 393}$ In listing the rights secured by the Privileges or Immunities Clause, Senator Jacob Howard mentioned "the personal rights guaranteed and secured by the first eight amendments to the Constitution."394 John Sherman said that the "right to worship God according to the dictates of one's own conscience is not only a right, but a privilege which in a Christian country a man ought to enjoy."395 Congressman Maynard commented that "privileges and immunities" includes the "personal right" of "freedom ... in religion. ${ }^{396}$ Representative John Stockton mentioned the First Amendment Religion Clauses as an example of how the Fourteenth Amendment "prohibits the states from doing what the Congress was always prohibited from doing." ${ }^{397}$ These statements are unsurprising since it

\footnotetext{
${ }^{390}$ Cong. Globe 96, 40Th Cong., 2ND SESS. (1868) (Report to Committee on Foreign Affairs by Representative Banks).

${ }^{391}$ See Lash, supra note 354, at 1146-1149. Scholars also discuss how the Fourteenth Amendment incorporated the Free Exercise Clause. See Michael K. Curtis, No State Shall Abridge (1986); Akhil R. Amar, The Bill of Rights as a Constitution, 100 Yale L.J. 1131 (1991).

${ }^{392}$ CONG. GlOBE, 42D CONG., 1ST SeSS. 84 app. (1871).

${ }^{393}$ CONG. GlOBE, 42D CONG., 1ST SESS. 475 (1871).

${ }^{394}$ Cong. Globe, 39TH Cong., 2ST SeSS. 2765 (1865).

395 CONG. GlOBE, 42D ConG., 2D SESS. (1872).

${ }^{396}$ CONG. GlOBE, 42D CONG., 1ST SESS. (1871).

${ }^{397}$ Cong. Globe, 42D CONG., 1St SeSS. (1871).
} 
was recognized that one of the privileges and immunities violated by slavery was the free exercise of religion. ${ }^{398}$

And the legislative history also reflects that the framers recognized the religious oppression in other countries and connected it to caste and class-based systems of law and the problems of discrimination in this country. Senator Charles Sumner condemned the religious caste system in India and the persecution of the Jews in Europe prior to the French Revolution, implying that there was a need to protect against contemporary religious discrimination. ${ }^{399}$ Representative Charles Van Wyck said, "The meanness of caste in this country on account of color is no more wicked than the caste of nation, religion, or blood in Great Britain." ${ }^{, 400}$ Senator Garrett Davis also compared the oppression of blacks to the oppression of Jews and Gypsies in other countries: "the negro slaves, as separate and distinct and insoluble almost as Jew and Gypsy." ${ }^{401}$ Following ratification, Representative William Purman recognized that the Fourteenth Amendment banned class legislation directed at religion, asking rhetorically, "Shall hostile legislation in States be permitted to oppress any class of citizens on account of religion, nativity, politics, or complexion, or deny to any such class their inalienable rights, among which are life, liberty, and the pursuit of happiness, and thus defeat the very spirit and provision of the Constitution itself?" ${ }^{402}$ In discussing the ramifications of the Fourteenth Amendment, Representative Samuel McKee said, "if any gentleman, chooses to associate with a colored man,

\footnotetext{
398 See, e.g., CONG. GlOBE, 38TH CONG., 1ST SESS. 1202 (1864) (Henry Wilson expressing this view).

${ }^{399}$ See supra at p54 (citing ConG. GlOBE, 42D CONG., 2D SESS. 382-83 (1872)).

400 CONG. Globe, 40Th CONG., 2ND SESS., app. 469 (1868).

${ }^{401}$ Cong. Globe, 39Th Cong., 1St SESs. 249 (1866) (Statement of Mr. Davis); see also Cong. GlOBE, 36TH CONG., 1ST SESS., 453 (1860) (statement of Mr. Clingman) ("Why northern as well as southern men, and even Canadians, characterize them as the most worthless of the human race. Formerly the Abolitionist ascribed their degradation to the want of political and social privileges. But during the middle ages, in Europe, the Jews were not only without political privileges, but were, as a class, odious and severely persecuted, yet they were, nevertheless, intelligent, energetic, and wealthy. In point of fact, in some portions of the northern states, the negro has been made a pet of, and but for his native inferiority, must have thriven and even become distinguished.")

4022 CoNG. REC. 423 (1874) (Statement of Mr. Purman).
} 
with a black man or any other man or race of men, even the Hindoo or the Hottentot, he can do

it. I believe in every man having the same show in this world for life, and when he develops all the capacities that fit men for the highest rights, of citizenship, then let him have them." ${ }^{403}$

Court opinions also explicitly recognized that the Fourteenth Amendment banned religious class legislation. In Pollock v. Farmers' Loan \& Trust Co. , the Supreme Court said,

Whenever a distinction is made in the burdens a law imposes or in the benefits it confers on any citizens by reason of their birth, or wealth, or religion, it is class legislation, and leads inevitably to oppression and abuses, and to general unrest and disturbance in society. It was hoped and believed that the great amendments to the Constitution which followed the late civil war had rendered such legislation impossible for all future time. But the objectionable legislation reappears in the act under consideration. It is the same in essential character as that of the English income statute of 1691, which taxed Protestants at a certain rate, Catholics, as a class, at double the rate of Protestants, and Jews at another and separate rate. ${ }^{404}$

Riding circuit in 1879, Ho Ah Kow v. Nunan, Justice Field struck down a law permitting prison guards to shave the queues of prisoners because the law was directed at the religious practices of Chinese immigrants and therefore violated the Fourteenth Amendment's ban on class legislation on the basis of religion. ${ }^{405}$ Justice Field wrote that "hostile and discriminating legislation by a state against persons of any class, sect, creed or nation, in whatever form it may be expressed, is forbidden by the fourteenth amendment of the constitution. ${ }^{, 406}$ Similarly, in Am. Sugar-Ref. Co.

v. State of Louisiana, Justice Brown stated,

Of course, if such discrimination were purely arbitrary, oppressive, or capricious, and made to depend upon differences of color, race, nativity, religious opinions, political affiliations, or other considerations having no possible connection with

\footnotetext{
${ }^{403}$ Cong. Globe, 39Th Cong., 1St Sess. 452 (1866) (Statement of Mr. McKee)

${ }^{404} 157$ U.S. 429, 596 (1895) (emphasis added).

40512 F. Cas. 252 (C.C.D. Cal. 1879).

${ }^{406} I d$. at 256.
} 
the duties of citizens as taxpayers, such exemption would be pure favoritism, and a denial of the equal protection of the laws to the less favored classes. ${ }^{407}$

The Wisconsin Supreme Court also recognized that religious groups "certainly have the same right to equal protection of the laws as secular organizations."

This history shows that protecting religion was very much on the minds of the Framers of the Fourteenth Amendment. It is hard to imagine that the Framers would have limited the scope of the Fourteenth Amendment to rectifying the existing problem of discrimination on the basis of race without rectifying the existing problem of discrimination on the basis of religion. Arguably, the framers felt that by granting African-Americans rights under the Thirteenth and Fourteenth Amendments, African-Americans would automatically receive all other constitutional protection, including free exercise. ${ }^{409}$ But if that were true, then it would have been sufficient to simply guarantee African Americans the same constitutional rights as all other citizens. Instead the Fourteenth Amendment guaranteed to all citizens equality in their privileges or immunities of federal and of state citizenship. Thus was born a whole new constitutional right - the right not to be discriminated against in class legislation. It is extremely unlikely that the Framers of the Fourteenth Amendment would observe and condemn religious oppression directed at AfricanAmericans and yet take no action to guarantee religious freedom for everyone in the future especially at a time when the Framers were taking action to prevent racial discrimination in the

\footnotetext{
${ }^{407} 179$ U.S. 89, 92 (1900); see also Connolly v. Union Sewer Pipe Co., 184 U.S. 540, 568-69 (1902) (same); Alaska Fish Salting \& By-Products Co. v. Smith, 1793-A, 1919 WL 214 (D. Alaska June 7, 1919) aff'd sub nom. 255 U.S. 44 (1921) (same).

${ }^{408}$ In re Garrabad, 84 Wis. 585, 54 N.W. 1104, 1106 (1893); see also Fountain Park Co. v. Hensler, 155 N.E. 465, 468 (Ind. 1927) (holding that a statute granting the power of eminent domain to a religious group constituted improper class legislation).

${ }^{409}$ This assumption was evidently untrue with regards to political rights because two years later the framers had to reconvene to ratify the Fifteenth Amendment granting blacks political rights. But it might have been true with regards to other civil rights, such as religious practice.
} 
future. It is considerably more plausible that the Framers observed the problems of both religious and racial oppression and ratified a two-in-one solution to wipe them both out. ${ }^{410}$

\section{Foreign Constitutions and Laws Guaranteeing Equality}

At least forty-five foreign constitutions ban discrimination on the basis of religion, just as they ban discrimination based on other impermissible classifications, such as race and gender. ${ }^{411}$ Although foreign constitutions are generally not helpful for establishing the original meaning of the Fourteenth Amendment, ${ }^{412}$ they do indicate that, as a general rule, when constitutional framers get together to guarantee equality, they protect religion from discrimination too. These foreign constitutional provisions show that banning discrimination on the basis of religion is a core principle of western constitutional democracy. Judges that are concerned with keeping American constitutional law in line with generally accepted western democratic principles surely would recognize that discrimination on the basis of religion, like discrimination on the basis of race and gender, is intolerable.

The evidence here is overwhelming and is cited in an appendix to this article because it is too lengthy to include here in text or footnotes. ${ }^{413}$ The list shows that the vast majority of western constitutional democracies countries have constitutionally guaranteed equality for religion, and even some non-democratic countries ban discrimination on the basis of religion too. Almost

\footnotetext{
${ }^{410}$ A significant counterargument is that evidence of the framers' intent to exclude religion from the Fourteenth Amendment is demonstrated by the history of Blaine Amendments, which openly discriminate against religion in the funding private organizations. We address this issue in the section on Blaine Amendments, infra Part V.

${ }^{411}$ This list is by no means exhaustive but gives us a fairly accurate snapshot of modern worldview on religious discrimination. See Appendix for text of these provisions. In the Appendix, we also include provisions from Israel's Declaration of Independence, the Soviet Union's constitution, and the Hawaiian constitution, although we did not count any of these provisions towards the list of forty-five. Also, Belgium's constitution probably guarantees religious equality. Its equality provision states, "There are no class distinctions in the State." art. 10. And the Beligium Constitution guarantees equal funding for religious schools. art. 24. But because it does not specifically ban religious discrimination, we excluded it from the list.

${ }^{412}$ See generally The Relevance of Foreign Legal Materials in U.S. Constitutional Cases: A Conversation Between Justice Antonin Scalia and Justice Stephen Breyer, 3 Int'1 J. Const. L. 519 (2005) (Justice Scalia's explanations of why foreign law is not relevant for determining the original meaning of the U.S. Constitution).

${ }^{413}$ See Appendix.
} 
every European constitution guarantees equality for religion, and every continent has at least one country with an equality guarantee prohibiting discrimination on the basis of religion. Large diverse countries, such as India, ${ }^{414}$ Germany, ${ }^{415}$ and Russia, ${ }^{416}$ have these provisions; and smaller, more homogenous countries, such as Iceland, ${ }^{417}$ Ireland, ${ }^{418}$ and Estonia ${ }^{419}$ have them too. Older constitutions, such as the Dutch ${ }^{420}$ and Canadian ${ }^{421}$ ones, have these guarantees; and newer constitutions such as the ones from Chechnya ${ }^{422}$ and Bosnia and Herzegovina ${ }^{423}$ also have them. The general trend amongst countries worldwide is to include equality guarantees for religion in constitutions. A typical provision - the Canadian Equal Protection Guarantee -- reads, "Every individual is equal before and under the law and has the right to the equal protection and benefit of the law, without discrimination and, in particular, without discrimination based on race, national or ethnic origin, colour, religion, sex, age or mental or physical disability." ${ }^{424}$ International conventions have similarly protected religion. The European Convention for the Protection of Human Rights and Fundamental Freedoms states, "The enjoyment of the rights and freedoms set forth in [the] Convention shall be secured without discrimination on any ground such as sex, race, colour, language, religion, political or other opinion, national or social origin, association with a national minority, property, birth or other status. ${ }^{, 425}$ The Universal Declaration of Human Rights reads, "Everyone is entitled to all the rights and freedoms set forth

\footnotetext{
${ }^{414}$ INDIA CONST. art. 15, 16, 29, 30, 325.

415 GRUNDGESETZ FÜR DIE BUNDESREPUBLIK DEUTSCHLAND art. 3 (Ger.).

${ }^{416}$ KonstitutSIIA RosSISKOI FEDERATSII art. 14, 19 (Russ.).

${ }^{417}$ ICE. CONST. art. 64, 65.

${ }^{418}$ IR. CONST. art. 40, 44.

${ }^{419}$ EST. CONST. art. 12.

${ }^{420}$ NETH. CONST. ch. 1 art. 1.

${ }^{421}$ CAN. CONST. ARTICLE 15 (emphasis added).

422 CHECHNYA CONST. art. 16.

${ }^{423}$ BOSN. \& HERZ. CONST. art. I par. 7, art. II, par. 4.

${ }^{424}$ CAN. CONST. Art. 15 (emphasis added).

${ }^{425}$ Nov. 4, 1950, art. 6(1), 213 U.N.T.S. 221 (emphasis added),
} 
in this Declaration, without distinction of any kind, such as race, colour, sex, language, religion, political or other opinion, national or social origin, property, birth or other status." ${ }^{426}$

The Civil Rights Act of 1964 also provides extensive protection against discrimination on the basis of religion for individuals in the workplace, as it does for discrimination on the basis of race and gender. For instance, the Act states,

It shall be an unlawful employment practice for an employer (1) to fail or refuse to hire or to discharge any individual, or otherwise to discriminate against any individual with respect to his compensation, terms, conditions, or privileges of employment, because of such individual's race, color, religion, sex, or national origin ... 427

We should add that under the Civil Rights Act of 1964 not only is discrimination on the basis of race and gender barred, but also the existence of a racially hostile or sexually hostile work environment is barred as well. Companies thus cannot hire in a non-discriminatory way but allow for the existence of a hostile work environment. The same thing must of course be true as to the ban on religion discrimination under the 1964 Civil Rights Act. Just as no private employer can legally refuse to hire or promote someone on the basis of religion, no employer can maintain a workplace that is hostile to religion or that discriminates on account of religion either. If a religious group seeks to use office space for religious reasons or if employees want to wear religious symbols, the Civil Rights Act of 1964 should be read as giving them that right.

Taken together, these foreign and international human rights clauses barring discrimination on the basis of religion indicate that when people get together to ban discrimination and guarantee equality, they include religion alongside race and gender. The same thing happened in the United States with the Civil Rights Act of 1964. For some reason,

\footnotetext{
${ }^{426}$ G.A. Res. 217A (III), U.N. Doc. A/810, art. 2 (1948) (emphasis added).
}

${ }^{427} 42$ U.S.C. $\$ 2000 \mathrm{E}-2$ (emphasis added). 
however, the U.S. Supreme Court has never caught on to this global and American trend for banning discrimination on account of religion.

\section{Class Legislation and Modern Case Law}

\section{A. Class Legislation Doctrine}

In assessing whether a particular statute constituted class legislation, Nineteenth Century courts applied a two-step test. First, courts asked whether a law created a unique burden or privilege either against or in favor of a defined class of people. If the answer to this first question was "yes" then the court would ask whether the law furthered a public purpose and is a just law enacted for the good of the whole people in which case it would be constitutionally permissible. In other words, under the Nineteenth Century test for disallowing class legislation laws can discriminate as long as they "are designed, not to impose unequal or unnecessary restrictions upon any one, but to promote, with as little individual inconvenience as possible, the general good." 428 The Nineteenth Century two-step test could probably be described as a rational basis test with a legitimate public purpose requirement.

Under the current rational basis test, a law simply needs to have a rationale, no matter how dubious the goal or whether the stated rationale is actually the one that the legislature relied on in passing the law. In Williamson v. Lee Optical Co., the Supreme Court upheld the constitutionality of a law forbidding "any person not a licensed optometrist or ophthalmologist to fit lenses to a face or to duplicate or replace into frames lenses or other optical appliances.”429 Practically, this meant that "no optician can fit old glasses into new frames or supply a lens,

\footnotetext{
${ }^{428}$ Barbier, 113 U.S. at 31-32.

429 348 U.S. 483,485 (1955).
} 
whether it be a new lens or one to duplicate a lost or broken lens, without a prescription." ${ }^{430}$ The Court held that the law had a rational basis and was therefore constitutional. ${ }^{431}$

But under a class legislation analysis of the kind we defend here, the law in Williamson $v$. Lee Optical should have been struck down. The law created a special privilege for optometrists and ophthalmologists, artificially boosting demand for their services when unlicensed individuals could have performed the same work perfectly well and safely. There was absolutely no public purpose being served by the law since it did not have a public welfare objective, such as the promotion of the public health or safety. And the law probably even hurt consumers by artificially driving up costs and nonsensically adding red tape. Instead, the law was merely special interest legislation designed to generate business for optometrists and ophthalmologists. To be sure, the threshold for overcoming the public purpose requirement is not and should not be very high absent the making of a suspect classification - the government need only show that the law in question serves a rational public purpose. But a naked desire to help or hurt one group of people or industry over another is not by itself proof of a public purpose. The Lee Optical court's error was its failure to take seriously its responsibility to assess the validity of the purpose, which the law in question pursued.

The Nineteenth Century two-step test for invalidating class legislation does not apply in the same way to all Fourteenth Amendment cases. In cases involving fundamental rights, such as those enumerated and protected in the Bill of Rights, or with respect to suspect classifications which are presumptively irrational, such as classifications on the basis of race, sex, or religion, the Nineteenth Century two-step test leads to a strict scrutiny analysis. No law discriminating on the basis of race, sex, or religion should be upheld unless it survives strict scrutiny and serves a

\footnotetext{
${ }^{430} I d$. at 486 .

${ }^{431} I d$. at 491 .
} 
compelling and general governmental interest. This approach is sensible as a practical matter because most laws discriminate, and are nonetheless constitutional in part because the mere requirement that laws serve a "public purpose" or provide "general welfare benefit" is in practice a pretty flabby level of protection. The government could probably justify many if not most kinds of discriminatory laws under a public purpose rationale. And leaving core constitutional rights and protections or the making of suspect classifications without a thicker guardrail would leave vital constitutional guarantees open to significant trampling. So, layering a strict scrutiny requirement on top of the Nineteenth Century two-step test is perfectly sensible and consistent with the Fourteenth Amendment's equality guarantee and with the post United States v. Carolene Products and incorporation case law. ${ }^{432}$

The Supreme Court's 1942 opinion in Skinner v. Oklahoma is instructive. There, the court received a Fourteenth Amendment challenge to an Oklahoma law requiring sterilization of prisoners convicted of two or more "felonies involving moral turpitude." ${ }^{433}$ By its own terms, the Oklahoma law included convictions for larceny as being felonies that involved moral turpitude but it exempted convictions for high class felonies involving "revenue acts, embezzlement, or political offenses." ${ }^{434}$ The old common law distinctions between larceny and embezzlement were highly technical and overall not very meaningful. For instance, if a person entered a chicken coop and stole chickens, he would commit an act of larceny and could be sterilized; but if he were instead the bailee of the chickens and misappropriated them, then that action would constitute embezzlement, and he could escape sterilization. ${ }^{435}$ The law was based on the now-

\footnotetext{
432304 U.S. 144 (1938).

433 Skinner, 316 U.S. at 536-537.

${ }^{434}$ Id.

${ }^{435}$ See Id., 316 U.S. at 538-539 (detailing some examples).
} 
debunked "science" that society could eliminate crime by sterilizing repeat-offenders thereby preventing those criminals from disseminating their criminally-inclined genes. ${ }^{436}$

Among the enthusiastic defenders of the "science" of eugenics were Justice Oliver Wendell Holmes and the new leader of Nazi Germany, Adolph Hitler. Holmes had famously opened the door to eugenic sterilization in Buck v. Bell, a case which upheld as constitutional -in spite of a class legislation Equal Protection claim -- a compulsory state sterilization law of the unfit, including the mentally retarded. ${ }^{437}$ Justice Holmes concluded his opinion with the words: “Three generations of imbeciles are enough.” Justice Pierce Butler, later a foe of the New Deal, was the lone dissenter, and he filed no opinion.

Professor Victoria Nourse has detailed how, when Skinner v. Oklahoma was decided in 1942, everyone still understood the Fourteenth Amendment as a ban on class legislation, and some scholars and lawyers viewed sterilization laws as a classic example of the evils of class legislation at work. ${ }^{438}$ Previous sterilization cases, such as Buck v. Bell, were decided in part on class legislation grounds, ${ }^{439}$ and the lawyers in Skinner made their arguments in that case explicitly in class legislation terms. ${ }^{440}$ Skinner was ultimately decided as a class legislation case and is relevant for seeing how strict scrutiny and class legislation analyses intersect.

The Oklahoma law that was challenged in Skinner raised several class legislation problems. First, larceny and embezzlement were basically the same kind of offense. They were both forms of thievery distinguished only by a technicality which bore no relevance to the severity of the criminal action. Arbitrary, coin-flip quality distinctions constitute class legislation

\footnotetext{
${ }^{436}$ See generally VICTORIA F. NOURSE, In RECKLESS HANDS: SKINNER V. OKLAHOMA AND THE NEAR TRIUMPH OF EUGENICS (2008).

437 274 U.S. 200 (1927).

${ }^{438} I d$. at 28-29, 166-168 (describing the class legislation approach at the time).

${ }^{439}$ Id. at 185 n.35 (citing other sterilization cases).

${ }^{440} \mathrm{Id}$. at 67-68, 141, 149.
} 
and this law made such an arbitrary coin-flip distinction. It was as irrational and class-based as a law allowing titles of nobility or any other form of hereditary favoritism. Second, a deeper look at the distinction between larceny and embezzlement reveals that larceny included "low class" crimes, such as stealing chickens, while embezzlement included "high class" crimes, such as misappropriation of funds. Thus, under the Oklahoma law in Skinner, a lowly chicken thief got sterilized while a white collar financier, convicted of bank fraud, was exempt from sterilization. The law thus created an aristocracy of crime, violating Locke's maxim that there should be "one law for rich and poor, for the favorite at court and the countryman at plough." ${ }^{441}$ Third, some of the prisoners held in the prison out of which the Skinner case arose wondered why they were the only ones being sterilized when many other people, such as the mentally impaired, were not subject to compulsory sterilization even though they probably carried defective or degenerate genes as well. ${ }^{442}$ And fourth, some critics of the eugenics movement worried in 1942 that eugenics laws would open the door to sterilizing other disfavored groups. ${ }^{433}$ Presumably, the prevailing majority in the legislature could use sterilization to eradicate dissenters or to target racial minorities. In fact, Adolph Hitler's Germany was engaged in precisely such an effort, in 1942, at the very time that Skinner was decided.

The Skinner court initially subjected the Oklahoma law to the Nineteenth Century class legislation two-step test under the Fourteenth Amendment. First, the Court recognized that the law discriminated against people convicted of larceny relative to people convicted of embezzlement. ${ }^{444}$ And second, the Court deferred to the legislature's public policy goals showing

\footnotetext{
${ }^{441} I d$. at 141, 167-168.

${ }^{442} I d$. at 67-68.

${ }^{443} I d$. at $28-29$

${ }^{444}$ See Skinner, 316 U.S. at 538-539.
} 
typical New Deal Supreme Court deference to the legislature, however arbitrary the law in question might seem. ${ }^{445}$ Just as predicted, the public purpose qualification proved quite flabby.

But the Court did not end its Fourteenth Amendment analysis there. It went on to make three crucial observations, which served as the basis for subjecting the law to strict scrutiny. First, the Court commented that the law "involves one of the basic civil rights of man. Marriage and procreation are fundamental to the very existence and survival of the race."446 Second, the Court remarked, "The power to sterilize, if exercised, may have subtle, farreaching [sic] and devastating effects. In evil or reckless hands it can cause races or types which are inimical to the dominant group to wither and disappear." ${ }^{447}$ And third, the Court noted, "There is no redemption for the individual whom the law touches. Any experiment[,] which the State conducts is to his irreparable injury. He is forever deprived of a basic liberty." ${ }^{448}$ Based on these observations, the Court applied strict scrutiny and found the law's arbitrary line-drawing untenable when balanced against the fundamental right exercised and the substantial damage caused. ${ }^{449}$

Skinner v. Oklahoma thus stands as a Nineteenth Century class legislation case where a fundamental liberty - the right to procreate - was being denied to low class thieves but not to high class thieves. This was something that not even the deferential New Deal Supreme Court could ignore. The law in question discriminated among different classes of thieves, but it did not do so to promote the general interest but did so instead to promote the interests of high class thieves. Thankfully, the justices put a stop to this law and with their decision they helped to stop the eugenics movement that Justice Holmes had done so much to promote in Buck v. Bell.

\footnotetext{
${ }^{445}$ Id. at $539-540$.

${ }^{446} I d$. at 541 .

${ }^{447}$ Id.

${ }^{448}$ Id.

${ }^{449}$ Id. at 541-542.
} 
Justice Field spelled out another important qualification to the Nineteenth Century public purpose requirement in Barbier v. Connolly. There, the Supreme Court upheld a San Francisco city ordinance subjecting laundries in certain parts of San Francisco to allegedly special and "burdensome" restrictions because the public concerns could "be remedied only by the state."450 The ordinance was defended on the ground that it promoted the public health and safety. Such arguments of public health and safety are usually a trump card for the government in the post Lochner v. New York era. ${ }^{451}$ Courts will usually uphold laws challenged on class legislation grounds at least in situations where a law is addressing a public health and safety problem that is of such an extraordinary magnitude that it can only be remedied by the state.

Skinner and Barbier therefore bring out important qualifications to the Nineteenth Century two-step test for unconstitutional class legislation. Skinner shows that even if a discriminatory law has a public purpose, it can still be subjected to strict scrutiny if it 1) infringes in a discriminatory way as to a fundamental right like the right to procreate, 2) if the law in question has far-reaching consequences and is subject to political abuse, or 3) if the means used by the law are unreasonably damaging and disproportionate. Barbier, in contrast, shows that the Supreme Court will usually defer to the political branches as to the significance of the public health and safety problem that the government claims it is addressing.

The original meaning of the Fourteenth Amendment's ban on class legislation is therefore fairly easily harmonized with the modern Supreme Court's use of strict scrutiny when classifications are made on such suspect grounds as race, sex, or religion. In strict scrutiny cases, modern courts under present-day Supreme Court doctrine ask whether a law that makes a suspect classification serves a compelling government interest pursued under the least restrictive

\footnotetext{
${ }^{450}$ Barbier, 113 U.S. at 32.

${ }^{451} 198$ U.S. 45 (1905).
} 
means. ${ }^{452}$ Under a Nineteenth Century class legislation approach of the kind originally imposed by the Fourteenth Amendment, a court would ask the slightly different question whether the law served a public and not some private purpose, and not just whether the law was justified by a compelling government interest. The distinction between the Nineteenth Century test and the modern test could prove critical in affirmative action cases where the legislature seeks to help a disadvantaged group. Otherwise, the modern strict scrutiny analysis is consistent with the Fourteenth Amendment's ban on class legislation as long as one recognizes that religion is every bit as much of a suspect classification as are race and sex.

\section{B. Modern Case Law and Class Legislation}

The Fourteenth Amendment's ban on class legislation includes a ban on facial discrimination targeting a specific class. This approach is consistent with the Supreme Court's case law that, for instance, a racial classification, regardless of purported motivation, is presumptively invalid. ${ }^{453}$ Thus segregation and Jim Crow laws easily fall into the category of forbidden class legislation. Anti-miscegenation laws are also invalid because they define legal rights based on race. ${ }^{454} \mathrm{~A}$ white person is allowed to marry another white person but a black person does not have that same right. ${ }^{455}$ In the context of religion, the court has also recognized that "the minimum requirement of neutrality is that a law not discriminate on its face." 456 Thus, in McDaniel v. Paty, the Supreme Court struck down as unconstitutional a law barring ministers from holding public office. ${ }^{457}$

\footnotetext{
${ }^{452}$ See Adam Winkler, Fatal in Theory and Strict in Fact: An Empirical Analysis of Strict Scrutiny in the Federal Courts, 59 Vand. L. Rev. 793, 798-801 (2006) (discussing the standard for strict scrutiny and various cases).

${ }^{453}$ Brown, 347 U.S. 483.

${ }^{454}$ See Calabresi \& Matthews, supra note 31 (arguing that Loving v. Virginia was consistent with the original meaning of the Fourteenth Amendment, which banned all class legislation).

${ }^{455} \mathrm{Id}$.

${ }^{456}$ Church of Lukumi Babalu Aye, Inc. v. City of Hialeah, 508 U.S. 520, 533 (1993).

${ }^{457}$ McDaniel, 435 U.S. at 626-29.
} 
The constitutional ban on class legislation includes some forms of legal discrimination amongst religious groups. Courts have appropriately considered these cases on equal protection grounds. For instance, in Native Am. Council of Tribes v. Solem, the Eight Circuit held that restrictions on Native American inmates' religious practices violated the Equal Protection Clause because similar restrictions did not exist for other religious groups. ${ }^{458}$ And in Colorado Christian Univ. v. Weaver, then-Judge Michael W. McConnell's opinion struck down a state educational funding scheme that permitted public money to go to religious schools but barred it from going to "pervasively sectarian" schools. ${ }^{459}$ Although the Tenth Circuit held that the law in question violated the Establishment Clause, it also declared that discrimination on the basis of religion is subject to "heightened scrutiny" and could violate the Equal Protection Clause. ${ }^{460}$ The Tenth Circuit also said that "neutral treatment of religions" is a requirement of the Equal Protection Clause, just as it is of the Establishment Clause. ${ }^{461}$

The ban on class legislation is also consistent with the Supreme Court's approach to facially neutral laws, which serve as a pretext for improper discrimination when the laws are administered. For instance, in 1886, in Yick Wo v. Hopkins, the Supreme Court held that an ordinance prohibiting the operation of laundry businesses in wooden buildings was unconstitutional because it was only enforced in practice against Chinese immigrants. ${ }^{462}$ The Court dutifully noted that the Fourteenth Amendment banned class legislation and held that the ordinance violated the Equal Protection Clause because it was enforced improperly by drawing an "arbitrary line" between "two classes," even though the underlying law did not facially

\footnotetext{
${ }^{458} 691$ F.2d 382, 384 (8th Cir. 1982).

459534 F.3d 1245.

${ }^{460} \mathrm{Id}$. at 1266.

461 Id. at 1257.

462118 U.S. 356 (1886).
} 
discriminate on the basis of race or national origin. ${ }^{463}$ In Washington v. Davis, the Supreme

Court held that evidence of discriminatory intent was necessary to prove that a facially neutral law violated the Equal Protection Clause even when the law in question had a racially disparate impact and was not justified by a compelling governmental interest. ${ }^{464}$ The Supreme Court later made it clear that a plaintiff need not prove that a law is motivated "solely [by] racially discriminatory purposes" but simply that improper discrimination was a motivating factor. ${ }^{465}$ In Village of Arlington Heights v. Metropolitan Housing Development Corp., the Supreme Court laid out a variety of factors that may be evidence of discriminatory intent. ${ }^{466}$ "Once racial discrimination is shown to have been a substantial or motivating factor behind enactments of law, the burden shifts [from the plaintiff] to the law's defenders to demonstrate that the law would have been enacted without this factor." ${ }^{467}$ Those holdings are consistent with Yick Wo and the original meaning of the Amendment's ban on class legislation. ${ }^{468}$

In the context of racial discrimination and private sector employment contracts, the Civil Rights Act of 1964 has always barred discrimination on the basis of religion as well as on the basis of race and sex. The Supreme Court held in Griggs v. Duke Power Co. that if an employer's hiring criteria disparately impacts a particular racial group, the employer bears the

\footnotetext{
${ }^{463}$ Id. at 367-368, 373-374.

464 Washington v. Davis, 426 U.S. 229 (1976).

465 429 U.S. 252, 265 (1977).

466 In Arlington Heights, the court provided a non-exhaustive list: (1) disparate impact on a particular race; (2) the historical background of the law, "particularly if it reveals a series of official actions taken for invidious purposes;" (3) the sequence of events leading up to the action taken; (4) departures from the normal procedural sequence; (5) substantive departures, "particularly if the factors usually considered important by the decision-maker strongly favors a decision contrary to the one reached;" and (6) the legislative or administrative history of the action. 429 U.S. at 267-268.

${ }^{467}$ Hunter v. Underwood, 471 U.S. 222, 228 (1985).

468 See Yick Wo, 118 U.S. at 374 ("The fact of this discrimination is admitted. No reason for it is shown, and the conclusion cannot be resisted that no reason for it exists except hostility to the race and nationality to which the petitioners belong, and which, in the eye of the law, is not justified. The discrimination is therefore illegal, and the public administration which enforces it is a denial of the equal protection of the laws, and a violation of the fourteenth amendment of the constitution.")
} 
burden of showing that the hiring criteria has a "manifest relationship to the employment in question" and is justified by business necessity. ${ }^{469}$

When inspecting facially neutral laws for signs of discrimination on the basis of religion, the Court has transplanted its analysis from its race and sex discrimination cases. As Justice Harlan noted in the context of the Establishment Clause, "neutrality in its application requires an equal protection mode of analysis." ${ }^{470}$ In Church of Lukumi Babalu Aye v. City of Hialeah, the Supreme Court said, "The Free Exercise Clause, like the Establishment Clause, extends beyond facial discrimination. The Clause forbids subtle departures from neutrality ... [and] protects against governmental hostility which is masked as well as overt." ${ }^{" 471}$ The Church of the Lukumi Babalu Court went on to use the Arlington Heights factors to show that a facially neutral City of Hialeah ordinance banning animal sacrifice was enacted for the purpose of discriminating unconstitutionally on the basis of religion and thus abridging Free Exercise Clause rights. ${ }^{472}$

Much of the Supreme Court's use of the Fourteenth Amendment to strike down various impermissible classifications in the 1970's, 1980's, and 1990's is also quite consistent with our view that the Fourteenth Amendment enacts a general ban on class legislation and systems of caste. Discrimination based on national origin, gender, ${ }^{473}$ illegitimacy, ${ }^{474}$ and many kinds of physical disability ${ }^{475}$ constitutes a caste system because these groups are defined in part by heredity or by immutable characteristics. The Court has also struck down some state laws

${ }^{469}$ Griggs v. Duke Power Co., 401 U.S. 424, 432 (1971).

${ }^{470}$ Walz v. Tax Comm'n of New York City, 397 U.S. at 696 (concurring opinion).

${ }^{471}$ Lukumi, 508 U.S. at 534 ("Here, as in equal protection cases, we may determine the city council's object from both direct and circumstantial evidence.") (citing Arlington Heights).

${ }^{472}$ Lukumi, 508 U.S. at 540.

${ }^{473}$ Craig, 429 U.S. 190; Frontiero, 411 U.S. 677; Virginia, 518 U.S. 515.

${ }^{474}$ Weber, 406 U.S. 164; Gomez, 409 U.S. 535; Trimble, 430 U.S. 762.

475 City of Cleburne, 473 U.S. 432 (holding that denial of zoning permit to home for mentally retarded individuals failed rational basis test under the Equal Protection Clause); but see Id. (Marshall, J. dissenting in part and concurring in the judgment) (arguing that mentally retarded individuals should be considered a suspect class due to history of discrimination and strict scrutiny analysis should apply). 
discriminating on the basis of citizenship. We think that, while some such state laws may be preempted by federal law, state laws that discriminate on the basis of citizenship should not for that reason be held to violate the Fourteenth Amendment's anti-discrimination command. As already discussed, the Privileges or Immunities Clause was quite deliberately written to protect only citizens from the making of discriminatory laws, and it implicitly permits the making of discriminatory laws that facially discriminate against non-citizens. ${ }^{476}$ Non-citizens are protected by the Due Process and Equal Protection Clauses, which apply to all persons and not merely to all citizens. We therefore think that In re Griffiths, in which the Supreme Court held that a state could not condition admission to the bar on citizenship, ${ }^{477}$ was inconsistent with the original meaning of the Fourteenth Amendment. But we think that Plyler v. Doe, a case in which the Supreme Court held that a school district could not charge children of illegal immigrants tuition, presents a closer call because those children were persons who were entitled to the equal protection of the state laws setting up free public schools. ${ }^{478}$

In the 1960s and 1970s, there was something of a movement to constitutionalize a right to receive welfare payments. Professor Frank Michelman has been a major advocate of constitutional rights to welfare, arguing that the equality principles of the Fourteenth Amendment require the government to pay money to the poor. ${ }^{479}$ Professor Michelman's argument is essentially a liberal form of Lochner. Just as Lochner tried to constitutionalize laissez-faire economic theory, Professor Michelman attempts to constitutionalize the post-New Deal and Great Society welfare state, perhaps even to give a major impetus to further efforts to

${ }^{476}$ See supra Part I.A.

477413 U.S. 717.

478457 U.S. 202.

${ }^{479}$ Frank I. Michelman, The Supreme Court, 1968 Term-Foreword: On Protecting the Poor Through the Fourteenth Amendment, 83 Harv. L. Rev. 7 (1969); Frank I. Michelman, In Pursuit of Constitutional Welfare Rights: One View of Rawls' Theory of Justice, 121 U. Pa.. L. Rev. 962 (1973). The Supreme Court appeared sympathetic to Michelman's philosophy in Goldberg v. Kelly, in which the court held that a welfare recipient had a right to a hearing before being deprived of welfare benefits. 397 U.S. 254 (1970). But the Court never went further. 
achieve socialism. Professor Michelman's argument that the government has a constitutional obligation under the Fourteenth Amendment to pay money to a group of people based on circumstances not caused by the government seems to us to be wrong and is not to be found anywhere in the Constitution's text or history. Even the recovery by private citizens of money from the federal government in Bivens actions requires that the federal government have directly caused the physical damage that is the basis of a lawsuit to a specific individual. ${ }^{480}$ And Congress had to pass Section 1983 to make state officials similarly liable for money damages when they cause an injury. But nowhere in the Constitution is there any notion of government liability to pay money of the kind Professor Michelman describes. In fact, state welfare payments as they presently exist might have been originally considered an unconstitutional form of class legislation, since they single out poor individuals for unique, government-provided benefits.

We recognize that interpreting the Fourteenth Amendment to include a broad ban on all class legislation is to adopt an approach to the Amendment's anti-discrimination guarantee that is inconsistent with the legendary discussion in United States v. Carolene Products Footnote Four. In that footnote, the Supreme Court indicated that the Fourteenth Amendment's antidiscrimination command protects "discrete and insular minorities," elaborated by John Hart Ely. ${ }^{482}$ The language emphasizing protection only for discrete and insular minorities necessarily implies a narrow reading of the Fourteenth Amendment under which the Amendment's anti-discrimination command would not apply to women or other majority victims of class legislation. But the Supreme Court has rejected Ely's approach in

\footnotetext{
${ }^{480}$ See Bivens v. Six Unknown Named Agents, 403 U.S. 388 (1971).

${ }^{481}$ Carolene Products Co., 304 U.S. at 153, n.4.

482 JOHN HART ELY, DEMOCRACY AND DISTRUST: A THEORY OF JUDICIAL REVIEW (1980).
} 
recent years ${ }^{483}$ and the Court has decided many recent Fourteenth Amendment cases without even citing the Carolene Products test. ${ }^{484}$

Moreover, the holding in Carolene Products is consistent with the notion that the Fourteenth Amendment bans class legislation generally. In Carolene Products, Congress prohibited shipments of a certain kind of imitation milk which it found could be "injurious to the public health, and its sale constitutes a fraud on the public." ${ }^{485}$ The law thus singled out sellers of imitation milk for a special burden, but it did so under a public purpose justification - public health concerns and protecting the public from fraud. Those are sufficient justifications for upholding the law; the Supreme Court was right in the Carolene Products case itself.

\section{Carolene Products Footnote Four and Religion}

More dramatically, United States v. Carolene Products Footnote Four explicitly declared that the Fourteenth Amendment bans discrimination on the basis of religion. In the third paragraph of Footnote Four, the Court said that a law would be "subjected to more exacting judicial scrutiny under the general prohibitions of the Fourteenth Amendment" if it was "directed at particular religious . . or national . . or racial minorities." 486 The Court thus explicitly understood the Fourteenth Amendment's anti-discrimination command as protecting individuals from laws that discriminate on the basis of religion, just as it protects individuals from laws that discriminate on the basis of national origin and race. And the Supreme Court made this observation about the ban on laws that discriminate on the basis of religion, even though the

\footnotetext{
${ }^{483}$ See, e.g., Regents of the University of California v. Bakke, 438 U.S. 265 (1978) (striking down an affirmative action program); Gratz v. Bollinger, 539 U.S. 244 (2003) (limiting an affirmative action program); Parents Involved, 551 U.S. 701 (applying strict scrutiny to an affirmative action program and striking down the program; Ricci, $129 \mathrm{~S}$. Ct. 2658 (striking down discrimination against whites).

${ }^{484}$ See, e.g., Frontiero, 411 U.S. 677; Reed v. Reed, 404 U.S. 71 (1971); Craig, 429 U.S. 190; Trimble, 430 U.S. 762; Romer, 517 U.S. 620; Ricci, 129 S. Ct. 2658.

${ }^{485}$ Carolene Products, 304 U.S. at 147.

${ }^{486} I d$. at 153 , n. 4 .
} 
Court had just finished saying in the first paragraph of Footnote Four that laws will be given less deference if they burden rights guaranteed by the Bill of Rights, which of course itself contains two Religion Clauses. If the Court had thought that religion was only protected under the Fourteenth Amendment as a consequence of its incorporation of the First Amendment, the Court would not have mentioned religion as a forbidden basis for discrimination after its initial reference to the Bill of Rights and the Religion Clauses in the first paragraph of Footnote Four. By listing religion in the third paragraph of Footnote Four, alongside national origin and race, the Supreme Court showed that religion was not merely protected by the First Amendment but was also protected by the anti-discrimination command of the Fourteenth Amendment. Strikingly, the Supreme Court listed discrimination on the basis of religion before both discrimination on the basis of national origin and discrimination on the basis of race, perhaps recognizing that first and foremost the anti-discrimination command of the Fourteenth Amendment bans discrimination on the basis of religion. The Supreme Court also failed to mention gender discrimination at all as being forbidden in Footnote Four, even though women had been guaranteed the right to vote for eighteen years before the Carolene Products case was decided. This too shows the unique constitutional weight that the Court attached to the protection of religious liberty under the Fourteenth Amendment.

Footnote Four also shows that the Fourteenth Amendment banned laws targeting all religion generally, and not just laws targeting specific religious groups. On its face, Footnote Four does not appear to stand for this proposition because the Supreme Court refers in Footnote Four to "particular religious ... minorities" $" 487$ which could be read to imply that the Fourteenth Amendment does not protect either religion generally or majority religions. But to support itself in Footnote Four, the Supreme Court approvingly cited Pierce v. Society of Sisters, a case ${ }^{487}$ Id. 
involving a law, which burdened all religious groups generally. In Society of Sisters, the State of Oregon had passed a law requiring all children between ages eight and sixteen to attend public school. ${ }^{488}$ The law did not provide exemptions for parents who wanted to send their children to private religious schools and thus created a substantial burden on all religious families and schools. ${ }^{489}$ The Supreme Court held that the law "unreasonably interfere[d] with the liberty of parents and guardians to direct the upbringing and education of children under their control., ${ }^{, 490}$ The Court therefore invalidated a law burdening all religious families and schools - whether minority or majority religions - without any discussion about the unique burdens on one particular religion. And the Carolene Products Court saw this Oregon law as the primary example of forbidden discrimination on the basis of religion under the Fourteenth Amendment. ${ }^{491}$ The court cited no other cases.

Even Footnote Four's famous language that “discrete and insular minorities” deserve special protection ${ }^{492}$ implicitly includes most religions, especially in the United States where there is no one majority faith. The words "discrete and insular" suggest that a targeted group must be distinct and narrowly defined for Footnote Four to apply. Religion as a whole in the United States does not fit this definition, but fervently religious groups, such as the Amish, Orthodox Jews, religious Muslims, or particular religious Christian groups, certainly could be included. And the words "discrete and insular" also could apply to groups that have historically suffered prejudice or stigma. The Supreme Court has used this approach to ban gender discrimination even though women constitute a majority of the U.S. population. ${ }^{493}$ Even

\footnotetext{
${ }^{488}$ Pierce v. Society of Sisters, 268 U.S. 510, 530 (1925).

${ }^{489}$ See Id. at 530-531.

${ }^{490} \mathrm{Id}$. at 534-35.

${ }^{491}$ Carolene Products, 304 U.S. at 153, n.4 (citing only Society of Sisters).

492 Carolene Products, 304 U.S. at 153, n.4.

${ }^{493}$ See Frontiero, 411 U.S. at 684-688 (discussing the "long and unfortunate history of sex discrimination").
} 
mainstream religious groups like Episcopalians, Catholics, Quakers, and Unitarians are minorities in the United States and would be protected under Footnote Four. If so, the many religious groups that have suffered persecution in this country all deserve Fourteenth Amendment protection. Even today, there is still much anti-religious bias and stigma attached to those who are religious and who profess their belief in a higher being. ${ }^{494}$

This observation leads us to discuss the majority opinion of the Supreme Court in City of Boerne v. Flores, the case which struck down as unconstitutional the Religious Freedom Restoration Act (RFRA) in so far as it applied to the states. Justice Kennedy's majority opinion in City of Boerne v. Flores explicitly questioned the extent to which discrimination on the basis of religion is still pervasive in this country. ${ }^{495}$ The Court noted that, in contrast to the Voting Rights Act context, Congress had produced no findings in passing RFRA of the existence of generally applicable laws motivated by religious bigotry that needed redressing in the forty years leading up to the passage of RFRA. ${ }^{496}$ Because of the lack of findings of religious discrimination, the Supreme Court questioned whether Congress had the power to create a prophylactic measure to protect religion under Section 5 of the Fourteenth Amendment. ${ }^{497}$ The Supreme Court essentially implied that reinstating the Sherbert-Yoder free exercise of religion balancing test ${ }^{498}$ was pointless because religious discrimination was not a real problem anymore.

The first problem with the Court's opinion in City of Boerne is that discrimination on the basis of religion is unfortunately alive and well in modern times. The Anti-Defamation League,

\footnotetext{
${ }^{494}$ See Tupi, supra note 356, at 242-262; Catholic League, 2011 Report on Anti-Catholicism, available at http://www.catholicleague.org/category/annual-report/2011-report-on-anti-catholicism/.

${ }^{495}$ See City of Boerne v. Flores, 521 U.S. 507, 530-531 (1997).

${ }^{496} I d$.

${ }^{497} I d$.

${ }^{498}$ See discussion of the Sherbert-Yoder Test infra Part IV.A.
} 
for example, reported 1,211 documented anti-Semitic incidents in the United States alone just in the year 2009. ${ }^{499}$ And the U.S. State Department reports that discrimination on the basis of religion and religious intolerance continue to be major worldwide concerns, including in many western democratic countries. ${ }^{500}$ It is quite reasonable to worry that anti-religious animus in society could seep into the legislative process and lead to the passage of neutral, generally applicable laws that have a discriminatory impact on religion. In fact, the Supreme Court had to strike down just such a discriminatory law in Church of the Lukumi Babalu when the City of Hialeah passed a facially neutral law targeting the animal sacrifice practices of members of the Santeria religion. While on the Third Circuit, then-Judge Samuel Alito wrote an opinion striking down a police department's policy of granting secular exemptions to its no-beard policy but refusing to grant exemptions for religious reasons. ${ }^{501}$ And in 2011, a local California ballot initiative seeking to ban circumcision had sponsors with anti-Semitic affiliations. ${ }^{502}$ Similarly, a city might seek to save money, not by explicitly banning religious individuals from public schools, but by making public schools so secular and so hostile to religion that religious parents would feel unable to let their children attend public schools. Concern exists over laws that discriminate on the basis of race and gender, and it is quite unclear why it should not also exist with respect to laws that discriminate on the basis of religion.

\footnotetext{
${ }^{499}$ Anti-Defamation League, 2009 Audit of Anti-Semitic Incidents (2009), available at http://www.adl.org/main_Anti_Semitism_Domestic/2009_Audit.htm.

${ }^{500}$ See U.S. DEPARTMENT OF STATE, http://www.state.gov/j/drl/rls/irf/2010_5/168441.htm (executive summary of worldwide findings). To select reports for individual countries, go to http://www.state.gov/j/drl/rls/irf/2010 5/index.htm.

$\overline{501}$ Fraternal Order of Police Newark Lodge No. 12 v. City of Newark, 170 F.3d 359 (3d Cir. 1999).

502 See DAILY MAIL REPORTER, “Circumcision should be banned but I don't 'have the time or energy': California mother drops bid to end the practice, http://www.dailymail.co.uk/news/article-2001035/California-mother-JenaTroutman-drops-bid-ban-circumcision.html\#ixzz1r0xqjaRF, available at http://www.dailymail.co.uk/news/article2001035/California-mother-Jena-Troutman-drops-bid-ban-circumcision.html (last visited April 3, 2012);
} 
And second, the Supreme Court's observation in City of Boerne that Congress did not present findings in that case of specific, neutral, generally applicable laws that had a discriminatory impact on religion should not have led to the Court's conclusion that RFRA was pointless. Quite possibly, few discriminatory laws were passed because judicial protections, such as the Sherbert-Yoder free exercise balancing test, and other laws, such as RFRA or its many state-level equivalents, had successfully deterred legislatures from discriminating on the basis of religion. Who knows what kind of havoc legislatures could potentially wreak in the absence of those deterrents? Even assuming that a lack of findings means that there is no actual problem of religious discrimination, why should the legislature be precluded from preemptively guarding against potential discrimination on the basis of religion? Just as many people proactively take care of their health, it seems sensible to proactively prevent discrimination on the basis of religion before it actually happens. And finally, the Supreme Court's evaluation of discrimination on the basis of religion fails to take into account the plethora of Blaine Amendments in a huge majority of state constitutions which explicitly ban government funds from going to any religious organizations ${ }^{503}$ - a degree of facial discrimination unheard of today with regards to race. So the Court's conclusion that RFRA cannot be justified is simply incorrect.

The upshot of our discussion of Carolene Products is that using the Fourteenth Amendment to ban discrimination on the basis of religion does not contradict the modern Equal Protection Clause case law. Footnote Four explicitly said that the Fourteenth Amendment protects all of us from discrimination on the basis of religion, just as it protects all of us from discrimination on the basis of national origin and race. ${ }^{504}$ And "discrete and insular minorities" certainly include religious minorities, even assuming that discreteness and insularity are

\footnotetext{
${ }^{503}$ See infra (discussing Blaine Amendments).

${ }^{504}$ Carolene Products Co., 304 U.S. at 155 n.4
} 
important to anti-discrimination law - a conclusion which we tend to doubt. The Supreme Court recognized in Carolene Products that religion gets Fourteenth Amendment anti-discrimination protection, even though religion also gets strict scrutiny as a result of its inclusion in the Religion Clauses of the Bill of Rights. ${ }^{505}$ Subsequent Supreme Court opinions have enshrined religion in the Fourteenth Amendment with almost ritualistic statements that "[ $t]$ he Equal Protection Clause prohibits selective enforcement based upon an unjustifiable standard such as race, religion, or other arbitrary classification." 506 In Kiryas Joel, Justice Sandra Day O'Connor said, "the Religion Clauses-the Free Exercise Clause, the Establishment Clause, the Religious Test Clause, ... and the Equal Protection Clause as applied to religion-all speak with one voice on this point: Absent the most unusual circumstances, one's religion ought not affect one's legal rights or duties or benefits."

These statements show that many contemporary courts and Supreme Court justices are not at all restrained in invoking the Fourteenth Amendment's anti-discrimination command to answer questions involving religious liberty. The Supreme Court has never said that the Fourteenth Amendment's anti-discrimination command does not apply to discrimination on the basis of religion or that the First Amendment Religion Clauses must be used to answer all constitutional questions as to the scope of religious liberty. So, the Supreme Court or even lower federal and state courts could simply start using the Fourteenth Amendment's anti-discrimination command today in cases where there has been discrimination on the basis of religion.

\footnotetext{
${ }^{505} I d$.

${ }^{506}$ See Batchelder, 442 U.S. at 125 n.8 (citing Oyler, 368 U.S. at 456) (emphasis added); see also Armstrong, 517 U.S. at 464; Abcarian, 617 F.3d at 938 (citing Engquist, 553 U.S. at 596; Plyler, 457 U.S. at 216-17 (stating that "[t]he Equal Protection Clause of the Fourteenth Amendment most typically reaches state action that treats a person poorly because of the person's race or other suspect classification, such as sex, national origin, religion, political affiliation, among others, or because the person has exercised a "fundamental right," or because the person is a member of a group that is the target of irrational government discrimination).

${ }^{507} 512$ U.S. at 715 (O'Connor, J., concurring)).
} 


\section{The Free Exercise and Establishment Clauses after the Fourteenth Amendment}

We now consider the impact that the Fourteenth Amendment's general antidiscrimination command had or should have had on the interpretation of the Free Exercise and Establishment Clauses, which are incorporated through Fourteenth Amendment substantive due process to apply against the states. ${ }^{508}$ Because both the Free Exercise Clause and the Establishment Clause were really bans on certain specific forms of discrimination on the basis of religion, it is vital that we ask whether and how the adoption of the Fourteenth Amendment's general ban on discrimination on the basis of religion affects the Supreme Court's present-day Free Exercise Clause and Establishment Clause jurisprudence. To answer this question, we think it is helpful to focus on the definition of class legislation and on the evils that the Framers of the Fourteenth Amendment sought to eradicate by constitutionalizing a ban on class legislation. It is also vital that we remember that the Fourteenth Amendment forbade discrimination on the basis of religion at the same time that it forbade other forms of discrimination as well.

We believe that the Fourteenth Amendment's general ban on discrimination on the basis of religion expanded the scope of Free Exercise Clause protections but that it did not enlarge the reach of the Establishment Clause. The Fourteenth Amendment requires that laws burdening religion or discriminating against religion must promote the general good of the whole people. This means that we should sometimes provide religious exemptions from facially neutral laws that effectively discriminate on the basis of religion because religious individuals and secular individuals are not similarly situated. But the Fourteenth Amendment's ban on class legislation on the basis of religion does not open the courtroom door to citizen suits in which a mere whiff of establishment was perceived, even though actual damages were never incurred and no litigant

\footnotetext{
${ }^{508}$ See Cantwell v. Connecticut, 310 U.S. 296, 303 (1940) (incorporating the Free Exercise Clause); Everson v. Board of Education, 330 U.S. 1, 15 (1947) (incorporating the Establishment Clause).
} 
has standing. Nor does it imply that we should scrub the public square free of all religious expression and symbols. To do that would be to actually discriminate on the basis of religion, which is precisely what the Fourteenth Amendment forbids. The Fourteenth Amendment was written to foster equality and liberty, not to repress it. Reexamination of the Supreme Court's Religion Clause case law is therefore warranted.

\section{A. Free Exercise Clause}

\section{Originalism and the Free Exercise Clause}

The Free Exercise Clause was originally meant to provide limited protection for the free exercise of religion. First, the Clause restrains Congress from passing certain kinds of laws, ${ }^{509}$ but it does not restrict actions taken by private citizens. ${ }^{510}$ In this sense, the Free Exercise Clause is quite different from the Thirteenth Amendment which guards against private actions.

Second, the Free Exercise Clause specifically restrains congressional law making but not federal judicial or executive law making. And the Free Exercise Clause says nothing about religious freedom and law enforcement discretion. The Free Exercise Clause thus contrasts with the Fourteenth Amendment which forbids the states from making or enforcing laws that abridge or shorten or lessen the rights or privileges or immunities of citizens on the basis of religion.

Third, the Free Exercise Clause only prevents Congress from making laws "prohibiting" or targeting the free exercise of religion, but the Clause does not on its face block laws that merely abridge or burden or infringe on religious liberties. ${ }^{511}$ Samuel Johnson's 1786 Dictionary

\footnotetext{
${ }^{509}$ U.S. CONST. amend. I, $\S 1$ ("Congress shall make no law . . prohibiting the free exercise [of religion].“)

${ }^{510}$ See Lash, supra note 354, at 1113 (making this argument and noting that the Clause addresses one of Madison's primary concerns about republican government which was to protect "citizens generally from government officials pursuing their own self-interested agendas at the expense of their constituents").

${ }^{511}$ See Id. (making this argument); Reynolds, 98 U.S. 145 (evaluating the original meaning of the Free Exercise Clause and holding that a law criminalizing polygamy did not violate the Free Exercise Clause because the law did not prohibit religious beliefs but religious acts). See generally Lyng v. Northwest Indian Cemetary Protective Association, 485 U.S. 439 (1988) (emphasizing the significance of the word "prohibit" in the Free Exercise Clause). Professor McConnell puts together an extensive analysis of this subject. See McConnell, supra note 309. McConnell
} 
and Noah Webster's 1828 Dictionary both defined "prohibit" as "to forbid; to interdict by authority. ${ }^{, 512}$ In 1856 , prohibit appeared to have the same meaning. ${ }^{513}$ The Free Exercise Clause thus contrasts with the Free Speech Clause which bars Congress from even "abridging the freedom of speech, or of the press; or the right of the people peaceably to assemble, and to petition the Government for a redress of grievances." ${ }^{, 514}$ Laws that limit access to government welfare benefits and to charity may "abridge" the free exercise of religion, but it is hard to say that they "prohibit it". The original meaning of the Free Exercise Clause thus is hard to square with Sherbert v. Verner, ${ }^{515}$ although that case is consistent with the Fourteenth Amendment's anti-discrimination command.

Finally, there is considerable debate over what kinds of religious activity the Free Exercise Clause protects. In Reynolds v. United States, the Supreme Court said that the Free Exercise Clause only protected rights of conscience, ${ }^{516}$ which probably also included a right to take action by worshiping in ceremonies of worship. ${ }^{517}$ The Clause does after all on its face protect the free "exercise" of religion and not merely "freedom of conscience" or "belief." It

notes that the word "infringing" was initially proposed but was replaced with "prohibiting." Id. at 1486. McConnell also cites a report of the Department of Justice that the original meaning of the Clause only prevents Congress from passing laws that prohibit the free exercise of religion. Id. Yet, somewhat curiously, McConnell ultimately concludes that the Free Exercise Clause bars even laws abridging or infringing on religion, not just those prohibiting it. See Id. at 1487-1488.

${ }^{512}$ SAMUEl JohnSOn, DictionaRy OF THE ENGlish language (Harrison \& Co., 1786) [hereinafter "SAMUel JOHNSON'S 1786"]; WEBSTER's 1828, supra note 52 (defining "prohibit" as:

1. To forbid; to interdict by authority; applicable to persons or things, but implying authority or right. God prohibited Adam to eat of the fruit of a certain tree. The moral law prohibits what is wrong and commands what is right. We prohibit a person to do a thing, and we prohibit the thing to be done.

2. To hinder; to debar; to prevent; to preclude."

${ }^{513}$ See Goodrich, supra note 38, at 358 (defining "prohibit" as "to interdict by authority; as the law prohibits what is wrong. - syn. To Forbid").

${ }^{514}$ U.S. CONST. amend. I, § 1.

515374 U.S. 398 (1963) (striking down the denial of unemployment compensation to someone who was lost their job for religious reasons).

51698 U.S. 145, 164 (1879).

${ }^{517}$ See McConnell, supra note 309, at 1507-1509 (discussing rights to conscience and worship) 
strains credulity not to read the Free Exercise Clause as at least protecting a right to take action in ceremonies of worship and to decline to serve in the military. But Professor Michael McConnell has argued much more boldly that the Free Exercise Clause protects not only the taking of action in ceremonies of worship but also all other religiously motivated conduct as well. ${ }^{518}$ McConnell's view is based on the fact that initial drafts of the Free Exercise Clause protected only "rights of conscience," while the final draft more broadly protected the "free exercise of religion." Dictionary definitions at the time of the Framing defined the word "exercise" as involving the "labour of the body" or other physical activities, whereas the word "conscience" was restricted to apply only to "private thoughts" or "knowledge.",519

\section{Role of the Anti-discrimination Command of the Fourteenth Amendment on Free Exercise questions}

After ratification of the Fourteenth Amendment, analysis of the incorporated Free

Exercise Clause should have changed to take into account the Amendment's ban on all forms of discrimination on the basis of religion. We agree with Bernadette Meyler that the courts should have taken an equal protection approach to free exercise claims, but we disagree with her as to the doctrinal test that should be used. ${ }^{520}$ Instead of inquiring whether a congressional action

\footnotetext{
${ }^{518}$ See Id. at $1488-1490$.

${ }^{519}$ McConnel reports:

The choice of the words "free exercise of religion" in lieu of "rights of conscience" is therefore of utmost importance. As defined by dictionaries at the time of the framing, the word "exercise" strongly connoted action. The American edition of Samuel Johnson's Dictionary of the English Language, published in Philadelphia in 1805, used the following terms to define "exercise": "Labour of the body," "Use; actual application of any thing," "Task; that which one is appointed to perform," and "Act of divine worship, whether public or private." Noah Webster's American dictionary defined "exercise" as "employment." James Buchanan's 1757 dictionary defined "exercise" as "to use or practice." "Conscience" was more likely to have been understood as opinion or belief. Johnson equated "conscience" with the terms "knowledge," "Real sentiment; veracity; private thoughts," "Scruple; difficulty," and "reason; reasonableness." Webster defined it as "natural knowledge, or the faculty that decides on the right or wrong of actions." Buchanan defined it as the "testimony of one's own mind."

Id. at 1489 (citing various dictionaries).

${ }^{520}$ Meyler, supra note 17.
} 
prohibited the free exercise of religion, we think the Supreme Court should instead have asked whether a state law abridging religious freedom was a forbidden form of class legislation that discriminated on the basis of religion. As with any other form of forbidden class legislation, the Court must consider two questions: 1) does the law or government action discriminate on the basis of religion, and 2) is there a public purpose served by the law such that the law is a general law enacted for the good of the whole people? To be clear, granting a specific religious group a unique privilege or immunity simply because the government wants to help that religion perhaps in an attempt to rectify past discrimination or out of sympathy for its current unpopularity - is not a law that should be seen as having a legitimate public purpose. Similarly, dishing out unique burdens simply because a particular religion does not comport with majoritarian norms is also unacceptable. A law serves a public purpose and is not class legislation when it is designed to benefit society as a whole and not just a special interest group. Additionally, since the free exercise of religion is undoubtedly a fundamental right - enshrined in the text of the Bill of Rights and guarded in three clauses in the Constitution and in the Bill of Rights - a court should subject any law that abridges religious liberty to strict scrutiny. ${ }^{521}$ This is doubly the case since most religions in the United States are arguably discrete and insular minorities that qualify yet again for protection via strict scrutiny under Carolene Products Footnote Four. Accordingly, a court should evaluate laws that abridge religious liberty by asking whether the government interest underlying the law is being pursued using the least restrictive means and whether the law in question benefits the general public as a whole.

The easiest application of the ban on class legislation that discriminates on the basis of religion is to laws that are facially neutral but that are clearly intended to discriminate against religion. For instance, in Church of the Lukumi Babalu, the Supreme Court unanimously struck

\footnotetext{
${ }^{521}$ See Infra p. 96-103.
} 
down a city ordinance banning animal sacrifice. ${ }^{522}$ The legislative history showed that the city council passed the law in question in response to the practice of adherents of the Santeria religion who performed animal sacrifice in their ritual ceremonies of worship. ${ }^{523}$ This law was rightly held to be a violation of the Free Exercise Clause. It also violates the anti-discrimination command of the Fourteenth Amendment because: 1) it directly discriminates against religion, and 2) it lacks a public purpose because it fails to serve the general good of the whole people. The ban on animal sacrifice should have been subjected to strict scrutiny, which it could not possibly have survived.

Constitutional analysis gets harder when courts are asked to assess a facially neutral and generally applicable law that lacks any specific anti-religious intent but which uniquely burdens religion. Whether the Free Exercise Clause mandates religious exemptions from facially neutral laws is a question that has triggered considerable scholarly debate. ${ }^{524}$ The Supreme Court has taken two divergent approaches. A brief summary of the Court's case law in this area is necessary.

522 508 U.S. 520.

${ }_{523}^{52} \frac{58 \text {. at } 526-528 .}{\text { P. }}$

${ }^{524}$ Philip A. Hamburger explains that the framers believed that exemptions were unnecessary because civil government and religion served different roles and simply operated in different jurisdictions. A Constitutional Right of Religious Exemption: An Historical Perspective, 60 Geo. Wash. L. Rev. 915, 936-37 (1992). Religious dissenters around the time of the framing sought an end to establishments but did not seek exemptions. Id. at 946. And the notion that individuals might have a right to religious exemptions from generally applicable civil laws was so bizarre that supporters of religious establishments used the notion to smear anti-establishment proponents. Id. at 941. In his concurrence in City of Boerne, Justice Scalia noted that in the years following ratification of the Constitution there is no record of any state or federal cases in which a court struck down a generally applicable law because it failed to provide a religious exemption. 521 U.S. at 542 (Scalia, J., concurring) But there were at least two cases in which a religious exemption was denied. Id. at 543. But see McConnell, supra note 310_(arguing that the Free Exercise Clause required religious exemptions, as long as those exemptions did not interfere with the peace or important government interests); City of Boerne,521 U.S. at 546-565 (O'Connor, J., dissenting) (arguing that the court should return to its pre-Smith jurisprudence in which it balanced the government interest against the burden on religious exercise because the Free Exercise Clause created "an affirmative guarantee of the right to participate in religious practices and conduct without impermissible governmental interference, even when such conduct conflicts with a neutral, generally applicable law"). 
Until 1990, the Supreme Court generally balanced the government interest in adopting a facially neutral law that burdened religion against the severity of the burden imposed on the religious individuals who were forced to choose between complying with the law and sacrificing their religious beliefs. ${ }^{525}$ In Sherbert v. Verner, as was mentioned above, the Supreme Court held that the denial of unemployment benefits to Seventh Day Adventist who would not work on Sabbath violated the Free Exercise Clause, even though the law in question was religion-neutral, facially neutral, and applied to all citizens generally. ${ }^{526}$ The Court explained that depriving a religious individual of unemployment benefits if he or she was fired for refusing to work on the Sabbath placed him or her in the uncomfortable position of having to choose between his or her religion and the government welfare benefits in question. ${ }^{527}$ In holding that such governmental pressure violated the Free Exercise Clause, the Sherbert Court laid down a two-step test for evaluating Free Exercise Clause claims. First, does the government action in question substantially burden an individual's ability to exercise his or her religious belief? ${ }^{528}$ And second, does the government have a compelling state interest that overrides the individual's religious liberty claim? ${ }^{529}$ The Supreme Court implied that these two questions were interrelated and that they required balancing the importance of the government interest in question against the degree to which the free exercise of religion was impaired. ${ }^{530}$ The answer to this question depended in part on whether the government pursued its compelling objective in the least restrictive way. In Wisconsin v. Yoder, the Supreme Court used the Sherbert balancing test to hold that Amish parents could not be compelled to send their children to school past the eighth grade. ${ }^{531}$

\footnotetext{
${ }^{525}$ See Sherbert, 374 U.S. 398; Thomas, 450 U.S. 707.

${ }^{526}$ Sherbert, 374 U.S. at 410.

${ }^{527}$ Id. at 404.

${ }^{528} I d$. at $403-404$.

${ }^{529} \mathrm{Id}$. at 406-407.

${ }^{530}$ See 6 TREATISE ON CONST. L. $§ 21.8$ (b) (4th ed.) (discussing).

531 406 U.S. 205 (1972).
} 
The court explained that the government's interest in forcing Amish children to attend ninth and tenth grades was not sufficiently compelling relative to the substantial burden the law imposed on Amish parents' religious beliefs. ${ }^{532}$ Sherbert and Yoder thus seemed to herald the dawn of a new age in which the Free Exercise Clause would be read broadly as protecting the access of religious people to welfare benefits and to their own ideas about the education of children.

In its 1990 decision in Employment Division, Dept. of Human Resources v. Smith, however, the U.S. Supreme Court abruptly changed course 180 degrees. The Court in Smith rejected the Sherbert-Yoder balancing test and held that facially neutral criminal laws banning the use of peyote in religious ceremonies did not need to be accompanied by a religious exemption under the Free Exercise Clause. ${ }^{533}$ The Court declared that facially neutral laws that prohibit action in a religious ceremony do not violate the Free Exercise Clause, as long as they do not target a specific religious group, even though specific religious groups or religious people in general might face a significant burden on their religious beliefs or practices. ${ }^{534}$

In 1993, in the wake of the Smith decision, Congress passed the Religious Freedom Restoration Act (RFRA), which purported to reinstate the Sherbert-Yoder balancing test. ${ }^{535}$ RFRA said that the "Government shall not substantially burden a person's exercise of their religion even if the burden results from a rule of general applicability." ${ }^{, 536}$ If a government action does burden religious exercise, it must satisfy strict scrutiny. Namely, the government action must 1) further a compelling government interest, and 2) accomplish its goal with the least restrictive means. ${ }^{537}$ RFRA applied to both the states and the federal government. Congress

\footnotetext{
${ }^{532} I d$. at $217-218$.

${ }^{533}$ Employment Division, Dept. of Human Resources v. Smith, 494 U.S. 872 (1990).

${ }^{534}$ Smith, 494 U.S. at $877-878$.

53542 U.S.C. $\S 2000 \mathrm{bb}-1$ (invalidated by City of Boerne, 521 U.S. 507).

${ }^{536} \mathrm{Id}$.

${ }^{537} I d$.
} 
justified RFRA on the grounds that it was overturning Smith and enforcing the Free Exercise Clause as incorporated through the Fourteenth Amendment under its Section 5 power to enforce the Fourteenth Amendment. ${ }^{538}$

In City of Boerne v. Flores, the Supreme Court struck down RFRA as it applied to the states. ${ }^{539}$ The Court explained that Congress could only enforce the Free Exercise Clause if there was "congruence and proportionality between the injury to be prevented or remedied and the means adopted to that end." 540 The Supreme Court said that Congress could not legislatively "overturn" a Supreme Court decision like the one in Smith and that it could not invent a new substantive right restricting state governments while pretending to "enforce" the Fourteenth Amendment. ${ }^{541}$ The Supreme Court did not, however, strike down RFRA's application to the federal government, ${ }^{542}$ and in a later case the Court unanimously held that RFRA was valid as to the federal government. ${ }^{543}$ Thus the Obama Administration's recent decision to force all organizations - whether religious or not - to provide contraceptive coverage to their employees $^{544}$ will have to survive strict scrutiny under RFRA.

We think that Justice Scalia's approach in Smith is open to two criticisms. First, on the facts of Smith, a group of Native Americans was barred from ingesting peyote in a religious ceremony of worship because of state anti-narcotics laws. The constitutionality of this law seems dubious because the Native Americans literally wanted to engage in the exercise of religious worship, which is precisely the primary type of "exercise" that the Free Exercise Clause protects.

\footnotetext{
${ }^{538}$ City of Boerne, 521 U.S. at 507-508.

${ }^{539}$ Id. at 508 .

${ }^{540} \mathrm{Id}$.

${ }^{541} I d$.

${ }^{542} I d$.

${ }^{543}$ See Gonzales v. O Centro Espirita Beneficente Uniao do Vegetal, 546 U.S. 418 (2006).

${ }^{544}$ Richard Wolf \& Cathy Grossman, Obama mandate on birth control coverage stirs controversy, USA TODAY, Feb. 9, 2012, available at http://www.usatoday.com/news/washington/story/2012-02-08/catholics-contraceptivemandate/53014864/1.
} 
Allowing the government to simply declare a mode of worship illegal appears to gut the Free Exercise Clause of any meaning. And the Native American worship did not harm any third parties as might a human sacrifice in a Neo-Aztec ceremony of worship or the burning of a widow on her husband's funeral pyre as in the ancient Asian Indian practice called suttee. Justice Scalia thus seems wrongly to say in Smith that the Free Exercise Clause actually protects only freedom of conscience and not the "exercise" of any religious liberties.

Second, Justice Scalia's opinion in Smith seems to imply that so long as a law is facially neutral and is motivated by no discriminatory intent it will survive Free Exercise Clause scrutiny. This seems to us to be plainly wrong. A law can be facially neutral but still be discriminatory if it is written in a way that targets a suspect class or that treats unlike things as if they are like things. The laws in the South in the 1880 's that allowed anyone to vote whose grandfathers had been eligible to vote were facially neutral, but they were also plainly designed to discriminate on the basis of race. Similarly, laws today that require that all healthcare providers fund access to contraceptives and abortion discriminate on the basis of religion even if they are written in a way that is facially neutral. These are all facts that everyone in society just knows, and they arise from the fact that since religious people and secular people are different in some respects a law that treats them as if they were exactly the same is in fact discriminatory. This phenomenon was mentioned as long ago as by Aristotle in The Politics:

"[T]he political good is justice, and justice is the common benefit. Now everyone holds that what is just is some form of equality .... For justice is something to someone, and they say it should be something equal to those who are equal. But equality in what and inequality in what, should not be overlooked. For this involves a problem and political philosophy." 545

The basic point is that a law that requires that everyone take Sunday as their legal day of rest may be facially neutral and nondiscriminatory, and it may not even by motivated by a

${ }^{545}$ ARISTOTLE, The Politics BooK III, Ch. 12, lines 1282 b 14 to 23. Translated by C.D.C. Reeve (1998). 
discriminatory intent. But such a law does in fact discriminate on the basis of religion to the detriment of Jews and Muslims.

We think that Justice Scalia was quite properly concerned in Smith by his correct dislike for disparate impact analysis in Title VII race discrimination cases where the Supreme Court held that whenever an employment practice had a racially disparate impact the practice was unlawful unless the defendant could prove it was justified by business necessity. ${ }^{546}$ Early in his tenure on the Supreme Court, Justice Scalia joined an important opinion in Wards Cove Packing Co. v. Atonio ${ }^{547}$ which sought to limit disparate impact analysis and which Congress then tried to overturn by passing the Civil Rights Act of 1991. In his separate concurrence in Ricciv. DeStefano, ${ }^{548}$ Justice Scalia even asked whether Title VII disparate impact analysis might itself violate constitutional equal protection doctrine, which has been held since Washington $v$. Davis $^{549}$ to require proof of discriminatory intent as well as disparate impact. Disparate impacts often emerge for totally benign reasons, and we think it is a huge mistake in race discrimination or religion discrimination cases to shift the burden of proof only because of a disparate impact.

The real question in any Fourteenth Amendment discrimination case is whether the government has denied to any class of people the same legal rights as were held by white men under federal and state law in 1868. Members of every race, sex, and religion have the same legal rights, today, as were enjoyed by white men in 1868. A law is discriminatory under the Fourteenth Amendment without regard to proof of discriminatory intent or of disparate impact if it gives a class of people fewer legal rights than were enjoyed by white men in 1868. Citizens of every race, sex, and religion have, in the words of the Civil Rights Act of 1866, "the same

\footnotetext{
${ }^{546}$ Griggs v. Duke Power Co., 401 U.S. 424 (1971).

547490 U.S. 642 (1989).

548 129 S.Ct. 2658 (2009).

549426 U.S. 229 (1976).
} 
right[s]" as were enjoyed in the 1860 's by white citizens. ${ }^{550}$ Class legislation is unconstitutional unless it is in the form of a general law enacted for the good of the whole people, not a subsection of society. ${ }^{551}$

We think that disparate impact analysis in cases where discrimination on the basis of religion is alleged must take account of the fact that it is often well known how a facially neutral law will impact religion prior to its enactment. Because the discriminatory impact certain laws will have on a known religion is so obvious and inescapable, discriminatory intent can be more easily inferred in cases involving discrimination on the basis of religion than in cases involving discrimination on the basis of race. Justice Field discussed this issue while riding circuit in 1879 in Ho Ah Kow v. Nunan, a case in which the court struck down an ordinance that permitted prison guards to shave the heads of prisoners, even Chinese prisoners who wore a queue for religious reasons. ${ }^{552}$ In that case, the government was well aware that shaving the queues of Chinese individuals would violate their religious beliefs. ${ }^{553}$ Despite the possible benefits of the ordinance, Justice Field was disturbed by the way in which "the ordinance acts with special severity upon Chinese prisoners, inflicting upon them suffering altogether disproportionate to what would be endured by other prisoners if enforced against them. ${ }^{, 554}$ For that reason, the court struck down the ordinance as a violation of the Fourteenth Amendment's ban on class legislation discriminating on the basis of religion. ${ }^{555}$

If Justice Field had used the test of Employment Division v. Smith in Ho Ah Kow v. Nunan, the prison ordinance requiring the shaving of queues should have survived because it was

\footnotetext{
${ }^{550} 14$ Stat. 27-30, Apr. 9, 1866 A.D.

${ }_{551}^{55}$ Corfield v. Coryell, 6 Fed. CAS. 546 c.c.e.d. Pa. (1823).

552 12 F. Cas. 252 (C.C.D. Cal. 1879)

${ }_{553} \mathrm{Id}$. at 253 .

${ }^{554} \mathrm{Id}$. at $253,255$.

${ }^{555} \mathrm{Id}$. at 255 .
} 
a neutral, generally applicable law regarding hair length in prison. But Justice Field recognized that the disparate impact on Chinese religious practices was well known and severe and for that reason the law in question did constitute impermissible class legislation. Justice Field further discussed how a facially neutral law could be considered "legislation with a hostile intent" merely because of the "exceptional severity" such legislation inflicted on a particular class, such as believers in a minority religion. ${ }^{556}$ Justice Field described, for example, how a law requiring all prisoners to eat pork would violate the Fourteenth Amendment because of such a law's obvious disparate impact on observant Jews. ${ }^{557}$ Justice Field also said that laws "enacted with the avowed purpose of imposing special burdens and restrictions upon Catholics" would violate the Fourteenth Amendment, even if they were facially neutral. ${ }^{558}$

Justice Field's point is that the existence of certain religious practices is often well known before legislation is adopted, and for that reason severe disparate impacts on religion, unlike severe disparate impacts on the basis of race, can be easily predicted. We therefore think that the Fourteenth Amendment prevents lawmakers from simply ignoring obvious and inevitable disparate impacts that facially neutral laws will have on religion unless those laws are needed to avoid harm to some third party - for example, a widow being burned on the funeral pyre of her husband. But under Smith, the Supreme Court seemed to say that lawmakers could force Chinese prisoners to shave their heads, Jews to eat pork, and Catholics to pay for contraception and abortions, as long as the laws in question are facially neutral and generally applicable. We think that result is wrong and violates the Fourteenth Amendment for the reasons Justice Field gave in 1879.

\footnotetext{
${ }^{556}$ Id. at 255.

${ }^{557}$ Id. at 255 .

${ }^{558} \mathrm{Id}$. at 255-256.
} 
In Carolene Products Footnote Four, the U.S. Supreme Court said that the Fourteenth Amendment banned laws that disparately impact religion. As discussed earlier, Footnote Four cited one case, Pierce v. Society of Sisters, for the proposition that the Fourteenth Amendment banned discrimination on the basis of religion. ${ }^{559}$ In Society of Sisters, the Oregon law at issue was not one that facially discriminated against one religion or all religions. It was a facially neutral, generally applicable law that merely had a disparate impact on religion because it banned all private schools. The law in question applied to all school children, and the Court in Society of Sisters cited no examples of anti-religious animus or of discriminatory intent in the legislative history of the Oregon law. Yet the Carolene Products Court still cited the Oregon law struck down in Society of Sisters as the primary example of a law "directed at" religion in violation of the anti-discrimination command of the Fourteenth Amendment. ${ }^{560}$ Why would the Supreme Court cite a disparate impact case in discussing discrimination on the basis of religion when it cited a case of facial discrimination for race $?^{561}$ The Court did not explain itself, but we can speculate that perhaps the justices recognized that disparate impacts on religion were more common than facial discrimination on the basis of religion? Or perhaps the Supreme Court just took judicial cognizance of the fact that everyone knew that Catholic parochial schools were the real targets of the Oregon law no matter what the law said on its face. Or perhaps the Supreme Court recognized that facial discrimination against religion was already banned by the Free Exercise Clause of the First Amendment as it would be incorporated against the states, whereas the Fourteenth Amendment's anti-discrimination command outlawed disparate impacts on religion as well as laws that discriminated on their face. Whatever the reason, Carolene Products Footnote Four reflects the U.S. Supreme Court's acknowledgment in a seminal opinion that the

\footnotetext{
${ }_{559}^{55 e e ~ s u p r a ~ P a r t ~ I I I . C . ~}$

${ }^{560} I d$.

${ }^{561}$ See Id. (citing Nixon v. Herndon, 273 U.S. 536 (1927), involving a law that facially discriminated based on race).
} 
Fourteenth Amendment's anti-discrimination command broadly bans all discrimination on the basis of religion, just as it bans all discrimination on the basis of national origin or race.

We think that, instead of using the Smith rule, the Supreme Court should say that the Fourteenth Amendment's anti-discrimination command as applied in the context of religion mandates a variation of the Sherbert-Yoder balancing test. First, the Fourteenth Amendment's ban on discrimination on the basis of religion means that a law discriminating on the basis of religion can only be upheld if it promotes the general good of the whole people. The SherbertYoder test merely required that a law burdening religion pursue an important government interest. Second, we also think that the Fourteenth Amendment demands an evaluation of the degree of harm to religious citizens that is inflicted by the law in question as well as by the need to protect a vulnerable third party from actual physical harm. Courts should take into account the magnitude of the harm inflicted on religion, as the Supreme Court did in its equal protection decision in Skinner v. Oklahoma, and as Justice Field did in Ho Ah Kow. ${ }^{562}$ And courts should assess whether reasonable accommodations are possible, if not required, as is done in cases arising under the Americans with Disabilities Act ${ }^{563}$ and Title VII of the Civil Rights Act of 1964. ${ }^{564}$ In contrast, the Sherbert-Yoder test simply required the government to pursue its interest using the least restrictive means. Thus, the Sherbert-Yoder test would have wrongly allowed a law to stand that discriminated on the basis of religion if that law served an important government interest, even if it did not promote the general good of the whole people. And the Sherbert-Yoder test would also wrongly permit a law to stand that inflicts substantial, irreparable

\footnotetext{
${ }^{562}$ See Ho Ah Kow, 12 F. Cas. at 253-254 (balancing the benefits of the head shaving ordinance against the severe, negative impact on Chinese religious practices)

${ }_{563}^{5}$ See 42 U.S.C. $\$ \S 12101-12117,12201-12213$ (1994).

${ }^{564}$ See 42 U.S.C. $\$ 2000 \mathrm{e}(\mathrm{j})$.
} 
harm on a religious group, so long as the law in question does so using the least restrictive means.

Perhaps for these reasons the Sherbert-Yoder balancing test turned out to provide a pretty skimpy protection for freedom of religion even in the days between 1963 and 1990 when the test was widely used. Professor Adam Winkler points out that under the Sherbert-Yoder balancing test and under RFRA, seventy-two percent of all the laws that have been challenged have been upheld, even though the courts reviewing those laws were supposed to be applying strict scrutiny. ${ }^{565}$ In contrast, in other areas of constitutional law where strict scrutiny is used, only thirty percent of the cases that get strict scrutiny resulted in the courts upholding the law being challenged. ${ }^{566}$ For this reason, some referred to the Supreme Court's opinion in Smith as a “mercy killing” because the Sherbert-Yoder balancing test had proved to be such an ineffective protection for the free exercise of religion. ${ }^{567}$

The laws that were struck down as unconstitutional in both Sherbert and Yoder may very well have been consistent with the original meaning of the Free Exercise Clause itself. Denying welfare benefits or access to private charity schools may very well "abridge" the Free Exercise of Religion, but they do not "prohibit" it. The verb "prohibit" implies a government action that is backed up with criminal sanctions. It is completely implausible to say that a denial of welfare benefits is a "prohibition" on the free exercise of religion. A criminal truancy statute in the

\footnotetext{
${ }^{565}$ See Winkler, supra note 452, at 860. Professor Winkler cites a similar study by James Ryan from the 1980s showing an astounding eighty-seven percent survival rate. See Id. (citing James E. Ryan, Note, Smith and the Religious Freedom Restoration Act: An Iconoclastic Assessment, 78 Va. L. Rev. 1407 (1992)). Winkler also explains that claims for exemptions from generally applicable laws are rejected $74 \%$ of the time, and claims that laws intentionally target religious practices are successful $100 \%$ of the time. Winkler, supra note 452 , at 860-861.

${ }^{566} I d$. at 796.

${ }^{567} I d$. at 859 (citations omitted).
} 
context of Yoder might well rise to the level of being a "prohibition," but the denial of welfare benefits in Sherbert and in Thomas v. Review Board do not. ${ }^{568}$

The government's actions in Sherbert, in Yoder, and in Thomas v. Review Board all, however, do violate the anti-discrimination command of the Fourteenth Amendment. The laws in all three of these cases clearly discriminated on the basis of religion. The law in Sherbert denied a Seventh Day Adventist Sabbath observer unemployment benefits when she was fired because, under her religion, the Sabbath was celebrated on Saturdays, and she refused to work on that day. But for her religion, the plaintiff would not have been fired and would not have needed unemployment benefits. The law in Yoder, like the law in Society of Sisters, placed a substantial and irreparable harm on the parents of school children - in this case on the Amish. The Wisconsin legislature was probably genuinely concerned with the level of education that school children were receiving, but the Amish had a different approach to education based on their own religious values, which they ought to have been free to pursue. The Wisconsin law in Yoder was, in effect, a form of discrimination on the basis of religion, which was barred by the Fourteenth Amendment. The law in Thomas v. Review Board denied unemployment benefits to a Jehovah's Witness who refused to work for an employer who made military equipment. Here too, the law in question operated as a form of discrimination on the basis of religion

The basic problem in all of these cases is that the religious individuals who brought them were not similarly situated to secular individuals. The Seventh Day Adventist in Sherbert celebrated the Sabbath on Saturdays and not on Sundays. The Amish parents and child in Yoder thought that education mandated after eighth grade was bad for the soul. And, the Jehovah's Witness in Thomas v. Review Board thought that it would violate his religion for him to work for an employer who made military equipment. In all three cases, religious citizens were treated as if

\footnotetext{
${ }^{568}$ Thomas v. Review Board, 450 U.S. 707.
} 
they were identical to secular citizens when in reality they were not alike. Fourteenth Amendment principles are violated, not only when we treat two similar people differently, but also when we treat two people who are in reality different in the same way. Sherbert, Yoder, and Thomas are thus not examples of Griggs v. Duke Power disparate impact analysis run amok. They are instead a reminder that we may sometimes need to treat different people differently if we want to secure them a truly equal citizenship under the law.

For this reason, the foundational religious liberty case of all time, Pierce v. Society of Sisters was correct because it involved an instance of discrimination on the basis of religion. In Pierce v. Society of Sisters, the facially neutral law in question applied much more harshly to religious families who wanted, as a matter of their faith, to send their children to private religious schools than it did to secular families. Even though there might be a public purpose served by requiring all children to attend public schools, the law would fail strict scrutiny equal protection analysis because it was partially aimed at closing down private religious schools, and it was not a general law enacted for the good of the whole people. ${ }^{569}$ Religious education is a critical part of a religious child's upbringing, and forcing a child to attend a secular public school in which the child is taught in a secular way is clearly an irreparable harm that could be easily avoided with a religious exemption. The fact that religious education is not a critical part of a secular child's upbringing does not mean that religious education can just be outlawed across the board. Religious children and secular children simply have different educational preferences. Treating both groups the same way when they are in fact different violates the Fourteenth Amendment.

Finally, we think, as we implied above, that the decision in Smith was inconsistent with the Fourteenth Amendment. The law in Smith penalizing ingestion of peyote in a Native

\footnotetext{
${ }^{569}$ See Society of Sisters, 296 F. at 936-937 (D. Or. 1924) aff'd $d_{2} 268$ U.S. 510 (1925) (discussing how the purpose of the Oregon law was to target parochial and private schools).
} 
American religious ceremony should have been struck down since it directly burdened the exercise of religion in a ceremony of worship and posed no harm to other individuals. The harm to the Native Americans involved in this case was certainly substantial and irreparable with potentially far-reaching consequences. Although the drug laws do address a huge societal problem - one which likely can only be addressed by government - allowing carve outs for a few religious rituals would not undermine the efficacy of those laws. ${ }^{570}$ A narrow exemption for a legitimate religious practice should have been feasible. In Hosanna-Tabor, the Supreme Court appeared to partially pare back Smith, by creating a significant, yet ambiguous exception to Smith's general rule. ${ }^{571}$ In future cases, the Supreme Court should invoke the Fourteenth Amendment's ban on discrimination on the basis of religion as Justice Scalia would have done in his dissent in Locke v. Davey. This would allow the Court to avoid the Smith rule entirely without directly overruling a landmark precedent that it has relied upon for over twenty years.

\section{B. Establishment Clause}

\section{Originalism and the Establishment Clause}

As an original matter, the Establishment Clause created only the most minimal limits on government. ${ }^{572}$ Prior to the Fourteenth Amendment, the Establishment Clause only applied to the federal government and not to the states. At the federal level, the Clause substantively guaranteed disestablishment. But beyond that, the Clause served simply as a structural tool of federalism, permitting the states to choose whether to have religious establishments or not and barring the

\footnotetext{
${ }^{570}$ See Gonzalez v. Raich, 545 U.S. 1, 39-41 (2004) (Scalia, J., concurring) (arguing that allowing an exemption to federal drug laws for medicinal users of marijuana would undermine a national scheme to fight drug abuse).

${ }^{571}$ Michael W. McConnell, Reflections on Hosanna-Tabor, 35 Harv. J.L. \& Pub. Pol'y 821 (2012)

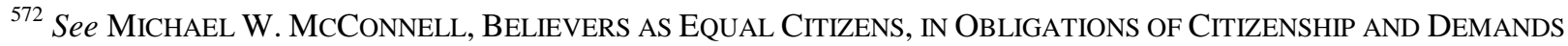
OF FAITH: RELIGIOUS ACCOMMODATION IN PluRAlist DEMOCRACIES 90, 100 (Nancy L. Rosenblum ed., 2000) [hereinafter "BELIEVERS AS EQUAL CITIZENS "] (describing how the Establishment Clause set up a "pluralist state" as opposed to a "secular state")
} 
federal government from having any say over this matter. ${ }^{573}$ Whether the Fourteenth Amendment incorporated the Establishment Clause to apply against the states has been the subject of debate among originalists with some arguing against incorporation ${ }^{574}$ and some arguing in favor of it. ${ }^{575}$ The evidence seems to us to more likely favor the incorporation argument. By 1868, twenty seven out of thirty seven state constitutions had some form of an establishment clause. ${ }^{576}$ This suggests that freedom from an established state church is a right that was deeply rooted in American history and tradition in 1868 when the Fourteenth Amendment was adopted.

The Establishment Clause prohibits laws that "substantively institute, authorize, or otherwise establish religion," as Professor Douglass Laycock has written. ${ }^{577}$ The Clause does not set up a wall of separation between church and state. ${ }^{578}$ As Professor Michael Paulsen has argued, the Establishment Clause should be interpreted using an equal protection approach. ${ }^{579}$ In

\footnotetext{
${ }^{573}$ See AkHil Reed Amar, The Bill of Rights: Creation and Reconstruction 32-41 (1998); Kurt T. Lash, The Second Adoption of the Establishment Clause: The Rise of the Nonestablishment Principle, 27 Ariz. St. L.J.1085, 1089-99 (1995); Michael W. McConnell, Establishment and Disestablishment at the Founding, Part I:

Establishment of Religion, 44 Wm. \& Mary L. Rev. 2105, 2109 (2003); Joseph M. Snee, Religious Disestablishment and the Fourteenth Amendment, 1954 Wash. U. L.Q. 371, 406-07; Paulsen, Supra note 16, at 317; William C. Porth \& Robert P. George, Trimming the Ivy: A Bicentennial Re-Examination of the Establishment Clause, $90 \mathrm{~W}$. Va. L. Rev. 109, 136-39 (1987); Daniel O. Conkle, Toward a General Theory of the Establishment Clause, 82 Nw. U. L. Rev. 1113, 1132-35 (1988); William K. Lietzau, Rediscovering the Establishment Clause: Federalism and the Rollback of Incorporation, 39 DePaul L. Rev. 1191, 1201 (1990). Even Lawrence Tribe concedes that the primary purpose of the clause was "to protect state religious establishments from national displacement." LAURENCE H. TRIBE, AMERICAN CONSTITUTIONAL LAW §14-3, at 1161 (2d ed. 1988). James Madison tried to create a national establishment clause that would restrict the states as well, but the effort was ultimately rejected. See 1 ANNALS OF CONG. 420, at 758 (Gales \& Seaton eds.1789).

${ }^{574}$ See, e.g., Lietzau, supra note 573, at 1210 ("While many specific Bill of Rights incorporations have been criticized, none are so thoroughly contradicted by the historically discernible intentions of our forefathers than that of the establishment clause."); Paulsen, supra note 16, at 314 ("The Supreme Court's reading of the religion clauses is completely indefensible-historically, textually, and practically."); see also Zelman, 536 U.S., at 678 (Thomas, J., concurring) (same). The basic argument is that the Establishment Clause was designed primarily (or perhaps solely) to delineate federal power, barring Congress from interfering with states' establishments. See Lietzau, supra note 573, at 1199. It is therefore incoherent to expand a principle of federalist structure to the states. See Id. at 1207-1208. ${ }^{575}$ Phillip Hamburger argues that the Establishment Clause had a substantive element and was incorporated via the Fourteenth Amendment. See Philip Hamburger, Separation and Interpretation, 18 J.L. \& Pol. 7, 60-61 n.84 (2002); Hamburger, supra note 18, at 60-61, 106 n.40.

${ }^{576}$ See Calabresi \& Agudo, supra note 37, at 31.

${ }^{577}$ Douglas Laycock, The Many Meanings of Separation, 70 U. Chi. L. Rev. 1667, 1671-72 (2003).

${ }^{578}$ See Philip Hamburger, SePARATION OF ChURCh AND STATE, Supra note

${ }^{579}$ Paulsen, supra note 16.
} 
1786, Samuel Johnson defined the word "establishment" as mainly having financial connotations, as in a "settlement, fixed rate" or an "allowance, income, salary." ${ }^{580}$ Samuel Johnson also defined "establishment" as being a "foundation, fundamental principle" or a "confirmation of something." 581 Samuel Johnson defined the verb form "to establish," as meaning "to settle firmly, fix unalterably," "to make firm, to ratify," "to fix or settle in an opinion," "to found, to build firmly, fix immoveably." 582 Johnson's definitions thus would seem to support Laycock's assertion that an establishment was a substantial undertaking. Samuel Johnson also defines the verb "establish" as "to settle in any privilege or possession." 583 This definition suggests that the Framers may have included the Establishment Clause in the First Amendment to prevent Congress from forming a national monopoly religion by granting a special privilege to one religion but not to others. Read this way, the Establishment Clause represents a ban on a certain form of particularly obnoxious class legislation.

Professor McConnell argues that six categories of laws fall within the original Eighteenth Century understanding of what constitutes an establishment of religion. These six categories include laws that: “(1) control ... doctrine, governance, and personnel of the church; (2) [make] compulsory church attendance; (3) [give a religion] financial support; (4) prohibit... worship in dissenting churches; (5) [govern the] use of church institutions for public functions; and (6) restrict... political participation to members of the established church." ${ }^{584}$ McConnell's bright line categories effectively ask whether a particular law actively establishes religion. ${ }^{585}$

\footnotetext{
${ }^{580}$ See SAMUEL JOHNSON's 1786, supra note 512.

${ }^{581} \mathrm{Id}$.

${ }^{582} \mathrm{Id}$.

${ }^{583} \mathrm{Id}$.

${ }^{584}$ McConnell, supra note 525, at 2131.

585 The modern Supreme Court's tests for evaluating Establishment Clause cases are generally inconsistent with the Clause's original meaning. For instance, the court in Lemon v. Kurtzman established a three part test to evaluate facially neutral laws: 1) "the statute must have a secular legislative purpose;" 2) the statute's "principal or primary effect must be one that neither advances nor inhibits religion;" and, 3) "the statute must not foster an excessive
} 
McConnell avoids such nebulous concepts as whether a law "advances religion," whether it has a "secular legislative purpose," whether it "endorses religion," whether it leads to "entanglement," or whether it respects the "separation of church and state"

The Establishment Clause on its face seems only to bar actions taken by Congress, and not actions taken by the executive or the judicial branches of government. ${ }^{586}$ This point flows from the constitutional text which states that "Congress shall make no law respecting an establishment of religion." ${ }^{, 587}$ But actions taken by the President alone or by other executive branch or judicial officials do not violate the clause. The point is that making an establishment of religion is a major undertaking that can only be accomplished with the participation of multiple branches of government, as is required for Congress to make a law. Accordingly, the President's declaration of a day of prayer and Thanksgiving, his appointment of military chaplains, or the placement of religious symbols in the Oval Office or on the walls of the Supreme Court building plainly do not violate the text of the Establishment Clause. The text also seems to permit placing

government entanglement with religion." 403 U.S. 602, 612-13 (1971). These factors really have nothing to do with establishing a religion as was understood at the time of the founding. In Agostino v. Felton, the Supreme Court appeared to modify the Lemon test. There, the Court said that in evaluating aid to religion, courts should ask whether the government had a permissible non-sectarian purpose and whether the law had a non-religious primary effect. 521 U.S. 203, 234 (1997) To determine whether an effect was permissible or non-permissible, a court should evaluate three factors: (1) whether the aid supported religious "indoctrination;" (2) whether recipients of the aid were defined by a reference to religion; and (3) whether the aid program caused an excessive entanglement with religion. 521 U.S. 203, 234 (1997). Again, these factors are almost entirely irrelevant as an original matter. Unsurprisingly, using these factors has led to decisions that diminish religious liberty, instead of promoting it. For instance, in Estate of Thornton v. Caldor, Inc., the Court struck down a law requiring employers to allow their employees to take off work on the Sabbath. 472 U.S. 703 (1985) The court explained that the law had the primary effect of advancing religion because it increased costs for employers and co-workers to accommodate the employee's religious practice. $\underline{I d}$. The repression of religious liberty in Thornton cannot be underemphasized. See also Board of Education of Kiryas Joel Village School District v. Grumet, 512 U.S. 687 (1994) (striking down a law creating a separate school district for a group of Chassidic Jews who were unable to benefit from the secular public school system).

${ }^{586}$ See Hamburger, supra note 575, at 52.

${ }^{587}$ U.S. CONST. amend. I $§ 1$ (emphasis added). 
religious symbols anywhere on government buildings or in parks, even in courtrooms, as well as using the phrase "In God We Trust" as our national motto. ${ }^{588}$

\section{Establishment Clause Questions after the Fourteenth Amendment}

Christopher Eisgruber \& Lawrence Sager argue that Establishment Clause cases should be viewed from what they consider to be an equality perspective. ${ }^{589}$ They believe that the Establishment Clause's equality principle requires a hermetically strict separation of church and state. Essentially, they think that almost any partiality that the government might show towards religion violates an equality principle. They thus conclude that religious exemptions, displays of religious symbols, and vouchers for school children are all unconstitutional.

A wooden, textual reading of the Fourteenth Amendment analysis could in theory lead to a strict wall of separation between church and state, particularly if one starts from the assumption that religion plays and should play no role in people's lives. If the Fourteenth Amendment bans class legislation, one could thus argue that the government should not be able to provide religion with special benefits not offered to the general population. A religious display during the holiday season could thus be construed a special privilege, allowing a particular religion to advertise itself or convey a message. And religious exemptions in general could be argued to be classic

\footnotetext{
${ }^{588}$ The clause's emphasis on congressional actions also answers complaints that the participation of clergy members and churches in politics is an establishment of religion. The language solely restricts Congress from passing a law and in no way burdens religious individuals or organizations from involving themselves in politics. See Hamburger, supra note 575, at 52. This is sensible because the purpose of the clause was to protect individual religious freedom. See Hamburger, supra note 18, at 101. Barring religious individuals or organizations from politics also should violate the No Religious Test Clause.

${ }^{589}$ See, e.g., Christopher L. Eisgruber \& Lawrence G. Sager, Why the Religious Freedom Restoration Act Is Unconstitutional, 69 N.Y.U. L. Rev. 437, 441 (1994) (The "equal regard" principle requires "that government treat the deep, religiously inspired concerns of minority religious believers with the same regard as that enjoyed by the deep concerns of citizens generally. This principle takes stark inequalities of treatment as a sufficient ground for constitutional solicitude, and it applies to inequalities that burden non-believers as well as to those that target religion.”); see also Gellman \& Looper-Friedman, supra note 18 (arguing that religious displays violate the Equal Protection Clause because they make non-believers feel marginalized).
} 
examples of special class laws that carve out a unique benefit for a single class of individuals and hold the rest of the population to a different standard. It is for this reason in City of Boerne v. Flores that Justice Stevens concluded that the Religious Freedom Restoration Act was an unconstitutional establishment of religion over irreligion. ${ }^{590}$

The proper response to Justice Stevens and Professors Sager and Eisgruber requires that we recall that a critical feature of lawsuits challenging partial or special laws during the Antebellum Jacksonian period was that plaintiffs could only bring law suits when they had suffered actual economic damages from a law. ${ }^{591}$ Litigation challenging special or partial class based laws was not initiated by average citizens under a theory that those laws caused emotional distress. Instead the plaintiffs who challenged class legislation during the Jacksonian era were always attempting to recover a tangible economic loss that had resulted from the law they were challenging. ${ }^{592}$ For this reason, there really was no difference between special laws, which convey a unique privilege, and special laws, which impose a unique burden, because both types of laws are economically burdensome. Thus, a standing requirement that a litigant have suffered actual and concrete legal injury was essentially built into all the pre-1868 class legislation cases. No one could have challenged as class legislation a law that caused them to suffer emotional distress unless they had also suffered real and actual economic damages.

\footnotetext{
${ }^{590}$ City of Boerne v. Flores, 521 U.S. at 536 (Stevens, J., concurring)

${ }^{591}$ See Saunders, supra note 19, at 299, n.243 (noting that "none of the antebellum cases contain any suggestion that discriminatory intent, standing alone - that is, without discriminatory effect - would raise constitutional concerns").

592 See, e.g., Reed v. Wright, 2 Greene 15, 27-28 (Iowa 1849) (a half-breed Indian challenged a law singling out halfbreed Indians for special disadvantage as land owners and attempting to recover property); Lewis $v$. Webb, $3 \mathrm{Me}$. 326 (1825) (adversely affected party challenging a law granting certain person a special right to appeal financial obligations between adverse parties); Budd v. State, 22 Tenn. (3 Hum.) 483 (1842) (criminal defendant challenged a special criminal law applicable only to employees of a certain bank); Jones' Heirs v. Perry, 18 Tenn. (10 Yer.) 59 (1836) (heirs of an estate challenged a law granting a guardian of certain minors a special right to sell their property); Officer v. Young, 13 Tenn. (5 Yer.) 320 (1833) (defendant challenged a law granting a certain person a special right to prosecute an appeal in the name of a deceased person); Ward v. Barnard, 1 Aik. 121 (Vt. 1825) (a creditor challenged a law granting a debtor a special right to release from debtor's jail without paying back his debt); Saunders, supra note 19, at 252, n.28.
} 
There is no reason whatsoever to think that the Fourteenth Amendment's ban on class legislation overrode this standing requirement for challenges to class-based laws, and there is no historical evidence that the Fourteenth Amendment created a cause of action for unharmed citizens. In an Establishment Clause context, to the extent that a law creates a unique privilege or burden and causes actual economic damage, it constitutes class legislation, just as it would in any other context. But absent actual economic damages, a law is simply not class legislation in the sense in which that term would have been understood in 1868. Therefore the Supreme Court's recent move toward tightening up the standing requirements in Establishment Clause cases is completely consistent with the Fourteenth Amendment's ban on class legislation. ${ }^{593}$

Sager and Eisgruber's belief that some abstract notion of equality requires courts to strike down almost any relationship between government and religion is wrong for multiple reasons. As we just explained, their argument has no basis in the Fourteenth Amendment's ban on class legislation, which contained a standing requirement and never recognized the causes of action that Sager and Eisgruber endorse. Religious displays, President Obama's annual Easter prayer breakfast, and the Supreme Court's recent Christmas Party simply do not constitute class legislation because no one is legally injured by any of those government actions. Second, Sager and Eisgruber's argument is irreconcilable with the original meaning of the Establishment Clause which required an actual establishment of religion, as Professors Laycock and McConnell have explained. Mere whiffs of religion are not to be mistaken for an establishment like the one that existed in England from 1607 to $1791 .{ }^{594}$ The idea that a religious display constitutes an

\footnotetext{
${ }^{593}$ See Arizona Christian Sch. Tuition Org. v. Winn, 131 S. Ct. 1436, (2011) (restricting the application of Flast v. Cohen, 392 U.S. 83 (1968), which served as an exception to standing requirements in Establishment Clause cases); Hein v. Freedom From Religion Foundation, 551 U.S. 587 (2007) (refusing to apply Flast); Valley Forge Christian College v. Americans United for Separation of Church and State, 454 U.S. 464 (1982) (same).

${ }^{594}$ See supra p.112-115.
} 
establishment of religion because some peoples' consciences are offended by it is frankly laughable. Many people's consciences are offended by the teaching of Darwin in public and private schools. That does not mean that they have suffered a legal injury entitling them to sue.

And third, using the Fourteenth Amendment or First Amendment as a sword, rather than a shield, to lash out at religion is bizarre given that those amendments were designed in part to guard and promote religious liberty. ${ }^{595}$ It would be repressive and not freedom-enhancing for a court to strike down religious exemptions designed to protect religious adherents damaged by a generally applicable law. For that reason, it would be repressive and not freedom-enhancing to refuse to grant vouchers to religious children who want to attend private religious schools or to refuse to provide vouchers for religious schools, even though vouchers are provided for private secular schools. Such refusals do not represent equality. They represent discrimination. And banning religious displays that people want and enjoy when those displays do not economically damage anyone is a restriction on religious freedom, not a promotion of it. Sager and Eisgruber's "equal regard" principle is simply not consistent with either the original meaning of either the Fourteenth or the First Amendment, and it violates basic principles of liberty and equality. In reality Sager and Eisgruber are promoting a secular state that is more in line with the traditions of France than it is in line with those of the United States. ${ }^{596}$

\section{Voucher programs do not violate the Establishment Clause}

Government programs that provide tuition vouchers for students attending the private school of their choice, including private religious schools, do not violate the Establishment Clause or the Fourteenth Amendment. In Zelman v. Simmons, the Supreme Court held that such

\footnotetext{
595 See BElieVERS AS EQUAL CITIZENS, supra note 524, at 104-105.

${ }^{596}$ See Fr. CONST. Title 0, art. 1 ("France is an indivisible, secular, democratic and social Republic.")
} 
vouchers do not violate the Establishment Clause. ${ }^{597}$ Voucher programs for the use of private schools do not constitute class legislation because they are general welfare benefits available to all residents, and they do not single out a class of people for unique benefits or burdens. Because students can use their education vouchers equally at both religious and at secular schools, voucher programs are really no different from general welfare payments which recipients can spend either on secular or religious goods and services. Suits challenging voucher programs should probably even be dismissed for lack of standing, ${ }^{598}$ as the Supreme Court held in Arizona Christian School Tuition Organization v. Winn. ${ }^{599}$

School vouchers do not offend any of Professor McConnell's six categories of laws prohibited by the Establishment Clause. ${ }^{600}$ Perhaps one could argue that vouchers provide financial support for religious institutions. But the kinds of financial support that are barred by the Establishment Clause are those instances where the government directly funds religion by paying the salary of clergy or providing for the upkeep of churches or synagogues. In contrast, vouchers for education give every student and parent the right to choose whether to use government money at a private school, be it secular or religious, instead of having to attend a secular public school. It would truly be a distortion of the Constitution to use the Establishment Clause, which guaranteed religious liberty, and the Fourteenth Amendment, which guaranteed individual liberty, to strike down a program that actually enhances individual educational choice.

The history of the Blaine Amendment also indicates that vouchers do not violate the Establishment Clause. In 1875, James G. Blaine, who was at that point a Congressman from Maine, proposed an amendment to the federal Constitution banning state governments from

\footnotetext{
597536 U.S. 639 (2002).

${ }^{598}$ See Schlesinger v Reservists, 418 U.S. 208 (1974) (denying relief for a general citizens suit).

599131 U.S. 1436 (2011).

${ }^{600}$ See supra p.114.
} 
funding religious schools and institutions. ${ }^{601}$ Although the Senate did not ratify the Blaine Amendment, thirty nine states and the District of Columbia eventually passed similar provisions over a period of time that stretched from 1848 to 1959. The fact that Congress and the States felt the need to pass the Blaine Amendment in 1875 to stop government money from going to religious schools and institutions itself shows that members of Congress in 1875 did not think that the Establishment Clause alone barred government funding of religious schools and institutions. If the Establishment Clause had already banned public funds from reaching religious institutions, then the Blaine Amendment would have been unnecessary. There is little historical evidence that members of Congress objected to the Blaine Amendment on the grounds that the Establishment Clause already did what the Blaine Amendment was supposed to do. ${ }^{602}$ Rather, the history supports the Supreme Court's holding in Zelman.

One counterargument is that in 1875 many members of Congress may not have believed that the Bill of Rights and therefore the Establishment Clause applied to the states. Accordingly, they may have simply wanted to restrict the states in the same way that the federal government was restricted. This explanation seems sensible in the wake of the Slaughter-House Cases, in which the Supreme Court implicitly ruled that the Bill of Rights did not apply to the states. ${ }^{603}$ It is also supported by statements made by members of Congress during the Blaine Amendment debate in 1875 and $1876 .{ }^{604}$ But it is contradicted by the fact that Congress felt the need to add a

\footnotetext{
${ }^{601}$ See Blaine Amendment Reconsidered, supra note 388, at 49-50 (citing The Index, Dec. 2, 1875, at 570): No State shall make any law respecting an establishment of religion, or prohibiting the free exercise thereof; and no money raised by taxation in any State for the support of public schools, or derived from any public fund therefor, nor any public lands devoted thereto, shall ever be under the control of any religious sect; nor shall any money so raised or lands so devoted be divided between religious sects or denominations.

${ }^{602}$ See Blaine Amendment Reconsidered, supra note 388, at 38.

${ }^{603}$ Slaughter-House Cases, 83 U.S. 36.

${ }^{604}$ Blaine Amendment Reconsidered, supra note 388, at 62-64.
} 
Blaine-style provision to the D.C. Code, banning government funds to religious organizations in the District of Columbia and restricting U.S. Government expenditures in general. ${ }^{605}$ That provision would have been unnecessary if the Establishment Clause already barred public funds from reaching religious schools and organizations. And the discussion about incorporation was limited during the congressional debate, and there is little evidence that more than a handful of congressional members were concerned with the issue of incorporation. ${ }^{606}$ Rather, the focus of the debate was on the substantive merits of the Blaine Amendment. ${ }^{607}$

\section{The Blaine Amendments}

Blaine Amendments play a significant role in the story of religion and the Fourteenth Amendment. We think that the various Blaine Amendments in thirty-seven states and in the District of Columbia violate the Fourteenth Amendment's ban on class legislation because they facially discriminate against religion, and they are not general laws that promote the good of the whole people. These Amendments, which were passed at the end of the Nineteenth and the beginning of the Twentieth Centuries, were motivated by anti-Catholic bigotry and to a lesser extent by hatred of other minority religions. That ugly history has been to some extent forgotten in the modern secular era, where Blaine Amendments are currently viewed as being general antireligion clauses, and not as being clauses that target Catholics or another specific group. Blaine Amendments are a reminder of how insidious a neutral, generally applicable law that purports to only burden religion in general can be. Blaine Amendments have also received some cover in the modern era from the Court's Free Exercise Clause case law because they do not on their face target a specific religion, such as Catholicism, and instead discriminate against all religions equally. We think that under a Fourteenth Amendment anti-discrimination analysis, Blaine

\footnotetext{
${ }^{605}$ See D.C. CODE 44-715 (1896).

${ }^{606}$ Blaine Amendment Reconsidered, Supra note 388, at 63-64.

${ }^{607} \mathrm{Id}$.
} 
Amendments should surely be struck down. Laws that barred government funds from going to organizations or schools run by racial minorities - say, historically black colleges -- would surely violate the Fourteenth Amendment. We find it impossible to see why blocking government funds from going to religious schools and organizations should be any different. Blaine Amendments discriminate on the basis of religion in distributing government money, and they should thus be subjected to strict scrutiny and struck down.

The passage of the various Blaine Amendments in the Nineteenth Century, both before and after the Fourteenth Amendment was ratified in 1868, does make one wonder whether the original public meaning of the Fourteenth Amendment's anti-discrimination command really did ban discrimination on the basis of religion. This question may be of interest to those who are original intent theorists, but it is irrelevant to those who believe in the original public meaning of the constitutional text. The objective original public meaning of the Fourteenth Amendment as it was adopted in 1868 banned all forms of class legislation including class legislation targeted at religion. The fact that some framers or other politicians subjectively believed or expected that religion would not be included in this ban is quite simply irrelevant to determining the objective public meaning of the constitutional text. Thus the Nineteenth Century practice of discriminating on the basis of religion, just like the Nineteenth Century practice of discriminating on the basis of race, became unconstitutional on the day the Fourteenth Amendment was ratified. Practice is an imperfect guide in discerning the original public meaning of constitutional texts.

\section{A. The History of the Blaine Amendments}

As we mentioned above, there are currently thirty-seven states with so-called "Blaine Amendments" in their state constitutions that prohibit government funds from reaching religious 
organizations, such as schools. ${ }^{608}$ The District of Columbia has a comparable provision in the D.C. Code. ${ }^{609}$ These Blaine Amendments come in varying forms, and state courts have used them to strike down many different kinds of government funding schemes. ${ }^{610}$ A typical provision reads, "no public money or property shall ever be appropriated, applied, donated, or used, directly or indirectly, for the use, benefit, or support of any sect, church, denomination, or system of religion, or for the use, benefit, or support of any priest, preacher, minister, or other religious teacher or dignitary, or sectarian institution as such." ${ }^{\prime 11}$ The bigoted and shameful history of Blaine Amendments has been well-documented ${ }^{612}$ and is worth briefly recounting.

Conflict over funding religion began with the advent of the public schools in the $1830 \mathrm{~s}$ and 1840s. Public schools during this time characteristically taught the Bible from a Protestant perspective and imbued Protestant values in children. At the same time, large numbers of Catholics, and to a lesser extent Jews, began immigrating to the United States. ${ }^{613}$ The public education of children in an increasingly pluralistic religious environment led to conflicts among religious factions with deeply held religious values. The Protestant majority set up a public school curriculum designed to convey Protestant values, and many dissenting Catholics and Jews

${ }^{608}$ Duncan, supra note 5.

${ }^{609}$ D.C. CODE $§ 44-715$ (2012).

${ }^{610}$ See Frank R. Kemerer, State Constitutions and School Vouchers, 120 Educ. L. Rep. 1 (1997) (discussing the various State Blaine Amendments and categorizing them according to levels of restrictiveness); Toby J. Heytens, Comment, School Choice and State Constitutions, 86 Va. L. Rev. 117, 128-131 (2000) (discussing different state court decisions).

${ }^{611}$ OKLA. CONST. art. II, § 5 (1910).

${ }^{612}$ See generally Blaine Amendment Reconsidered, supra note 388, at 38.

${ }^{613}$ At the time of the Revolution, Catholics comprised only $1 \%$ of the population, but grew to $3.3 \%$ by $1840,10 \%$ by 1866 , and $12.9 \%$ by 1891 . Duncan, Supra note 5 , at $504 .{ }^{613}$ The Jewish population followed a similar trend, growing from 2,500 in 1800 to 15,000 in 1840 to $125,000-200,000$ in 1860 and approximately 1 million in 1900 . LIBRARY OF CONGRESS, http://www.loc.gov/exhibits/haventohome/timeline/haven-timeline_2.html (last visited March 17, 2011). From 1845 to 1850 alone, one million Irish immigrants came to this country. See Meir Katz, The State of Blaine: A Closer Look at the Blaine Amendments and Their Modern Application, Beckett Fund (June 2011) available at http://www.fed-soc.org/doclib/20110603_KatzEngage12.1.pdf. 
understandably resisted. ${ }^{614}$ But Protestant educators went a step farther and used public schools as a forum for denigrating Catholics and excluding non-majoritarian religious views. ${ }^{615}$ In an attempt to level the playing field, Catholics began requesting private school funding in such major cities as New York, Philadelphia, Boston, and Baltimore. ${ }^{616}$

Protestants responded to these requests for government funding of parochial schools with a strong legislative backlash designed to prevent Catholics from ever controlling public schools or from ever receiving any public funds. In 1842, the New York State legislature passed a law that banned government money from ever going to any schools where "any religious sectarian doctrine or tenet shall be taught, inculcated, or practiced. ${ }^{617}$ In 1848 , Wisconsin became the first state to amend its State constitution to impose a similar prohibition on government money ever going to a religious school. ${ }^{618}$ By 1875 , another thirteen states had followed Wisconsin's lead by

\footnotetext{
${ }^{614}$ See Steven K. Green, The Insignificance of the Blaine Amendment, 2008 B.Y.U. L. Rev. 295, 304 [hereinafter "Insignificance of the Blaine Amendment".

${ }^{615}$ See, e.g., Hamburger, supra note 18, at 220 (noting how public schools in New York City "required children to read the King James Bible and to use textbooks in which Catholics were condemned as deceitful, bigoted, and intolerant"); id. at $223 \mathrm{n} .83$ (citing the report of a special school committee that New York City public schools that "the books used in the public schools contain passages that are calculated to prejudice the minds of children against the Catholic faith"); see also John C. Jeffries, Jr. \& James E. Ryan, A Political History of the Establishment Clause, 100 Mich. L. Rev. 279, 300 (2001) (discussing the controversial practice of reading the Bible without interpretation); Joseph P. Viteritti, Blaine's Wake: School Choice, the First Amendment, and State Constitutional Law, 21 HARV. J.L. \& PUB. POL'Y 657, 666 (1998) (observing that, while "[t]he American common school was founded on the pretense that religion has no legitimate place in public education... [i]n reality it was a particular kind of religion that its proponents sought to isolate from public support").

${ }^{616}$ See Diane Ravitch, ThE GREAT School WARS: NEW York CITY, 1805-1973, 3-76 (1974); Joseph P. Viteritti, Choosing Equality: Religious Freedom and Educational Opportunity Under Constitutional Federalism, 15 Yale L. \& Pol'y Rev. 113, 192 (1996).

${ }^{617}$ See Jeffries \& Ryan, supra note 615, at 301; Joseph Viteritti cites the law as New York law as 1844 N.Y. LAWS ch. 320, § 12. See Viteritti, supra note 616, at 146 n.176.

${ }^{618}$ WIS. CONST. art. I, $\S 18$ (added 1848) ("nor shall any money be drawn from the treasury for the benefit of religious societies, or religious or theological seminaries.”)
} 
adopting similar Blaine Amendments to their State constitutions. ${ }^{619}$ Although on their face these prohibitions appeared to neutrally prohibit all government funding of religious schools, protestant religious practice in the public schools was so common during this time period that it was clear that these states were not endorsing secularism in any way. ${ }^{620}$ Several State constitutions adopted during this period expressly used the word "sectarian," which, in the Nineteenth Century, was taken to be a code word for "Catholic." 621

At the national level, politicians jumped on the anti-Catholic bandwagon. The "KnowNothings," later known as the American Party, were dedicated to "remov[ing] all foreigners, aliens, or Roman Catholics from office" and opposed appointing Catholics to positions of power. ${ }^{622}$ The Know-Nothings and the American Party had enormous success in local and national elections. ${ }^{623}$

Opposition to funding private religious schools was based primarily on a fear and hatred of Catholics and immigrants. Protestant fear of Catholics was partly motivated by the belief that Catholic doctrines were contrary to American principles of freedom, individuality, and perhaps democracy. For instance, the Catholic Church's traditionally authoritarian structure, close connection between church and state, and tight regulation of individual rights and conduct was perceived as somewhat un-American. ${ }^{624}$ Opposition to funding religious schools was also

\footnotetext{
${ }^{619}$ MiCH. CONST. art. IV, § 40 (1850); IND. CONST. art I, § 6 (added 1851); OHIO ConST. art. VI, § 2 (added 1851); MASS. CONST. art. XVIII (added 1855); MINN. CONST. art. XIII, § 2. (1857); OR. ConST. art. I, § 5 (1857); KAN. Const. art. VI, $\S 8$ (1859); KAN. CONST. art. VI, § 6; Miss. Const. art. IV, § 9 (1868); Ill. Const. art. VIII, § 3 (1870); Ala. Const. art. XII, § 8 (1875); PA. Const. art. III, § 18 (1874); Mo. ConST. art. XI, § 11 (1875); NEB. CONST. art. VIII, $\S 11(1875)$.

${ }^{620}$ See Jeffries \& Ryan, supra note 615, at 299.

${ }^{621}$ See Blaine Amendment Reconsidered, supra note 388, at 38.

${ }^{622}$ See Michael F. Holt, The Politics of Impatience: The Origins of Know Nothingism, 60 J. Am. Hist. 309, 311 (1973); see also Katz, supra note 613, at 118, n.15 (describing how the American Party used oaths to test Catholics' loyalty and put Catholics in precarious situations).

${ }^{623}$ Katz, supra note 613, at 112.

${ }^{624}$ See, e.g., Jeffries \& Ryan, supra note 615, at 302-03 (describing the church's opposition to secular education and freedom of conscience and noting that "Rome hampered attempts by American Catholics to abandon the Church's legacy by issuing reactionary pronouncements ideally suited to confirm the rankest prejudice"); STEPHEN MACEDO, DiVERSITY AND Distrust: CiVIC EDUCATION IN A MulTiCUlTURAL DEMOCRACY 61 (2000) (noting that America's
} 
motivated by a nativist skepticism of all immigrants, particularly Irish Catholics. ${ }^{625}$ Yet this seemingly secular nativism ultimately blended into religious prejudice. ${ }^{626}$ Anti-Catholic newspapers circulated, ${ }^{627}$ there were numerous incidents of mob violence against Catholics, and Catholic churches were burned down. ${ }^{628}$ Public schools were a means of assimilating Catholics, Jews, and other immigrants into the Protestant mold. ${ }^{629}$

In the 1860 s and 1870 s there was also a wave of radical secularism that was committed to "the absolute separation of church and state." ${ }^{630}$ The goal of these secular humanists was to terminate "all public appropriations for sectarian educational and charitable institutions" and that "no privilege or advantage shall be conceded to Christianity or any other special religion" at both the federal and state level. ${ }^{631}$ Secularists also demanded that "our entire political system shall be founded and administered on a purely secular basis." ${ }^{632}$ For these secularists, the Blaine Amendment was insufficient because it did not effectively wipe out religion from the public sphere. Secularists "viewed all Christians with the same fear and horror [that] Protestants

\footnotetext{
"core principles of individual freedom and democratic equality" seemed to conflict with the Catholic Church's "authoritarian institutional structure, its long-standing association with feudal or monarchical governments, its insistence on close ties between church and state, its endorsement of censorship, and its rejection of individual rights to freedom of conscience and worship"); Jay S. Bybee \& David W. Newton, Of Orphans and Vouchers: Nevada's "Little Blaine Amendment" and the Future of Religious Participation in Public Programs, 2 NEV. L.J. 551,555 (2002) (noting that "[t]he Vatican Decree of Papal Infallibility of 1870 added to the anti-Catholic sentiment during this time"); Hamburger, supra note 18, at 229-34 (discussing the church's condemnation of separation of church and state and reaction by American Protestants).

${ }^{625}$ See Hamburger, supra note 18, at 202; see also Thomas C. Berg, Anti-Catholicism and Modern Church-State Relations, 33 Loy. U. Chi. L.J. 121, 130 (2001) (discussing the "long history" of American anti-Catholicism).

${ }^{626}$ See Hamburger, supra note 18, at 202; see also Berg, supra note 625, at 130 (discussing the "long history" of American anti-Catholicism).

${ }^{627}$ Viteritti, supra note 615 , at 667.

${ }^{628}$ Hamburger, supra note 18 , at 216-7.

${ }^{629}$ Viteritti, supra note 615, at 668.

${ }^{630}$ Hamburger, supra note 18, at 290-293.

${ }^{631} I d$. at $294-95$.

${ }^{632}$ Id.
} 
reserved for Catholics." 633 Most shockingly, they even believed that "government benefits distributed on purely secular grounds could not be given to religious organizations."634

In 1875, the Blaine Amendment gained fervent momentum at the national level. President Ulysses S. Grant delivered an influential speech in which he said that Congress should "Encourage free schools, and resolve that not one dollar, appropriated for their support, shall be appropriated to the support of any sectarian schools." 635 Lest anyone think that Grant was endorsing secularism, Grant added that children should receive a "good common school education, unmixed with sectarian, pagan, or atheistical dogmas." ${ }^{636}$ Grant's speech was a clear attack on Catholics in an effort to align himself with Protestants as he sought a third term for President. ${ }^{637}$ On December 7, 1875, speaking before Congress, Grant called for "a constitutional amendment ... prohibiting the granting of any school funds, or school taxes, or any part thereof ... for the benefit or in aid, directly or indirectly, of any religious sect or denomination." ${ }^{\text {,638 James }}$ Blaine followed Grant's lead, and Blaine proposed his amendment to the federal Constitution on December $14,1875 .{ }^{639}$ Blaine's proposal was met with overwhelming support because it was seen "as a means of curbing the Catholic influence on school boards." 640 The national Blaine Amendment failed to clear the Senate, but states continued to amend their state constitutions with their own Blaine Amendments well into the Twentieth Century.

\section{B. The Supreme Court and the Blaine Amendments}

\footnotetext{
${ }^{633} \mathrm{Id}$. at 302.

${ }^{634}$ Id. at 304-05 n.43

${ }^{635}$ Blaine Amendment Reconsidered, supra note 388, at 47.

${ }^{636} \mathrm{Id}$.

${ }^{637}$ Viteritti, supra note 615 , at 670.

${ }^{638}$ Blaine Amendment Reconsidered, supra note 388, at 51.

${ }^{639}$ ("No State shall make any law respecting an establishment of religion, or prohibiting the free exercise thereof; and no money raised by taxation in any State for the support of public schools, or derived from any public fund therefor, nor any public lands devoted thereto, shall ever be under the control of any religious sect; nor shall any money so raised or lands so devoted be divided between religious sects or denominations."); Blaine Amendment Reconsidered, supra note 388, at 49-50 (citing The Index, Dec. 2, 1875, at 570)

${ }^{640} I d$. at 53 (citing Zion's Herald, Dec. 16, 1875, at 4; Dec. 23, 1875 at 4).
} 
The Supreme Court has never directly addressed the constitutionality of the thirty-seven Blaine Amendments in various State constitutions. ${ }^{641}$ The closest the court came to passing on this question was in Locke v. Davey ${ }^{642}$ where the Court considered the State of Washington's policy of not giving scholarship money to individuals seeking a religious education, even though it provided scholarships to individuals seeking a secular education. The plaintiff in Davey had his scholarship revoked once he took up religious study at a religious school but would have been able to maintain his scholarship if he had studied religion from a secular perspective. ${ }^{643}$ Chief Justice Rehnquist's majority opinion held that the states have "room for play in the joints" of the Establishment and the Free Exercise Clauses that allows the states in some contexts to facially discriminate against religion. ${ }^{644}$ Chief Justice Rehnquist explained that barring funding for religious education served the state's "antiestablishment interests," even though the court in Zelman had declared that this kind of funding was completely permissible under the Establishment Clause. ${ }^{645}$ Chief Justice Rehnquist emphasized that the state did not impose "sanctions on any type of religious service or rite" or deny "to ministers the right to participate in the political affairs of the community" or force "students to choose between their religious beliefs and receiving a government benefit." 646 These actions would certainly have violated the

\footnotetext{
${ }^{641}$ Various articles have argued that Blaine Amendments are unconstitutional. See, e.g., Mark Edward DeForrest, An Overview and Evaluation of State Blaine Amendments: Scope, and First Amendment Concerns, 26 Harv. J.L. \& Pub. Pol'y 551, 617-625 (2003) (arguing that Blaine Amendments violate freedom of speech); Heytens, supra note 610, at 140-52 (arguing that Blaine Amendments violate equal protection); Duncan, supra note 5 (arguing that Blaine Amendments violate the Free Exercise Clause); Ira C. Lupu \& Robert W. Tuttle, Zelman's Future: Vouchers, Sectarian Providers, and the Next Round of Constitutional Battles, 78 Notre Dame L. Rev. 917, 962 n.204, 967-971 (2003) (indicating that some Blaine Amendments could violate free speech principles); Rebecca G. Rees, "If We Recant, Would We Qualify?": Exclusion of Religious Providers from State Social Service Voucher Programs, 56 Wash. \& Lee L. Rev. 1291, 1313-1328 (1999) (explaining how Blaine amendments improperly restrict free speech). ${ }^{642}$ See 540 U.S. 712. In Mitchell v. Helms, 530 U.S. 793, 828-829 (2000), the Court noted the "shameful pedigree" of Blaine Amendments but did not address their constitutionality.

${ }^{643}$ See Davey, 540 U.S., at 716-717.

${ }^{644} \mathrm{Id}$. at 718 .

${ }^{645} I d$. at 722

${ }^{646} I d$. at 720 (citations omitted).
} 
Free Exercise Clause under existing Supreme Court precedent. Instead, the state had "merely chosen not to fund a distinct category of instruction." ${ }^{647}$ This was a sufficiently rational basis for the law, even though choosing not to fund an activity on the basis of race or gender would obviously violate the Fourteenth Amendment.

In dissent, Justice Antonin Scalia argued that the facts in Locke v. Davey warranted a direct application of the ban on facial discrimination on the basis of religion enunciated in the Church of the Lukumi Babalu case. Justice Scalia cited Brown v. Board of Education ${ }^{648}$ and Craig v. Boren and compared facial discrimination in schools on the basis of religion to facial discrimination in schools on the basis of race and gender, although he did not explicitly invoke the anti-discrimination command of the Fourteenth Amendment that we argue for in this article. ${ }^{649}$ Justice Scalia noted that Employment Division v. Smith only permitted facially neutral laws that disparately impacted religious practice, not facially discriminatory laws like the ones upheld in Locke v. Davey. Justice Scalia emphatically argued that the state did not have a legitimate governmental interest in barring government funding for religious students when government funding for similar secular studies was allowed. ${ }^{650}$

It is not clear, however, that the holding in Locke v. Davey should necessarily lead to upholding Blaine Amendments. Professor Douglas Laycock has argued that the holding in Locke v. Davey was a narrow one and that it only applies "to training of clergy, to refusals to fund that are not based on hostility to religion, and to cases that do not involve forums for speech."651 Blaine Amendments are blanket bans on government funding of any religious school or institution, not just bans on government funding of the clergy. They were also clearly motivated

\footnotetext{
647 Id.

648347 U.S. 483.

${ }^{649}$ Id. at 731 (Scalia, J., dissenting).

${ }^{650} \mathrm{Id}$. at 734.

${ }^{651}$ See Laycock, supra note 388, at 184.
} 
by a strong anti-Catholic bigotry in the Nineteenth Century. ${ }^{652}$ Accordingly, the Supreme Court could, consistent with Locke v. Davey, hold Blaine Amendments unconstitutional.

The United States Court of Appeals for the Tenth Circuit has similarly limited the application of Locke v. Davey in an important opinion by then-Judge Michael McConnell. ${ }^{653}$ In Colorado Christian Univ. v. Weaver, the Tenth Circuit struck down a state educational funding scheme that allowed government money to go to religious schools but that barred it from going to "pervasively sectarian" schools. ${ }^{654}$ Writing for the majority, Judge McConnell explained that under Locke v. Davey “the State's latitude to discriminate on the basis of religion is confined to certain 'historic and substantial state interest[s].",655 Accordingly, Davey "does not extend to the wholesale exclusion of religious institutions and their students from otherwise neutral and generally available government support." ${ }^{656}$ Only "minor burdens and milder forms of disfavor are tolerable in service of historic and substantial state interests" while "major burdens and categorical exclusions from public benefits" are problematic. ${ }^{657}$ Judge McConnell's opinion also held that discrimination on the basis of religion is subject to "heightened scrutiny" and could

\footnotetext{
${ }^{652}$ See generally Hamburger, supra note 18 . Some scholars argue that this overt bigotry alone should be sufficient to render Blaine Amendments unconstitutional. See, e.g., Thomas C. Berg, Vouchers and Religious Schools: The New Constitutional Questions, 72 U. Cin. L. Rev. 151, 199-208 (2003). Yet the Supreme Court has been skeptical of this argument. Davey, 540 U.S. at 735, n.7; Mitchell v. Helms, 530 U.S. 793, 828 (2000).

${ }^{653}$ But other circuits have said that Davey supports the notion that the Equal Protection Clause only provides religion with simple rational basis protection, as long as the law remains between "the joints." See, e.g., Wirzburger v. Galvin, 412 F.3d 271, 282-83 (1st Cir. 2005) (citing Davey, 540 U.S. at 721, n. 3); see also St. John's United Church of Christ v. City of Chicago, 502 F.3d 616, 638 (7th Cir. 2007) (citing same rule); Bowman v. United States, 304 F. App'x 371, 381 (6th Cir. 2008) (citing Davey).

${ }^{654} 534$ F.3d 1245.

${ }^{655} \mathrm{Id}$. at 1307 (citing Davey, 540 U.S. at 725).

${ }^{656} \mathrm{Id}$. at 1307.

${ }^{657} I d$. (quotations excluded).
} 
violate the Equal Protection Clause. ${ }^{658}$ Thus, the Tenth Circuit applied some sort of intermediate scrutiny for religion in place of the usual rational basis test.

\section{Blaine Amendments Constitute Class Legislation}

State Blaine Amendments easily violate the Fourteenth Amendment's ban on class legislation. Blaine Amendments facially discriminate on the basis of religion by explicitly carving out a special disadvantage for religious individuals as compared to secular individuals. Blaine Amendments fit precisely into the definition of class legislation "which is partial in its operation, intended to affect particular individuals alone, or to deprive them of the benefit of the general laws." ${ }^{, 659}$ The plaintiff in Davey lost his scholarship once he took up religious study at a religious school, but he would have been able to maintain it if he had studied religion from a secular perspective. ${ }^{660}$ This is a blatant instance of the government discriminating on the basis of religion. Other applications of Blaine Amendments could include: 1) allowing vouchers for students attending secular schools, but not for students attending religious schools; 2) allowing the funding of secular charities, but not of religious ones; or 3) denying any other government benefits or welfare payments to religious groups while upholding them for secular individuals. Blaine Amendments therefore constitute blatant discrimination on the basis of religion, and they are impermissible in the absence of a very compelling public purpose.

Blaine Amendments lack a legitimate public purpose because the types of funding that they outlaw are generally constitutional when the money goes to a secular school or institution. The Supreme Court has held that many forms of government funding of religious organizations

\footnotetext{
${ }^{658}$ Id. at 1266.

${ }^{659}$ Vanzant v. Waddel, 10 Tenn. (2 Yer.) 260, 269 (1829) (Peck, J.) (defining a partial law).

660 See Davey, 540 U.S. at 716-717.
} 
do not violate the Constitution. ${ }^{661}$ These holdings are consistent with the original meaning of the Establishment Clause which only banned actual establishments of religion. ${ }^{662}$ So, it seems quite difficult to claim that the Blaine Amendments serve an "antiestablishment" purpose ${ }^{663}$ when the Supreme Court has itself said that many of these kinds of funding programs do not actually violate the Establishment Clause. States could certainly have provisions in their state constitutions that parallel the federal Establishment Clause without violating the Fourteenth Amendment's ban on discrimination on the basis of religion. For example, states could ban direct funding of the clergy consistently with the anti-discrimination command of the Fourteenth Amendment. States could even augment the protections of the federal Establishment Clause in some contexts, as the states commonly do with other constitutional provisions. But states cannot augment a provision of the federal Constitution in a way that violates the Fourteenth Amendment's ban on discrimination on the basis of religion. We do not allow states to strengthen free speech protections in a way that discriminates based on race because doing so would violate the Fourteenth Amendment. Similarly, we should not allow states to strengthen federal Establishment Clause protections in a way that discriminates on the basis of religion. The simple desire not to fund religion, as a matter of conscience, is not a legitimate public purpose that can save the Blaine Amendments if the identical activity does get funded when done by a secular school or institution. The argument that taxpayers, as a matter of

\footnotetext{
${ }^{661}$ See Zelman, 536 U.S. at 652 (holding that a government voucher program that benefited students attending religious schools did not violate the Establishment Clause); Zobrest v. Catalina Foothills School Dist., 509 U.S. 1, 13-14 (1993) (holding that public employees may be placed in religious schools); Witters v. Washington Dept. of Servs. for Blind, 474 U.S. 481, 487 (1986) (holding that public funds could support a blind person at a religious school without violating the Establishment Clause); Mitchell v. Helms 530 U.S. 793 (2000) (allowing states to loan "educational materials and equipment" purchased with federal funds directly to religious and private schools); Rosenberger v. Rector of University of Virginia 515 U.S. 819 (1995) (holding that if a state university funds student magazines, it has to fund a student religious magazine).

${ }^{662}$ See supra Part IV.B.

${ }^{663}$ See Davey, 540 U.S. at 722 (explaining that not funding private religious organizations while funding parallel private secular organizations served an important antiestablishment interest).
} 
conscience, should not be forced to indirectly support religion by having their tax dollars go to religious organizations ${ }^{664}$ is not itself a public welfare rationale. The conscientious objection rationale may explain the ulterior motivations of supporters of Blaine Amendments, but it does not provide a constitutional defense for those amendments. To justify class legislation, a law must convey a general benefit that promotes the good of the whole people. Examples of class laws that promote the general good of the whole people include most of our police power laws which are designed to protect the public's health, safety, and economic autonomy. Simply banning a specific class of disfavored people who are religious from receiving government money does not promote a public purpose. Undoubtedly, there are white supremacists who - as a matter of conscience - object to government funds being spent for the benefit of AfricanAmericans. But, in our constitutional system, this is not an acceptable public purpose that could justify class legislation on the grounds that it was meant to benefit the general good of the whole people. Indeed, members of religious groups could argue quite plausibly that they conscientiously object to having their tax dollars used to fund a secular public school system. In Lawrence v. Texas, the Supreme Court struck down a Texas law banning sodomy because it lacked a "legitimate state interest," despite the fact that the law reflected local morals and conscience. ${ }^{665}$ The Court stated, "Freedom extends beyond spatial bounds. Liberty presumes an autonomy of self that includes freedom of thought, belief, expression, and certain intimate conduct.. ${ }^{, 666}$ If the Court can conclude that laws targeting gays and lesbians lack a public purpose, even though homosexuality is no where mentioned in the Constitution, unlike religion, then the Supreme Court should surely be able to say that laws discriminating on the basis of

\footnotetext{
${ }^{664}$ See, e.g., Americans United for Separation of Church and State, http://www.au.org/issues/religious-schoolvouchers/ (last visited April 12, 2011).

${ }^{665}$ Lawrence, 539 U.S. at 578.

${ }^{666} I d$. at 558 .
} 
religion are not general laws enacted for the good of the whole people. Such laws must instead be subjected to strict scrutiny.

Locke v. Davey's license to discriminate on the basis of religion in the context of educational funding could easily be transferred to many other sorts of government programs. Educational funding is merely one type of general welfare program designed to benefit the public. Educational funding is thus no different in principle from Medicare, Social Security, or even the provision of local fire protection services. ${ }^{667}$ Under the logic of Davey, the legislature could ban Medicare recipients from going to religious hospitals or prevent Social Security recipients from making donations to religious institutions. Or perhaps local communities, in keeping with the local residents" "freedom of conscience," could establish fire departments that protect secular schools and organizations, but not religious ones. The fact is that Davey is no more defensible than are any of these other forms of government discrimination on the basis of religion. What this shows is that Davey must be wrong.

How can the Supreme Court change course? The answer is that in Locke v. Davey, the Supreme Court was exclusively focused on the Free Exercise of religion question, and it failed to ask whether the state law in that case violated the equal protection doctrine by discriminating on the basis of religion. The majority in Davey concluded that revoking Davey's scholarship did not constitute a "prohibition" of religion within the meaning of the Free Exercise Clause. The parties and amici in Locke v. Davey were also primarily focused on the Free Exercise Clause question. Some of the briefs mentioned the Equal Protection Clause of the Fourteenth Amendment, but they did so only in passing. ${ }^{668}$ Neither the majority, the dissent, or any of the briefs gave any serious consideration to the Fourteenth Amendment anti-discrimination question. So the

\footnotetext{
${ }^{667}$ In Zelman, the Court effectively described Ohio's voucher program as a general welfare program, referencing the "[p]rogram benefits" to "participating families." 536 U.S. at 653.

${ }^{668}$ See, e.g., Brief for Respondent, Locke v. Davey, 540 U.S. 712, at *44-45.
} 
Fourteenth Amendment discrimination issue was not truly before the Court in Davey, even though it should have been. The parties never recognized that Washington State's law was an impermissible form of class legislation which violated the Fourteenth Amendment, and so the Court did not truly pass on that issue. In the future, the Supreme Court could and should simply take up the Fourteenth Amendment discrimination question.

\section{The Counterargument of the Blaine Amendments}

One possible counterargument to our thesis is that the sordid history of state Blaine Amendments shows that the original understanding of the Fourteenth Amendment was such that the Amendment was not thought to protect religious freedom at all. Since nine states had Blaine Amendments in 1868, and another twenty-four states added Blaine Amendments to their state constitutions by the end of the Nineteenth Century, it could be argued both that the Fourteenth Amendment did not incorporate the religion clauses of the First Amendment and that it did not ban discrimination on the basis of religion. This point is further underscored by the overt antiCatholic and, at times, anti-religious bigotry that accompanied these Blaine amendments.

This counterargument regarding religion actually mirrors a similar counterargument that could be made regarding discrimination on the basis of race and gender. In the years immediately following the ratification of the Fourteenth Amendment, racial segregation was widespread in the United States especially from 1877 to 1954. During the period between 1868 and 1920 and then again from 1937 to 1971 , discrimination on the basis of gender was also widespread notwithstanding the ratification of the Nineteenth Amendment in 1920. The Supreme Court's awful decisions in Plessy v. Ferguson, ${ }^{669}$ Bradwell v. Illinois, ${ }^{670}$ and Goesaert v. Cleary ${ }^{671}$ further justified and entrenched these discriminatory practices. The history of virulent discrimination

\footnotetext{
${ }^{669} 163$ U.S. 537 (articulating the principle of "separate but equal").

${ }^{6} 83$ U.S. 130 (1873).

671335 U.S. 464 (1948) (permitting states to prevent women from obtaining bartending licenses).
} 
against African-Americans and women following the ratification of the Fourteenth and

Nineteenth Amendments has led some to believe that a deviation from the original meaning of the Fourteenth Amendment is necessary to protect against racial or sex discrimination. ${ }^{672}$

But these arguments are mistaken ${ }^{673}$ The original expected applications of the Framers of the Fourteenth Amendment, much like their subjective intent, are simply not relevant to ascertaining the objective public meaning of the text of the constitutional provision that they wrote. A fitting analogy is someone who contracts to sell his house and at the closing refuses to hand over the keys to his garage, noting that the contract does not specify that the garage, which he did not intend to sell, was included in the sale of the house. The seller's expectations and subjective intent would be simply irrelevant in establishing the objective meaning of the contract which would instead be defined by local laws and customs. The Framers of the Fourteenth Amendment deliberately and knowingly used broad, unqualified language that went far beyond a simple ban on race discrimination. The original objective public meaning of Section One of the Fourteenth Amendment was to ban all forms of class legislation and all systems of caste. When the framers wanted to excise certain groups, such as aliens, from the broad protection of the Privileges or Immunities Clause, they crafted a text that explicitly applied only to citizens. The fact that the text mentions neither race, nor gender, nor religion, means that a general ban on all forms of class legislation was enacted. The fact that some or even many framers or other politicians failed to understand what the Amendment had done and thought that discrimination on account of race or religion was still permissible is irrelevant to the objective original public

\footnotetext{
${ }^{672}$ See, e.g., Ruth Bader Ginsburg, Sexual Equality Under the Fourteenth and Equal Rights Amendments, 1979 Wash. U. L.Q. 161, 161 (stating "[b]oldly dynamic interpretation, departing radically from the original understanding, is required to tie to the fourteenth amendment's equal protection clause a command that government treat men and women as individuals equal in rights, responsibilities, and opportunities").

${ }^{673}$ See also Calabresi \& Rickert, supra note 21, at 46-51 (discussing why expected applications are not relevant to ascertaining the original meaning of the text).
} 
meaning of the text. ${ }^{674}$ Instead, discrimination on the basis of race and religion became unconstitutional on the very day that the Fourteenth Amendment was ratified. To say otherwise is no better than the guy who wants to hold onto his garage.

\section{The Public School System}

We think that our argument that Blaine Amendments violate the Fourteenth Amendment leads to a further and perhaps startling conclusion. We think that the current American public school system violates the Fourteenth Amendment's ban on all forms of class legislation for two basic reasons. First, we think that states discriminate on the basis of religion when they administer secular public schools that are unpalatable to religious individuals and that are funded with taxpayer dollars. As already discussed, discrimination on the basis of religion is a form of class legislation that is banned by the Fourteenth Amendment. And many religious children constitute a caste because their religious status is inherited from their parents and is effectively immutable until they grow up. Indeed, some religions, including Judaism and Islam, do not even acknowledge conversions of their members to other faiths as being valid. Second, we also think that public school systems violate the Fourteenth Amendment because they are state-operated monopolies. These state-run public school monopolies are no different in principle from the types of state-granted monopolies that the Jacksonian Democrats fought against in the Nineteenth Century and that the Fourteenth Amendment banned. To rectify these breaches of the Fourteenth Amendment, we think that states are constitutionally obligated to give tuition vouchers to all students that they can use, if they wish, at the private school of their choice.

\section{A. Discrimination on the Basis of Religion}

\footnotetext{
${ }^{674}$ See Harrison, supra note 30, at 388 (discussing how the Framers of the Fourteenth Amendment were concerned that the Amendment could have broader implications than they expected or intended because they recognized that the objective meaning of the text, not the subjective intent, was controlling); see also Calabresi \& Matthews, supra note 30 (arguing that the Fourteenth Amendment banned antimiscegenation laws, despite the Framers' intent).
} 
Public schools discriminate on the basis of religion. Even though the education laws do not explicitly ban religious individuals from attending public schools, religious students are effectively excluded by the character of the public school curriculum, moral teachings in public schools, and general atmosphere at public schools. ${ }^{675}$ Public education is generally advertised as being secular, neutral, and open to all students. Yet neutrality in education is probably impossible because conveying values to children is an inherent aspect of education. ${ }^{676}$ Secularism and popular culture are incompatible with many religious belief systems, and public schools are simply incapable of teaching the religious values and doctrine that religious families often need. Indeed public education in America is neither neutral nor welcoming to all students, as public schools regularly promote political and social agendas at odds with religious views. ${ }^{677}$

In modern society, it is impossible to create a "neutral" educational environment. Religious and secular educators advance polar opposite approaches on such controversial topics as sex education, ${ }^{678}$ homosexuality, ${ }^{679}$ abortion, ${ }^{680}$ and standards of dress and decency. For instance, California recently enacted the California Fair Education Act which mandates that

${ }^{675}$ See Yoder, 406 U.S. at 209 (1972); Davis v. Page, 385 F. Supp. 395, 396 (D.N.H. 1974); Brusca v. Missouri, 332 F. Supp. 275, 276 (E.D. Mo. 1971); State v. Whisner, 47 Ohio St. 2d 181, 188, 199 (1976).

${ }^{676}$ See Viteritti, supra note 616, at 181-182 (discussing how there is nothing neutral about education); Suzanna Sherry, Responsible Republicanism: Educating for Citizenship, 62 U. Chi. L. Rev. 131, 156-182 (1995) (discussing the difficulty of finding a set of common, neutral educational values).

${ }^{677}$ See also Note, Government Neutrality and Separation of Church and State: Tuition Tax Credits, 92 Harv. L. Rev. 696 (1979) [hereinafter "Government Neutrality"] (arguing that the public school system violates the First Amendment's neutrality principles); Paulsen, supra note 16, at 358 (recognizing that the current public school system is not neutral and constitutionally problematic).

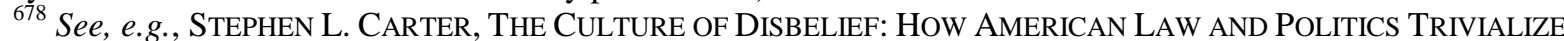
RELIGIOUs DEVOTION 171 (1993) (describing how the New York City public schools distributed condoms to all students without any opportunity to opt out, even though many parents complained that doing so violated their religious beliefs); NYC Schools to Give Mandatory Sex Ed Classes, Fox NEWS, http://www.foxnews.mobi/quickPage.html?page $=38321 \&$ content=54871073 (describing a controversial new program in New York City).

${ }^{679}$ See, e.g., ACLU Sues School for Censoring LGBT Websites, Fox NEWS, http://www.foxnews.mobi/quickPage.html?page=38321\&content=55192946 (describing a controversial policy in public schools).

${ }^{680}$ See, e.g., Abortion referral puts spotlight on school-based health centers, SEATTLE TIMES, March 25, 2010, available at $\mathrm{http}: / /$ seattletimes.nwsource.com/html/localnews/2011445397_abortion26m.html. 
educators, textbooks, and instructional materials positively promote "lesbian, gay, bisexual, and transgender Americans" as role models. ${ }^{681}$ Needless to say, this produced a strong backlash from religious groups opposed to these lifestyles. Balancing religion and science has also never been simple. The debate over creationism versus evolution is long-lived and impassioned. ${ }^{682}$ Which books should be read, or not read, ${ }^{683}$ as well as how to teach history are also regularly debated. ${ }^{684}$ And clashes between religious and secular factions frequently end up being litigated in court. ${ }^{685}$

The facts of Peck v. Baldwinsville Central School District ${ }^{686}$ are instructive of the religion versus secularism controversy in public schools. ${ }^{687}$ There, a kindergartener had drawn a picture of Jesus as part of a class assignment. The school district censored the picture in furtherance of its antiestablishment interests. The Second Circuit sided with the Ninth and Eleventh Circuits, holding that schools may not censor students in this curricular context. But the First and the Tenth Circuits permit this form of censorship. ${ }^{688}$ One would not expect a neutral public school program, palatable to all, to produce a heated circuit split.

${ }^{681}$ CAL. EDUC. CODE $\$ 51204.5$ (2012).

${ }^{682}$ See generally Note, Freedom of Religion and Science Instruction in Public Schools, 87 Yale L.J. 515 (1978) (describing the conflict between creationism and evolution in public school education); EDWARD J. LARSON, SUMMER FOR THE GODS: THE SCOPES TRIAL AND AMERICA'S CONTINUING DEBATE OVER SCIENCE AND RELIGION (1997) (analyzing the Scopes trial).

${ }^{683}$ See, e.g., Idaho School Shut Down Over 'Religious Texts, ' Fox NEWS, http://www.foxnews.mobi/quickPage.html?page=38321\&content=56587012 (describing controversy over using Bible to teach history).

${ }^{684}$ See, e.g., Michael Jennings, Kentucky Asks What Year Is It?, CHRISTIANITY TODAY, May 31, 2006, http://www.christianitytoday.com/ct/2006/mayweb-only/122-32.0.html (describing controversy over a school board's proposal to substitute "C.E. (Common Era) for A.D. and B.C.E. (Before Common Era) for B.C.") ${ }^{685}$ See, e.g., Mozert v. Hawkins County Bd. of Educ., 827 F.2d 1058 (6th Cir. 1987) (upholding a school board's decision to reject parents' request that their children be accommodated with readings that did not promote ideas contradicting their religious values; Altman v. Bedford Cent. Sch. Dist., 245 F.3d 49 (2001) (dispute over a "New Age" curriculum that parents claimed was religious and which the school board ultimately agreed to modify). ${ }^{686}$ Peck ex rel. Peck v. Baldwinsville Cent. Sch. Dist., 426 F.3d 617 (2d Cir. 2005).

${ }^{687}$ See Harry G. Hutchison, Shaming Kindergarteners? Channeling Dred Scott? Freedom of Expression Rights in Public Schools, 56 Cath. U. L. Rev. 361, 365 (2007) (discussing this case).

${ }^{688}$ See Fleming v. Jefferson County Sch. Dist. R-1, 298 F.3d 918, 926-29 (10th Cir. 2002) (permitting “educators to make viewpoint-based decisions about school-sponsored speech"); Ward v. Hickey, 996 F.2d 448, 450 (1st Cir. 
The overall environment of public schools is also incompatible with many religions' beliefs. Many religions forbid pre-marital sex and foul language and are simply repulsed by a popular culture that endorses these behaviors. Many religious groups are also skeptical of modern materialism which seems to equate happiness with physical possessions. And they are concerned about the way women are objectified in the media and popular culture, and how young girls and boys are consequently impacted. For these reasons, many religious parents are careful about which kinds of movies, television shows, or websites they allow their children to view. And, quite predictably, many religious parents do not want their children in a militantly secular school where their beliefs are trivialized or are described as being bigoted.

Many religions also require that a specific religious curriculum be taught to students of their faith. For instance, Orthodox Jewish schools typically spend a large portion of the day teaching religious subjects that include the study of scripture, Jewish law, and Jewish ethics. ${ }^{689}$ Many Christian and Muslim schools have similar programs, depending on the needs of their respective student bodies.

Today public schools are almost all militantly secular institutions. This is in part the fault of the Supreme Court which has outlawed prayer and Bible study in public schools. Under the Supreme Court's Establishment Clause case law, Bible readings and prayer in public schools are unconstitutional, even if some students are absent or can be excused from these activities. ${ }^{690}$ Problems also arise if a school proscribes religious exercises, ${ }^{691}$ teaches creationism, ${ }^{692}$

1993) (allowing a public school committee to refuse to reappoint a biology teacher who discussed abortion based on her opinion in class).

${ }^{689}$ See Brief of the National Jewish Commission on Law and Public Affairs ("COLPA") as Amicus Curiae in Support of Respondent, Locke v. Davey, 540 U.S. 712 (2004) (describing the central role of religious education for Jewish students); see also M. HERBERT DANZGER, RETURNING TO TRADITION: THE CONTEMPORARY REVIVAL OF ORTHODOX JUDAISM 149-151, 278 (1989) (describing how Orthodox Jews' combine religious and secular studies).

${ }^{690}$ Schempp, 374 U.S. 203.

${ }^{691}$ Florey v. Sioux Falls School Dist. 49-5, 619 F.2d 1311 (8th Cir. 1980). 
distributes the Bible in school, ${ }^{693}$ or otherwise sponsors a religious message. ${ }^{694}$ Other potential land mines include voluntary prayer, moments of silence, student sponsored events, sporting events, and graduation ceremonies. ${ }^{695}$

Public schools are also largely secular because most public school administrators believe that teaching a rigidly secular dogma is best both for public school students and for society. This is perhaps in part a result of the increased pluralism in American society which has created a need to find a middle ground common to everyone. ${ }^{696}$ Public schools have been forced by the courts to adopt a "no endorsement" policy in a futile attempt not to alienate anyone. ${ }^{697}$ But in practice, many religious students are in fact alienated and marginalized.

Modern secular humanism is a core, almost religious, belief system of modern liberalism. Secular humanists distrust - and sometimes even dislike - religion. ${ }^{698}$ Modern secular humanism teaches values and opinions that are often wholly inconsistent with religious teachings. ${ }^{699}$ Though so-called modern "liberals" pretend to favor concepts such as "neutrality," "tolerance," and "independent thinking," liberal educators in practice often have little or no tolerance for

${ }^{692}$ See Edwards v. Aguillard, 482 U.S. 578 (1987).

${ }^{693}$ Goodwin v. Cross County School Dist. No. 7, 394 F. Supp. 417 (E.D. Ark. 1973).

${ }^{694}$ Santa Fe Independent School Dist. v. Doe, 530 U.S. 290 (2000).

${ }^{695}$ See 16A C.J.S. Constitutional Law § 762

${ }^{696}$ Hutchison, supra note 687 , at 363.

${ }^{697}$ Id. at 377-378.

${ }^{698}$ See Marci A. Hamilton, Power, The Establishment Clause, and Vouchers, 31 Conn. L. Rev. 807, 826 (1999) (arguing that vouchers disturb the balance of power between government and religion that the Establishment Clause was designed to control); Viteritti, supra note 616, at 180-181 (describing secularist John Dewey’s strong opposition to religion); See also Justice Stevens' dissent in Zelman (noting "religious strife" in other countries and remarking, "Whenever we remove a brick from the wall that was designed to separate religion and government, we increase the risk of religious strife and weaken the foundation of our democracy."); Justice Souter's dissent similarly referenced "sectarian religion's capacity for discord."

${ }^{699}$ See Stanley Ingber, Socialization, Indoctrination, or the "Pall of Religious Orthodoxy": Value Training in the Public Schools, U. Ill. L. Rev. 15 (1987); MARK G. YudOF, WHEN GOVERNMENT SPEAKS: POLITICS, LAW AND GOVERNMENT EXPRESSION IN AMERICA 52-55 (1983). 
religious views that are incompatible with the tenants of modern liberalism. ${ }^{700}$ Excluding religious views from the classroom is in fact important to effectively convey liberal secular humanist ideology to public school students. ${ }^{701}$ The result is that "common schools" are unable to incorporate different viewpoints and bring true religious diversity into the classroom. ${ }^{702}$

The use of facial neutrality as a façade for the exclusion and intolerance of those who hold a religious belief is not a new practice for the public school system. From the moment public schools were founded by Horace Mann in the Nineteenth Century, they were infused with majoritarian intolerance of minority religions. Mann advertised his "common schools" as inclusive and open to everyone without a bias for any particular religious denomination. ${ }^{703}$ The curriculum was designed to be a "pan-Protestant compromise, a vague and inclusive Protestantism." ${ }^{704}$ In justifying the practice of reading the Bible without commentary, Mann said that, "Our system earnestly inculcates all Christian morals; it founds its morals on the basis of religion; it welcomes the religion of the Bible; and in receiving the Bible, it allows it to do what it is allowed to do in no other system, to speak for itself., ${ }^{, 705}$ Yet Mann's schools were not at all bastions of religious inclusiveness. Instead their curricula were based solely on Protestant teachings and were wholly intolerant of any other form of Christianity or of any other religion. ${ }^{706}$ While reading the Bible without commentary might seem to be neutral on its face, such a

\footnotetext{
${ }^{700}$ Hutchison, supra note 687 , at 382.

${ }^{701}$ See, e.g., Jerry Buell, Florida High School Teacher, Suspended For Anti-Gay Facebook Posts, HuFFINGTON POST, available at http://www.huffingtonpost.com/2011/08/19/jerry-buell-florida-high-_n_931941.html (last visited December 29, 2011); see also Hutchison, supra note 687, at 361 n.1 (describing controversies in San Francisco).

702 See Rosemary C. Salomone, Common Schools, Uncommon Values: Listening to the Voices of Dissent, Yale L. \& Pol'y. Rev. (1996)

${ }^{703}$ See Jeffries \& Ryan, supra note 615, at 78-79.

${ }^{704} \mathrm{Id}$.

705 See Anson Stokes, Church \& StATE IN THE United States, 57 (1950) (quoting Report to the Board of Education in 1848).

${ }^{706}$ Viteritti, supra note 615, at 666 ("The American common school was founded on the pretense that religion has no legitimate place in public education. But in reality it was a particular kind of religion that its proponents sought to isolate from public support. The common-school curriculum promoted a religious orthodoxy of its own that was centered on the teachings of mainstream Protestantism and was intolerant of those who were non-believers.")
} 
practice was in truth designed to shut out non-Protestant teachings and was deeply offensive to Catholics. ${ }^{707}$ Mann said that "sectarian books and sectarian instruction, if their encroachment were not resisted, would prove the overthrow of the schools."708 The word "sectarian" here was code for Catholic. Mann's schools reflected a national trend in public education: states operated public schools that were allegedly "nonsectarian" but that were in fact incredibly intolerant of non-Protestant denominations. ${ }^{709}$ Other countries have had similar historical experiences where majoritarian groups integrate allegedly neural values into systems of public education that turn out to be nothing more than a façade for the oppression of religious minorities. ${ }^{710}$ If history is any indicator, there is nothing neutral about neutrality in the context of public education.

Public education has long been advertised as being a government benefit that is available to the whole population, but it is in reality a form of class legislation because it is simply unacceptable to religious individuals unless they have no other choice. A widely recognized phenomenon in anti-discrimination law is to understand that a racially hostile environment or a sexist or harassing environment is a form of race and gender discrimination. Public schools could not and should not be able to teach racist or sexist literature, and public school teachers cannot and should not be able to make racist or sexist comments in class. The same principle applies to discrimination on the basis of religion in schools. It is not enough for the government to avoid discrimination in hiring teachers or admitting students. The government must also not create a hostile learning environment for devoutly religious students. Teaching Orthodox Jews or fundamentalist Christians or devout Muslims that non-marital sex is acceptable creates a

\footnotetext{
${ }^{707}$ See Duncan, supra note 5, at 504.

${ }^{708}$ See Stokes, supra note 705, at 57 (quoting Report to the Board of Education in 1848).

${ }^{709}$ Viteritti, supra note 615, at 666-667.

${ }^{710}$ See e.g., STEPHEN V. MONSMA \& J. Christopher SOPER, THe Challenge OF Pluralism: Church and State IN FIVE DEMOCRACIES, 55-56 (2009) (describing the experience of the Netherlands in the Eighteenth Century); Asher Maoz, Religious Education in Israel, 83 U. Det. Mercy L. Rev. 679, 682-683 (2006) (describing how religious groups in Israel successfully blocked secular attempts to define a set of common universal values).
} 
forbidden form of a religiously hostile environment. Banning prayer and Bible study in classes does the same thing. For this reason alone, it is obvious that the modern day secular public schools are engaged in a systemic form of discrimination on the basis of religion.

This point can be further illustrated with an analogy. Suppose a state decided to buy clothing for its residents. But instead of buying different clothing for men and women, the state just bought men's clothing and offered it to everyone on equal terms. Undoubtedly the program would be unconstitutional because men's clothing is fundamentally unfit for women. Similarly, our militantly secular public schools are fundamentally unfit for religious students. They offer a learning environment that is hostile to religion and therefore discriminates on account of religion.

Consider another hypothetical. Suppose that the government decided to shut down the entire public school system and instead gave all students tuition vouchers, which they could use to attend the private school of their choice. Suppose further that the government stipulated that those education vouchers could only be used at secular schools, and not at religious ones. Such a selective funding program would clearly constitute facial discrimination on the basis of religion. ${ }^{711}$ Our current public school system is simply the publically operated version of that secular voucher program. Instead of funding only secular private schools, the government funds only secular public schools. Why should a program that funds only secular public schools be considered any less discriminatory than a program that funds only secular private schools?

The discriminatory impact of the secular public school system is compounded by the enormous financial burden that the current system places on religious families. Religious families that are poor simply may not be able to afford private school tuition for their children. ${ }^{712}$

\footnotetext{
${ }^{711}$ See supra Part V.C.

712 See Private Schooling, EDUCATION WEEK, April 4, 2004, http://www.edweek.org/ew/issues/private-schooling/ (discussing how the cost of private education prevents many families from sending their children to private schools and how this cost disparately impacts poor families and racial minorities).
} 
Consequently, they are forced to send their children to secular public schools against their religious beliefs. Once there, students are exposed to a learning environment that is enormously hostile to their religious beliefs. Racial minorities are especially likely to be disparately impacted by this predicament. ${ }^{713}$ And this problem is exacerbated by mandatory education laws which obligate all children between certain ages to attend a school. Even Wisconsin v. Yoder only exempted religious school attendance beyond the eighth grade. Poor religious parents who could not afford a private school for their first grader would undoubtedly be forced to send him or her to a secular public school with an environment that is hostile to their religion. For a religious family, sending a child to a secular public school could easily constitute a substantial and irreparable harm for the reasons described above. From a religious family's perspective, the degree of harm could be comparable to the harm caused by discriminatory sterilization laws in Skinner v. Oklahoma. Religious children may grow up to be atheists, much to their parents' profound dismay. Even religious families that can afford private schools suffer substantial damage from the public school system because private school tuition is often expensive.

The financial burden is compounded by the gross inequity of forcing religious families to pay for secular public schools as taxpayers in addition to paying private school tuition. ${ }^{714}$ Public schools are paid for by taxpayers at the local, state, and federal levels, yet private schools are funded solely by parental fees and private donations. Religious families are therefore forced to subsidize the education of secular students - while religious families get nothing in return. This

\footnotetext{
${ }^{713} I d$.

${ }^{714}$ In Committee for Public Education \& Religious Liberty v. Nyquist, the Supreme Court recognized the burden that the current system places on families sending their children to private schools. 413 U.S. 756, 783 (1973). But the court struck down a tax benefit plan for families sending their children to private schools because " $[\mathrm{h}]$ owever great our sympathy ... for the burdens experienced by those who must pay public school taxes at the same time that they support other schools because of the constraints of 'conscience and discipline,' [this may not] justify an eroding of the limitations of the Establishment Clause now firmly emplanted." Id. at 788-89 (citations omitted).
} 
form of wealth redistribution based purely on religious distinctions is reminiscent of the religious taxes placed on members of disfavored minority religions, such as Jews and Catholics, in Europe. ${ }^{715}$ Governments at all levels in the United States have effectively decided that secular education is the winner, religious education is the loser, and that religious families must therefore open their pocketbooks. If the ACLU has conscientious objector taxpayer standing to object to Christmas and Hanukkah displays, then surely religious parents have conscientious objector status to sue over being taxed to pay for militantly secular public schools with a learning environment that is illegally hostile to religion.

To make matters worse, the government's policy of discriminating on the basis of religion incentivizes religious individuals to actually become secular. This is true because government programs fund only secular education, ${ }^{716}$ and this encourages religious individuals to attend militantly secular public schools in violation of their core religious beliefs. The obvious consequence is that those students will be less well educated in their own religious traditions, less committed to their religions, and more likely to embrace militant secularism and materialism. Governments in the United States have not outlawed religious schools, which might violate the Free Exercise Clause, but they have gone around the Free Exercise Clause by creating a very substantial financial incentive for children to abandon the religious traditions of their

\footnotetext{
715 See Jewish Virtual Library, http://www.jewishvirtuallibrary.org/jsource/vjw/England.html\#Rule\%20of\%20Henry\%20III\%20and\%20the\%20Bar ons\%20Wars\%20\%281217-1290\%29 (last visited May 14, 2012) (describing the rule of Henry III and the Barons Wars (1217-1290)); Ybo Buruma, Dutch Tolerance: On Drugs, Prostitution, and Euthanasia, 35 Crime \& Just. 73 , 78 (2007) (discussing special taxes on Catholics in the Netherlands in the seventeenth century).

716 See Government Neutrality, supra note 624, at 703-705 (describing how government programs to provide construction aid for secular private schools, but not religious ones, incentivized religious schools to become more secular so that they could qualify for the funding); Sherbert 374 U.S. 398; Thomas, 450 U.S. 707.
} 
families. ${ }^{717}$ And the proof is in the pudding: since the Supreme Court began striking down religious instruction and prayer in schools in the early $1960 \mathrm{~s},{ }^{718}$ religious affiliation has dropped from over $90 \%$ of the American public to approximately $77 \% .{ }^{719}$ Over the same time period, the percentage of individuals who have no religious identification has increased from around $2 \%$ to approximately $16 \% .{ }^{720}$ When schools lack religious instruction or maintain a learning environment that is hostile to religion or even openly denigrate religion, children will simply lack the connection and the education they need to lead a virtuous and religious life. Therefore despite the Supreme Court's affirmation in Pierce v. Society of Sisters that families have a constitutional right to educate their children according to their own religious beliefs, the public school system in the United States transforms that right into a mere fantasy for families who are unable to overcome the financial burdens of paying for a private religious education. The end result is a government-mandated subsidy of secularism.

The words of the Supreme Court underscore the paramount significance of private religious education. In Society of Sisters, the Court struck down a state law that would have forced children to attend public school because the law "unreasonably interferes with the liberty of parents and guardians to direct the upbringing and education of children."721 The court said,

The fundamental theory of liberty upon which all governments in this Union repose excludes any general power of the State to standardize its children by forcing them to accept instruction from public teachers only. The child is not the mere creature of the State; those who nurture him and direct his destiny have the

\footnotetext{
${ }^{717}$ In the free exercise context, the Supreme Court has recognized the coercive power of forcing individuals to choose between government benefits and their religious beliefs. See Sherbert v. Verner, 374 U.S. 398; Thomas, 450 U.S. 707.

${ }^{718}$ See Engel, 370 U.S. 421; Schempp, 374 U.S. 203.

${ }^{719}$ Frank Newport, This Easter, Smaller Percentage of Americans Are Christian, GALluP, April 10, 2009, http://www.gallup.com/poll/117409/easter-smaller-percentage-americans-christian.aspx (see table).

${ }^{720}$ Frank Newport, In U.S., Increasing Number Have No Religious Identity, GALLUP, May 21, 2010, http://www.gallup.com/poll/128276/increasing-number-no-religious-identity.aspx (see table).

${ }^{721}$ See Society of Sisters, 268 U.S., at 534.
} 
right, coupled with the high duty, to recognize and prepare him for additional obligations. $^{722}$

In Wisconsin v. Yoder, the Supreme Court added, "the values of parental direction of the religious upbringing and education of their children in their early and formative years have a high place in our society." ${ }^{, 723}$ And in Abbington School District v. Schempp, Justice William J. Brennan wrote, "The choice between public secular and private or sectarian education is one-very much like the choice of whether or not to worship-- which our Constitution leaves to the individual parent. It is no proper function of the state or local government to influence or restrict that election." 724 But our current public school system with no education vouchers for religious students violates these core principles by strongly favoring a secular education and by economically penalizing a religious education.

Discrimination on the basis of religion in this context cannot be defended on the ground that funding public schools is a general law that promotes the good of the whole people and that therefore serves a compelling government interest. As already explained, the public schools are unacceptable to religious individuals because they are permeated with a learning environment that is openly hostile to religion. For a law to be a general law, it must benefit almost everyone or at least be available for almost everyone. Roads and parks can be created by the use of powers of eminent domain because they are available for everyone. Many occupational licensure laws and requirements that one have a driver's license to drive are for the same reason general laws that benefit the whole people. But the funding of public schools with an environment that is hostile to religion coupled with a refusal to give religious students an education voucher is not a general law that promotes the good of all the people nor is it justified by any compelling governmental

\footnotetext{
${ }^{722}$ See Id., at 535.

723406 U.S. at, $213-14$.

724374 U.S., at 242 (Brennan, J., concurring).
} 
interest. If the government wants to fund education, then public funds must be made available to all individuals in a way that does not require the religiously devout to learn in an environment permeated by hostility to religion. If a government policy had a disparately negative impact on a racial minority or on one gender, it would certainly be intolerable. Policies that have such an impact on religion should not be viewed any differently. We would never tolerate a public school that approvingly taught a racist book like Little Black Sambo, by Helen Bennerman, or a sexist magazine that contained pornographic material denigrating women. We should be equally intolerant of a system of public education that forces devoutly religious children to learn in an environment that is saturated with contempt for religion.

Even if the secular public school system served a compelling public interest and was a general law enacted for the good of the whole people, the discriminatory impact of the current public school system on religion fails the Sherbert-Yoder balancing test. That test requires the government to pursue its goal in a manner that has the least restrictive impact on religion. What is the government's goal? If the goal is to educate children broadly, then the least restrictive means requires that the government fund education for all children and not only for secular children. Paying for only secular public schools but not for religious ones is not the least restrictive means by which the government can pursue its objective. And if the government's true goal is to narrowly provide only secular education, but not religious education, then that goal is impermissible because it discriminates on the basis of religion. There is simply no good reason for the government to decide that education devoid of religion is objectively better than education involving religion. As a policy matter, asserting that secular education is superior to religious education is utterly baseless because religious schools have existed for several millennia and have successfully educated students over that whole period of time. Most of our 
major private universities, including Yale and Harvard, originated as religious schools. And secular public schools in this country have had, shall we say, somewhat mixed results. But more critically, deciding that education devoid of religion is objectively better than education involving religion is an illegitimate goal because it constitutes discrimination on the basis of religion. The government certainly could not maintain an education policy designed to educate whites but not blacks or men but not women. Why should an education policy designed to benefit only secular children and not religious children be any different?

Some argue that private schools should not be funded by the government because only wealthy families send their children to private schools. This argument is problematic for several reasons. First, private schools are populated by children from low and middle income families. ${ }^{725}$ The words of Maimonides, the great twelfth century Codifier of Jewish Law, exhibit the extremity to which fervently religious people will go to pursue religious study:

Every Israelite is under an obligation to study Torah, whether he is poor or rich, in sound health or ailing, in the vigor of youth or very old and feeble. Even a man so poor that he is maintained by charity or goes begging from door to door, as also a man with a wife and children to support . . . [as scripture says,] 'But you shall meditate therein day and night., 726

Needless to say, individuals with Maimonedes' perspective will not be dissuaded from attending private religious schools, even if doing so comes at great financial hardship. Second, the argument is premised on the notion that wealthy families should be entitled to fewer government benefits than non-wealthy families. That logic is itself a classic example of class legislation, violating Locke's maxim that there should be "one rule for rich and poor." "727 And third, many

\footnotetext{
725 See UnITED STATES CENSUS BuREAU, CPS October 2010, Table 3, available at www.census.gov/hhes/school/data/cps/2010/tables.html.

${ }^{726}$ MishnAH TORAH, Book 1, The Laws Concerning the Study of the Torah, Ch. 1 (citing Joshua 1:8).

${ }^{727}$ CONSTITUTIONAL LimitATIONS, supra note 100, at 459.
} 
wealthy families send their children to public schools without paying extra fees or tuition. ${ }^{728}$ So, the notion that educational benefits are distributed based on wealth is utterly without merit. The real dividing line between the public and the private schools is religion. Those families who can tolerate secular education - whether rich or poor - can enjoy tuition-free education. And those families whose religious beliefs require that their children attend religious schools or who object to a public school learning environment that is hostile to religion must pay through the nose for their private school education. That is discrimination on the basis of religion - plain and simple.

Just to be crystal clear about our argument, the problem with American public schools is one of discrimination on the basis of religion, not one of the denial of fundamental rights. The government has no obligation to fund religious education as a substantive right, just as it has no obligation to fund abortions, church construction, or most other substantive constitutional rights that private individuals enjoy. If the government would choose not to fund any education at all that would be constitutionally permissible. But what the government cannot do is fund education discriminatorily. If the government chooses to fund education, as it has, it must do so evenhandedly without distributing benefits by discriminating on the basis of religion. ${ }^{729}$

\section{B. Education Monopoly}

\footnotetext{
${ }^{728}$ See UnITED STATES CENSUS BuREAU, CPS October 2010, Table 3, available at www.census.gov/hhes/school/data/cps/2010/tables.html.

${ }^{729}$ This reasoning does not require the government to fund abortions, even though it funds live births, because there is a significant public purpose in favoring live births over abortions. See also Government Neutrality, supra note 624 , at 701, n.34 (arguing that the need for government neutrality in educational funding is much more compelling because education is much more expensive than abortion); but see Maher v. Roe, 432 U.S. 464, 484-85 (1977) (Brennan, J., dissenting) (arguing that the government must subsidize abortions if it subsidizes live births because the funding disparity skews individual choice away from abortions, thereby infringing on the right to privacy). Additionally, religion as a right is unquestionably protected in the text of the Constitution itself, whereas the existence of a constitutional right to abortion is hotly debated. See, e.g., Planned Parenthood of Southeastern Pennsylvania v. Casey, 505 U.S. 833 (1992) (Scalia, J. dissenting).
} 
The public school system is a monopoly, no different from the Nineteenth Century government-granted monopolies which the Fourteenth Amendment outlawed along with all other class legislation. As already discussed, the Framers of the Fourteenth Amendment had a Jacksonian concern with the evils of government-granted monopolies or government grants of special "privileges" or "immunities" conferred on only a few crony capitalists. The Privileges or Immunities Clause and the Equal Protection Clause were originally understood as banning monopoly and class legislation by securing equally to all citizens all of the privileges or immunities of both federal and of state citizenship. Professor Calabresi has set out the originalist argument that state government grants of monopoly violate the Fourteenth Amendment in extensive detail in another article, and we will therefore not repeat those arguments here. ${ }^{730}$ It suffices here to say that government grants of monopoly are only permissible under the original understanding of the Fourteenth Amendment if they are contained in general laws that benefit the whole people. Occupational licensure laws for brain surgeons and airplane pilots undoubtedly satisfy this test, but the present day militantly secular public school monopoly does not.

The President of the American Federation of Teachers, Albert Shanker, once remarked about American education that, "public education operates like a planned economy .... [O]ur school system ...more resembles the communist economy than our own market economy."731 Indeed it does. In 2009-2010, approximately ninety percent of all K-12 students attended public schools. ${ }^{732}$ In the context of the private economic sector, that statistic would by itself easily trigger an antitrust lawsuit. ${ }^{733}$ But here we just call it a public service that is secured by a

\footnotetext{
${ }^{730}$ Steven G. Calabresi \& Larissa Price, Monopolies and the Constitution: The Legal Case Against Crony Capitalism, unpublished manuscript posted on SSRN and on file with the authors.

${ }^{731}$ See Charles Fried, Five to Four: Reflections on the School Voucher Case, 116 Harv. L. Rev. 163, 198 n.4 (2002) (citing Reding, Wrighting, \& Erithmatic, Wall St. J., Oct. 2, 1989, at A14).

732 Council for American Private Education, http://www.capenet.org/facts.html (last visited March 21, 2012).

733 See JOHN MERRIFIELD, THE SCHOOL CHOICE WARS 9 (2001); Fried, supra note 731, at 198 n.4.
} 
government grant of special privilege. Years ago, some states tried to gobble up that final ten percent by banishing private education, but the Supreme Court slammed on the breaks in Pierce v. Society of Sisters. ${ }^{734}$ Currently the fifty states retain their dominant market position by simply relying on their financial power. The states refuse to fund private education at all, or they choose to fund only some private schools that meet certain very specific criteria. The unsavory effects of the government conferred public school monopoly are the same as the unsavory effects that appear with most government grants of monopoly power. There are: 1) fewer consumer choices, 2) higher costs to consumers, 3) lower quality services, and 4) a discriminatory benefit that only accrues to the monopolist in this case public school administrators and teachers. ${ }^{735}$

It is important to stress that the public school monopoly is government-granted, just as were all monopolies prior to the adoption of the Sherman Antitrust Law in $1890 .{ }^{736}$ When the Jacksonians railed against the evils of monopolies, their principal objection was to government grants of special privileges to a single citizen or class of citizens. The government has granted itself control over the public schools, just as it granted control of the railroads to particular private companies which were given the power to take private land by eminent domain.

But the public school monopoly is especially pernicious because the revenue for the public schools comes from all taxpayers. Consumers are forced to pay for a monopoly system of public education, whether they want to or not, so the public schools do not even have to go out and convince consumers to purchase their services. In contrast, no legislature has ever in any other context forced consumers to actually purchase products from a government-granted monopoly. When English Kings and Queens granted a monopoly on the right to produce playing

\footnotetext{
${ }^{734}$ See Society of Sisters, 268 U.S. 510 (striking down a law forcing parents to send their children to public schools); Meyer, 262 U.S. 390 (striking down a requirement that both public and private schools teach only English).

735 See generally Milton Friedman \& Rose Friedman, Free to ChOOSE: A PERSONAL STATEMENT 150-88 (1980) (discussing the problems with public schools).

${ }^{736}$ See generally Calabresi \& Price, supra note 730.
} 
cards to a royal favorite, they never required that the public buy those playing cards and thus pay the monopoly rent. Governments in the United States have sometimes favored specific companies, such as railroad companies, and they have also created unfair marketplaces where consumer choice is limited, ${ }^{737}$ but they have never in any other context actually forced consumers to pay for the monopolist's services whether they used those services or not.

The fact that the consumers of education are forced to pay for the government's educational services is especially problematic in light of this country's religious diversity. As already explained, a public school that creates an environment that is openly hostile to religion is simply not an option for many religious families. ${ }^{738}$ Families for whom religion is an integral part of their lives are therefore forced to pay for militantly secular public schools to which they would never send their own children - not in their wildest dreams. Public funding of militantly secular schools is equivalent to forcing a consumer to a buy a product for himself which he abhors, telling him that the product is actually good for him, and then refusing to give him back his money when he demands it. Even the most overbearing government and private monopolies cannot actually force consumers to buy a product that they do not want. Most monopolies survive and flourish by taking advantage of consumers who already want to purchase their product. But generating revenue from people who actually detest the product being offered requires a level of coerciveness that is unique to the public school system. Forced support for militantly secular public education is not at all similar to state laws that require that we all purchase car insurance. Such laws are general laws that promote the good of the whole people and that are justified by a compelling governmental interest. Nor are the laws establishing the public school monopoly at all similar to government funding of roads and parks which are open

\footnotetext{
${ }^{737}$ See Id. at 6 (describing how Queen Elizabeth I dished out harsh punishments for violating monopoly laws).

${ }^{738}$ See supra p.134-140.
} 
and available to the entire public. They are instead comparable to President Obama's individual mandate which compels individuals to purchase health insurance, even though those individuals might have wanted to stay out of the health insurance market altogether. In the education context as with the healthcare mandate, the states force individuals to pay tuition to public schools, even though those individuals might never want to attend a public school.

To make matters worse, families that manage to send their children to private schools are forced to pay two tuitions - one for public school and one for private school. Even the most onerous monopolies would never be able to force consumers to purchase their products even though those consumers had already gone out and purchased a competing product. The combination of the economic inefficiency and injustice of this result is truly staggering.

As with any monopoly, the public school system decreases consumer choice by eliminating competition. A monopoly's dominant market position allows it to muscle competitors out of the marketplace. Here, competing services (i.e., private schools) are dramatically disadvantaged because public education is offered free of tuition. This is a powerful and unique feature of the public school monopoly. Few, if any, typical monopolies have the luxury of offering their products for free and generating income from the government based on the number of people who sign up for their free products. Private schools obviously cannot seriously compete with free tuition, as parents face enormous economic pressure to send their children to public schools. For poor families, there is simply no alternative. For wealthier families, the economic burden is coupled with the knowledge that their tax dollars already pay for public schools. Consequently, private school enrollment is effectively capped, as supply and demand are artificially low for private schools and artificially high for public schools. 
And like most monopolies, the people who are coerced into consuming the public schools' services get stuck with a service that has many undesirable elements. In a competitive market, consumers can choose from different products, selecting the one that matches their tastes and preferences. But a monopoly eliminates that choice, giving consumers only one product that they may or may not like. There is strong evidence that public education is quite undesirable even for families whose children attend the public schools. A 2011 Gallup poll showed that only $34 \%$ of Americans have "a great deal" or "quite a lot" of confidence in their public schools. ${ }^{739}$ Only $8 \%$ of Americans are "completely satisfied" with K-12 education today, and only $37 \%$ are even "somewhat satisfied." 740 These numbers show that consumers of education are not getting the kinds of services that they want. Unsurprisingly, several polls have shown that a strong majority of public school parents would prefer to send their children to private schools if they could afford to do so. ${ }^{741}$ Part of the explanation for these poll numbers could be that public schools are entirely secular, while approximately $80 \%$ of all Americans identify themselves as religious. ${ }^{742}$ In $2009-2010$, only $8 \%$ of all K-12 students attended private religious schools, ${ }^{743}$

\footnotetext{
${ }^{739}$ Near Record-Low Confidence in U.S. Public Schools, GALLuP, July 29, 2011, http://www.gallup.com/poll/148724/Near-Record-Low-Confidence-Public-Schools.aspx.

${ }^{740}$ Education, GALLUP, May 15, 2012, http://www.gallup.com/poll/1612/education.aspx.

${ }^{741}$ See Private Schooling, EDUCATION WEEK, April 4, 2004, http://www.edweek.org/ew/issues/private-schooling/ (citing a Gallup Poll that puts this percentage at 59\%, as well as another study that puts the percentage at 67\%); see also School Choice and Ownership Society, CATO INSTITUTE, http://www.cato.org/special/ownership_society/school-ownership2.html (citing several polls that put support for school vouchers between 49\% and 62\% of Americans); Joy Pullman, Heartlander| Poll: 71 Percent of Moms Support School Choice, FRIEDMAN Foundation, May 9, 2012, http://www.edchoice.org/Newsroom/News/Heartlander---Poll--71-Percent-of-Moms-Support-School-Choice.aspx (finding that $69 \%$ of adults support free access to school vouchers, and that $37 \%$ of the respondents said they would choose to send their children to private schools if given the choice).

${ }^{742}$ See American Religious Identification Survey, Trinity College, available at http://commons.trincoll.edu/aris/files/2011/08/ARIS_Report_2008.pdf, 5 (2008); see also Pew Forum on Religious Life, available at http://religions.pewforum.org/reports (finding that approximately eighty-three percent of Americans identified themselves as religious).

${ }^{743}$ Council for American Private Education, http://www.capenet.org/facts.html (stating that $10 \%$ of all students attend private schools); National Center for Education Statistics, United States Department of Education, "Characteristics of Private Schools in the United States: Results From the 2009-10 Private School Universe Survey," available at http://nces.ed.gov/pubs2011/2011339.pdf, 2, 7 (2011) [Hereinafter "PSS Survey"] (stating that $80 \%$ of private school students attend religious schools).
} 
indicating that consumers of education, $80 \%$ of whom are religious, may not be receiving the kind of education that they want. Alternatively, they could just be upset about the low quality of secular academics or poor school administration. ${ }^{744}$ Either way, people are unhappy with the service that they are consuming.

The experiences of other countries are instructive. When the government does not monopolize the market for education, families often choose to send their children to private schools in substantially higher numbers than they do when the government operates a public school monopoly as in the United States. For instance, in the Netherlands, the government pays for the full cost of education for all students at both public and the private schools. ${ }^{745}$ Consequently, $70 \%$ of school children in the Netherlands attend private schools, with the vast majority attending private religious schools. ${ }^{746}$ In Australia, where the government funds approximately $50-75 \%$ of private school costs, ${ }^{747}$ approximately one-third of all Australian students attend private schools. ${ }^{748}$ In Israel, where the government funds between $60 \%$ and $100 \%$ of private school expenses, $40 \%$ of Israeli students attend private schools. ${ }^{749}$ But in the United States, where the government barely funds private schools at all, only $10 \%$ of students attend

\footnotetext{
${ }^{744}$ A 1998 report comparing math and science performance amongst students from different countries ranked the United States eighteenth, just ahead of Lithuania and Cyprus. See Viteritti, Joseph P. Viteritti, ChOosing EQUALITY: School Choice, The Constitution, ANd Civil Society 4 (1999). See generally Diane RaVitch \& Joseph P. ViteritTi, New Schools FOR A New Century: The REDESIGN OF Urban EdUCATION (1999).

${ }^{745}$ Colin Fraser, The Public School Market in the Netherlands: Money Follows the Child, Frontier Centre for Public Policy, 1-3 (2003).

${ }^{746}$ See Helen F. Ladd, Edward B. Fiske, Nienke Ruijs, Parental Choice in the Netherlands: Growing Concerns about Segregation, 6, prepared for the National Conference on School Choice, Vanderbilt.

University, (September 2009), available at http://www.ncspe.org/publications_files/OP\%20182.pdf.

747 Australian Government, REview of SCHOOL Funding, FinAl RePORT, 15 (December 2011), [hereinafter "Aust. Govt. Rep."] (describing how both government and private schools receive funding from the federal government, local governments, parental fees, and various other private sources).

${ }_{748}$ Jennifer Buckingham, The Rise of Religious Schools, The Centre for Independent Studies, ix (2010), available at http://www.cis.org.au/images/stories/policy-monographs/pm-111.pdf.

${ }^{749}$ Israel Religious Action Center, Education in Israel, http://www.irac.org/IssuePapers.aspx (last visited May 8, 2012) [hereinafter "Israel Religious Action Center"].
} 
private schools. ${ }^{750}$ These statistics show that when families have a meaningful choice, they often choose to send their children to private schools.

Because public schools are insulated from competition, they, like most monopolies, can afford to operate inefficiently and deliver sub-optimal services. The basic reason is that competition forces market players to provide the highest quality services possible at the lowest possible cost. ${ }^{751}$ But a monopoly can afford to slack off and provide lower quality services at a higher expense and just stick the cost back on the consumer. This problem is especially pronounced with public school education because consumers do not choose to pay tuition but are instead forced to cough up taxes to the government. Theoretically, consumers of other monopolized services could still choose whether to buy those services or not. Unsurprisingly, the evils of monopolies are readily apparent to anyone who looks at our public schools. They are wasteful, bloated, bureaucratic monstrosities that fail to effectively educate children. ${ }^{752}$

For poor children, the injurious effects of government's monopoly are especially pronounced. Generally speaking, public schools in poor, urban neighborhoods provide the lowest quality education. ${ }^{753}$ These schools are fraught with crime, dilapidated facilities, and often subpar teachers and administrators. ${ }^{754}$ They consistently produce high drop-out rates, low scores on standardized tests, and few graduates going on to college. ${ }^{755}$ As Justice Thomas put it, "[t]he failure to provide education to poor urban children perpetuates a vicious cycle of poverty,

\footnotetext{
${ }^{750}$ Council for American Private Education, http://www.capenet.org/facts.html (last visited March 21, 2012).

${ }^{751}$ See generally Friedman \& Friedman, supra note 735, at 9-38.

752 See generally JoHn E. CHUBB \& TERRY M. MOE, POLITICS, MARKETS, AND AMERICA'S SCHOOLS (1990) (explaining how public schools' unresponsive bureaucratic structure impairs the quality of education provided). ${ }^{753}$ See Viteritti, supra note 744, at 7 (describing the problems in urban public schools).

${ }^{754}$ See Viteritti, supra note 616, at 167-170 (describing the funding problems and "separate and unequal" status of urban schools).

${ }^{755}$ See Zelman, 536 U.S. at 681-82 (Thomas, J., concurring) (discussing these problems).
} 
dependence, criminality, and alienation that continues for the remainder of their lives.",756 To make matters worse, poor students cannot opt out of this system because they cannot afford to attend private schools and are instead trapped in the jaws of the government's educational monopoly. Their lot in life is truly a sad manifestation of the Court's statement in Brown v. Board of Education: "it is doubtful that any child may reasonably be expected to succeed in life if he is denied the opportunity of an education. ${ }^{757}$ For these reasons, the vast majority of low income parents support private school vouchers. ${ }^{758}$ Even some liberal political theorists hesitantly support vouchers to help poor children. ${ }^{759}$

This economic monopoly also allows the government to exert ideological control over students. As Professor McConnell has pointed out, government control of ideology often has a strong majoritarian bias which in turn tends to smother minority groups and dissenting opinions. ${ }^{760}$ In the nineteenth century, Protestants used the public schools to attack Catholics, and now secularists and liberals use the public schools to attack religion and conservatism. ${ }^{761}$ For this reason, the strongest advocates of vouchers are members of religious minorities, especially Catholics, Evangelicals, and Jews, as well as political conservatives. ${ }^{762}$

\footnotetext{
${ }^{756}$ See Zelman, 536 U.S., at 683 (Thomas, J., concurring).

757347 U.S. at 493 (cited in Zelman, 536 U.S., at 676 (Thomas, J., concurring)).

${ }^{758}$ See T. Moe, SchoOls, Vouchers, AND THE AMERICAN Public 164 (2001) ("The appeal of private schools is especially strong among parents who are low in income, minority, and live in low-performing districts: precisely the parents who are the most disadvantaged under the current system."); Id. at 214 (Table 7-3) (showing support for vouchers is at approximately $75 \%$ for public school parents with incomes under $\$ 20,000,75 \%$ for black public school parents, and $71 \%$ for Hispanic public school parents); see also Viteritti, supra note 744, at 7 (describing support for vouchers amongst the poor and racial minorities); Fried, supra note 731, at 198, n.33 (citing various surveys and articles demonstrating widespread support for vouchers in low income and minority neighborhoods).

${ }^{759}$ See, e.g., Stephen Macedo, Constituting Civil Society: School Vouchers, Religious Nonprofit Organizations, and Liberal Public Values, 75 Chi.-Kent L. Rev. 417 (2000).

${ }^{760}$ See McConnell, supra note 270, at 850-51. ${ }^{761}$ Id.

${ }^{762}$ Douglas Laycock, Why the Supreme Court Changed Its Mind About Government Aid to Religious Institutions: It's A Lot More Than Just Republican Appointments, 2008 B.Y.U. L. Rev. 275, 283-284, 289-290 (2008) (describing historical Jewish support for government aid of religious schools and emerging support amongst Evangelicals).
} 
The government's monopoly of education also disturbs a critical balance of power between the government and parents. Nearly ninety years ago, in Pierce v. Society of Sisters, the Supreme Court recognized that parents, not the state, have the right "to direct the upbringing and education of children" because "[t]he child is not the mere creature of the State." ${ }^{, 763}$ The Supreme Court has time and again reaffirmed that parents have a right to educate their children in the way in which they see fit. ${ }^{764}$ By monopolizing education through the creation of the public schools, the government has created a very uneven playing field that tilts the balance of power firmly towards government schools, substantially decreasing the likelihood that parents will be able to exercise their Society of Sisters rights.

So, why does the education monopoly persist? There are several reasons why it is retained. First, fear and hatred of Catholics has existed since the Nineteenth Century, and Catholic parochial schools have historically comprised the majority of private schools. ${ }^{765}$ AntiCatholic bigotry was most vividly exemplified in the Nineteenth Century school funding wars and in the history of the Blaine Amendments, ${ }^{766}$ and it continued fervently into the Twentieth Century and persists even today. Refusing to fund private schools is an effective way to express anti-Catholic sentiment. Second, some people, especially elites, simply do not like religion of any kind, and they do not want their tax dollars used to support religion in general. ${ }^{767}$ They do not mind, however, using tax dollars obtained from religious people to teach secularism, Darwin, and the joys of extra-marital sex. This view is fueled by growing secularism and by misconceptions about the supposed need to maintain a "wall of separation between church and

\footnotetext{
763 Society of Sisters, 268 U.S. at 534-535.

${ }^{764}$ See, e.g., Meyer, 262 U.S. 390; Yoder, 406 U.S. 205.

${ }^{765}$ In 2009-2010, the percentage of private school students attending Catholic schools dropped to 42.8\%, down from 54.5\% in 1989-1990, http://www.capenet.org/facts.html, and 95\% in 1961. Laycock, supra note 708, at 282.

${ }^{766}$ See supra Part V.A..

${ }^{767}$ See Viteritti, supra note 616, at 180 (describing the secular philosophy of John Dewey, Dewey's goal of eliminating religion from schools, and Dewey's impact on the Twentieth century).
} 
state."768 Third, many individuals and organizations, namely teachers unions, school boards, administrators, and all other school personnel, benefit from a massive government-run school system, and they do not want to lose their jobs or give up their monopoly rents. ${ }^{769}$ The beneficiaries of a government grant of monopoly often wield substantial political influence and are able to sway elected officials to preserve their monopoly at all costs. ${ }^{770}$ Fourth, some wealthier communities are concerned that local tax revenues would be diverted away from schools in their communities. ${ }^{771}$ Some of these individuals also fear that poor, minority students from the inner city could start attending schools in their communities. Indeed the Ohio voucher plan from Zelman allowed inner city children to enroll in suburban public schools, if those schools would permit them to enroll, but no suburban public schools allowed them to attend. ${ }^{772}$

\footnotetext{
${ }^{768}$ The Supreme Court first cited this famous quote from Thomas Jefferson in See Everson, 330 U.S. at 15-16. Ironically, the holding in Everson actually permitted aid to religious schools. Id. at 17-18. And public funds have long been used to support religious hospitals, colleges, as well as religious organizations involved in community development, housing, and other charitable purposes. See, e.g., Zelman, 536 U.S., at 667 (O'Connor, J., concurring) (discussing federal funding of higher education amongst others); Bradfield v. Roberts, 175 U.S. 291, 299-300 (1899) (permitting funding of religious hospitals); Bowen v. Kendrick, 487 U.S. 589, 617-18 (1988) (allowing funding of religious charities); Quick Bear v. Leupp, 210 U.S. 50, 81-82 (1908) (permitting the federal government to administer a trust fund for Native Americans that used tribal money to support religious schools); See also Natasha Mulleneaux, The Failure To Provide Adequate Higher Education Tax Incentives for Lower-Income Individuals, 14 Akron Tax J. 27, 30-31 (1999). Also note that the court in Everson actually misquotes Jefferson because the court claims that Jefferson's wall exists only as a result of the Establishment Clause. Jefferson actually referenced both the Establishment and Free Exercise Clauses. See 16 JEFFERSON'S WORKS 281 (Monticello ed.1903) ("I contemplate with sovereign reverence that act of the whole American people which declared that their legislature should 'make no law respecting an establishment of religion, or prohibiting the free exercise thereof,' thus building a wall of separation between Church \& State") (emphasis added). Jefferson thus said that both clauses were responsible for creating the wall of separation - the Free Exercise Clause just as much as the Establishment Clause. Jefferson was actually praising the way in which the First Amendment protected religion by keeping government away from it. ${ }^{769}$ See, e.g., Paul T. Hill, The Supply-Side of School Choice, at 140, 144-47, in SCHOOL CHOICE AND SOCIAL CONTROVERSY, IN SCHOOL CHOICE AND SOCIAL CONTROVERSY (Stephen D. Sugarman \& Frank R. Kemerer eds., 1999) (discussing the development of the public school bureaucracy); MARK SCHNEIDER ET AL., CHOOSING SCHOOLS: CONSUMER CHOICE AND THE QUALITY OF AMERICAN SCHOOLS 33 (2000) (discussing the growth and increased complexity of the public school bureaucracy in the Twentieth century); see also Chubb \& Moe, supra note 698 (strongly criticizing teachers unions for their opposition to vouchers).

${ }^{770}$ See Calabresi \& Price, supra note 730, at 56-57 (describing this concern with the railroads at the end of the nineteenth century).

${ }^{771}$ See Fried, supra note 731, at 169, n.22 (discussing this form of opposition).

${ }^{772} I d$.
} 
The fact that the government is the beneficiary of the monopoly does not alleviate the Fourteenth Amendment violation. President Jackson vetoed the re-charter of the Second National Bank, which was partially owned by the federal government, on the ground that it gave monopoly banking privileges to a single federally chartered corporation. And the public schools fit the basic model of a special monopoly because they single out a class of people for a special benefit and consequently burden all other classes of people. ${ }^{773}$ Jackson himself decried laws that sought "to grant titles, gratuities, and exclusive privileges, to make the rich richer and the potent more powerful." 774 But public schools do just that, perpetuating themselves through their statutory power over taxpayers and exerting their ideological control over religious dissenters.

\section{The Solution: Endorse Pluralism}

To rectify the way in which the public schools breach the Fourteenth Amendment both by discriminating on the basis of religion and by establishing a monopoly which does not promote the general good of the whole people, the Supreme Court should order state governments to make education vouchers available to any student who wants a private education either secular or religious. If families choose to send their children to private schools, whether secular or religious, the government should fund that education, just as it funds public school educations today. The Supreme Court would not have to change its case law banning direct funding of religious education by the public schools, and it could instead simply require the states to implement voucher programs with the vouchers being redeemable at secular or religious schools based on the parents' choice. The Supreme Court should not shy away from the fact that judicially mandated vouchers would cause a significant, perhaps revolutionary, change in American public school education. In Brown v. Board of Education, the Supreme Court radically

\footnotetext{
${ }^{773}$ See LAWRENCE FrEDERICK KOHL, THE POLITICS OF INDIVIDUALISM: PARTIES AND THE AMERICAN CHARACTER IN THE JACKSONIAN ERA 61-62 (1989) (discussing Jacksonian fears of corporations, central banking, and monopolies).

${ }^{774}$ Pole, supra note 168, at 145 (quoting Jackson); Yudof, supra note 21, at 1376.
} 
changed American public schools forever and for the better, by tearing down an educational system that discriminated based on race. The Supreme Court should be similarly enthusiastic about striking down our present-day public school system that discriminates on the basis of religion and that functions as a government-granted monopoly.

Forcing the states to implement education voucher programs is not a revolutionary idea. Embedded in the philosophy of government vouchers to pay for school education is the principle of pluralism which is a foundational democratic value that permeates our whole constitutional system. For example, constitutional federalism recognizes that the fifty states might have varying values, tastes, and concerns; the electoral process recognizes that different people might vote for different leaders; and the First Amendment acknowledges that individuals might have different opinions and religious affiliations. Similarly, government funding of private school education recognizes that families might have different approaches to education. Frederick Douglass once said that, "education ... means emancipation. It means light and liberty. It means the uplifting of the soul of man into the glorious light of truth, the light by which men can only be made free.",775 How can there be only one kind of educational "light and liberty?" The notion that the best way to achieve Douglass' "light and liberty" is through a government-run secular school system with an environment hostile to religion is absolutely preposterous. There are many ways to educate children, and many different kinds of plausible schools. Instead of pursuing the impossible task of defining a set of common, neutral values to thrust upon all children, ${ }^{776}$ the government should instead embrace pluralism and recognize that different people have different values. Favoring public secular education over private religious education is the pinnacle of intolerance and contradicts democratic principles.

\footnotetext{
775 The Blessings of Liberty and Education: An Address Delivered in Manassas, Virginia, on 3 September 1894 , in 5 THE FrederiCK Douglass PAPERS 623 (J. Blassingame \& J. McKivigan eds. 1992).

${ }^{776}$ Sherry, supra note 676, at 156-182 (discussing the difficulty of finding common, neutral educational values).
} 
Many other democratic countries have rejected the American "one size fits all" model

and have instead endorsed a pluralistic model that requires the government to fund private religious education. Some of those countries include Australia, Belgium, Canada, Denmark, Germany, Iceland, Israel, the Netherlands, Scotland, Spain, Sweden, and New Zealand, ${ }^{777}$ England, and France, ${ }^{778}$ amongst others. ${ }^{779}$ Many of these countries are religiously diverse ${ }^{780}$ and choose to fund religion as a means of embracing and celebrating their diversity. The American system with its hostility to religious education stands out as a complete anomaly.

Comparing and contrasting the American experience with the Dutch experience highlights just how disgraceful the American system of public school education is. In the nineteenth century, both the Netherlands and the United States recognized that education was fundamentally important. ${ }^{781}$ And during that time, both countries faced enormous turmoil over how to fund education. ${ }^{782}$ In the United States, the conflict featured Protestants against Catholics; in the Netherlands, secular liberals faced off against Catholics and other Christians. American

\footnotetext{
777 Joseph P. Viteritti, A Truly Living Constitution: Why Educational Opportunity Trumps Strict Separation on the Voucher Question, 57 N.Y.U. Ann. Surv. Am. L. 89, 112 n.127 (2000).

778 See Zelman, 536 U.S., at 663 (Breyer, J., dissenting).

${ }^{779}$ See Charles GLenN \& JAN DE GroOF, Finding THE Right BALANCE: FreEdom, AutonOMY AND ACCOUNTABILITY IN EDUCATION (2002) (reviewing education in twenty-eight countries or communities).

${ }^{780}$ In Canada, $44 \%$ of the population is Catholic, $29 \%$ is Protestant, $11 \%$ belongs to other religions, and $16 \%$ have no religious affiliation. U.S. DEPARTMENT OF STATE, http://www.state.gov/j/drl/rls/irf/2010_5/168201.htm. In the Netherlands, approximately $29 \%$ of the population is Catholic, $19 \%$ is Protestant, $10 \%$ belongs to other religions, and $42 \%$ have no religious affiliation. U.S. DEPARTMENT OF STATE, http://www.state.gov/j/drl/rls/irf/2010 5/168329.htm. And in Israel, although three-quarters of the population is Jewish, the differences in religious observance and belief are so vast that the sub-groups might as well be members of different religions. U.S. DEPARTMENT OF STATE, http://www.state.gov/j/drl/rls/irf/2010 5/168266.htm. Seventeen percent of Israeli Jews are Orthodox, 39\% are "traditional," and 44\% are secular. The other quarter of Israel's population is composed of Muslims, Christians, and other denominations. Australia, England, and France are similarly diverse. See U.S. DEPARTMENT OF STATE, http://www.state.gov/j/drl/rls/irf/2010_5/.

${ }^{781}$ In 1868, thirty-six out of thirty-eight American states had provisions in their constitutions requiring their state governments to provide a public education. Calabresi \& Agudo, supra note 37, at 108. The Dutch Constitution of 1848 explicitly granted individuals and organizations the right to set up private schools according to their convictions and without governmental interference. Fraser, supra note 745, at 1-2 (describing how the Dutch Constitution created freedom to establish schools, freedom of conviction, and freedom of organization).

${ }^{782}$ See supra Part V.A. (describing this history in the United States); see Monsma \& Soper, Supra note 710, at 55-57 (describing this history in the Netherlands).
} 
Protestants and Dutch secularists each controlled their respective public school systems and sought to teach children an allegedly consensus set of values that would unify society. In both countries public education turned out to be quite oppressive for religious minorities who did not subscribe to the majoritarian ideology. And so in both countries, religious minorities, mainly Catholics, objected to the educational systems and fought to obtain public funds for their private schools. But the outcomes were vastly different. Dutch Catholics joined forces with Orthodox Reformed groups and successfully obtained school funding from the Dutch government, while American Catholics got steamrolled by the Protestant majority and by today's secular elite.

The two countries' disparate philosophies are striking. The Netherlands adopted the political philosophy of Abraham Kuyper, a Calvinist, who believed that tolerance and diversity whether secular or religious - were crucial elements of a successful society. ${ }^{783}$ Kuyper rejected the notion of a single set of universal values or that one value system was necessarily better than another. Instead Kuyper favored pluralism and tolerance. So widely accepted was Kuyper that he served as Prime Minister of the Netherlands from 1901-1905. In 1917, the Dutch Constitution was amended to guarantee funding equality for public and private schools without regard to religious affiliation. ${ }^{784}$ Kuyper's pluralism was officially constitutionalized and has continued to play a central role in Dutch society since that time. In contrast, nineteenth century Americans endorsed religious intolerance and passed Blaine Amendments. ${ }^{785}$ Through the mid-twentieth

\footnotetext{
${ }^{783}$ Id., at 57-59.

${ }^{784}$ Id., at 57. The current Constitution reads,

(5) The standards required of schools financed either in part or in full from public funds shall be regulated by Act of Parliament, with due regard, in the case of private schools, to the freedom to provide education according to religious or other belief . . .

(7) Private primary schools that satisfy the conditions laid down by Act of Parliament shall be financed from public funds according to the same standards as public-authority schools. The conditions under which private secondary education and pre-university education shall receive contributions from public funds shall be laid down by Act of Parliament.
}

NETH. CONST. ch. 1 art. 23.

785 See supra Part V.A. 
century, Protestant themes and anti-Catholic bigotry pervaded American public schools. Starting in the 1960s, the Supreme Court struck back at Protestants and began eradicating all religion from public schools. Contemporary public school ideology has mutated into a mishmash of secularism, liberalism, and environmentalism. ${ }^{786}$ Religious families are left to fend for themselves. At a time when the Dutch were endorsing pluralism, Americans were endorsing intolerance.

The fruits of these disparate philosophies are evident in contemporary education. Today Dutch children can attend the school of their choice, and the Dutch government pays the full cost whether the school is religious or secular, public or private. Consequently, $70 \%$ of Dutch children attend private schools, with the vast majority attending private religious schools. ${ }^{787}$ But in the United States, only $8 \%$ of children attend private religious schools, even though approximately $80 \%$ of Americans identify themselves as religious. ${ }^{788}$ In the context of education, the Dutch embraced Fourteenth Amendment principles, but Americans did not.

A voucher system would dramatically change American schools for the better. ${ }^{789}$ Vouchers would break up government's education monopoly by giving students, particularly poor students, the ability to attend private schools. ${ }^{790}$ Students would thus enjoy all the benefits of a free market, including more ideological and religious choices and greater quality

\footnotetext{
786 See Robert H. Nelson, Rethinking Church and State: The Case of Environmental Religion, 29 Pace Envtl. L. Rev. 121 (2011) (arguing that environmentalism is a religion).

${ }^{787}$ See Helen F. Ladd, Edward B. Fiske, Nienke Ruijs, Parental Choice in the Netherlands: Growing Concerns about Segregation, 6, prepared for the National Conference on School Choice, Vanderbilt.

University, (September 2009), available at http://www.ncspe.org/publications_files/OP\%20182.pdf.

${ }^{788}$ See American Religious Identification Survey, Trinity College, available at http://commons.trincoll.edu/aris/files/2011/08/ARIS_Report_2008.pdf, 5 (2008); see also Pew Forum on Religious Life, available at http://religions.pewforum.org/reports (finding that approximately eighty-three percent of Americans identified themselves as religious).

${ }^{789}$ See generally Friedman \& Friedman, supra note supra note 735.

790 See Joseph P. Viteritti, Reading Zelman: The Triumph of Pluralism, and Its Effects on Liberty, Equality, and Choice, 76 S. Cal. L. Rev. 1105, 1172-73 (2003) (discussing how vouchers would benefit the poor).
} 
education. ${ }^{791}$ Public schools themselves might even benefit from the increased competition which could motivate them to operate more efficiently and improve the quality of education delivered. ${ }^{792}$ The result would be greater pluralism, more diversity, enhanced religious freedom, and higher quality education.

\section{Conclusion}

After the Civil War, Americans amended the Constitution to guarantee equality for all people by eradicating systems of caste and class legislation. They did this because they had learned from their own mistakes - slavery, government-granted monopolies, and the like. They observed caste systems around the world from the Indian Caste system to European feudalism, and they recognized that it was fundamentally immoral to single out specific groups for special burdens or benefits that did not apply to the rest of society. Although limited bans on class legislation had been around since the founding, after the Civil War the sentiment was that society had changed to the point where a ban on class legislation had to be constitutionalized. From then on, legislation would have to provide a general welfare benefit, and the laws would have to be equally enforced. No longer could the government pick out winners and losers. The goal was a society of equals. Religion was certainly included in this protection. At this point in history, the United States stood out on the world stage as the standard-bearer for societal equality.

Unfortunately, the Fourteenth Amendment's goal of creating a society without systems of class, caste, or government conferred monopolies did not come to fruition quickly. Racist legislation and enforcement continued. Segregation persisted. Blaine Amendments were passed.

\footnotetext{
${ }^{791}$ Out of ten empirical studies evaluating the impact of vouchers on student performance, nine showed that student performance improved and only one showed no impact. See Greg Forster, A Win-Win Solution: The Empirical Evidence on School Vouchers, THE FOUNDATION FOR EDUCATIONAL CHOICE (March 2011), available at http://www.edchoice.org/CMSModules/EdChoice/FileLibrary/656/A-Win-Win-Solution---The-Empirical-Evidenceon-School-Vouchers.pdf.

${ }^{792}$ Out of nineteen empirical studies evaluating the impact of vouchers on public schools, eighteen showed that public schools improved and only one showed no impact. Id.
} 
Even after the adoption of the Nineteenth Amendment in 1920, gender discrimination lived on until 1971. In short, American legislatures got away with a lot of racist and sexist legislation, and the courts until Brown v. Board of Education failed to step in. Our history of Jim Crow and of sexism does not prove that the original meaning of the Fourteenth Amendment permitted racism and sexism. They only prove that the American people and their Supreme Court justices were not adhering faithfully to the Fourteenth Amendment's ban on racial and gender systems of class legislation and of caste. The fact that some people violate a law does not mean that the law permits the conduct in question. It just means that some people are engaged in lawlessness. Over time, American courts and legislatures have rectified many of the lawless violations of the Fourteenth Amendment, eliminating racial and gender discrimination, as well as other improper forms of class legislation. But as for discrimination on the basis of religion, American courts and legislatures still have significant work ahead.

In the context of construing the Free Exercise Clause of the First Amendment, government currently has way too much discretion to force religious individuals to comply with generally applicable laws. Smith and City of Boerne represented significant steps away from the no class legislation principles of the Fourteenth Amendment. We think the Sherbert-Yoder balancing approach should be restored, albeit with a bit more backbone, and the various state Blaine Amendments should be struck down because they discriminate on the basis of religion. In the context of education, the situation is truly embarrassing. While the United States was once at the forefront of the equal rights movement back in the Eighteenth and Nineteenth Centuries, the current state of the American public schools has unfortunately moved the United States to the back of the pack. Countries all over the world have endorsed educational pluralism, the funding religious education, and private schools of all stripes. But the United States 
persistently maintains an educational monopoly that favors secular education and secularism in general. The funding scheme grossly discriminates against religious families and ultimately diminishes the quality of education and educational choices for children. Most astonishingly, many states still have Blaine Amendments which facially discriminate against religion. The result is that the equality goals of the Fourteenth Amendment remain unrealized for religious families who are forced to pay for both public and private schools. And the assurance of Pierce v. Society of Sisters that everyone has a right to educate their children as they see fit remains an unfulfilled promise for many families who are coerced into sending their children to militantly secular public schools. Courts and legislatures should return to the principles of the Fourteenth Amendment and should endorse religious pluralism by requiring the states to implement voucher systems for both secular and religious public and private schools. 